$$
\begin{aligned}
& \text { (200) } \\
& \text { Rə45 } \\
& 110.76-56 \\
& \text { Peat.c 1:M(2:1:44 } \\
& \text { ग्र3.0 }
\end{aligned}
$$

MINERAL RESOURCES OF ELKO COUNTY, NEVADA

By

Roscoe M. Smith

Prepared in cooperation with

Nevada Bureau of Mines and Geology
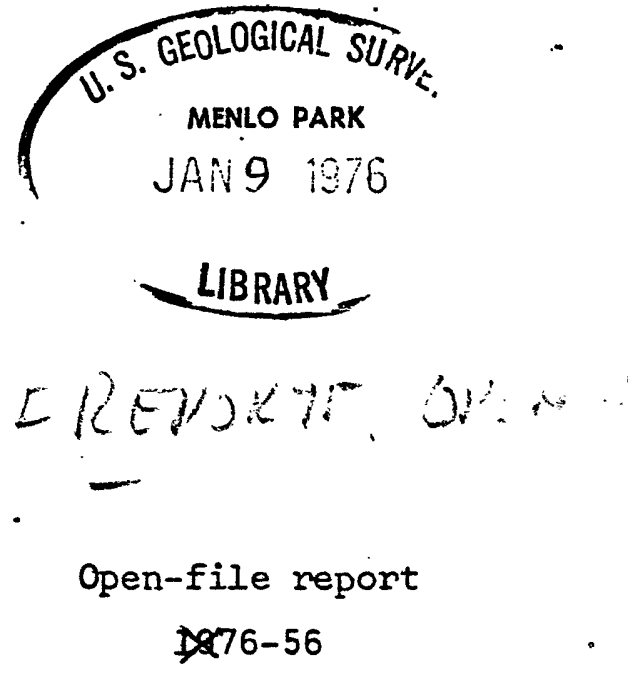

Peiefit: $\because$

This report is preliminary and has not been edited or reviewed for conformity with Geological Survey standards 


\section{Contents}

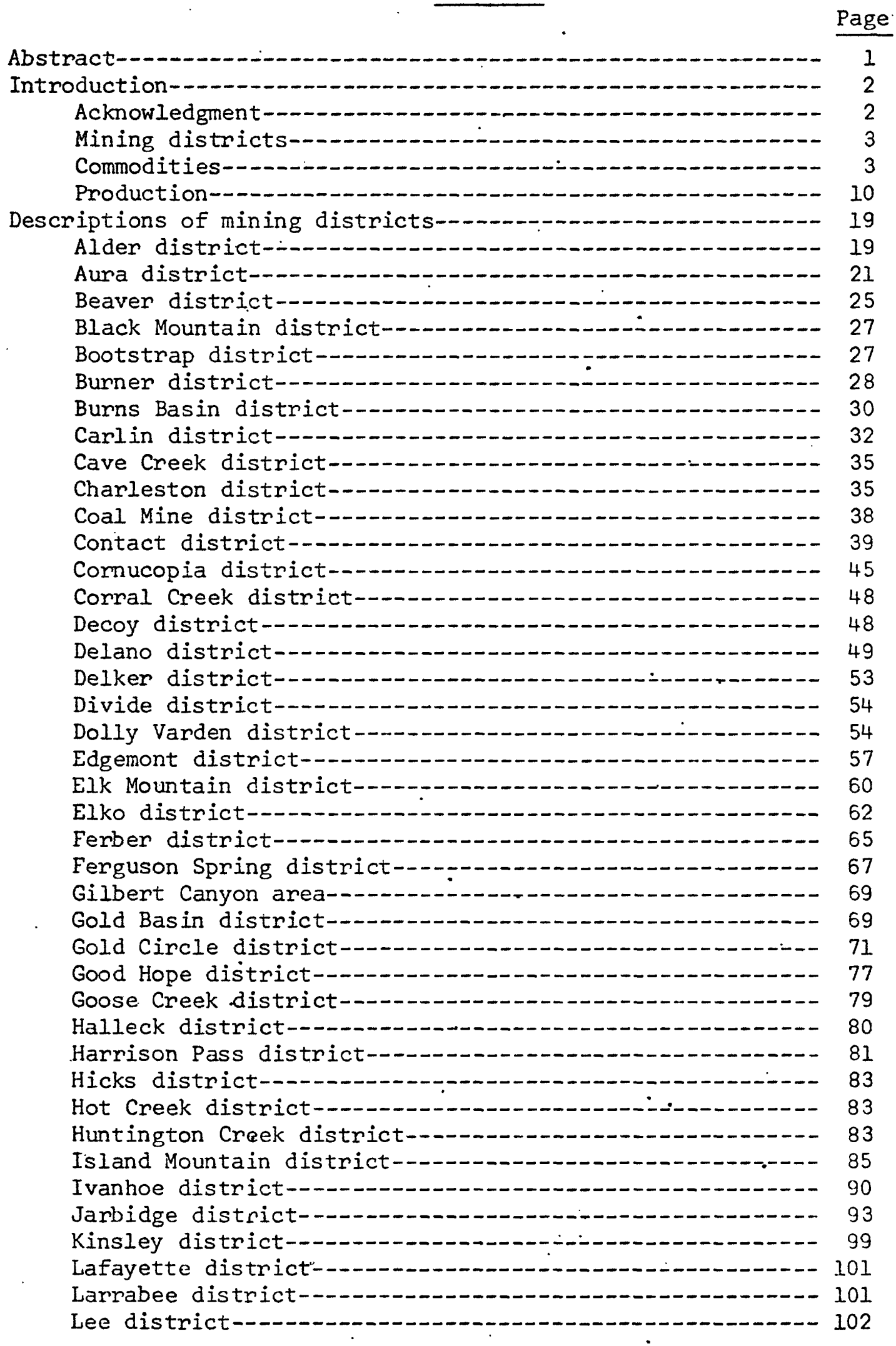


Descriptions of mining districts--continued

Lime Mountain district_. 104

Loray district-_- 106

Lucin district-_._. 108

Mernimac district-_._._.

Montello phosphate area-_-_-_ 115

Moor district-_._. 115

Mountain City district-_._.

Mud Springs district_-_._. 128

Pequop phosphate area-_. 130

Pilot Peak district-_._. 133

Proctor district-_. 133

Railroad district-_._- 135

Robinson Mountain district-_... 143

Rock Creek district-_-_-_ 143

Ruby Mountain Range district_-_._._. 145

Ruby Range district_-_._._. 145

Ruby Valley district-_... 148

Spruce Mountain district_-_._._. 151

Swales Mountain district_-_._._._. 153

Tecoma district-_-_-_-_- 158

Tuscarora district_-_._. 160

Union district-_. 167

Valley View district_._. 168

Warm Creek district_-_._._._. 171

Wells district-_.

Wendover district__._. 175

White Horse district-_._- 175

Guide to exploration--_- 177

Selected references-_-_-_.

Appendix (Explanation-Plate 1) 194

IIlustrations

Plate 1. Mineral resources map of Elko County.

Figure 1. Index map of mining districts-_- 4

2. Exploratory oil wells-_- 8

3. Geothermal land classification-................. Il

Table 1. Index of mining districts- Tables

2. Exploratory drill holes for petroleum, through 19739

3. Temperatures of some Elko County hot springs-.-.-- 12

4. Distribution of mineral deposits by district.....- 13

5. Production of mining districts through 1969-...-.- 14

6. Recorded annual production of ores, 1859-1969-...- 16 
Tables 7-54. Mining districts, mines through 1969.

\begin{tabular}{|c|c|c|}
\hline & & \\
\hline . & Aura & 23 \\
\hline & Beaver-- & 26 \\
\hline & Bootstrap-- & 29 \\
\hline 11. & Burns Bas in- & 31 \\
\hline & Carlin-..--.. & 34 \\
\hline 13. & Charleston--- & 37 \\
\hline & Contact--.-- & 40 \\
\hline & Cornucopia--- & 46 \\
\hline & Delano-...-.. & 51 \\
\hline & Dolly Varden- & 56 \\
\hline 18. & Edgemont--.-- & 58 \\
\hline & Elk Mountain- & 61 \\
\hline 20. & Elko-_....... & 64 \\
\hline 21. & Ferber-.--..- & 66 \\
\hline 22. & Ferguson Sprir & 68 \\
\hline 23. & Gold Basin--. & 70 \\
\hline & Gold Circle-- & 73 \\
\hline 25. & Good Hope--- - & 78 \\
\hline 26. & Harrison Pass & 82 \\
\hline 27. & Hicks--- & 84 \\
\hline 28. & Island Mountai & 87 \\
\hline 29. & I vanhoe--.--- & 91 \\
\hline 30 . & Jarbidge----- & 95 \\
\hline 31. & Kinsley-...-. & 100 \\
\hline 32 . & Lee-- - - & 103 \\
\hline 33. & Lime Mountain & 105 \\
\hline & Loray--...-.-. & 107 \\
\hline 35. & Lucin-_....... & 109 \\
\hline 36. & Merrimac-_-_- & 113 \\
\hline 37. & Mountain City- & 119 \\
\hline 38. & Mud Springs-- & 129 \\
\hline 39: & Pilot Peak--- & 134 \\
\hline 40. & Proctor-..-- & 136 \\
\hline $4 i$. & Railroad---- & 140 \\
\hline 42. & Rock Creek--- & 144 \\
\hline 43. & Ruby Mountain & 146 \\
\hline 44. & - & 147 \\
\hline 45. & Ruby Valley--- & 149 \\
\hline 46. & Spruce :ountai & 154 \\
\hline 47. & 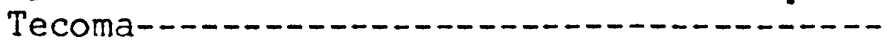 & 159 \\
\hline 48. & Tuscarora-- & 163 \\
\hline 49. & Valley View- & 170 \\
\hline 50 . & $\cdots$ & 172 \\
\hline 51. & Wells---.-- & 174 \\
\hline 52. & Wendover.-... & 176 \\
\hline & White Horse-- & 178 \\
\hline & Unknown--..-- & 179 \\
\hline
\end{tabular}




\title{
MINERAL RESOURCES OF. ELKO COUNTY, NEVADA
}

\author{
By Roscoe M. Smith
}

\begin{abstract}
Of the $E .6$ named mining districts in Elko County, 56 have been productive of one or more of 19 different commodities: Il metals--copper, gold, silver, lead, zinc, mercury, tungsten, manganese, iron, uranium, and antimony; 8 nonmetals--sand and gravel, stone, barite, diatomite, gems, oil shale, volcanic ash, and clay. In addition to the commodities produced, at least 5 others--beryllium, molybdenum, tin, phosphorite, and petroleum, occur in amounts sufficient to warrant exploration. The other districts have been explored, but no production has been recorded.

Total value-when-sold of production recorded through 1969 was nearly $\$ 91$ milion; actual production was considerably greater, especially if sand and gravel, barite, and other nonmetallic products before 1953 are included. In value of metals produced, the five highest districts are Mountain City ( $\$ 26$ million), Tuscarora ( $\$ 11$ million), Jarbidge ( $\$ 10$ million), Aura ( $\$ 6$ million), and Railroad (nearly $\$ 5$ million). The Rio Tinto copper mine in the Mountain City district yielded $\$ 21$ million. Of the 17 districts that produced nonmetaliic minerals, Bootstrap is the largest producer, containing the Rossi mine, one of the two largest barite mines in the United States.

Most of the metals produced came from veins and replacement deposits in limestone or dolomite near granitic stocks; exceptions are manganese and mercury, which are not associated with known or inferred stocks; mercury is further excepted because it occurs in volcanic rocks, as do a few deposits of the major metals. The largest deposit--the Rio Tinto lode-was a combination of fissure filling and replacement along a beddingplane shear zone $150 \mathrm{ft}$ wide and 1,200 ft long in carbonaceous shale of the Valmy Formation; this deposit is apparently older than the lountain City stock and its mineralization may be related to Paleozoic mafic volcanism: later than a major thrust fault, inferred to underlie the area at a depth of about 5,000 ft.

Most of the nonmetallic minerals mined were sedimentary bedded deposits, but mica was mined from pegmatite deposits, and turquoise from both placer and hydrothermal deposits.

The largest known reserves of metals (1973) are of porphyry copper in the Dolly Varden district and gold in the Bootstrap district. Reserves of barite also are presumed to be large.
\end{abstract}


The greatest potential for future production of metals, notably copper and gold, appears to be in the known districts or extensions of them and peripheral to deposits that are related to known or concealed plutons and thrust faults. Potential resources in deposits too low in grade to be worked profitably at the present time include all commodities that have been produced and, in addition, known. deposits of beryllium, molybdenum, tin, and phosphorite. Speculative resources in undiscovered deposits may reasonably be predicted to include all known commodities as well as others that are unsuspected. Petroleum may yet be produced from the Elko Formation and geothermal energy from the Ruby Valley and Elko areas.

\section{INTRODUCTION}

Mineral deposits in Elko County were described in Nevada Bureau of Mines Bulletin 54 (Granger and others, 1957), which included descriptions of individual mines in the princizal mining districts. As that bulletin is available in most university and large public libraries, mine descriptions are omitted here except for the Rio Tinto mine in the Mountain City district, for which supplementary data are now available.

The purpose of this report is to provide an inventory of all mining districts in the county and, for each district, to indicate its currently known extent, to list the names of all mines for which production is recorded, and to summarize the geclogic setting as it relates to ore controls. The inventory includes several small and old districts not included in former lists.

\section{Acknowledgments}

I am indebted to other U.S. Geological Survey geologists for the in frequent consultations and information on the geology of most of the mining districts and to the many authors whose names appear in the list of references for the publications from wirich much of this report was compiled. Members of the staff of Nevada Bureau of Mines and Geology reviewed the manuscript; their many helpful suggestions are gratefully acknowledged.

The earliest published reports on mining in Elko County, other than articles in newspapers and trade magazines, are those of the Nevada State Mineralogist, which cover only the years 1866 through 1878 (the area was a part of Lander County before March 5, 1869). Those reports were combined and condensed by Myron Angel, and the summaries included in History of the State of Nevada, published by Thompson and West ( 1881 , reproduced by HowellNorth Press in 1958). Of many suisequent reports, one by Emmons (1910) and one by Hill (1916), together with annual volumes of the Mineral Resources (U.S. Geol. Survey) and Minerals Yearbook (U.S. Bur. Mines, 1925-32), are the main sources of compilations by Lincoln (1923) and Granger and others (1957).

Since Bulletin 54 was publisied, many geologic reports and maps on individual districts and areas have been completed; they are referenced where appropriate in the text of this bulletin. 
The names of mining districts were compiled from records of the County Recorder at Elko, from those of the Bureau of Land Management (Iand Office) in Reno, and a few others from data in the references cited.

Locations of many of the mines are shown on topographic maps of the U.S. Geological Survey; others on maps of individual districts.

For the lists of productive mines. in the county, I am indebted to Roy Ashizawa, formerly of the Statistical Division, U.S. Bureau of Mines.

Residents of Elko County were unfailingly generous of their time and information during the course of the fieldwork.

I especially wish to acknowledge the reviews of E. C. Stephens, former geologist of the Rio Tinto mine, of the section of this report on the Mountain City district, and by R. A. Gulbrandsen, U.S. Geological Survey, who contributed to the sections on phosphates.

\section{Mining districts}

Mining districts, as they were first established, were not restricted by boundary lines, since the full areal extent of mineralization is rarely known. In this report, as a convenience to the reader, they are delineated by townships and sections: the arbitrary boundaries of the 66 districts shown on figure $l$ and plate $l$ approximate the extent of mineralization as it is now known.

Most mining districts have Deen known by different names at different times. The various names found in the literature and in production records are indexed in table 1; names currently in use are those in bold-faced type.

\section{Commodities}

Natural resources of Elko County include 32 mineral commodities as well as large amounts of sand and gravel, substantial water resources, and potential resources of petroleum and geothermal energy. Of the 32 mineral commodities, 19 have been produced commercially. Small or low-grade deposits of the 13 others have been discovered, 5 of them (beryllium, molybdenum, tin, phosphorite, petroleum) in amounts large enough to warrant exploration.

Sand and gravel deposits are not inventoried in this report. They are plentiful throughout the county but most of them are outside the mining districts.

Water is defined as a mineral, but water resources are not included in this report because estimates are not available for many of the valleys.

Petroleum, although not a mineral, is part of. what is often called the Mineral Kingdom, so a summary is included herein. Exploratory oil wells drilled before 1974 are listed in table 2; they are shown on figure 2 and plate 1. 


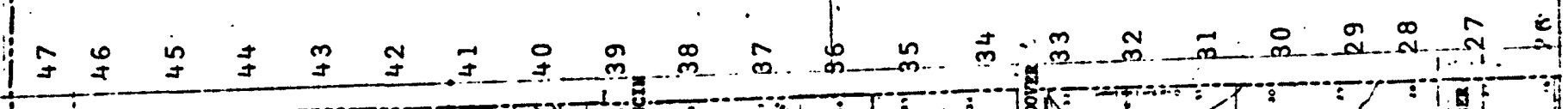

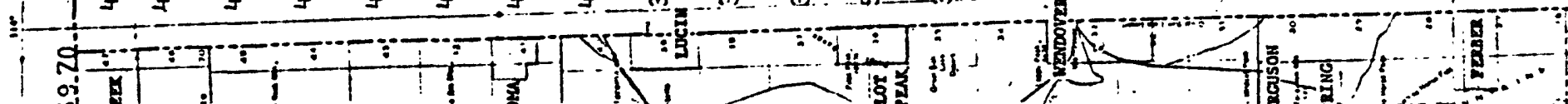

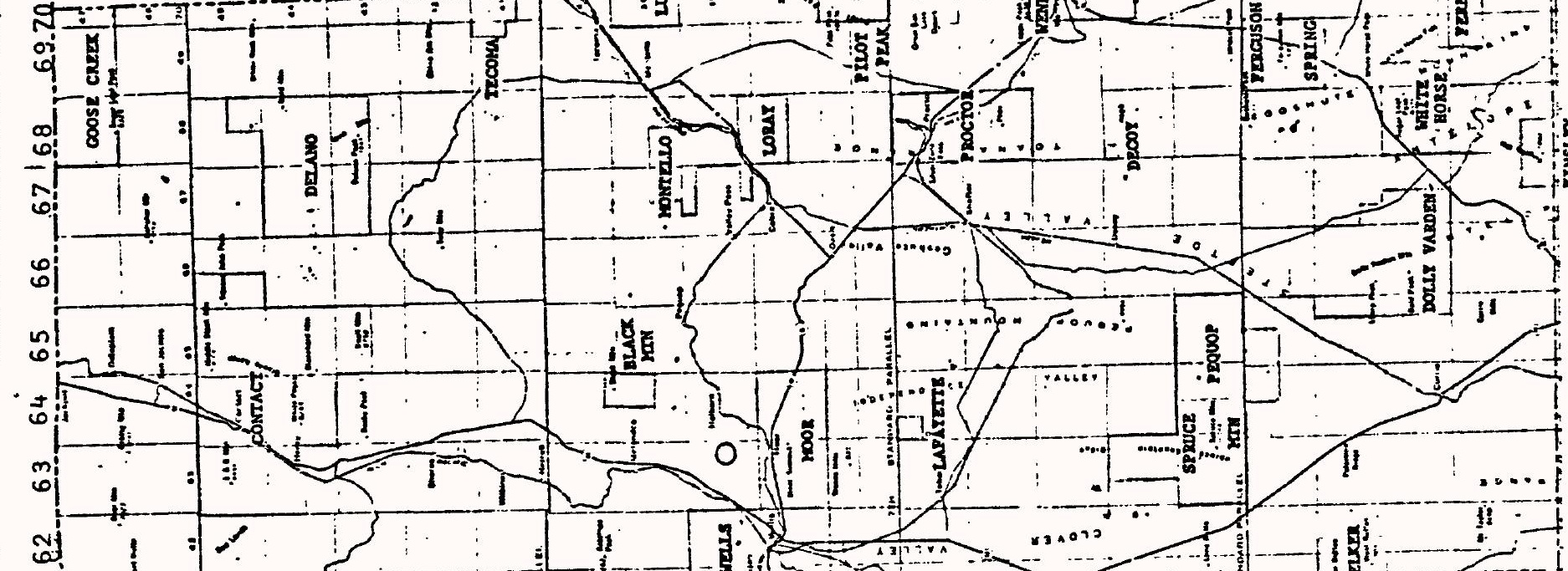
$=a_{0}$ of in] जी 至

की
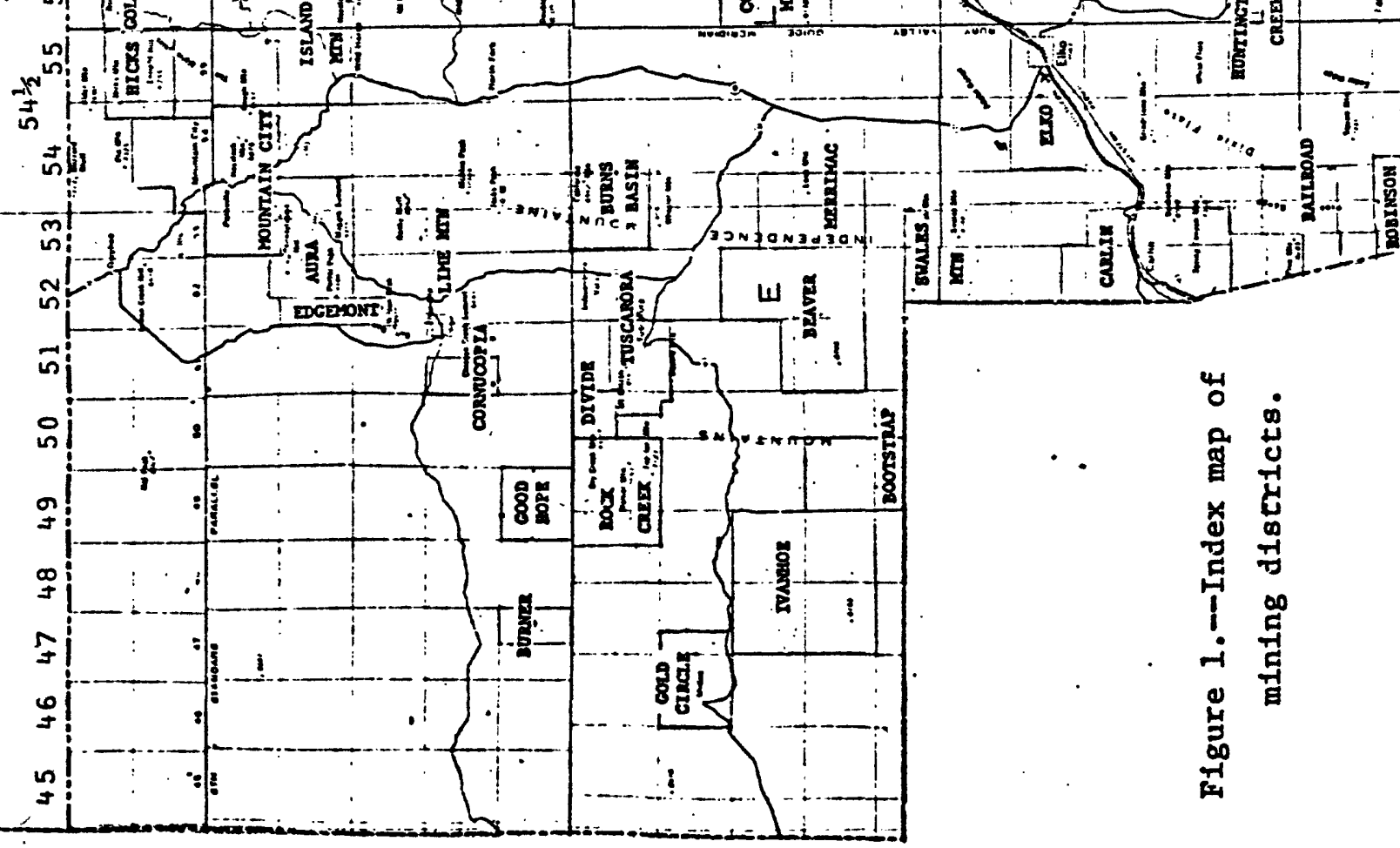

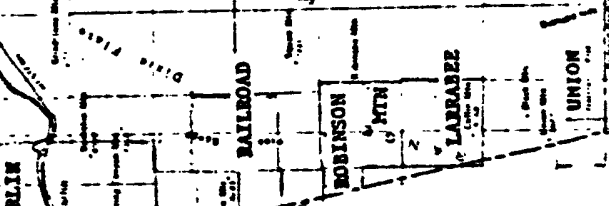
W I I I I 
Table 1.--Index of mining districts, Elko County, Nev.

Adobe Range - see Coal Mine

Alabama - see Contact

Alder (Tennessee Mountain, Tennessee Gulch)

Allegheny (Alleghany) - see Ferguson Spring

Amazon - see Good Hope

Antelope - see Kinsley

Aura (Bull Run, Centennial, Columbia, Blue Jacket, Cope)

Aurora - see Good Hope

Battle Mountain - see Ivanhoe

Beaver

Black Forest - see Spruce Mountain

Black Mounta in

Blue Jacket - see Aura

Bootstrap (Boulder Creek)

Boulder Creek - see Bootstrap

Bruneau (Wyoming, Bruno) - see Charleston

Buell - see Lucin

Bullion - see Railroad

Bull Run - see Aura

Burner (Burner Hills)

Burns Basin

Butte Valley - see Mud Springs

Carl in

Castle Park - see Loray

Cave Creek

Centennial - see Aura, Edgemont

Charleston (Copper Mountain, Cornwall Basin, Wyoming, Bruneau, Mardis)

Clover Valley - see Warm Creek.

Coal Mine (Coal Canyon)

Cobre section - see Loray

Columbia - see Aura

Contact (Kit Carson, Salmon, Salmon River, Porter, Alabama)

Cope - see Mountain City, Aura

Copper Canyon - see. Robinson Mountain

Copper Mountain - see Charleston

Cornucopia

Cornwall Basin - see Charleston

Corral Creek (Ruby Range)

Dawley Canyon - see Valley View

Dead Horse - see Mud Springs

Decoy

Deep Creek - see Lime Mountain

Delano (Delno, Goose Creek?)

Delker(Delkar)

Delno - see Delano

Divide (Rock Creek)

Dolly Varden (Mizpah, Granite Sountain, Granite)

Edgemont (Centennial, White Rock)

Elk Mountain 
El ko

Empire City - see Railroad

Fairweather (Sooner) - see Mountain City.

Falcon - see Rock Creek

Ferber

Ferguson Spring (Alleghany, Allegheny)

Gitbert Canyon area

Gold Bas in (Rowland)

Gold Circle (Midas, Summit)

Gold Creek - see Island Mountain

Good Hope (Aurora, Amazon)

Goose Creek

Grand Junction - see Merrimac

Granite - see Dolly Varden

Granite Mountain - see Dolly Varden

Halleck

Harrison Pass (Ruby Range, Valley View)

Hicks

Hot Creek - see also Nye County

Humboldt Wells - see Wells

Huntington Creek (Mineral Soap mine)

Independence - see Lime Mountain

Island Mountain (Gold Creek)

Ivanhoe (Battle Mountain).

Jarbidge

Johnson - see Spruce Mountain

Kingsley - see Kinsley

Kinsley (Kingsley)

Kit Carson - see Contact

Lafayette

Latham - see Spruce Mountain

Larrabee

Lee (Ruby Range, Ruby Mountain Range)

Leroy - see Loray

Lime Mountain (Deep Creek, Independence).

Lone Mountain - see Merrimac

Loray (Leroy, Luray, Montello, Cobre, Castle Park)

Luc in (Lucine, Bueli)

Lucine - see Lucin.

Luray - see Loray

Maggie Creek - see Beaver

Mardis - see Charleston

Marseilles - see Mountain City

Medicine Springs -- see Mud Springs

Merrimac (Lone Mountain, Grand Junction)

Midas - see Gold Circle

Mineral Hill - see Eureka County

Mineral Soap mine - see Huntington Creek

Mizpah - see Dolly Varden

Montello - see Loray

Montello phosphate area

Moor 
Mountain City (Sooner, Fairweather; Murray, Marseilles, Cope, Van Duzer, Rio Tinto)

Mud Springs (Dead Horse, Medicine Springs; Butte Valley)

Murray (Murrey - see Mountain City)

New York - see Delano

Peko Hills - see Coal Mine

Pequop

Pilot Peak (Pilots Peak)

Pine Mountain - see Railroad

Polar Star - see Warm Creek

Porter - see Contact

Portis - see Contact

Proctor (Silver Zone)

Railroad (Bullion)

Rio Tinto - see Mountain City

Robinson Mountain (Copper Canyon)

Rock Creek (Falcon, formerly included Divide)

Rowland - see Gold Bas in

Ruby Range, Ruby Mountain Range - see Corral Creek, Harrison Pass, Lee, Ruby Valley, Valley View, Unknown

Ruby Valley (Smith Creek, Ruby Range)

Salmon - see Contact

Salmon River - see Contact

Silver Zone - see Proctor

Smith Creek - see Ruby Valley

Sooner (Fairweather) - see Mountain City

Spruce Mountain (Latham, Johnson, Steptoe, Black Forest)

Spruce Mountain phosphate area - see Pequop

Steptoe - see Spruce llountain

Summit - see Gold Circle

Sun Creek - see Jarbidge

Susie Creek - see Eureka County

Swales Mountain

Tecoma

Tennessee Gulch - see Alder

Tennessee Mountain - see Alder

Tuscarora

Union

Valley View (Ruby Range, Dawley Canyon, formerly included Harrison Pass)

Van Duzer (Van Duzen, Van Duyser) - see Mountain City

Warm Creek (Polar Star, Clover Valley)

Wells (Humboldt Wells)

Wendover

White Horse

White Rock - see Edgemont

Wyoming (Bruneau) - see Charleston 


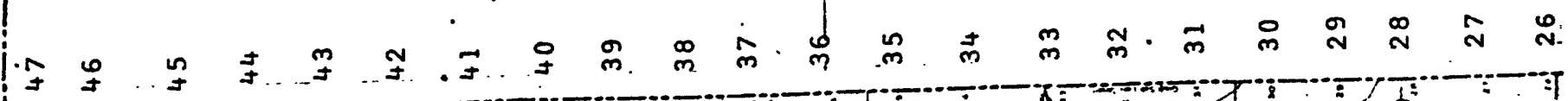

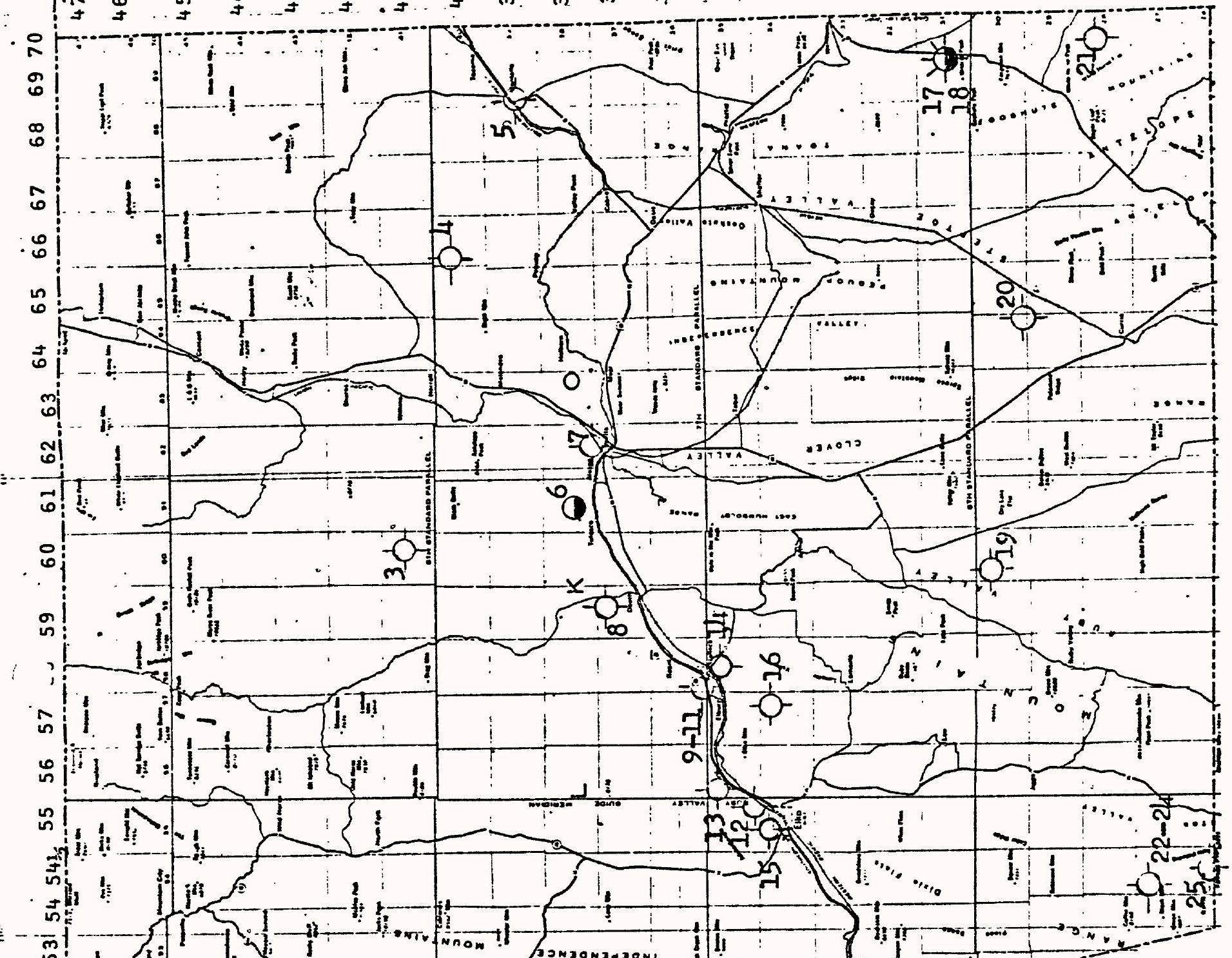

(n)

-

(1)
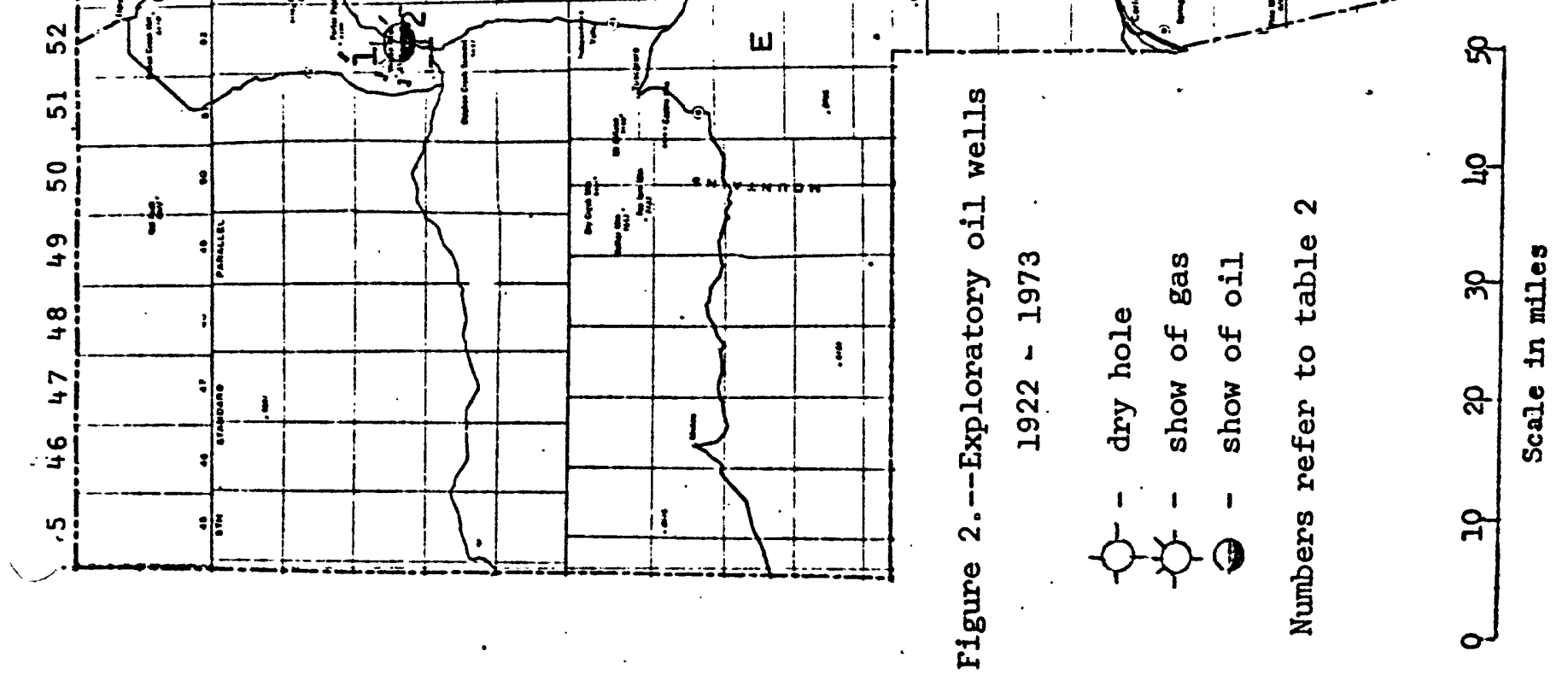


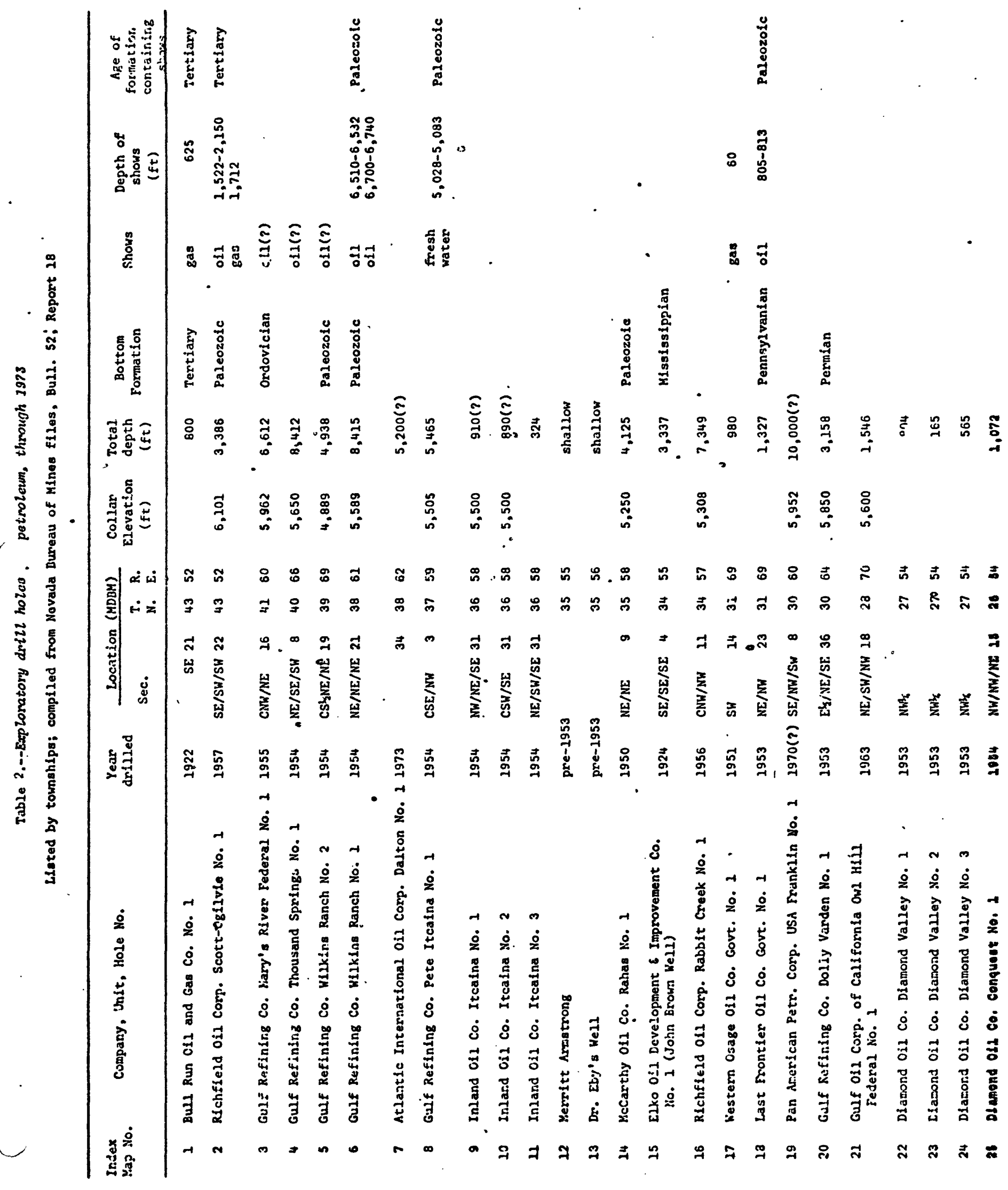


Geothermal energy is not a mineral, but its source is mineral and its use is dependent upon water. Geothermal resources have not been fully evaluated, but one Known Geothermal Resource Area (KGRA) has been designated in Elko County (see Elko district), and 10 areas have been classified as prospectively valuable (fig. 3). Sulfur Hot Springs (sec. Il, T. 31 N., R. 59 E.) has an estimated subsurface temperature of as much as $191^{\circ} \mathrm{C}$ and may be a source of geothermal power. None of the areas had been drilled as of January 1974 (Garside, 1974), but subsurface temperatures, estimated by four different methods from the chemical composition of the water (table 3 ) were reported (Hose and Taylor, 1974).

Distribution of the 32 commodities by district is shown in table 4 .

\section{Production}

of the 66 named mining districts in Elko County, 56 districts (table 5) have yielded nearly all of the recorded production. No production has been reported from the other 10 districts explored, but a small production has come from isolated deposits outside the named districts and is included with "Undistributed." Also included in "Undistributed" is unidentified production from the Ruby Mountains (see Ruby Mountain Range district).

From the time of the first discovery of coal in the Carlin district in 1859 through 1969 (table 6), the total value-when-sold of the 19 commodities produced was more than $\$ 90$ million. The largest annual production was in 1937, most of it from the Rio Tinto copper mine in the Mountain City district. This one mine accounts for 28 percent of the total metal production of the county. Largest production of a nonmetallic mineral, excluding sand, gravel, and water, has been of barite, mostly from the Rossi mine in the Bootstrap district. 


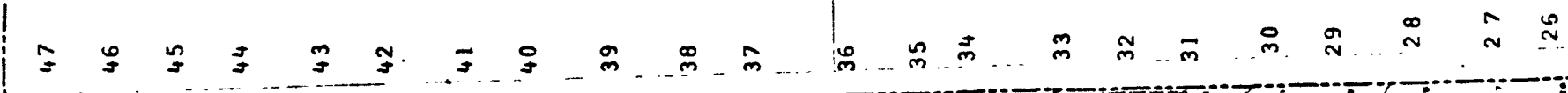

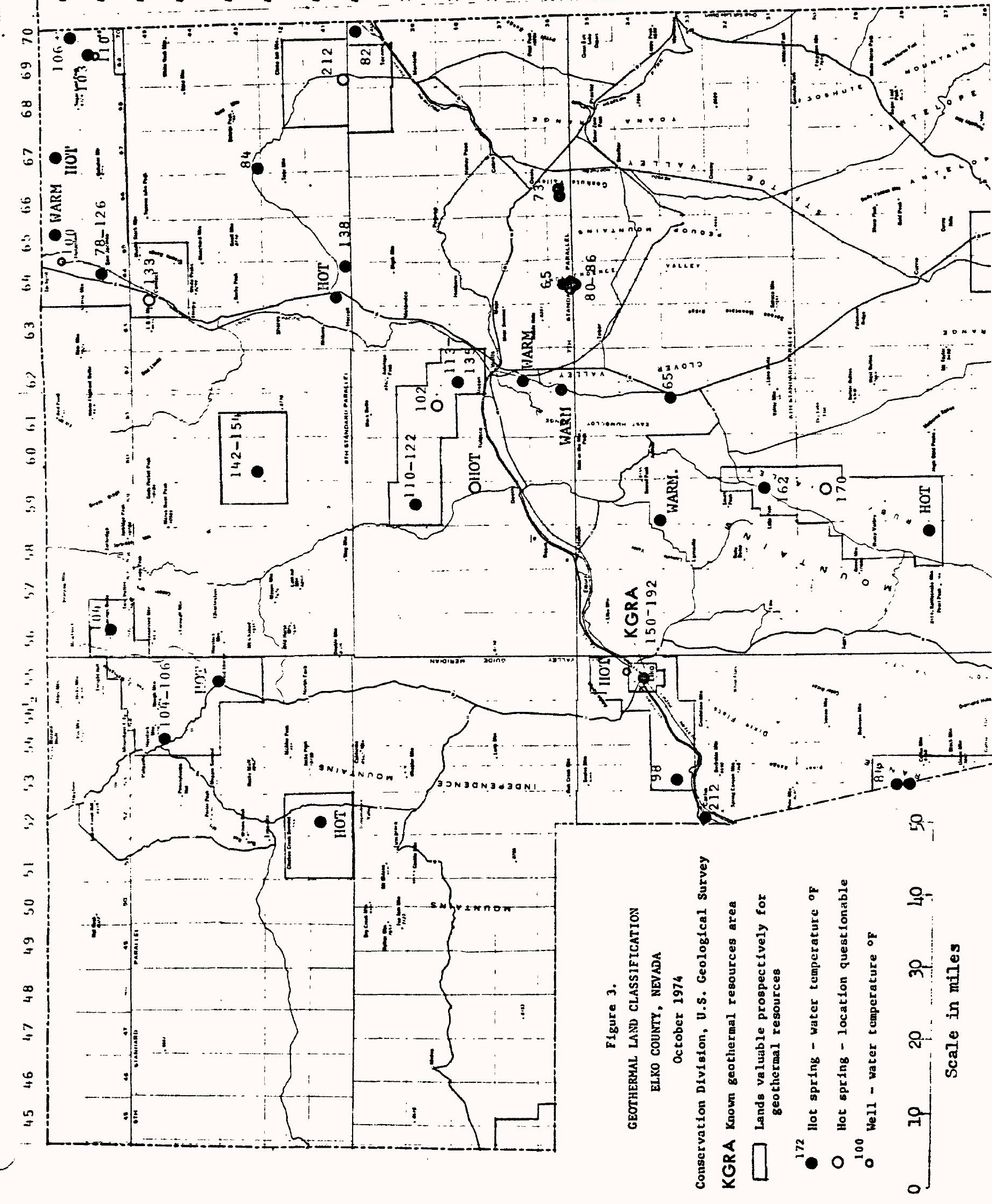




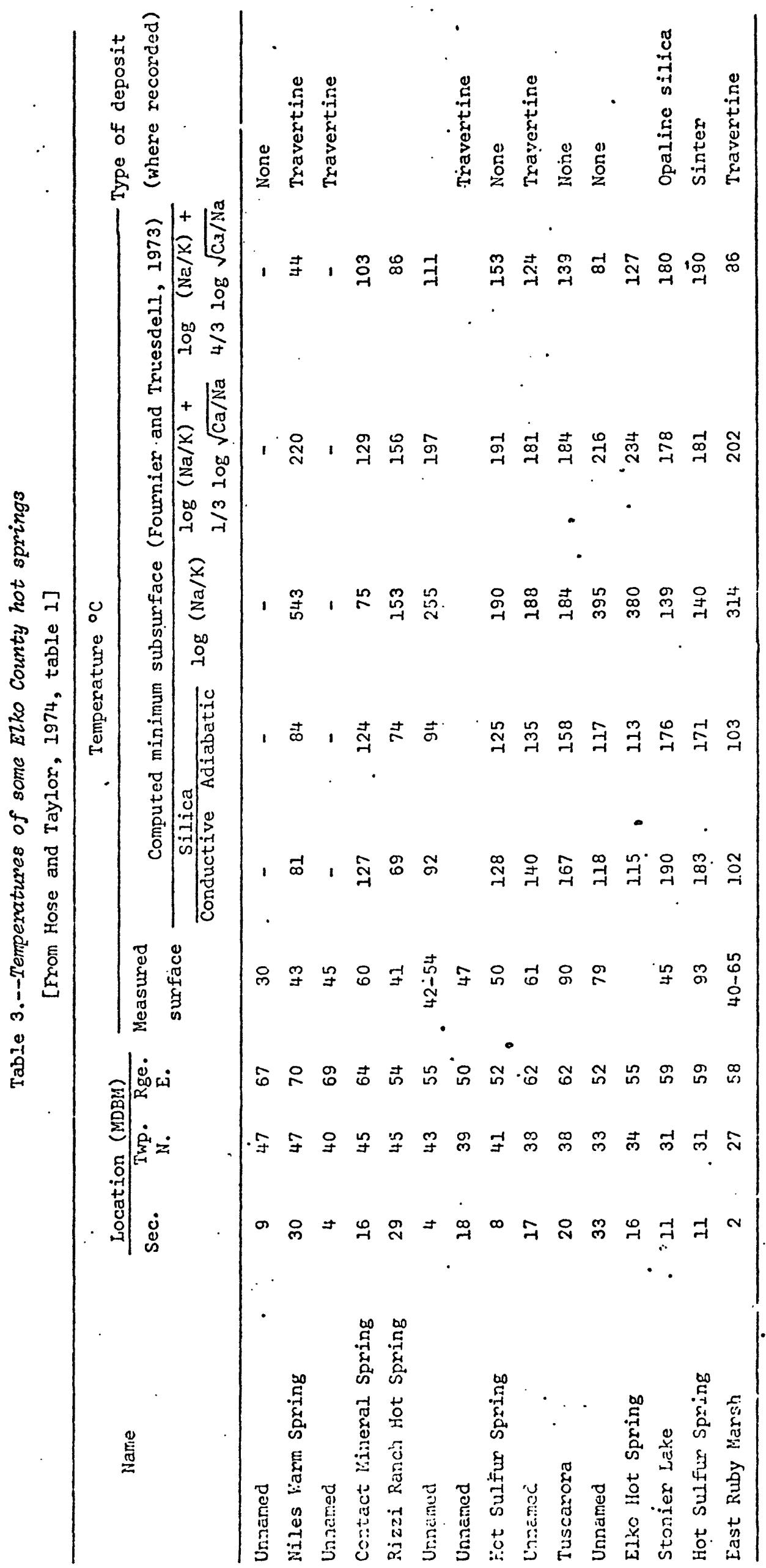


Table 4.--Diatribution of mineral doposito by diotriet, Elks County

[0, main commudity; 0 , by-pnuduct; $x$, oceurrence (no provjuct ion)]

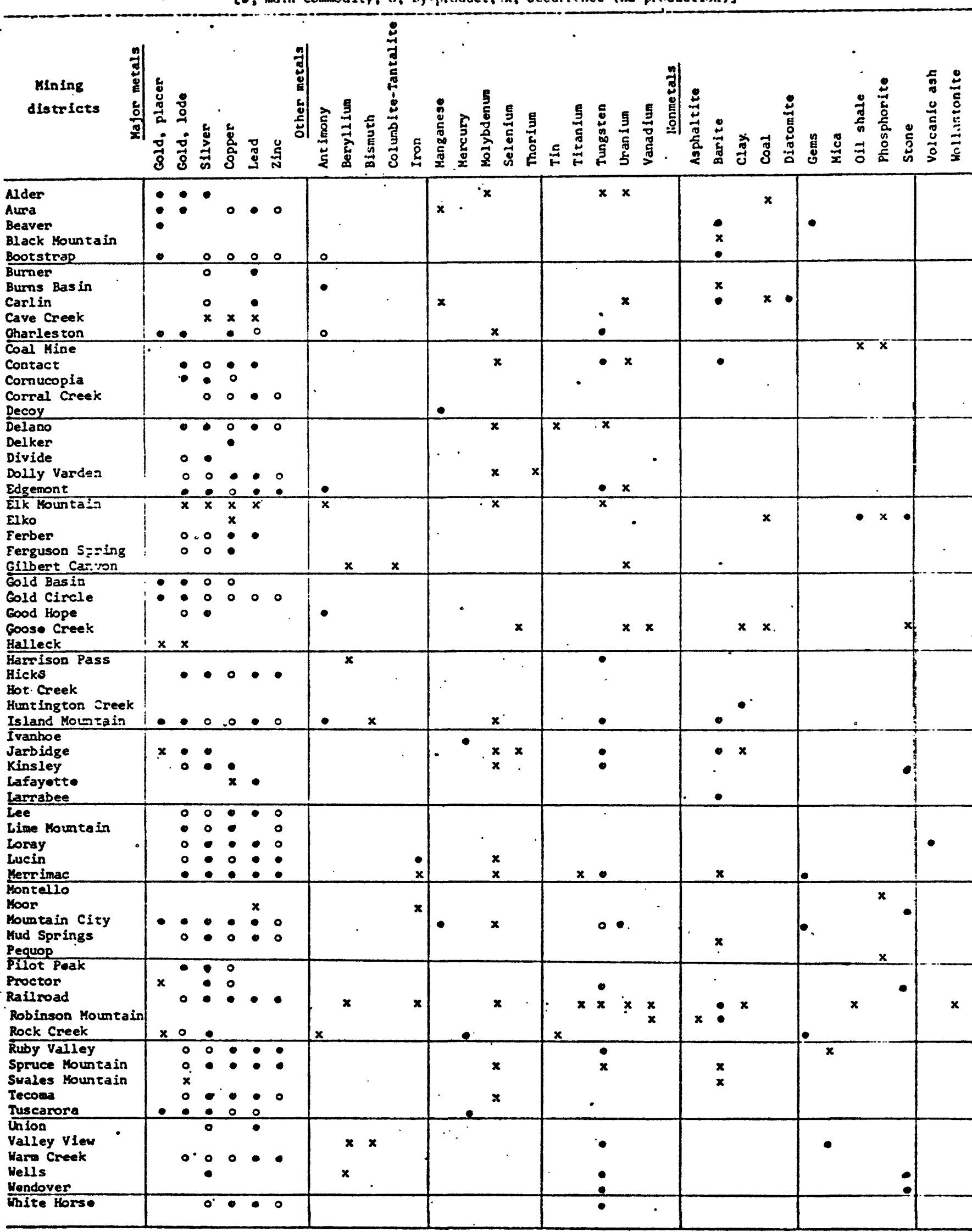


Table 5.--production of mining sistricts in Etkn County through 19to

[0, none; blank, f.1gures not avallable]

\begin{tabular}{|c|c|c|c|c|c|c|c|c|c|}
\hline District & $\begin{array}{l}\text { Ore, etc., } \\
\text { sold or } \\
\text { trested } \\
\text { (sh, tons) }\end{array}$ & $\begin{array}{l}\text { Cold } \\
\text { (oz) }\end{array}$ & $\begin{array}{l}\text { Silver } \\
\text { (oz) }\end{array}$ & $\begin{array}{l}\text { Copper } \\
\text { (1b) }\end{array}$ & $\begin{array}{l}\text { Lead } \\
\text { (13) }\end{array}$ & $\begin{array}{l}\text { zinc } \\
\text { (1b) }\end{array}$ & $\begin{array}{l}\text { Mercury } \\
\text { (flasks) }\end{array}$ & $\begin{array}{l}\text { Value } \\
\text { when } 1 / \\
\text { sold } \\
\$\end{array}$ & Other ${ }^{2 /}$ \\
\hline Alder & 75 & 27 & 503 & - & & & & 1,278 & Tungsten \\
\hline Aura & 174,643 & 67,266 & $4,293,060$ & 1,762 & 2,297 & 0 & 0 & $6,032,831$ & \\
\hline Beaver & & 0 & 0 & 0 & 0 & 0 & 0 & & Barite, turquoise \\
\hline Bootstrap & 38,636 & 9,657 & 140 & 0 & 0 & 600 & & 338,196 & $\begin{array}{r}\text { Placer gold, barite, } \\
\text { antimony }\end{array}$ \\
\hline Burner & $\underline{2 \prime}$ & 0 & $\underline{2 \prime}$ & 0 & $\underline{2}$ & 0 & 0 & 30,000 & \\
\hline Burns Basin & & & & & & & & & Antimony \\
\hline Carlin & 4 & 0.1 & 227 & 0 & 3,905 & 0 & 0 & 313 & Diatomite \\
\hline Charlest on & 1,322 & 358 & 446 & $1,77 ?$ & 970 & 0 & 0 & 10,518 & Antimony \\
\hline Contact & 62,825 & 1,110 & 91,134 & $5,007,345$ & 324,633 & 18,400 & 0 & $1,316,208$ & Tungsten, barite \\
\hline Cornucopta & 31,017 & 13,428 & 762,107 & 300 & 0 & 0 & 0 & $1,273,650$ & \\
\hline Corral Creek & 41 & 0 & & & & & 0 & & \\
\hline Decoy & & 0 & 0 & 0 & 0 & 0 & 0 & & Manganese \\
\hline Delano & 78,735 & 303 & $1,657,449$ & 157,827 & $20,517,904$ & 987,277 & 0 & $3,128,696$ & Tungsten \\
\hline Delker & 791 & 0 & 0 & 98,434 & 0 & 0 & 0 & 26,156 & . \\
\hline Divide & 26 & $12^{\circ}$ & 7,564 & 0 & 0 & 0 & 0 & 4,893 & \\
\hline Dolly Varden & $>3,928$ & 39 & 15,368 & 452,339 & 227,215 & 0 & 0 & $>75,042$ & \\
\hline Edgezont & 171,501 & 43,977 & 38,608 & 10,552 & 552,781 & 500 & 0 & 987,705 & Antimony, tungsten \\
\hline Elk Mtn. & 0 & 0 & 0 & 0 & 0 & 0 & 0 & 0 & \\
\hline Elko & 0 & 0 & 0 & 0 & 0 & 0 & 0 & 0 & Shale ofl, stone \\
\hline Ferbax & 1,498 & 58 & 21,288 & 180,040 & 500,000 & 0 & 0 & 62,243 & \\
\hline Ferģuson Spring & 356 & 1 & 394 & 44,973 & 0 & 0 & 0 & 7,037 & \\
\hline Gold Basin & 924 & 281 & 155 & 445 & 0 & 0 & 0 & 8,128 & \\
\hline Gold Circle & 401,659 & 126,968 & $1,634,752$ & 736 & 18,900 & 200 & 0 & $4,152,423$ & \\
\hline Good Hope & & & 90,909 & 0 & 0 & 0 & 0 & 100,000 & Antimony \\
\hline Goose Creek & 0 & 0 & 0 & 0 & 0 & 0 & 0 & 0 & Lignite, stone (Idaho) \\
\hline Harrison Pass & & 0 & 0 & 0 & 0 & 0 & 0 & & Tungsten \\
\hline Hicks & $>163$ & $>13$ & $>2,471$ & $>77$ & $>2,975$ & $>4,3.16$ & 0 & $>1,725$ & \\
\hline Huntington Creek & 0 & 0 & 0 & 0 & 0 & 0 & 0 & 0 & Clay \\
\hline Island Mtn. & 8,823 & 666 & 105,018 & 8,400 & $1,433,700$ & 68,500 & 0 & 357,603 & $\begin{array}{r}\text { Placer gold, antimony, } \\
\text { tungs:eil }\end{array}$ \\
\hline Ivanhoe & 67,900 & 8 & 21 & 0 & 0 & 0 & 2,166 & 220,119 & \\
\hline Jarbidge & 892,998 & 433,938 & $1,279,823$ & 129 & 0 & 0 & 0 & $10,112,423$ & \\
\hline KInsley & 898 & 102 & 14,062 & 66,203 & 145,204 & 0 & 0 & 11,338 & Tungsten \\
\hline Larrabee & 0 & 0 & 0 & 0 & 0 & 0 & 0 & 0 & Bartte \\
\hline Wee & 165 & 0 & 1,345 & 202 & 51,708 & 0 & 0 & 7,918 & \\
\hline L.1 me Mtn. & $>18,211$ & 8,123 & 25,795 & 635,156 & 0 & 28,319 & 0 & 340,000 & \\
\hline toray & $4, \$ 72$ & 4 & 29.496 & 26,005 & 487.595 & 1,727 & 0 & $78,=15$ & \\
\hline Luefa & 803 & 2 & 649 & 9,746 & 83,721 & 25,545 & 0 & 14,509 & \\
\hline
\end{tabular}


[0, none; blank, figures not available]

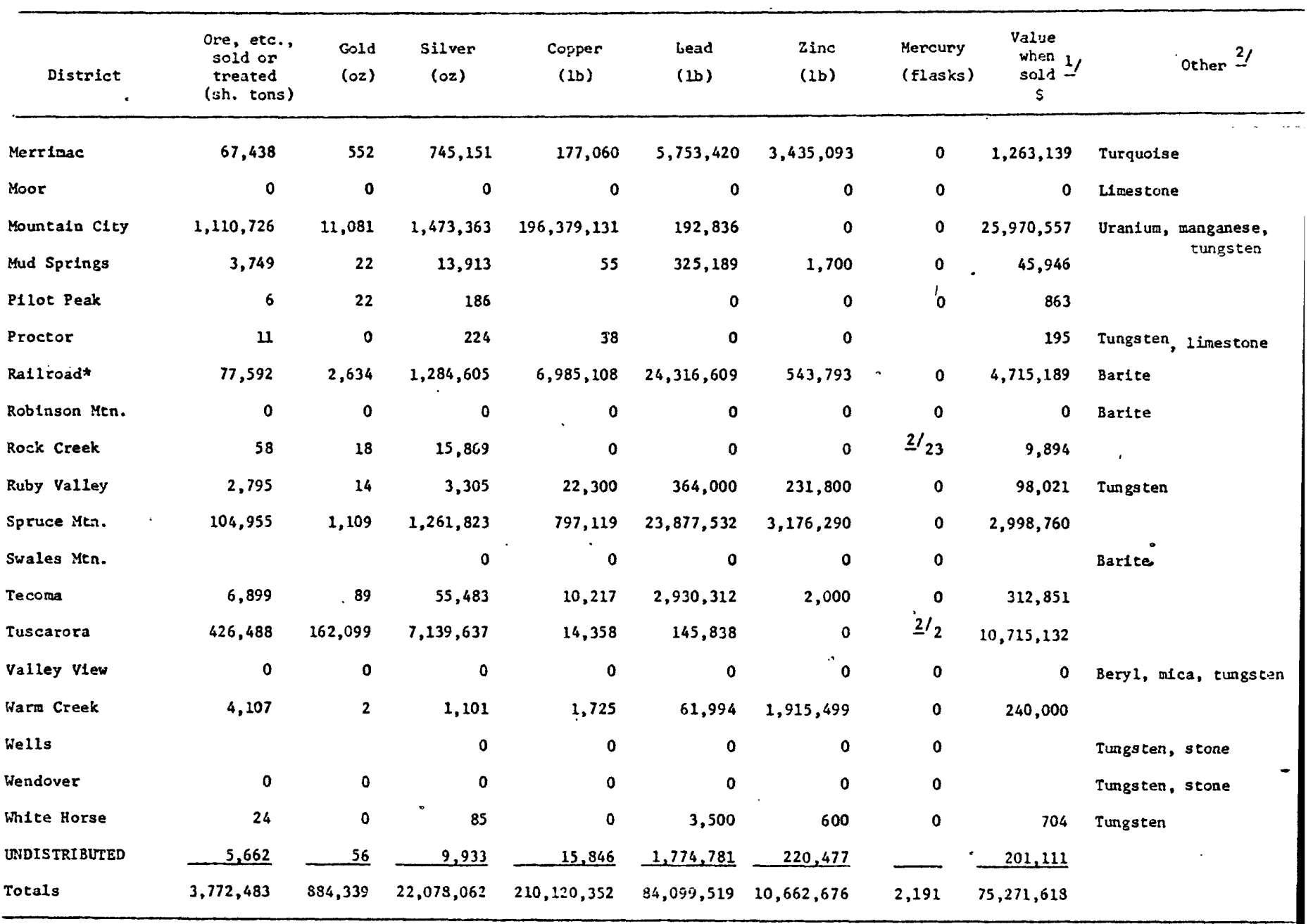

$\underline{1}$ Gold, sliver, copper, lead, zinc, mercury only

$2 /$ Production reported--not included in total tons or value

$\underline{3} /$ Includes small placer production

4/ Included in Undistributed

* Througin 1968 


\begin{tabular}{|c|c|c|c|c|}
\hline $\operatorname{Yen} x$ & $\begin{array}{l}\text { Nounber of } \\
\text { operatlng mines } \\
\text { lodely plicer2/ }\end{array}$ & 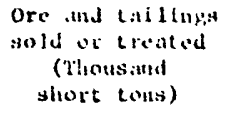 & $\begin{array}{l}\text { Tot al value } \\
\text { When sold } \\
\text { (7housind } \\
\text { dollors) }\end{array}$ & Remarks \\
\hline
\end{tabular}

1859

1860

61

62

63

64

65

66

67

68

69

1870

.71

72

73

74

75

76

77

78

79

1880

81

82

83

84

85

86

87

88

89

- 1890

91

92

93

94

95

96

97

98

99

3

88

1

6

\section{1}

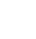

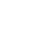

.

9

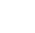

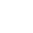

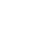

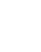

7

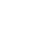

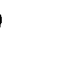

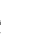

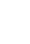

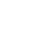

7

9

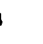

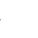

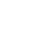

97

99

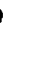

\section{Gold, sllver, copper, lead, zinc}

$+$

0

Copper discovered, Kinsley district

Placer gold discovered, Tuscarora district

Silver discovered, Aura, Mtn. City, Spruce Mtn., Rallroad, Lone Mitn.

Mtn. City silver rush; copper discovered, Contact S1lver discovered, Tuscarora district

Cornucopla sliver rush; copper discovered, Dolly varden district

Placer gold discovered, Island Mtn. distrlet

0

5

5

16

16

17

8

3

4

4

7

6

6

2

0

so

407

444

1,047

1, 281

1,094

438

156

334

526

641

312

226

222

565

538

700

484

381

183

96

41

64

106

175

199

Placer gold discovered, Charleston district

Tuscarora silver rush

sllver discovered, Good Hope district

Copper discovered, Ferber district

S1lver mines depleted, Cornucopla district

Placer gold discovered, Mtn. City (Van Duzer) district Copper discovered, Delker district

Gold discuvered, Edgemont district

Gold Creek rush, Island Mtn. district 


\begin{tabular}{|c|c|c|c|c|}
\hline Year & 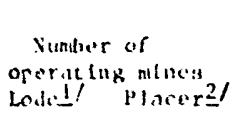 & 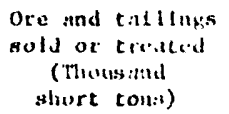 & 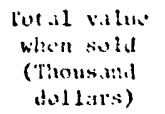 & Kenarks \\
\hline
\end{tabular}

Cold, ollver, copper, leid, zinc

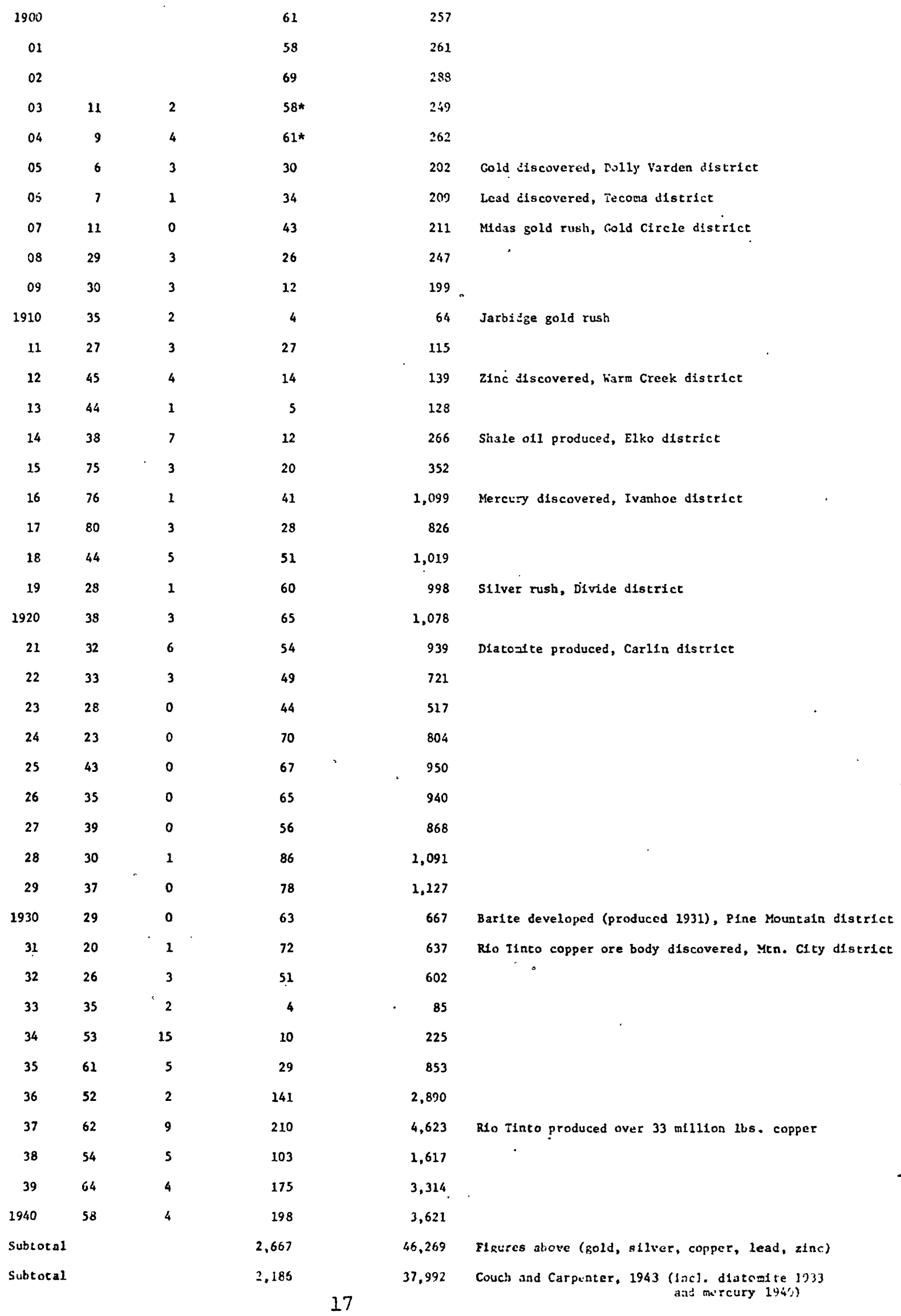




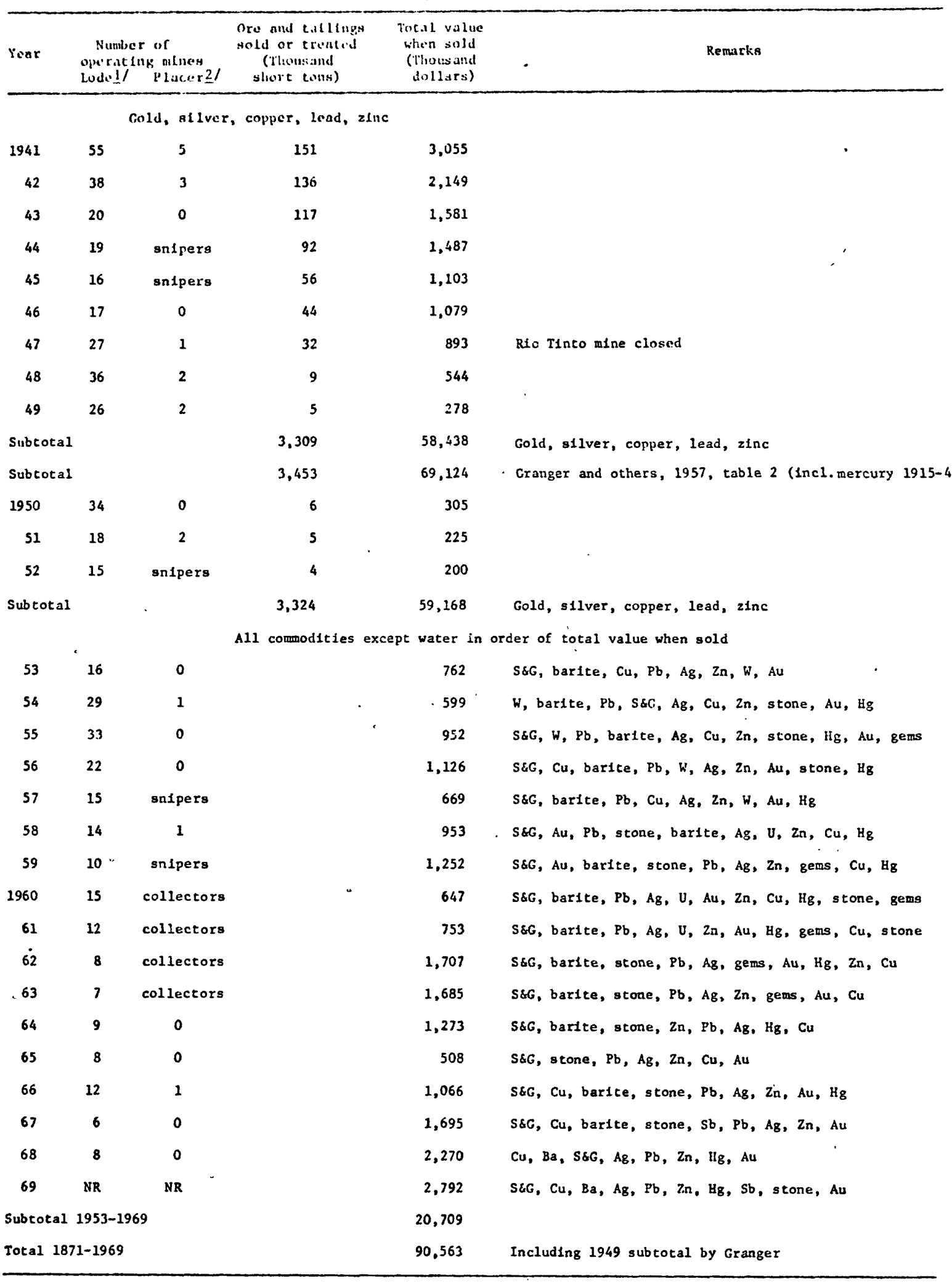

$1 /$ Excluding low-grade manganese ores 1953-1955; includes quarrles

$\underline{2}$ Excluding sand and gravel plts (S\&G) and gem collectors.

NR - No report. USBM discontinued county reports on aining and now reports farm 1acome, resident1al construction, ctc. 
DESCRIPTIONS OF MINING DISTRICTS

Alder district

Location and history

\begin{tabular}{lllll}
\hline $\begin{array}{l}\text { Sections } \\
\text { (Approx). }\end{array}$ & $\begin{array}{l}\text { T. } \\
\text { N. }\end{array}$ & $\begin{array}{l}\text { E. } \\
\text { E. }\end{array}$ & $\begin{array}{l}\text { Quadrangle name } \\
\left(7 \frac{1}{2} \text { or } 15 \text { minute) }\right.\end{array}$ & Other district names, remarks \\
\hline All & 46 & 56 & Rowland & Lost Gulch placers \\
$W^{\frac{1}{2}}$ & 46 & 57 & Rowland & Young American Creek lodes \\
$N^{\frac{1}{2}}$ & 45 & 56 & Rowland & Tennessee Gulch, Tennessee Mtn. \\
\hline
\end{tabular}

The first discoveries were gold-bearing veins. located in 1869 along Young American Creek (White, 1871). When the district was organized in 1870 it included also the Tennessee Gulch and Lost Gulch placer areas. According to Vanderburg (1936, p. 71), the "Alder or Tennessee Gulch district is * * * 10 miles south of Rowland. Considerable placer mining. was done in the early days, as indicated by the old placer tailings on Gold Run Creek, half a mile north of Baker Ranch."

The Garnet tungsten deposits discovered in 1949 (Granger and others, 1957, p. 26) on the upper southwest slopes of Tennessee Mountain are considered to be in the Alder district, but the Little Joe prospects (goldscheelite) on the southeast slope are in the Island Mountain district.

Production, principally of placer gold, during the early years is no: known. Gold was produced also from fissure veins, and a mill was built near the Parks cabin. (Bushnell, 1967, p. 34). Lode mining from 1916 through 1939 from the Clipper Alder, Mohawk, and Pittsburg Silver mines (table 7) yielded 84 tons containing 36 oz gold and 1,190 oz of silver. No production has been recorded from 1940 through 1969.

\section{Geologic setting and ore deposits}

The oldest rock formation in the district is Prospect Mountain(?) Quartzite of Lower Cambrian age. It is overlain by phyllites, limestones, and argillites of Cambrian and younger Paleozoic(?) ages, and intruded by the quartz monzonite Coffee Pot stock of Cretaceous(?) age, which underl $i=\equiv$ most of the district. The edges of the stock and the adjacent sedimentar: rocks are cut by dikes as much as $200 \mathrm{ft}$ wide of aplite and alaskite, anc locally are overlain successively by erosion remnants of older volcanics, Young America gravels, and younger volcanics. The older volcanics are Eocene(?) Bieroth Andesite 200-400 ft thick and Miocene Jarbidge Rhyolite 1,000-1,500(?) ft thick. Young America gravels are as much as $300 \mathrm{ft}$ thick and consist of pebbles and boulders of the older rocks an inch to $3 \mathrm{ft}$ in diameter. The younger volcanics are rhyolite ash, tuffs, and flows totaling about $350 \mathrm{ft}$ thick, of the Pliocene Idavada Formation.

Adjacent to the quartz monzonite the limestones are metamorphosed to marble and tactite, the argillite to hornfels. 


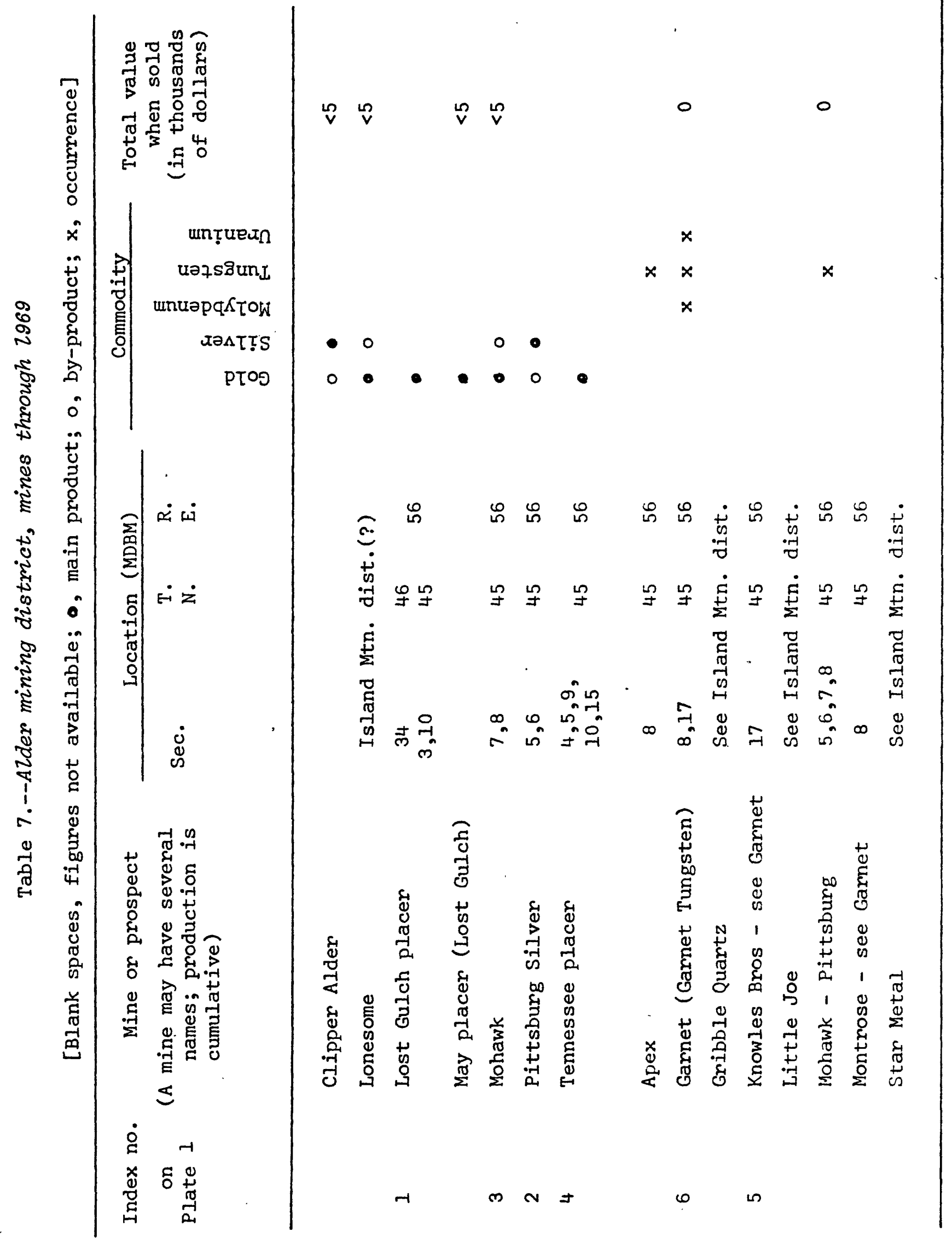


The pre-Tertiary rocks are folded, displaced in at least one locality (Trail Creek) along a bedding-plane thrust fault (western facies over eastern facies?), and are also displaced along steeply dipping normal or reverse faults that trend northeast or northwest. The early Tertiary volcanics are locally in fault contact with quartz monzonite, but the middle Tertiary gravels and later volcanics are relatively undisturbed (Bushnell, 1967).

The ore bodies are contact metamorphic deposits in the tactite, quartz veins along both sets of steep faults, and placer deposits in stream gravels.

Contact metamorphic deposits contain scheelite, powellite, molybdenite, bismuthinite, and pyrite disseminated in the tactite. The largest deposits are at the Garnet Tungsten mịne where three tactite lenses along or near aplite dikes are parallel with the bedding and dip about $60^{\circ} \mathrm{SW}$. They range in length from 100 to $500 \mathrm{ft}$, in width from 25 to $150 \mathrm{ft}$, and have been explored $400 \mathrm{ft}$ down the dip. Scheelite is disseminated throughout the tactite but is concentrated in some layers more than in others. The largest ore body has been exposed $400 \mathrm{ft}$ along the strike, $400 \mathrm{ft}$ down the dip, averages $30 \mathrm{ft}$ wide, and is estimated to contain $0.3-0.5$ percent $\mathrm{WO}_{3}$ and about 0.01 percent Mo (H. W. Jones and R. G. Reeves, written commun., 1955). No production of tungsten is recorded through 1969.

Quartz veins along faults that cut the Paleozoic rocks and the quartz monzonite contain gold. At the Gamet Tungsten mine some of the quartz veins, which are as much as 8 inches wide, contain a little scheelite. In one locality at the Garnet Tungsten mine a quartz vein about 3 inches wide along a fault gouge a foot wide cutting tactite contains as much as 3 percent $\mathrm{U}_{3} \mathrm{O}_{8}$ as pitchblende (R. E. Cohenour, written commun., 1961 ).

Placer deposit's in Tennessee Gulch, Lost Gulch, and Slate Creek yielded unknown but evidently small amounts of gold.

Aura district

Location and history

\begin{tabular}{lllll}
\hline $\begin{array}{l}\text { Sections } \\
\text { (Approx.) }\end{array}$ & $\begin{array}{l}\text { T. } \\
\text { N. }\end{array}$ & $\begin{array}{l}\text { E. } \\
\text { ( } 7 \frac{1}{2} \text { or } 15 \text { minute) }\end{array}$ & Other district names \\
\hline $34,35,36$ & 45 & 52 & Owyhee, 15' & Centennial, Bull Run \\
E $\frac{1}{2}$ & 44 & 52 & Bull Run & Centennial, Columbia, Blue Jacket \\
All & 44 & 53 & Bull Run & Centennial, Columbia, Van Duzer \\
\hline
\end{tabular}

The Aura district covers the east slope of the Bull Run Mountains, formerly. the Centennial Range, north of the site of Aura in Bull Run Basin, and south of Van Duzer Creek. Its western boundary is approximated by a north-south line through the summit of Porter Peak. 
The district has been renamed several times and includes areas formerly grouped with the Edgemont and Van Duzer districts. The first discoveries in 1868 included the Blue Jacket mine, whereupon the Bull Run district was organized in 1869. The name was later changed to White Rock (see Edgemont district) and then to Centennial. During the 1870's, placer deposits along Columbia Creek, Blue Jacket Creek, and California Gulch were worked. During the boom times of 1906, an extensive system of ditches, flumes, and pipelines was built to hydraulic the gravels in Bull Run Basin, and the town of Aura was founded on Columbia Creek $1 \frac{1}{2}$ miles below the old town of Columbia. Only a few hundred yards of gravel was washed. In 1925 another ditch was dug to bring water for hydraulicking from Blue Jacket Canyon, but this venture also was unprofitable (Vanderburg, 1936, p. 71). The placers have not been worked since, and total production is estimated to be 30 oz of gold (Johnson, 1973, p. 97). Land Office records for other placers on Trail Creek, Hutch Creek, and Wood Gulch are listed under Van Duzer district; records for the western part of the district are listed under Centennial.

Production through 1949 was reported by Granger and others (1957, p. 23). None is recorded for the years 1950-69 except a small shipment from the Aura Queen mine in 1964.

\section{Geologic setting and ore deposits}

Sedimentary rocks of the eastern assemblage--Prospect Mountain Quartzite overlain by slates, phyllites, limestones, quartzite, and cherts 18,000-20,000 ft thick of Cambrian to post-Devonian ages--are folded, faulted, and overlain by erosion remnants of metavolcanic rocks of the western assemblage in the upper plate of the Trail Creek thrust fault of pre-Jurassic age. Both plates are intruded by two dioritic stocks; the larger Columbia stock, about a mile across, is of Jurassic age. Four smaller stocks or plugs crop out in the lower plate in areas where the upper plate has been stripped away by erosion.

Three types of ore bodies, veins, replacement deposits, and placers, have been mined. Quartz veins as much as $5 \mathrm{ft}$ wide occupy faults both along and across the bedding of limestone, and contain pyrite, argentiferous galena, sphalerite, chalcopyrite, tetrahedrite, or their oxidation products, and gold. A siliceous replacement vein at the California mine (Emmons, 1910, p. 74) is also 4 or $5 \mathrm{ft}$ wide and is similarly mineralized. Gold placers along Trail Creek, because of their low gold content and the large size of the boulders, were not profitable. The gold in these placers may have been derived from the fractured rocks along the Trail creek thrust fault (Decker, 1962, p. 56).

Other types of deposits in the district have been explored. Goldbearing quartz veins cut some of the granodiorite intrusives, manganese occurs at the Maggie Summit mine, coal was reported from an unknown locality in Bull Run Basin, and shows of oil and gas were found in the two exploratory wells in Bull Run Basin (Decker, 1962, p. 57). 


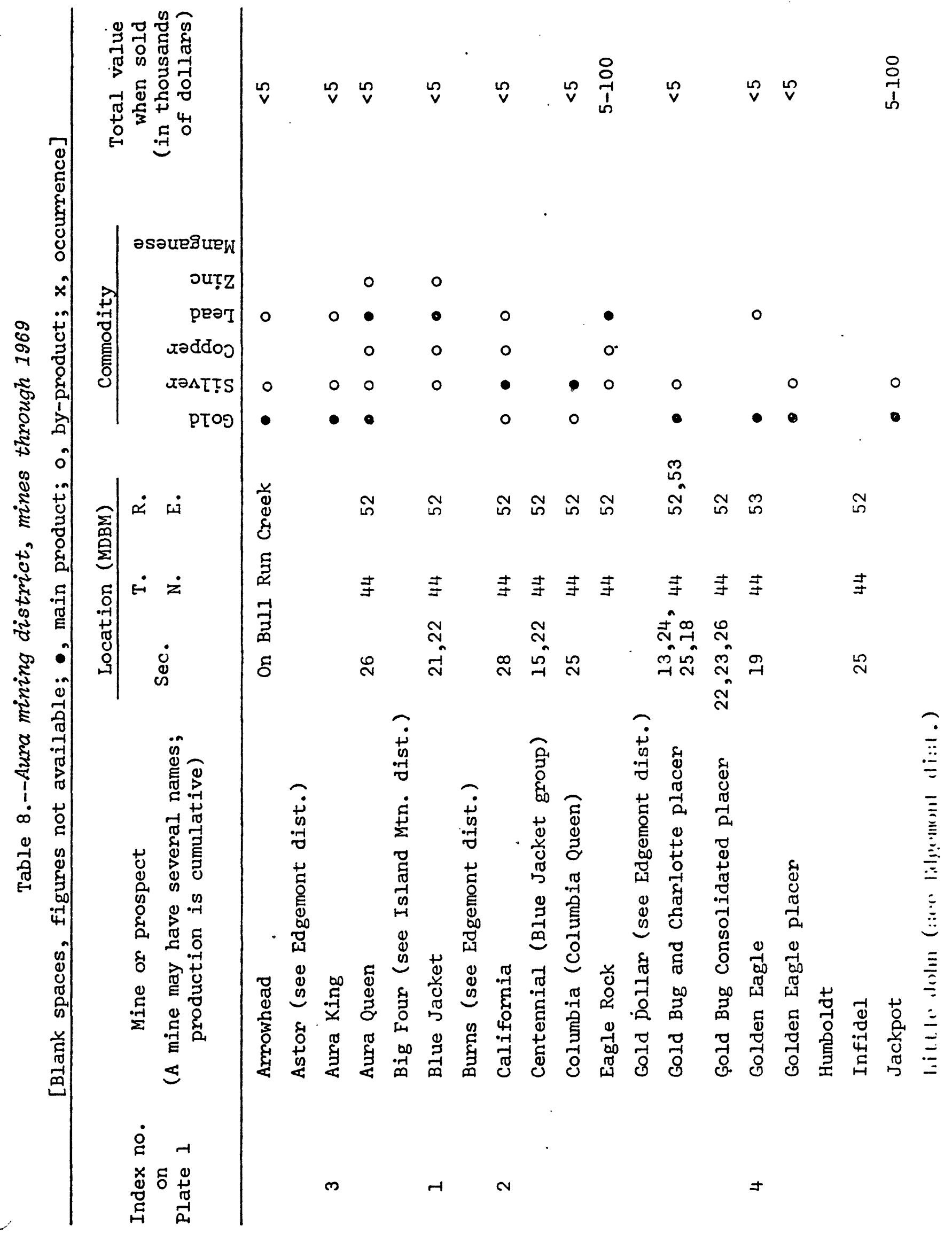




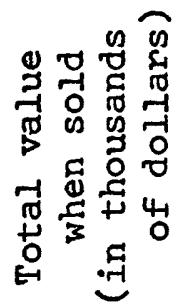

v

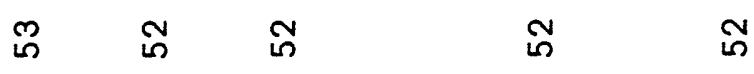

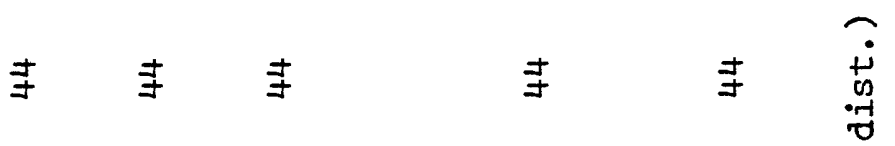

ind

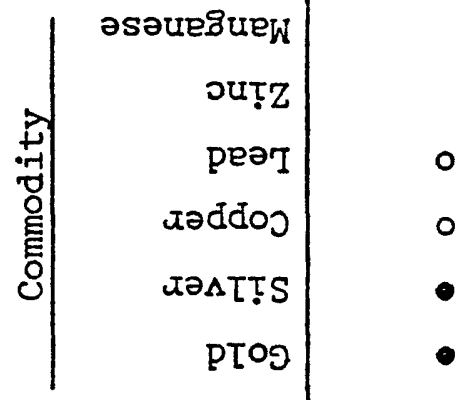

लू-

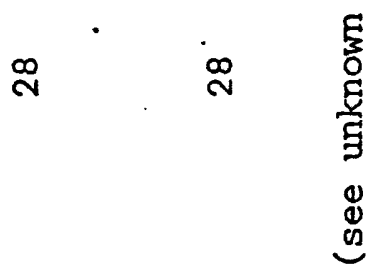

.

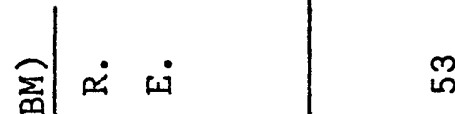

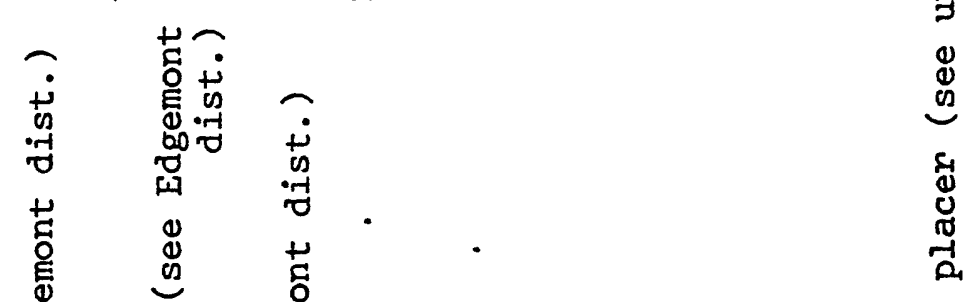

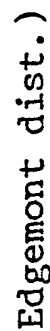

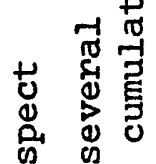

क्ष

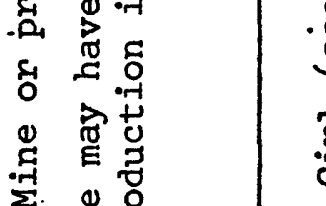

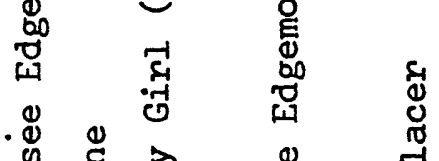

8

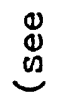

•

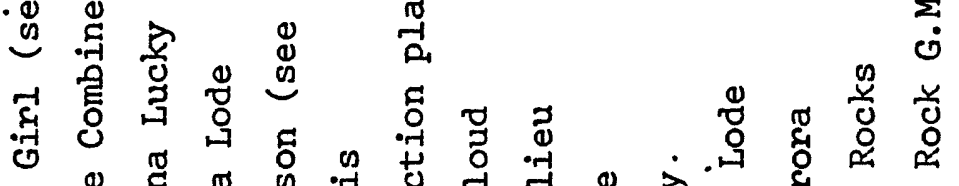

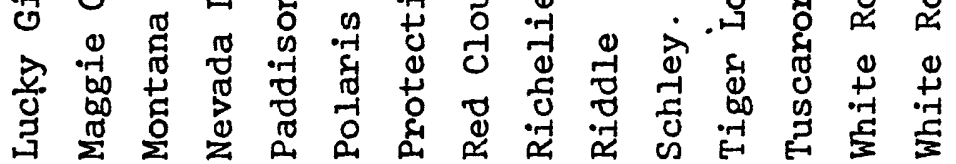

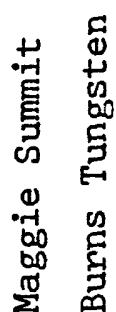

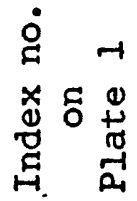


Beaver district

Location and history

\begin{tabular}{|c|c|c|c|c|}
\hline $\begin{array}{l}\text { Sections } \\
\text { (Approx.) }\end{array}$ & $\begin{array}{l}\mathrm{T} . \\
\mathrm{N}\end{array}$ & $\begin{array}{l}\text { R. } \\
\text { E. }\end{array}$ & $\begin{array}{l}\text { Quadrangle name } \\
\text { ( } 7 \frac{1}{2} \text { or } 15 \text { minute) }\end{array}$ & Other district names, remarks \\
\hline$S-1 / 6$ & 38 & 51 & McDermitt $2^{\circ}$ & \\
\hline All & 38 & 52 & McDermitt $2^{\circ}$ & Turquo ise \\
\hline All & 37 & 51 & McDermitt $2^{\circ}$ & Beaver district, 1934 \\
\hline All & 37 & 52 & McDermitt, Blue Basin & Maggie Creek placers(?) \\
\hline
\end{tabular}

The Beaver district was listed by Lotz (1934, p. 18) in T. 37 N., R. 51 E., MDBM.; As herein described, it includes Beaver and other creeks north of Dalton Peaks which drain into Maggie Creek along the east slope of the Tuscarora Mountains.

Turquoise was produced from gold placers in this area during the Tuscarora boom, but the amount is not known.

A few tons of silver-gold ore reportedly produced in 1906 by the Nevada Star Mining Company from the Maggie district in Elko County (U.S. Geol. Survey, 1906, p. 293) probably should be credited to the Nevada Star mine in the Maggie Creek district in Eureka County.

The Stampede turquoise mine, which operated before 1968, is an open pit about $70 \mathrm{ft}$ long and $40 \mathrm{ft}$ wide near the crest of a southerly trending ridge in the $\mathrm{SE}^{\frac{1}{4}} \mathrm{sec} .9, \mathrm{~T} .38 \mathrm{~N} ., \mathrm{R} 52$. E. Total production of turquoise including the early placer production is less than $\$ 500,000$.

Barite was produced from the Jones Marvel mine in 1962.

Geologic setting and ore deposits

In the locality of the Stampede mine strata of black chert and gray quartzite that strike N. $65^{\circ} \mathrm{E}$. and dip $65^{\circ} \mathrm{NW}$. are cut by numerous fractures which dip $45^{\circ} \mathrm{SE}$. Turquoise occurs as nodules and seams along bedding planes in the chert and the quartzite, and also as float in the gullies. The turquoise is extremely hard and of good color; solid-blue, matrix-marked, and spider-web varieties have been produced (Morrissey, 1968, p. 5).

Barite at the Jones Marvel mine is reported to be a bedded-type deposit (Horton, 1963, p. 7). It replaces limestone lenses in strata of the western facies (R. R. Coats, written commun., 1975). 


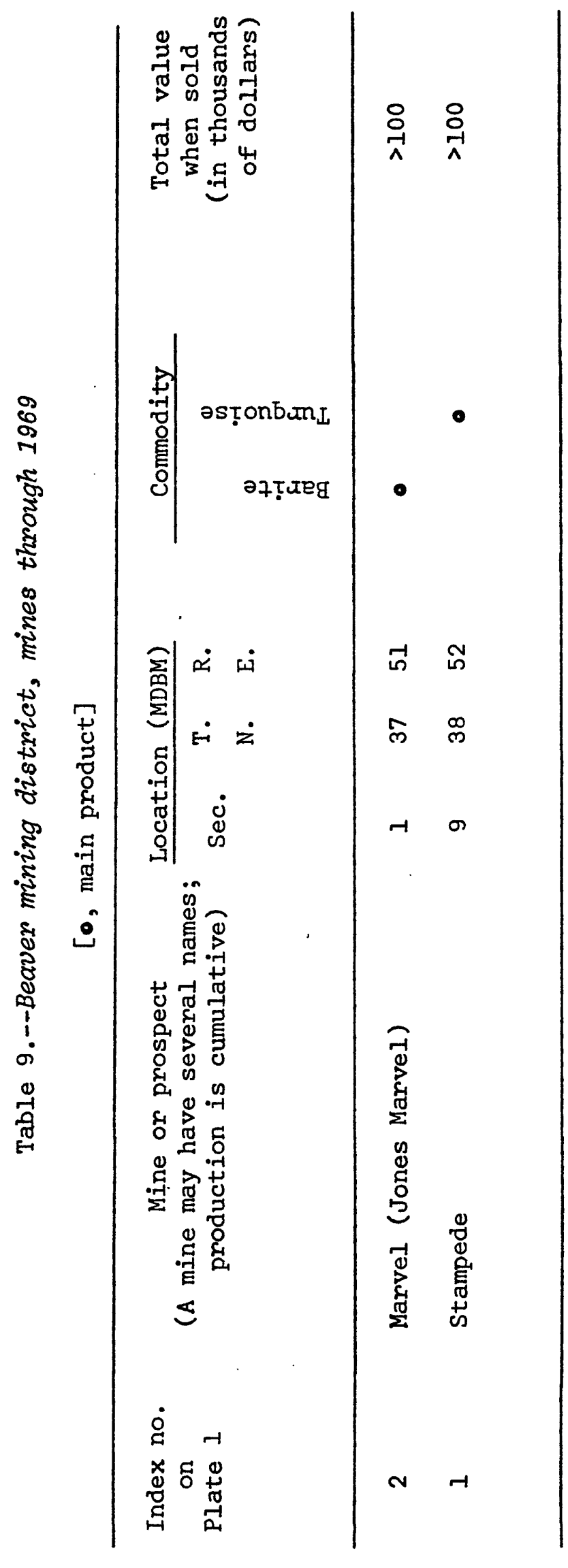


Black Mountain district

Location and history

\begin{tabular}{|c|c|c|c|c|}
\hline $\begin{array}{l}\text { Sections } \\
\text { (Approx.) }\end{array}$ & $\begin{array}{l}\text { T. } \\
\text { N. }\end{array}$ & $\begin{array}{l}\text { R. } \\
\text { E. }\end{array}$ & $\begin{array}{l}\text { Quadrangle name } \\
\text { ( } 7 \frac{1}{2} \text { or } 15 \text { minute) }\end{array}$ & Other district names; remarks \\
\hline $34,35,36$ & 40 & 64 & Wine Cup Ranch ȘW & No published data \\
\hline $\mathrm{NE}^{1 / 4}$ & 39 & 64 & Wine Cup Ranch SW & \\
\hline
\end{tabular}

Black Mountain is about 18 miles airline northeast of Wells. Two prospects, one on the east slope (sec. 2, T. 39 N., R. 64 E.) and the other on the west slope (sec. 10), are shown on the topographic map of the quadrangle. No production has been reported from the area.

Geologic setting

Black Mountain, a north-trending ridge about 4 miles long, is composed of sedimentary rocks ranging in age from Devonian to Permian. No igneous rocks have been mapped in this locality. The oldest strata are dolomites of the Simonson and Sevy Formations overlain by limestones of the Guilmette or Devils Gate Formation exposed along the crest of the ridge. They are in fault contact with younger limestone (Mississippian) strata exposed along the west side of the ridge and with still younger siltstones and cherts of the Carlin Canyon sequence (Permian) exposed in the east half of the district. In a few nearby places west of the ridge these Permian rocks comprise remnants of the upper plate of a thrust fault.

The prospect adits in sec. 2 explored a breccia zone about $10 \mathrm{ft}$ wide that dips steeply west in limestone of the Nevada Formation. The breccia is cemented and partly replaced by strontium-bearing barite and calcite.

Bootstrap district

Location and history

\begin{tabular}{lllll}
\hline $\begin{array}{l}\text { Sections } \\
\text { (Approx.) }\end{array}$ & T. & R. & $\begin{array}{l}\text { Quadrangle name } \\
\left(7 \frac{1}{2} \text { or } 15 \text { minute) }\right.\end{array}$ & Other district names \\
\hline All & 37 & 49 & Santa Renia Fields & Boulder Creek \\
$N-1 / 3$ & 36 & 49 & Santa Renia Fields & Boulder Creek \\
\hline
\end{tabular}

The district includes much of the drainage areas of Boulder and Antelope Creeks on the west slopes of the Tuscarora Mountains. Another Boulder Creek on the east side of the range south of Tuscarora is not included.

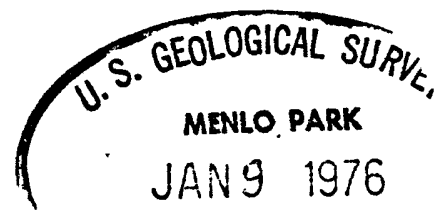


The area was. called the Boulder Creek district from 1953 to about 1960 , but was later known as the Bootstrap district after the Bootstrap mine. became the largest gold producer in the county in 1958. From 1953 through 1969 the district yielded a little more than half a million tons of barite having an average value of about $\$ 6.65$ per ton. The Rossi mine is one of the two largest barite mines in the United States, the other being the Greystone mine in Lander County.

A load of antimony ore from the Bootstrap mine was hauled to Dunphy in 1914 but was never shipped (Lawrence, 1963, p. 58).

During 1972 the Newmont Mining Co. was preparing to reopen the Bootstrap mine in Elko County and the nearby Blue Star mine in Eureka County, estimated to contain over a million tons of low-grade gold ore which could be mined profitably at the higher gold price then in effect.

In the Bootstrap mine area thick-bedded limestones of Devonian age, which closely resemble the Popovich Formation at the Carlin mine, are exposed in a window through the overlying cherts, shales, and limestones of the Vinini Formation of Ordovician age, and separated from them by the Roberts Mountains thrust fault. The Vinini strata are cut by many steep north-trending faults and intruded by quartz latite to dacite dikes as much as $15 \mathrm{ft}$ wide along some of the faults. Gold occurs, mostly as microscopic particles, along fractures in the dikes and in the cherts and shales near the dikes. Where several dikes are spaced closely, ore bodies are minable by open-pit methods. A few samples, not necessarily representative of the average grade, contained 0.10-0.3 oz gold per ton (A. S. Radtke, oral commun., 1973). Gravels from the Bootstrap placer averaged $0.024 \mathrm{oz}$ gold per ton.

Burner district

Location and history

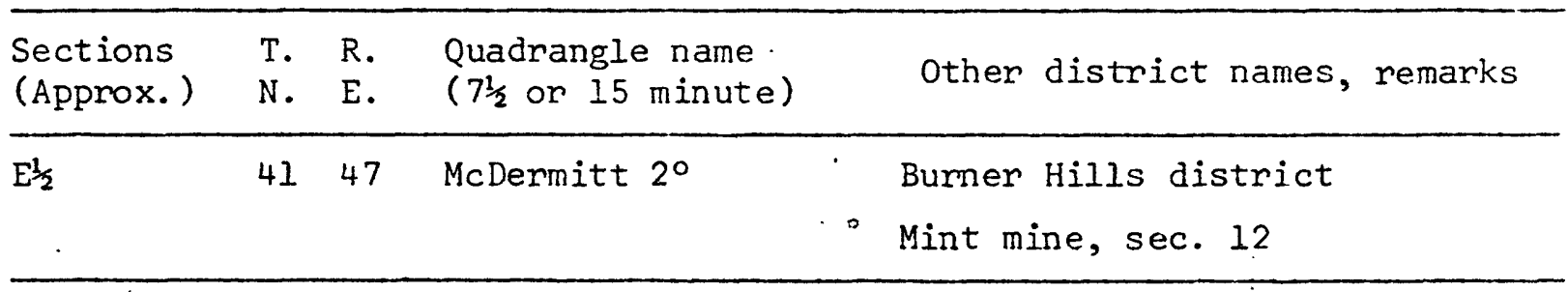

The Burner district covers the Burner Hills, an isolated group of hilis about 2 by 3 miles across, which rise to altitudes of $6,200 \mathrm{ft}$, but only about $700 \mathrm{ft}$ above the undulating plain of the Owyhee Desert. According to Emmons (1910, p. 67), "A number of claims are located in these hills, but the Mint mine is the only one on which any considerable amount of work has been done. This mine was operated in the early eighties and shipped about $\$ 30,000$ worth of lead-silver ore to smelters. Active operations were suspended in 1893, and since that time but little work has been done." No further production has been recorded from the district through 1969, but exploration at the Silver Ace (Burner Hill or Mint) mine was reported during 1961-64. 


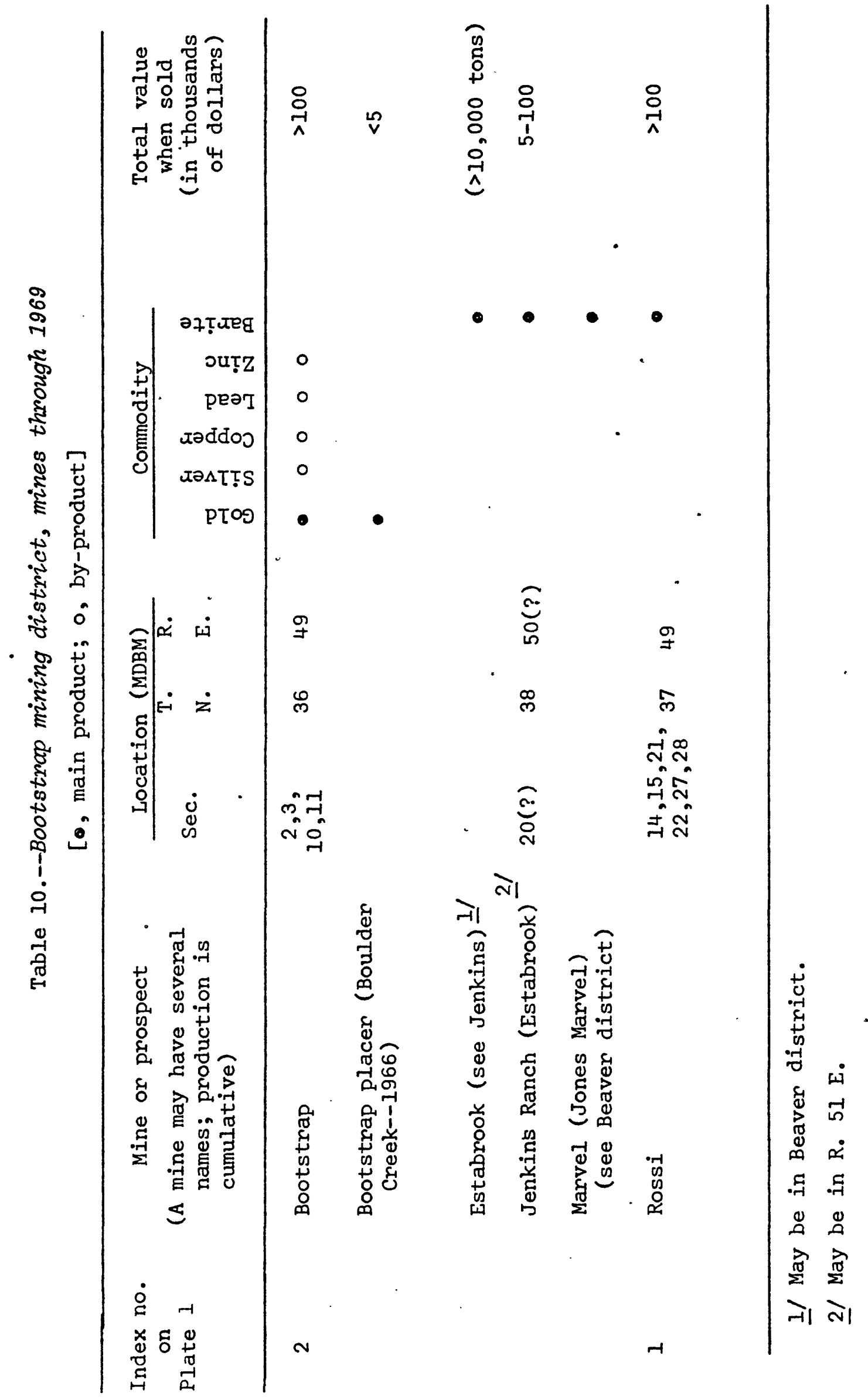


The Mint mine is developed by a crosscut adit driven southwestward $175 \mathrm{ft}$ to the lode, by a drift S. $25^{\circ} \mathrm{W}$. for $300 \mathrm{ft}$ along the lode, by a winze of unreported depth, and by small stopes above and below(?) the level.

\section{Geologic setting and ore deposits}

The oldest rocks exposed in the district are interbedded chert, shale, argillite, and quartzite of the Valmy Formation of Ordovician age which crops out on the east slope of the Bumer Hills (SW/4 sec. 13). Younger interbedded chert, shale, argillite, and limestone of the Havallah sequence of Permian-Mississippian age also crop out on the slopes farther north ( $S W^{\frac{1}{4}} \mathrm{sec} .12$ ) and dip away from the central axis of the hills. These formations are overlain by flows of unweathered andesite and by rhyolite tuffs and pumice of Miocene-Oligocene age, which in turn are overlain by rhyolite tuffs of Miocene age. Basalt gravels of the Banbury Formation, also of Miocene age, cover the plains to the north and west.

The sedimentary rocks and the andesite are cut by faults that trend northeastward and dip steeply or are vertical. One of the vertical faults in the andesite contains the Mint lode; other faults in the sedimentary rocks south of the Mint mine contain small quartz veins that cut across the bedding and stringers parallel to the bedding.

At the Mint mine the ore bodies are veinlets parallel to the walls and irregular masses in hydrothermally altered andesite in a fault zone up to $4 \mathrm{ft}$ wide. They were mined from small stopes for $300 \mathrm{ft}$ along the adit level and an unreported distance above and below it. The ore consists of argentiferous galena, sphalerite, pyrite, arsenopyrite, and chalcopyrite in a gangue of quartz and calcite. Near the surface lead carbonate and iron oxide are present (Emmons, 1910, p. 67). According to Emmons "the high-grade ore is said to be irregular and bunchy in the vein, but a zone up to $4 \mathrm{ft}$ wide is regarded by the owners as available for concentrating, as a considerable proportion of the silver values is in the galena."

Burns Basin district

Location and.history

\begin{tabular}{lllll}
\hline $\begin{array}{l}\text { Sections } \\
\text { (Approx. })\end{array}$ & $\begin{array}{l}\text { T. } \\
\text { N. }\end{array}$ & $\begin{array}{l}\text { R. } \\
\text { E. }\end{array}$ & $\begin{array}{l}\text { Quadrangle name } \\
\left(7 \frac{1}{2} \text { or } 15 \text { minute }\right)\end{array}$ & Other district names \\
\hline All & 40 & 53 & $\begin{array}{c}\text { Tuscarora, Mahala } \\
\text { Creek West }\end{array}$ & Byrne Basin \\
\hline
\end{tabular}

The Burns Basin district covers the area of Burns Basin on the west slope of the Independence Mountains about 12 miles east of Tuscarora. The only mine in the district for which production has been recorded is the Burns Basin antimony mine, also known as the Lonesome Kid, Williams, Parker, Chaffie, Griffith, or Andrae mine, but antimony and barite prospects have been found along the range both north and south of the district from Taylor Canyon to Jacks Peak: 


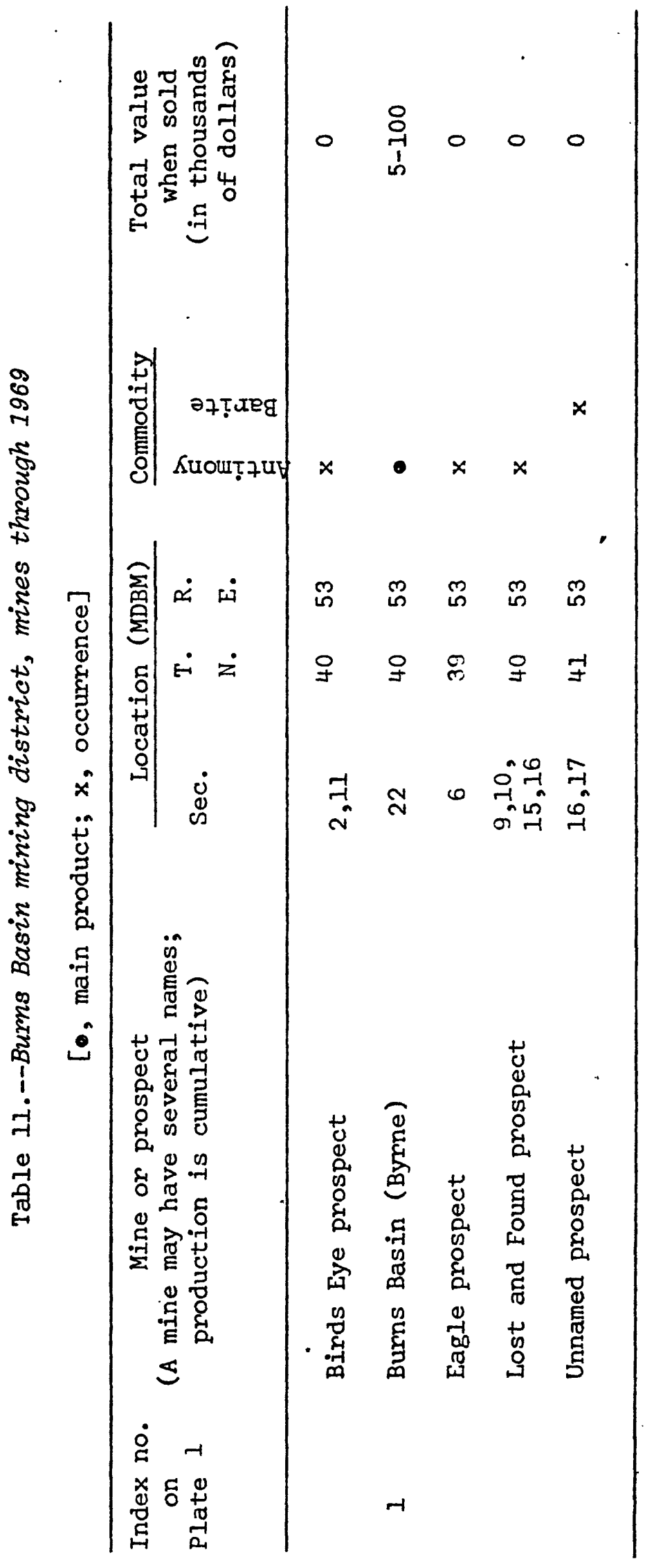


The Burns Basin mine is near the head of Burns Creek. It is developed by a 29-ft vertical shaft, $80 \mathrm{ft}$ of underground workings, and an open pit. Total recorded production is 20 tons of antimony metal in 1918 and $12 \frac{1}{2}$ tons in 1945.

Geologic setting and ore deposits

(Lawrence, 1963, p. 47-48)

At the Burns Basin mine thin-bedded limestone of Paleozoic age strikes $\mathrm{N} .20^{\circ} \mathrm{E}$. and dips $10^{\circ} \mathrm{E}$. It is cut by a fracture zone $12-18$ inches wide that strikes $N .10^{\circ} \mathrm{W}$. and dips $75^{\circ} \mathrm{W}$. The zone is silicified and some fractures contain calcite and quartz. In the footwall of the fracture zone the limestone is brecciated. Stibnite and its oxidation products occur as single crystals, pods, and veinlets up to three-fourths of an inch wide in the brecciated limestone and along the bedding planes, mostly within $10 \mathrm{ft}$ of the fracture zone. Barite crystals also occur along the fractures with the stibnite; in other deposits they are perched on the stibnite. A sample of stockpiled ore contained 17 percent stibnite and $0.5 \mathrm{oz}$ silver per ton.

Carlin district

Location and history

\begin{tabular}{|c|c|c|c|c|}
\hline $\begin{array}{l}\text { Sections } \\
\text { (Approx.) }\end{array}$ & $\begin{array}{l}\text { T. } \\
\text { N. }\end{array}$ & $\begin{array}{l}\text { R. } \\
\text { E. }\end{array}$ & $\begin{array}{l}\text { Quadrangle name } \\
\text { ( } 7 \frac{1}{2} \text { or } 15 \text { minute) }\end{array}$ & Remarks \\
\hline$s-1 / 3$ & 34 & 52 & Huntsman Ranch & "Prospect" on quadrangle map \\
\hline$E-5 / 6$ & 33 & 52 & - Huntsman Ranch, Carlin & Diatomite, manganese \\
\hline$W \frac{1}{2}$ & 33 & 53 & Huntsman Ranch, Carlin & Diatomite, coal \\
\hline$E-5 / 6$ & 32 & 52 & Carlin & Uranium \\
\hline$W \frac{1}{2}$ & 32 & 53 & Carlin & Uranium \\
\hline
\end{tabular}

The Carlin district covers the mountainous areas for about 7 miles north and south of Carlin, and from Carlin (Moleen) Canyon westward to the Eureka County line. The district does not include the Carlin gold mine which is in the Lynn district in Eureka County about 18 miles northwest of Carlin.

Coal was discovered in $1859,2 \frac{1}{2}$ miles east of Carlin and south of the Humboldt River. The deposit was explored by the Humboldt Coal Company with three shafts 60-80 ft deep and four parallel adits driven toward the shafts. The coal was reported to contain 46 percent carbon, and to burn freely leaving a white ash. Work was suspended in 1874 due to the large quantities of water encountered (Whitehill, 1875, p. 29). The company was still active during the years 1895-37, but no production was reported. There are no reports of subsequent work on the deposit. 
Lead-silver ore from the Wagner mine is credited to the Carlin district for 1908, but the location of the mine. is not known. Gold production of $15 \mathrm{oz}$ from the Big Six mine in 1908, and about $10 \mathrm{oz}$ of placer gold in 1934, was formerly credited to the Carlin district, but the Big Six gold mine and associated placers are in the Lynn district in Eureka County.

A diatomite deposit $1 \frac{1}{2}$ miles north of Vivian siding was mined by underground methods from 1921 through. 1952. Production figures were not published, but in 1922 the capacity of the grinding and air-classifying plant at Vivian was 12 tons per day ( Lincoln, 1923, p. 39), and in 1926 the deposit was being mined at the rate of 2,000 tons per year (EardleyWilmot, 1928, p. 105). Most of the product was sold for use as insulation. Average value at the mine of 928 tons reported for 1933 was $\$ 8.44$ per ton (Couch and Carpenter, 1943, p. 41).

Uranium deposits on the Deerhead (Deerhorn) and Black Kettle claims were prospected in 1956, but no production resulted.

Barite from the Graves mine was shipped from Carlin in 1956; the location of the deposit is not known.

Mangariese deposits at the Berning prospect were explored, but there has been no production.

\section{Geologic setting and ore deposits}

Oil shale occurs in the Elko Formation (Smith and Ketner, 1974) of Eocene-Oligocene age which in its type section near the 1 ine between secs. 10 and 15, T. 31 N., R. 53 E., is $2,075 \mathrm{ft}$ thick. About half of the strata near the middle are composed of carbonaceous laminated papery shales that weather nearly white, but their area and thicknes's do not indicate a commercial tonnage under 1974 economic conditions.

In the area of the Tri-0-Lite mine a bed of diatomite $15 \mathrm{ft}$ thick crops out at intervals for several miles. It is underlain and overlain by a friable limy rock interlayered with thin beds of clay, all of late Miocene(?) age. The strata are tilted $35^{\circ} \mathrm{SE}$. and are cut by many small faults.

The diatomite bed tapers to a thin hard seam at its southern edge, but in most places the edges of the original basin have been eroded away. The central $10 \mathrm{ft}$ of the deposit, which was the only part mined, contains a thin stratum of limy rock in the middle; the best grade of diatomite occurs below this stratum. The diatoms are well-preserved, fairly uniformly sized, cylindrical Melosira granulata. The diatomite contains about 15-20 percent moisture (Eardley-Wilmot, 1928, p. 105).

In the locality of the Deerhead uranium claims; thin-bedded black shale conformably overlain by water-laid(?) tuff strikes $\mathrm{N}$. $40^{\circ} \mathrm{W}$. and dias $23^{\circ} \mathrm{NE}$. These strata are cut by a fault that strikes N. $50^{\circ} \mathrm{W}$. and dips $75^{\circ} \mathrm{NE}$. Shale and tuff along the fault are brecciated and silicified for $a$ width of about $20 \mathrm{ft}$. Carnotite occurs in small flakes in the breccia and in slope'wash near the breccia. Samples containing as much as 0.03 percent $\mathrm{U}_{3} \mathrm{O}_{8}$ were reported ( $\mathrm{H}$. W. Jones, written commun., 1957).

A 50-ft shaft on the nearby Black Kettle claim yielded samples containing up to 0.04 percent $\mathrm{U}_{3} \mathrm{O}_{8}$ (W. E. Peterson, written commun., 1960 ). 


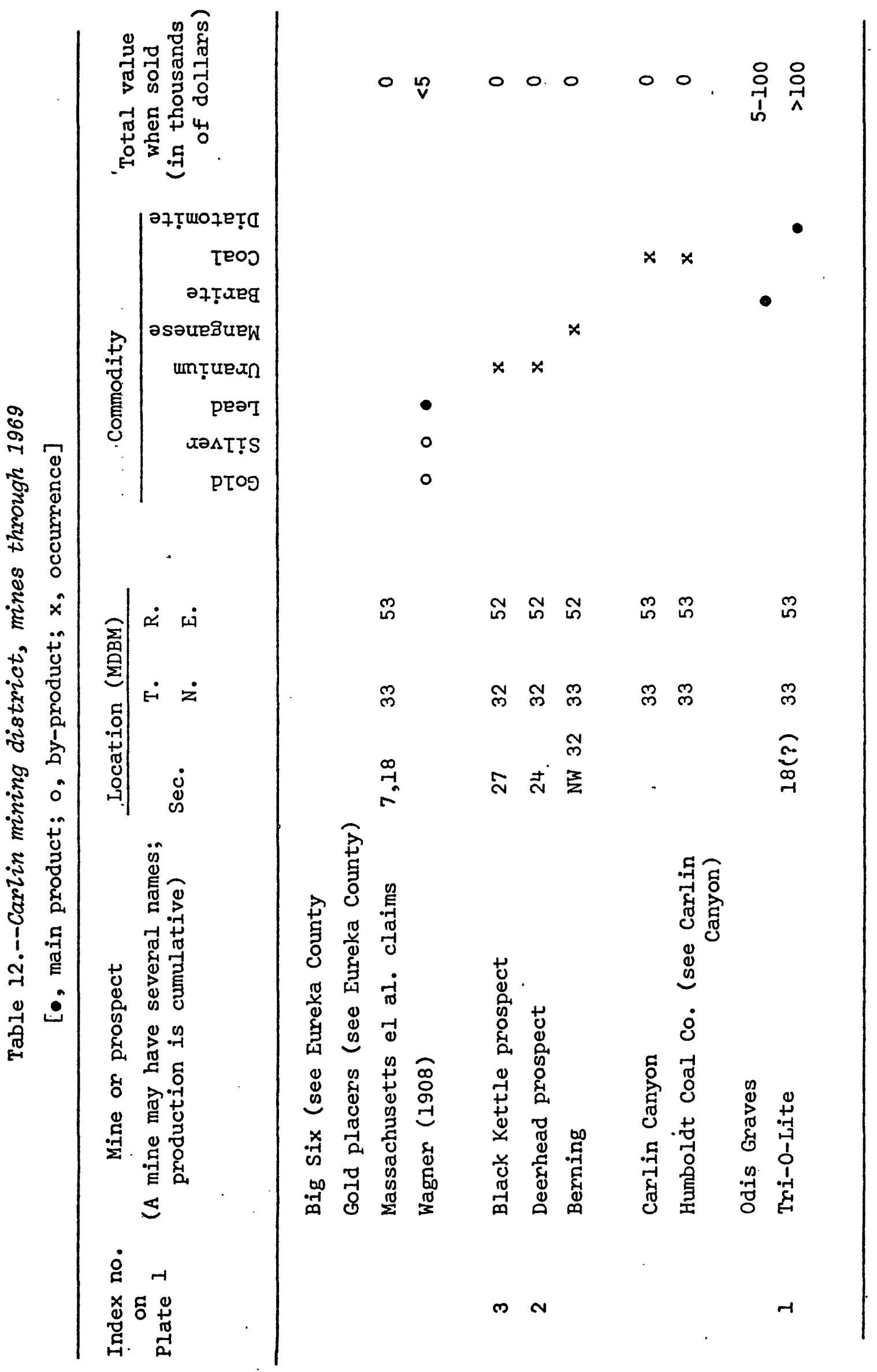


Cave Creek district

Location and history

\begin{tabular}{|c|c|c|c|}
\hline $\begin{array}{l}\text { Sections } \\
\text { (Approx.) }\end{array}$ & & $\begin{array}{l}\text { R. } \\
\text { E. }\end{array}$ & $\begin{array}{l}\text { Quadrangle name } \\
\text { ( } 7 \frac{1}{2} \text { or } 15 \text { minute) }\end{array}$ \\
\hline 2 & 27 & 57 & herman Mountain \\
\hline
\end{tabular}

The Cave Creek district is 12 miles north of Fort Ruby, on the eastern slope of the Ruby Mountains, near the summit (White, 1871, p. 62).

"The cave was discovered in the 1850's and explored during the 1860's by a group of soldiers stationed at Fort Ruby. These men went into the cave in a rowboat; the boat capsized and one of the soldiers was drowned. The Cave Creek Mining District was discovered by General Ewing and recorded in 1869." (Patterson, 1964, p. 18).

Lead, copper, and silver minerals were discovered, and 10 or more claims were staked on three(?) veins 6-10 ft wide that strike north in an area a mile wide and 3 miles long. Very little work was done, and no production has been reported.

The exact location of the veins is not known, but Cave Creek issues from a cave in limestone of the Devils Gate Formation of Devonian age at . an altitude of about 6,200 ft.

\section{Charleston district}

Location and history

\begin{tabular}{|c|c|c|c|c|c|}
\hline $\begin{array}{l}\text { Sections } \\
\text { (Approx.) }\end{array}$ & $\begin{array}{l}\mathrm{T} . \\
\mathrm{N} .\end{array}$ & $\begin{array}{l}\text { R: } \\
\text { E. }\end{array}$ & $\begin{array}{l}\text { Quadrangle name } \\
\text { ( } 7 \frac{1}{2} \text { or } 15 \text { minute) }\end{array}$ & Other district names & . \\
\hline All & 45 & 57 & Rowland, Jarbidge & Mardis, Copper Mountain & \\
\hline $\mathrm{SW}^{1} \frac{1}{4}$ & 45 & 58 & Jarbidge & Copper Basin area & \\
\hline$E-1 / 3$ & 44 & 56 & Mt. Velma & Wyoming, Cornwall Basin & \\
\hline All & 44 & 57 & Mt. Velma & Brumeau, Mardis & \\
\hline$W-1 / 3$ & 44 & 58 & Marys River Bas in NW & Mard is & \\
\hline$N-1 / 3$ & 43 & 57 & Mt. Velma & Bruneau & \\
\hline
\end{tabular}

The Charleston district includes the drainage area of the Bruneau River and its tributaries from Dry Creek $1 \frac{1}{2}$ miles south of Charleston to Coon Creek about 1 miles north, but excludes the Coon Creek tungsten mine which is in the Jarbidge district and the St. Elmo mine on Cornwall Mountain which is in the Island Mountain district. Land Office records are listed under Mardis (Wyoming) district. The old Wyoming district is mostly in Island Mountain district. 
The earliest discovery in the area was the Bruno district "east of Bruno Creek, joining Wyoming. It was discovered in 1864, and organized in 1869, and is fifteen miles square" (White, 1871, p. 59). The principal mine was the Young America gold-bearing ledge located in 1869. Placer gold discovered along Seventy-six Creek, presumably in 1876, led to the organization of the Mardis district and the founding, of the town of Charleston 4 miles south of the placers.

Later discoveries of other placers along several miles of the Bruneau River and its tributaries (Badger, Union, Pennsylvania, and Dry Creeks) and of lode deposits on Copper Mountain extended the district southward to Dry Creek and northward to about Coon Creek. Schrader (1923, p. 81) reported that the Buck Creek Mountains and Bearpaw Mountain north of Coon Creek were included in the district, but they are now included in the Alder and Gold Bas in districts, respectively.

According to Vanderburg (1936, p. 71), "The bed of 76 Creek produced considerable gold in the years following the discovery of placer gold." Johnson (1973, p. 14) estimated "that about 300 oz of placer gold was probably recovered prior to 1900" from the district, and an additiona? $141 \mathrm{oz}$ since 1901. Schrader (1923, p. 82) reported "a small production" of gold, silver, copper, and antimony from the Graham, Prunty, and other lode mines from 1905 to 1920. Production for 1936-38 is recorded under Mardis district. Part of the production from mines listed in table 13 has evidently been credited to other districts. No production was reported for the years 1946-69.

\section{Geologic setting and ore deposits}

The oldest rock formation exposed in the district is in sec. 25, T. 45 N., R. 57 E., where an outcrop half a mile across of schist, quartzite, and hornfels of Precambrian(?) age is in fault contact with Prospect Mountain(?) Quartzite of Cambrian age, which forms Copper Mountain. A few small areas of hornfels, phyllites, and limestones of younger Paleozoic age crop out at lower altitudes around Copper Mountain. These formations are gently to tightly folded or are overturned, are cut by many steep normal faults and by the Copper Mountain thrust fault of Late Mesozoic age, and they are intruded by the Coffee Pot stock, about 11 miles long from east to west, of quartz monzonite of Cretaceous age. Only the southern. edge of the stock is included in the Charleston district. Near the stock the limestones are recrystallized and locally contain tremolite and other skarn minerals. Overlying parts of these formations are flows as much as 2,000 ft thick of Jarbidge Rhyolite of Tertiary age and beds nearly $800 \mathrm{ft}$ thick of Young America Gravel of somewhat younger Tertiary age (Bushnell, 1967, pl. 1; Coats, 1964, pl. 11. The rhyolite but not the gravel is cut by many steep faults, but unlike those in the adjoining Jarbidge district, they are not mineralized. 


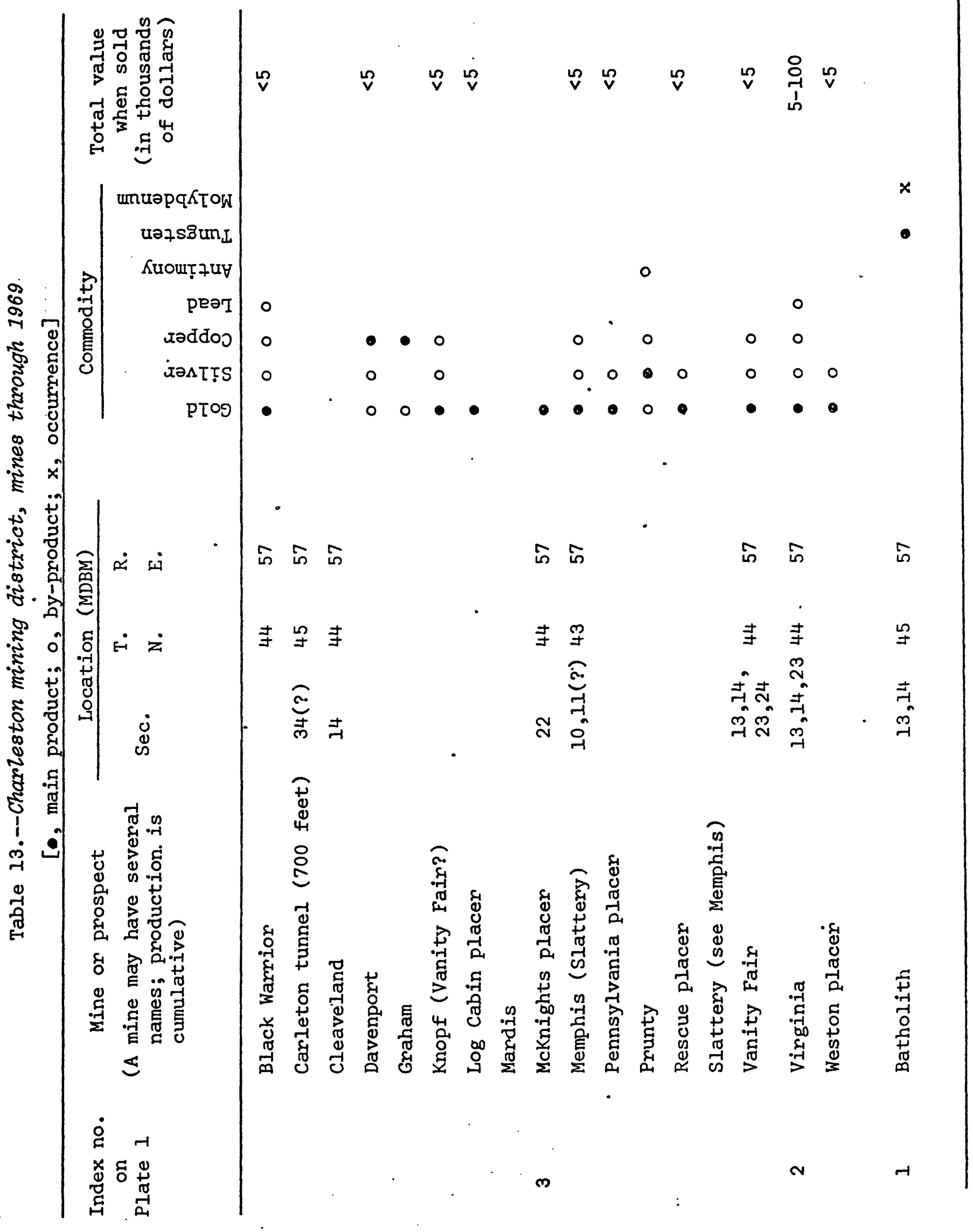


Small deposits of gold, copper, gold-silver, copper-silver, tungsten, and antimony have been mined or prospected. The largest and highest grade lode deposits were mined at the Virginia mine where about 450 tons averaged $2.8 \mathrm{oz}$ gold and $2.3 \mathrm{oz}$ silver per ton. The ore also contained about 0.74 percent copper and 3.7 percent lead. At the Batholith tungsten mine, scheelite occurs with molybdenite and powellite in a contact metasomatic deposit. No production of tungsten has been officially recorded.

Placer gold deposits as much as 50 feet thick contain rather fine gold in gravels composed of well-rounded pebbles of rhyolite and snaller amounts of quartzite and granite. Vanderburg (1936, p. 72) noted their similarity to Mountain City placers, and Schrader (1923, p. 83) observed, "Their occurrence and origin are of more than passing interest, as the adjoining Jarbidge district, with its numerous gold veins, has not yielded any placers."

Coal Mine district

Location and history

\begin{tabular}{llllll}
\hline $\begin{array}{l}\text { Sections } \\
\text { (Approx.) }\end{array}$ & $\begin{array}{l}\text { T. } \\
\text { N. }\end{array}$ & $\begin{array}{l}\text { E. } \\
\text { E. }\end{array}$ & $\begin{array}{c}\text { Quadrangle name } \\
\left(7 \frac{1}{2} \text { or } 15 \text { minute }\right)\end{array}$ & Remarks \\
\hline All & 38 & 56 & N. Fork $4 \mathrm{NW}$ & Coal Canyon mine, phospinate prospects \\
$\mathrm{N}^{\frac{1}{2}}$ & 37 & 56 & N. Fork $4 \mathrm{NW}$ & $\cdot$ Coal Mine Canyon prospects \\
\hline
\end{tabular}

The Coal Mine district includes both sides of Coal Mine Canyon in the north end of the Adobe Range, about 25 miles north and a little east of Elko. The Coal Canyon mine is a prospect shaft on a stratum of oil siale of unknown thickness that is inferred (Ketner, 1970, p. B108) to underlie nearly all the major valleys in the Elko-Coal Mine Canyon area. The oil-bearing stratum. is part of the Chainman Shale Formation of Mississippian age wich is of regional extent.

The coal mine for which the canyon was named was probable on a bed of lignite in the Elko Formation in sec. 12, T. $37 \mathrm{~N}$, , R 56 E. The remains of a tipple and a waste dump were recognizable in 1959 ( $R$. R. Coats, oral commun., 1975 ).

Phosphate deposits have been identified within the district. These deposits and others in the southern Adobe Range (Elko district, T. 34 N., R. 54 E.) and in the Peko Hills (T. 37 N., R. 58 E.) were described by Ketner (1970, p. B108) as follows:

"Permian rocks in the southern and northern Adobe Fañe and in the Peko Hills are significantly phosphatic. Outcrops =f chert, siltstone, and limestone in these areas contain $5:=11$ percentages of phosphate, and concealed thin beds of very ghosphatic rock are indicated by loose pieces scattered on the surface. Analyzed selected samples from the soldthern Alobe Range contained

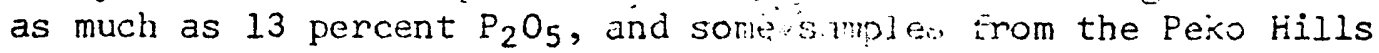


contained about 20 percent. Because the richly phosphatic beds fail to crop out, their extent and thickness can be determined only after exploratory trenching in areas where loose pieces are found."

The general geology of phosphate deposits is summarized herein under Pequop phosphate area.

\section{Contact district}

Location and history

\begin{tabular}{|c|c|c|c|c|}
\hline $\begin{array}{l}\text { Sections } \\
\text { (Approx.) }\end{array}$ & $\begin{array}{l}\text { T. } \\
\text { N. }\end{array}$ & $\begin{array}{l}\text { R. } \\
\text { E. }\end{array}$ & $\begin{array}{l}\text { Quadrangle name } \\
\text { ( } 7 \frac{1}{2} \text { or } 15 \text { minute) }\end{array}$ & Other district names, remarks \\
\hline All & 45 & 63 & Contact. & Salmon, Salmon River \\
\hline AII & 45 & 64 & Contact, Delaplain & Salmon, Salmon River \\
\hline All & 45 & 65 & Delaplain, Texas Spring & Kit Carson, Alabama \\
\hline$W^{\frac{1}{2}}$ & . 45 & 66 & Delaplain, Texas Spring & \\
\hline $\mathrm{N}^{\frac{1}{2}}$ & 44 & 63 & Henry & \\
\hline All & 44 & 64 & Henry, Blanchard Mtn. & $\begin{array}{l}\left.\text { Salmon River ( } N^{\frac{1}{2}}\right) \\
\text { Porter (Portis) ( } \mathrm{S}^{\frac{1}{2}} \text { ) }\end{array}$ \\
\hline AII & 44 & 65 & $\begin{array}{l}\text { Blanchard Mtn., } \\
\text { Texas Spring }\end{array}$ & \\
\hline$W \frac{1}{2}$ & 44 & 66 & $\begin{array}{l}\text { Texas Spring, Delano. } \\
\text { Mountains }\end{array}$ & (Uranium prospects) \\
\hline$N^{1} \frac{1}{2}$ & 43 & 65 & $\begin{array}{l}\text { Blanchard Mtn., } \\
\text { Texas Spring, } \\
\text { Knoll Mtn., } \\
\text { Knoll Mtn. SE }\end{array}$ & Alabama (?) \\
\hline
\end{tabular}

Although a mining claim was staked in 1870, the first mining distric:s to be organized were the Alabama in 1871 and the Salmon and Kit Carson in 1872. When the Salmon River district was organized in 1909 it included 35 townships (T. 41-47 N., R. 63-67 E.). By 1910 the Contact district was considered to be about 20 miles square from Knoll Creek on the south to San Jacinto on the north, and from Bad Lands on the west to Tijuana John. Peak on the east (Schrader, 1912, pl. XIV). This area includes all of the granodiorite stock and all of the surrounding sedimentary rocks in contac: with it in which ore deposits have been found. Land office records for the area are listed under Kit Carson, Porter, and Salmon River districts.

Nearly half the production from the district was made during 1952-57, most of it from the Marshall (Nevada-Bellevue) mine. No production was reported during 1958-69 (table 14).

Barite of high purity and specific gravity (4.20) was shipped from the district in 1956, and the Jungo claims were explored by the American Colloid Company in 1957. 


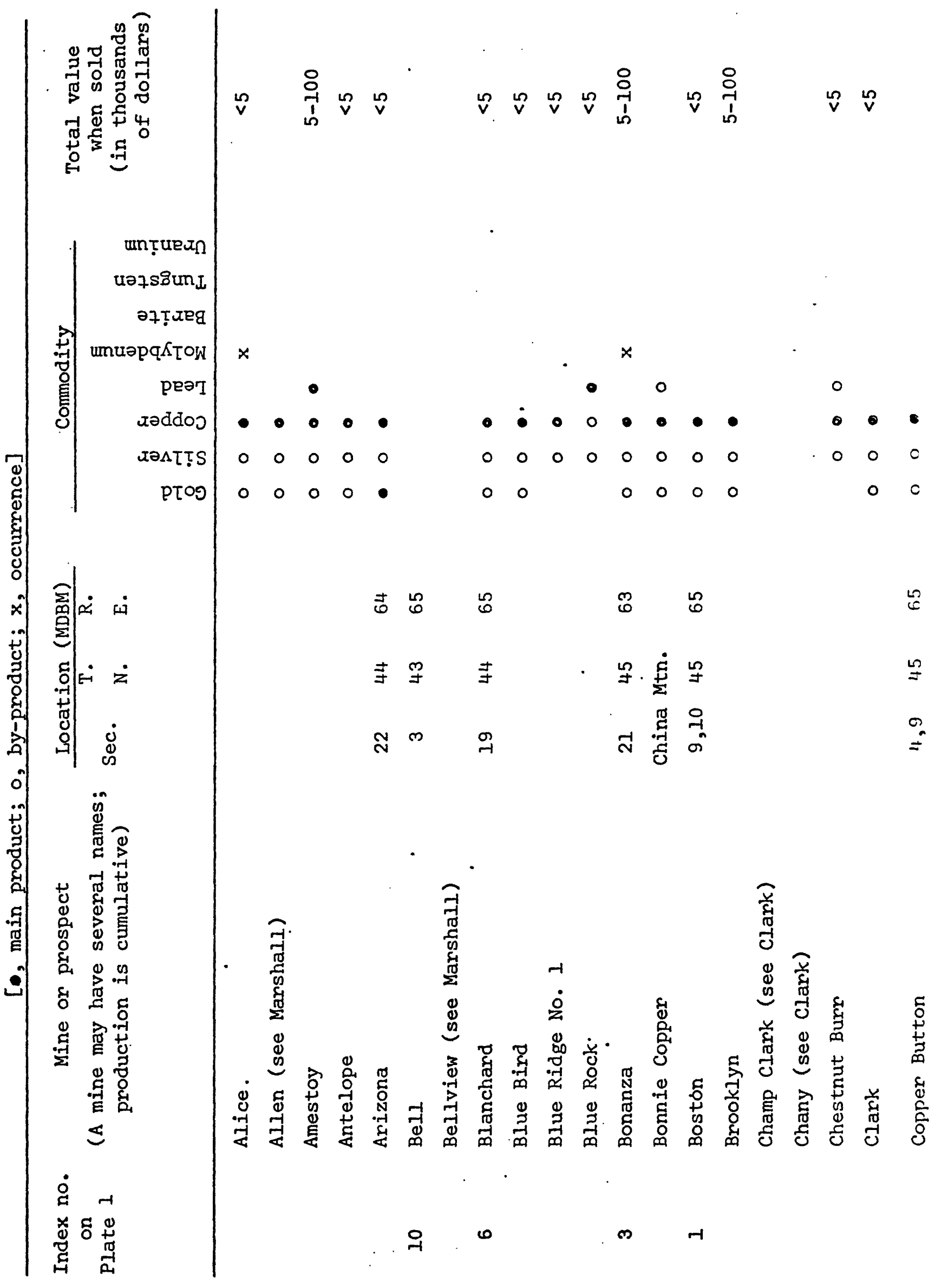




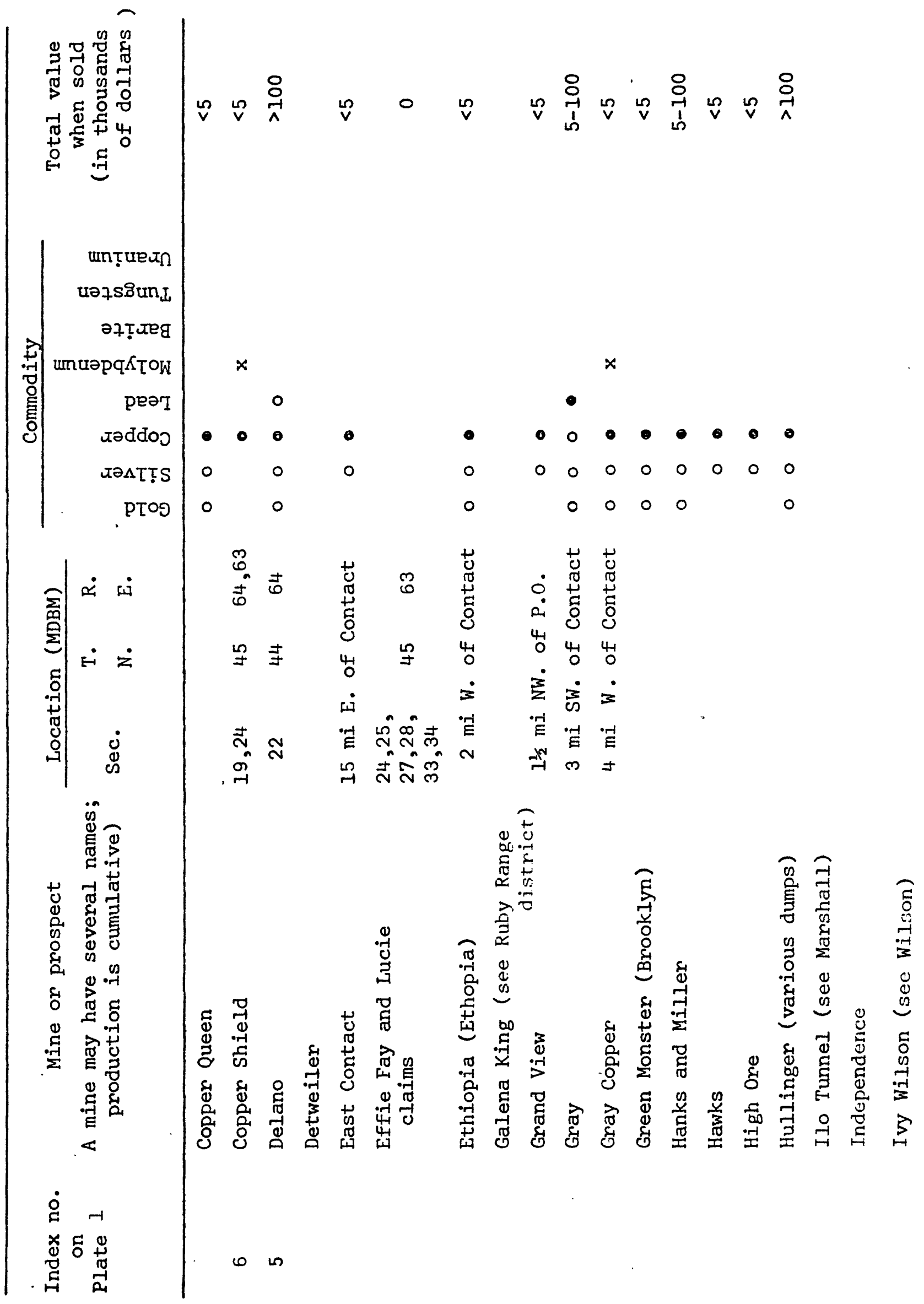




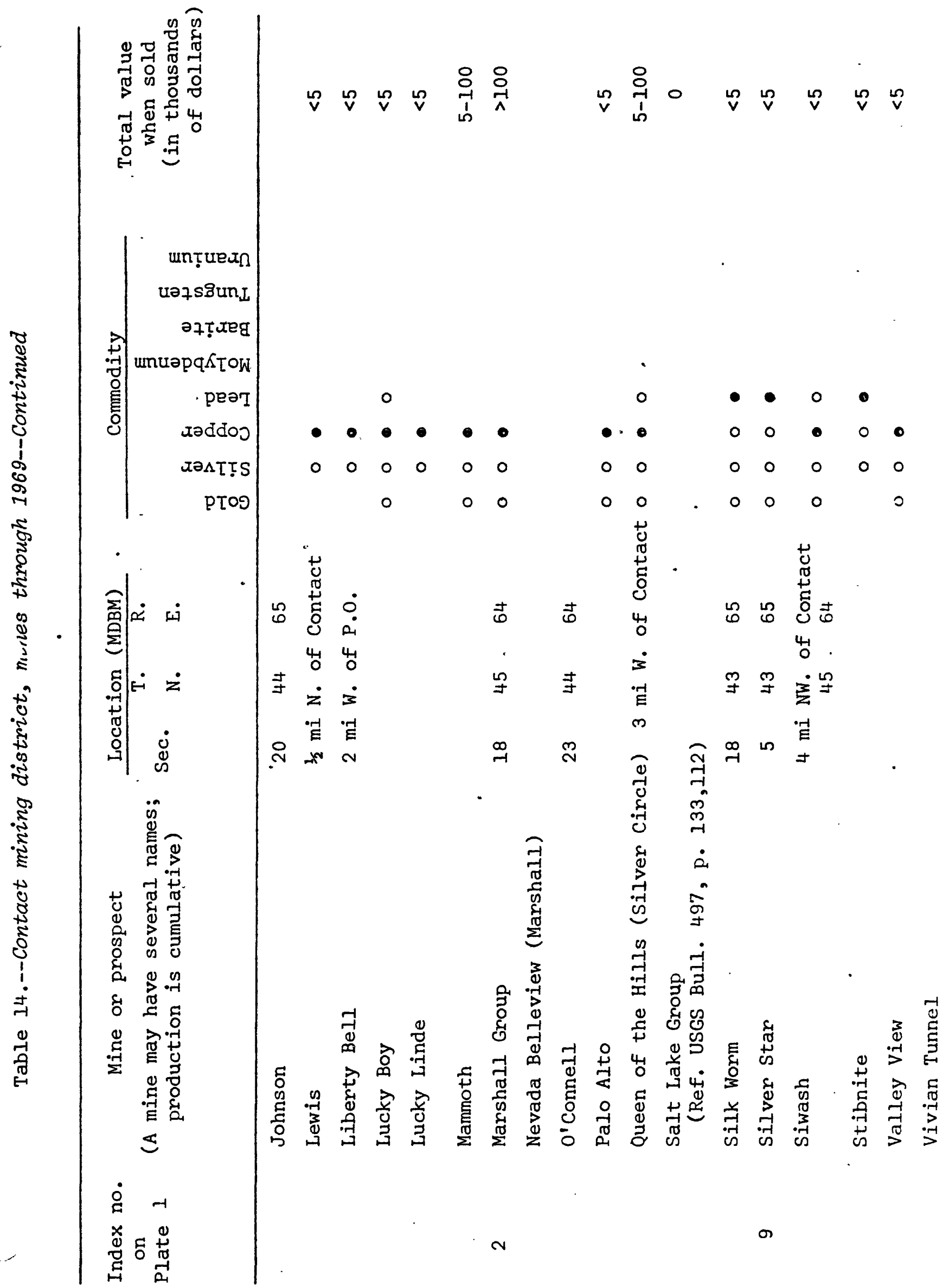


The Silver Star property was explored during 1972 by Sunshine Mining Co., Kellogg, Idaho, by diamond drilling. Vein intercepts of 20-60 ft were reported, one of which assayed $22.3 \mathrm{oz}$ silver per ton over a width of $25 \mathrm{ft}$ (Eng. Mining Jour., July 1972, p. 134).

Calta Mines Ltd. reported over 8 million tons of blocked-out ore averaging 2.3 percent copper near Contact (Eng. Mining Jour., April 1973).

Geologic setting and ore deposits

The oldest rock in the district is Carboniferous quartzite about $200 \mathrm{ft}$ thick. It is overlain by shaly quartzite, shale, black limestone, quartzite, and blue, white, and gray limestones totaling about 1,400 ft thick of Carboniferous(?) age.

The sedimentary rocks are domed and variously tilted, folded, and brecciated around an intrusive stock of Jurassic granodiorite 16 miles long from east to west and 8 miles wide. Concealed portions of the stock are doubtless much larger. Within 2,000 ft of the contact the limestones are locally altered to tactite, and some of the shale to slate and hornfels.

The granodiorite and the sedimentary rocks are cut by faults that strike northeast, northwest, or are parallel with the contact, and dip steeply. Some of the faults of the first two sets contain dikes--a few older basic dikes up to $8 \mathrm{ft}$ wide, and numerous younger siliceous dikes as much as $200 \mathrm{ft}$ wide and 5 miles long. Other faults, as well as some of the dikes and also parts of the contact, contain quartz veins as much as. $18 \mathrm{ft}$ wide.

The foregoing assemblage is unconformably overlain by rhyolite flows and tuffs about $200 \mathrm{ft}$ thick of Miocene age which correspond to the younger volcanics of the general region. A few erosion remnants of these rhyolites cap small areas of the granodiorite. Parts of the volcanic rocks and all older strata are unconformably overlain by sandstone lake beds as much as $400 \mathrm{ft}$ thick of the Humboldt. Formation of Pliocene age. Recent stream beds and valleys contain Quaternary alluvium.

Ore deposits of two genetic types have been mined, quartz veins along faults, dikes, and the granodiorite contact, and contact metamorphic deposits in the metasedimentary rocks near the intrusive.

The largest ore bodies mined were in quartz veins along the contact (Nevada-Bellevue mine) on the north side of the granodiorite near its west end. Other smaller ore bodies were mined along the north side near $I, \varepsilon$ ? (Ellen D.) and Middle Stack Mountains, along the south side near China and $\mathrm{Blanchard} \mathrm{Mountains,} \mathrm{in} \mathrm{the} \mathrm{granodiorite} \mathrm{mostly} \mathrm{near} \mathrm{its} \mathrm{west} \mathrm{end,}$ and in the sedimentary rocks south of the stock near Knoll Mountain.

In the quartz veins, which are as much as 10,000 ft long and pinch and swell from a few inches to about $18 \mathrm{ft}$ wide, ore shoots up to $10 \mathrm{ft}$ wire extending as much as $500 \mathrm{ft}$ along the strike have been mined down the dif for 400 . ft or less. 
Ore minerals in the vein deposits are chalcopyrite, smaller amounts of bornite, and locally galena, sphalerite, molybdenite, argentite, and gold, but to depths of 150-250 ft much of the sulfide ore is oxidized to malachite, chrysocolla, azurite, cuprite, native copper, covellite, chalcocite, cerussite, anglesite, and probably cerargyrite.

Average grade of all production recorded was nearly 4 percent copper, $0.18 \mathrm{oz}$ gold per ton, and $1.5 \mathrm{oz}$ silver per ton, but some small vein ore shoots contained nearly 50 percent copper. Some lead-silver ores contained 18 percent lead, 3 percent zinc, and $12 \mathrm{oz}$ silver per ton, although much higher grades were also reported.

Contact metamorphic deposits of copper sulfides and oxides in a gangue of garnet, axinite, chloropal, epidote, calcite, quartz, actinolite, diopside, and iron oxides are in general rather small, perhaps $10-25 \mathrm{ft}$ across, and have yielded only a few hundred tons of ore. Some of the ores contained 7-8 percent copper, 8-38 oz silver per ton, and a little gold. At least one contact metamorphic deposit was mined for its tungsten content (Tunnel mine, table 14). Schrader (1912, p. 113) reported the occurrence of allanite as a minor accessory mineral in the contact zone.

Autunite and other uranium minerals occur in thin stringers along the bedding of tuffaceous lake sediments at the Pink Horse claims (table 14), and in brecciated limestone near the intersection of two faults at the Prince \#1 prospect. Selected samples assayed over 1 percent $\mathrm{U}_{3} \mathrm{O}_{8}$, but the average grade is less than 0.2 percent $\mathrm{U}_{3} \mathrm{O}_{8}$.

Cornucopia district

Location and history

\begin{tabular}{llll}
\hline $\begin{array}{l}\text { Sections } \\
\text { (Approx.) }\end{array}$ & $\begin{array}{l}\text { T. } \\
\text { N. }\end{array}$ & E. & $\begin{array}{l}\text { Quadrangle name } \\
\left(7 \frac{1}{2} \text { or } 15 \text { minute }\right)\end{array}$ \\
\hline$W^{1 / \frac{2}{2}}$ & 42 & 51 & Wilson Reservoir \\
\hline
\end{tabular}

According to Thompson and west (1881, p. 393), silver ores were discovered and the district was organized in 1872. "The excitement incident to the discovery of the district caused the building of the town of Comucopia, which at one time, in 1874, was quite lively and contained about 1,000 inhabitants." The Leopard Mining Company built "first a 10-stamp mile which was consumed by fire and replaced by a twenty-stamp mill **** which was likewise destroyed" in 1880 , whereupon the population dwindled to 174 . No production has been reported since 1882 except from 10,000 tons of old mill tailings during 1937-40 (table 15).

There are two principal mines in the district, the Leopard (Cornucopia) which was the larger, and the Panther. The Lcopard shaft was said to be son ft deep, but the deep workings are caved (Emmons, 1910, p. 62). The Leopard vein was worked extensively in an area now covered by mine dumps (Coats, 1967, p. 3). The Panther vein was stoped in two areas about $700 \mathrm{ft}$ apart (Enmons, 1910, fig. 5). 


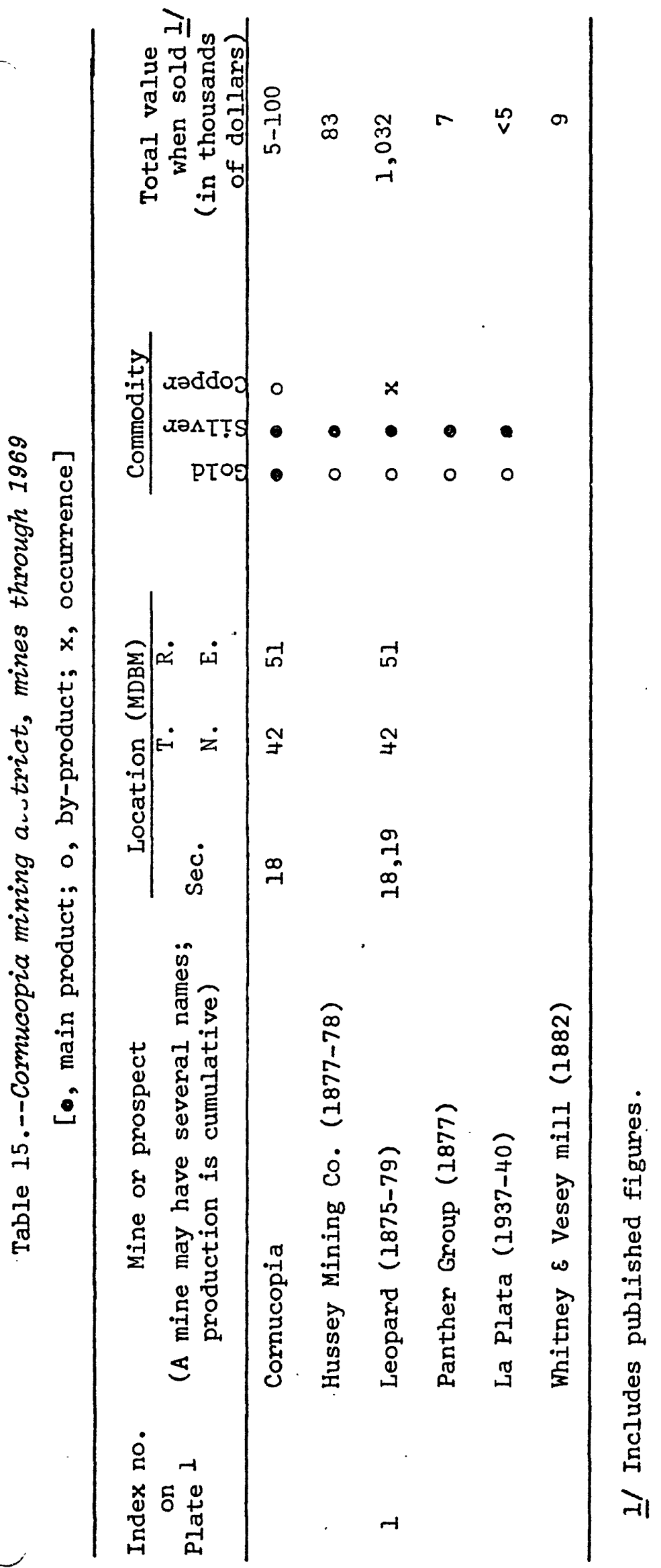


Surface chip-sampling during 1973 indicated disseminated gold-silver mineralization over a broad area in the vicinity of the Leopard vein (Eng. Mining Jour., June 1974, p. 19). Exploration by trenching during 1974 indicated that drilling is warranted in an area east of the Leopard shaft, and that open-pit mining may be feasible (Eng. Mining Jour., March 1974 , p. 230 ).

\section{Geologic setting and ore deposits}

The oldest rocks that crop out in the district are rhyolite tuff and andesite flows of probable Eocene age. They are overlain by, or are in fault contact with, andesite porphyry flows and rhyolite flows of Miocene age. The andesite porphyry is overlain unconformably by a series of rhyolite tuff, rhyolite welded tuff, and rhyodacite tuff layers of later Miocene age.

The andesite porphyry and older rocks are cut by four sets of faults that dip steeply or are vertical: one set strikes north, another east, a third strikes northeast, and the fourth northwest. Some faults of all sets also cut the younger rhyolitic tuffs.

The ore deposits that were mined were found only in the andesite porphyry; the postandesite rhyolite and rhyodacite tuffs are postmineral in age (Coats, $1967, \mathrm{p} .1$ ). The ore bodies are quartz veins in sheeted zones of highly altered andesite along all four sets of faults, but the very productive Leopard vein strikes north, and the Panther, eastward. Postmineral movement on silicified faults that strike northwest have displaced these two veins; the Leopard vein is cut off at the north end, and the Panther vein is cut into segments displaced $100 \mathrm{ft}$ or more. The main ore body in the Panther vein was in a fault segment $60 \mathrm{ft}$ long; widths are no: reported. Numerous prospect pits in an area extending 1,000 ft north of the vein, $500 \mathrm{ft}$ south of it, and about $700 \mathrm{ft}$ from east to west, were evidently not productive.

The ore minerals are cerargyrite and pyromorphite(?) near the surface, and argentite, tetrahedrite, and ruby silver (proustite or pyrargyrite) at greater depths. The sulfides form narrow ribbons in the quartz veins. Gangue minerals are quartz, pyrite, iron oxide, and the alteration minenals, kaolin, silica, sericite, and chlorite.

Average grade of the ore reported by Couch and Carpenter (1943, p. 42) was about $\$ 44$ per ton, but some mill runs were said to have carried $400=2$ of silver to the ton (Emmons, 1910, p. 64). Reworked tailings yielded C.i 3 oz gold and 9 oz silver per ton. 
Corral Creek district

Location and history

\begin{tabular}{|c|c|c|c|c|}
\hline $\begin{array}{l}\text { Sections } \\
\text { (Approx.) }\end{array}$ & & $\begin{array}{l}\text { R. } \\
\text { E. }\end{array}$ & $\begin{array}{l}\text { Quadrangle name } \\
\text { ( } 7 \frac{1}{2} \text { or } 15 \text { minute) }\end{array}$ & Other district names \\
\hline$S^{\frac{1}{2}}$ & 28 & 57 & Jiggs & Ruby Range \\
\hline
\end{tabular}

The Corral 'Creek district on the west slope of the Ruby Mountains about 3 miles southwest of Harrison Pass includes the drainage area of Corral Creek and its tributaries. The Summit View mine and nearby prospects are near a south branch of Corral creek in sec. 21 at altitudes of 7,400-7,800 ft.

The only recorded production from the district was during the years 1948-52 when 108 tons of lead-zinc ore was shipped from the Summit View mine. In table 5 the quantities are included with undistributed production.

\section{Geologic setting and ore deposits}

The Corral Creek district covers part of the contact of upper Cambrian limestones and argillite with Tertiary granodiorite-quartz monzonite of the Harrison Pass stock along its southwest corner. The Surnmit View mine and the Sumit King and other prospects are in the sedimentary rocks near the contact.

A pegmatite dike in the stock near the head of Corral Creek contains lepidolite. Other dikes were examined (Olson and Hinrichs, 1960, p. 171) for beryl, but none was found.

Ore shipped from the district averaged about 2.5 percent lead, 1.1 percent zinc, 0.15 percent copper, and $3.0 \mathrm{oz}$ silver per ton.

\section{Decoy district}

Location and history

\begin{tabular}{lllll}
\hline $\begin{array}{l}\text { Sections } \\
(\text { Approx. })\end{array}$ & T. & R. & Quadrangle name & Remarks \\
$\left(7 \frac{1}{2}\right.$ or 15 minute $)$ & Manganese \\
\hline 6 & 32 & 68 & Shafter $3 \mathrm{NE}$ & Mang \\
\hline
\end{tabular}

The Decoy district covers a small area on the lower west slopes near the center of the Toano Range. Manganese ore, the only commodity produced from the district, was shipped during 1917 and 1918 from the Darkey mine, and during 1952 from the Black Rock mine. Total production is not known but was probably less than 2,000 tons. 
Geologic setting and ore deposits

Limestone and dolomite strata of Ordovician and Silurian ages are generally flat lying and are displaced along steep faults that strike north or east. The manganese ore bodies occur along a north-striking fault and also in limestone adjacent to the fault. The largest of several ore shoots in the Darkey mine was $25 \mathrm{ft}$ long, $8 \mathrm{ft}$ wide, and $60 \mathrm{ft}$ deep. Psilomelane, pyrolusite, and wad were accompanied by quartz, calcite, and limonite. Ore selected for shipment from the Darkey mine contained about 45 percent manganese and less than 5 percent silica (Pardee and Jones, 1920 , p. 24l). Shipments from the Black Rock mine averaged about 28 percent manganese.

Delano district

Location and history

\begin{tabular}{|c|c|c|c|c|}
\hline $\begin{array}{l}\text { Sections } \\
\text { (Approx.) }\end{array}$ & $\begin{array}{l}\text { T. } \\
\text { N. }\end{array}$ & $\begin{array}{l}\text { R. } \\
\text { E. }\end{array}$ & $\begin{array}{l}\text { Quadrangle name } \\
\text { ( } 7 \frac{1}{2} \text { or } 15 \text { minute) }\end{array}$ & Other district names, remarks \\
\hline$S E^{\frac{1}{4}}$ & 45 & 68 & $\begin{array}{l}\text { Goose Creek, } \\
\text { Dairy Valley }\end{array}$ & Prospects \\
\hline All & 44 & 67 & Delano Mountains & Prospects \\
\hline $\mathrm{All}$ & 44 & 68 & $\begin{array}{l}\text { Delano Mountains, } \\
\text { Dairy Valley }\end{array}$ & $\begin{array}{l}\text { Delno district, Goose Creek(?) } \\
\text { district }\end{array}$ \\
\hline$N^{2}-\frac{1}{2}$ & 43 & 67 & Delano Mountains & Prospects \\
\hline$N \frac{1}{2}$ & 43 & 68 & $\begin{array}{l}\text { Delano Mountains, } \\
\text { Dairy Valley }\end{array}$ & $\begin{array}{c}\text { New York district, Mitchell mine } \\
\text { - }\end{array}$ \\
\hline
\end{tabular}

The district covers the north and central parts of the Delano Mountains north of Delano Peak. Near the north end of the range the original Delano district includes the Delno and Cleveland lead-silver mines; in the central part near Indian Springs the former New York district (Lotz, 1934, p. 18) includes the Mitchell silver-copper mine and the Indian Springs tungsten property. In addition to the productive mines, numerous prospects west (Rock Spring Creek) and north of the range are, in this report, included in the district.

The Delano district fits the description by Thompson and West (1881, p. 393) of a Goose Creek district, which was organized in 1872 in the Goose Creek Mountains about 30 miles north of Tecoma to include veins in limestone and porphyry assaying $\$ 160-\$ 350$ per ton.

The Delano district was organized sometime before 1831 (Thompson an? West, 1881, p. 393), and was named in honor of Alanzo Delano- who, in $h$; Overland Journal of 1849, tells of the mineralized area in the Thousand Springs-Goose Creek drainage basins. In local usage, the name Delno has precedence, but Land office records are listed under the Delano mining distri:t.

I/Alanzo Delano was a member of the family from which President Frarklin Delano Roosevelt was descended (Patterson, 1964, p. 25). 
The first recorded production was in 1908 from the Cleveland (44 tons) and Argyle ( 31 tons) mine. Ore was produced during every year from 1917 through 1969 except 1967; maximum annual production was about $\$ 340,000$ in 1948 (Granger and others, 1957, p. 44). Most of the production from the district came from two mines, the Cleveland with $6,700 \mathrm{ft}$ of workings in 1950 and the Delno with 5,900 ft. The latter has also been called the Delano mine (table 16), but all production under the name of Delano for 1911-44--more than $\$ 100,000--$ is credited to the Delano mine in the Contact district. Seven or more tin prospects were discovered during the 1950 's, but no tin has been produced.

Exploration at the Indian Springs tungsten deposit on the Gamble Ranch in 1969 was reported by the Arizona Colorado Land and Cattle Co. to have discovered 17.4 million tons of ore averaging 0.19 percent $\mathrm{WO}_{3}$ (Nevada State Jour., October 5, 1969).

\section{Geologic setting and ore deposits}

In the Delano Mountains, three successively younger sedimentary formations.are tentatively identified and mapped (Slack, 1972, pl. 1) as Pequop, Grandeur, and Phosphoria Formations of Permian age. Near Delano Peak they are intruded by an igneous stock of Cretaceous age, and surrounding the range they are overlain by sedimentary and volcanic rocks of Tertiary age.

The Pequop(?) Formation here consists of three members, a lowermost calcareous sandstone, a middle carbonaceous limestone, and an upper bioclastic limestone and chert which total nearly 4,000 ft in thickness. It is conformably overlain by, or locally is in fault contact with, dolomites containing a few thin beds of limestone and quartzite of the Grandeur member of the Park City Formation which total about 2,500 ft in thickness. The overlying Phosphoria is represented by siltstones, shale, and phosphorite of the Meade Peak member, which is of variable thickness due to low-angle bedding-plane thrust faults, and by massive chert beds of the Rex chert member 2,500-3,000 ft thick.

Low-angle bedding-plane thrust faults, mainly in the Meade Peak member, displaced the Phosphoria Formation eastward over the Grandeur. During the Jurassic Period the Permian strata were gently folded. On the northeast slopes of Delano Peak they were intruded and domed by the Indian Springs stock about a mile wide and nearly 2 miles long (N. $20^{\circ}$ E.) of quartz monzonite porphyry which, in places, grades into other compositions and textures. Minimum age of the stock is about $135 \mathrm{~m} . \mathrm{y}$. or earl iest Cretaceous. Permian strata surrounding the Delano Mountains are overlain unconformably by Jarbidge Rhyolite of Miocene age and by volcanic ash and sediments of the Salt Lake (Idavada?) Formation of Pliocene age. The Salt Lake Formation is overlain by a few small patches less than 1,500 ft across of welded tuff--including perlite--of Pliocene age. 


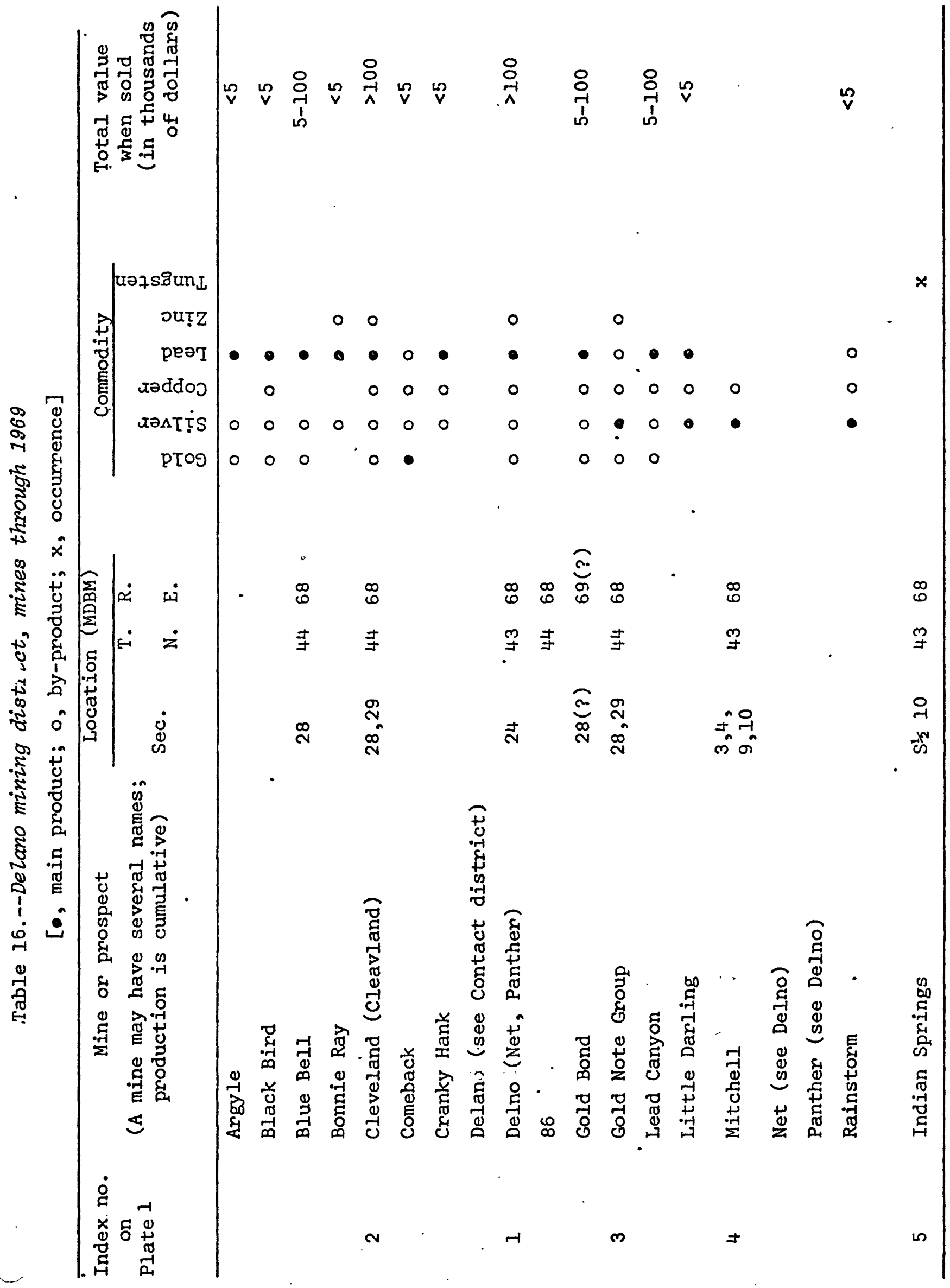


Around the borders of the stock calcareous sandstones and limestones are locally altered to garnet tactite which contains pyrite, chalcopyrite, magnetite, a little scheelite, powellite, and possibly sphalerite, or their oxidation products. The stock and the rocks around it are cut by a network of faults having displacements of a few inches to 1,000 ft or more. Some of the faults are occupied by granitic dikes and others by quartz veins as much as $15 \mathrm{ft}$ wide, most of which strike northeast. Stockworks of quartz veins along the east edge of the stock contain pyrite, magnetite, scheelite, powellite, molybdenite, and a little fluorite, but tungsten production, if any, is not recorded. Other quartz veins contain pyrite, molybdenite, and chalcopyrite, others silver and copper minerals, and still others are barren.

Two types of ore bodies in two separate parts of the district have been mined. In the southern part of the district silver-copper-bearing quartz veins in the stock near its west edge were worked at the Mitchell mine, but production records are not available. In the northern part of the district lead-silver replacement bodies in the Grandeur limestones about 2 miles north of the stock were mined at the Delno, Cleveland, and other mines.

In the Cleveland and Delno mine areas the strata are tilted $20^{\circ}-45^{\circ} \mathrm{W}$. and are cut by four sets of faults. One set is along the bedding, another set dips steeply east or is vertical, and two other sets dip $45^{\circ}$ or more northeast and northwest. The ore bodies in the Cleveland, Delno, and Gold Note mines are replacement deposits along bedding faults in two parallel limestone beds 18 inches to $6 \mathrm{ft}$ thick separated by a partly silicified dolomite stratum 6-8 ft thick. The footwall of the lower bed is Loray(?) sandstone; the hanging wall of the upper bed is blue Grandeur dolomite. Most of the ore came from the upper bed.

Ore shoots in the upper bed were as much as $6 \mathrm{ft}$ thick, $125 \mathrm{ft}$ long, and were mined down the dip for $450 \mathrm{ft}$ in the Cleveland mine and 1,700 ft in the Delno mine. They are displaced by faults which offset the beds a few feet to $65 \mathrm{ft}$, and also apparently control the lateral limits of the ore (Granger and others, 1957, p. 48, figs. 7 and 8). Ore minerals are cerussite, galena, bindheimite, unjdentified silver minerals, and minor amounts of anglesite, sphalerite, argentite, tetrahedrite, and malachite. Cerussite is more abundant than galena even on the deepest levels. The gangue is amorphous silica, jasper, and iron oxides.

Average grade of all the ore mined through 1969 was gold $0.004 \mathrm{oz} /$ ton, silver $21 \mathrm{oz} / \mathrm{ton}$, copper 0.1 percent, lead 13.1 percent, and zinc (1950-69) 1.9 percent.

Tin deposits were found near the Cleveland mine in the same stratigraphic horizon, and also in lower horizons of the Grandeur member in an area extending 1,600 ft east, $800 \mathrm{ft}$ north, and 2,400 ft south of the mine (Olson, 1960, pl. 4). A tin-bearing(?) mineral was also found in veins(?) in silicified sedimentary rocks north of the rhyolite porphyry $2 \frac{1}{2}-8$ miles east of the mine, and possibly in the porphyry itself (0lson, 1960, p. 80,44). The tin occurs with unidentified silver minerals as fine-grained cassiterite(?) in yellow earthy stringers in brecciated veins of quartz and jasper healed 
with chalcedony and opal along bedding faults in shaly limestone. At the deposit 1,800 ft southeast of the Cleveland shaft, the tin-bearing vein is $2 \mathrm{ft}$ thick between layers of iron oxide 6-18 inches thick. Selected specimens contained as much as 2 percent tin. A channel sample across the vein and another across the iron oxide layer on the footwall each assayed 0.66 percent tin; the hanging wall layer of iron oxide contained 0.33 percent tin.

The source of both the $t$ in and the lead-silver mineralizing solutions is considered by Slack (1972, p. 138) to be the Early Pliocene(?) rhyolite porphyry "intrusives(?)" exposed in the area of Granite and Mill Creeks. He rejected the possibility of a zonal relationship of the lead-silver deposits to the Indian Springs stock. A third possible source could be a concealed intrusive near the lead-silver deposits.

\section{Delker district}

Location and history

\begin{tabular}{lllll}
\hline Sections & T. & R. & Quadrangle name & Other district names \\
(Approx.) & N. & E. & "Elko $2^{\circ}$ & Delkar district \\
\hline$W^{\frac{1}{2}}$ & 29 & 62 & El &
\end{tabular}

The Delker district covers all of West Buttes (Delker Hill), an isolated

- north-trending ridge 7 miles long which is 3 miles east of Delcer. Buttes and rises about 1,600 ft above Dry Lake Flat east of Franklin Lake. Both buttes were called Franklin Buttes by geologists of the Fortieth Parallel Survey, and both were later known as Delker Buttes (Hill, 1916, p. 66).

Copper ores were first discovered about 1894 near the north end of Delker Hill, and a little prospecting was done annually thereafter. The only production records are for 1916 and 1917 when 791 tons containing 94,434 Ib of copper was shipped from the Delker (Copper Belt, Delkar) mine.

Geologic setting and ore deposits

Limestones and interbedded quartzites of the Permian Park City Group are intruded by quartz monzonite which is porphyritic in many places and which forms the main bulk of West Buttes and Delcer Buttes. The exposed limestones are diversely metamorphosed; lime silicate zones are developed along parts of the contacts with the intrusive rocks.

The ore bodies that have been mined and prospected are contact metamorphic copper deposits. "Chrysocolla, malachite, azurite, and minor chalcocite occur with lime silicate minerals and jasperoid near the contacts and also in a few veinlike deposits along fractures in the intrusive (Hill, 1916, p. 67). Average grade of the ore shipped was 6.2 percent copper. 
Divide district

Location and history

\begin{tabular}{|c|c|c|c|}
\hline $\begin{array}{l}\text { Sections } \\
\text { (Approx.) }\end{array}$ & & $\begin{array}{l}\text { R. } \\
\text { E. }\end{array}$ & $\begin{array}{l}\text { Quadrangle name } \\
\text { ( } 7 \frac{1}{2} \text { or } 15 \text { minute) }\end{array}$ \\
\hline $\mathrm{N} \frac{1}{2}$ & 40 & 50 & Mt. Blitzen \\
\hline
\end{tabular}

The Divide district covers the drainage divide of the Tuscarora Mountains for about 4 miles northwest of MCCann Creek Mountain. The Divide mine, the only mine in the district, is on the east slope near the summit of the range 8 miles airline northwest of the town of Tuscarora. A small production of silver-gold ore was reported for 1918. Subsequent production in 1929 was recorded for a Divide mine in the Rock Creek district, but in this report it is credited to the Divide district. Total value for both years is less then $\$ 5,000$.

Average grade of the total production was about $0.46 \mathrm{oz}$ gold and 291 oz silver per ton.

Dolly Varden district

Location and history

\begin{tabular}{|c|c|c|c|c|}
\hline $\begin{array}{l}\text { Sections } \\
\text { (Approx.) }\end{array}$ & $\begin{array}{l}\mathrm{T} . \\
\mathrm{N} .\end{array}$ & $\begin{array}{l}\text { R. } \\
\text { E. }\end{array}$ & Quadrangle name & Other district names \\
\hline$S-1 / 3$ & 30 & 66 & Elko $2^{\circ}$ & \\
\hline$E-1 / 3$ & 29 & 65 & Elko $2^{\circ}$ & \\
\hline AlI & 29 & 66 & Elko $2^{\circ}$ & Mizpah \\
\hline $\begin{array}{l}29,30, \\
31,32\end{array}$ & 29 & 67 & Elko $2^{\circ}$ & Dolly Varden \\
\hline$E-1 / 3$ & 28 & 65 & Elko $2^{\circ}$ & \\
\hline All & 28 & 66 & Elko $2^{\circ}$ & Granite, Granite Mountain \\
\hline$W^{3} / 2$ & 28 & 67 & Elko $2^{\circ}$ & Dolly Varden \\
\hline
\end{tabular}

The district covers all of the Dolly Varden Mountains, about 14 miles long from north to south and 11 miles wide, including many small outcrops of intrusive rock in the lower foothills on the east side. Land office records are listed under Granite Mountain district.

Silver-lead ores were discovered near Dolly Varden (Hicks, Last Chance) Spring in the southeastern part of the district in 1869 (Hill, 1916, p. 80), copper ore at the Victoria mine in 1872, and gold-bearing veins near Mizpah Spring in 1905. Intermittent production was reported during the $1870^{\prime} \mathrm{s}$, 1908-45, and in 1956, most of which came from the Victoria mine during 1941-45. No production was reported for the years 1957 through 1969 . 
During 1973, the Victoria mine was being developed by The Anaconda Company as an open pit. A concentrator to treat 1,000 tons of copper-goldsilver-bismuth ore per day was scheduled for completion in 1975. Concentrates will be shipped to Anaconda, Mont., where a hydrometallurgical plant will treat the high-bismuth ores by the Arbiter process.

\section{Geologic setting and ore deposits}

Limestone and limy and cherty shales of the Pequop Formation overlain by two small erosion remnants of limestone of the Park City Group, all of Permian age, are intruded by a stock about 4 miles across of quartz monzonite and by dikes as much as half a mile wide and 2 miles long of quartz monzonite, aplite, and diorite. Southeast of the stock in the southeast foothills small outcrops of quartz monzonite indicate a second stock mostly covered by Tertiary volcanics and alluvium. Near the main stock the limestones are metamorphosed to skann and the shales to argillite.

The sedimentary and intrusive rocks are tilted gently to moderately eastward and displaced along two north-trending thrust faults and along many steep normal faults which strike generally northward or eastward.

Of the three types of ore bodies mined--copper ores in contact metamorphic rocks, lead-silver replacement and fissure deposits in limestone, and gold-bearing quartz veins in quartz monzonite--the copper deposits at the Victoria mine were the largest (table 17).

All the copper deposits are near the main stock, but their size and shape were not reported. Chrysocolla, malachite, a little chalcocite, and residual chalcopyrite and bornite occur in a gangue of jasperoid, quartz, garnet, biotite, tremolite, actinolite, epidote, calcite, much limonite, and a little pyrite.

Average grade of the ore shipped was about 6 percent copper. The outcrop area of highly altered quartz monzonite resembling a leached porphyry copper reported by Hill (1916, p. 82, 87) may be the Red Hill prospect (table 17). The Victoria copper deposit to be mined by Anaconda is reported (Nevada Mining Assoc. Newsletter, July 15, 1973) to contain 3.5 million tons averaging 2.45 percent copper.

Lead-silver deposits are localized along north-striking fractures in the limestone and in irregular replacements along the bedding adjacent to the fractures. Argentiferous cerussite, anglesite, a little wulfenite, and residual kemels of galena occur with limonite and residual pyrite.

Gold occurs with chalcopyrite, pyrite, bornite, bismuthinite, and their oxidation products, in quartz veins a few inches to. $2 \mathrm{ft}$ wide along steep northward-trending fractures in the quartz monzonite east of Mizpah Spring.

Thorium and a little uranium occur with iron oxides, and in at least one place with chrysocolla, along fractures in pegmatite, in rhyolite, in quartz monzonite, and in the contact metamorphic zone of the main stock. A sample contained the following percentages: thorium, $5.95 ; \mathrm{eU}_{3} \mathrm{O}_{8}, 1.5$; $\mathrm{CU}_{3} \mathrm{O}_{8}, 0.128$; rare earth oxides, 0.35 (Davis, 1954, p. 17). 


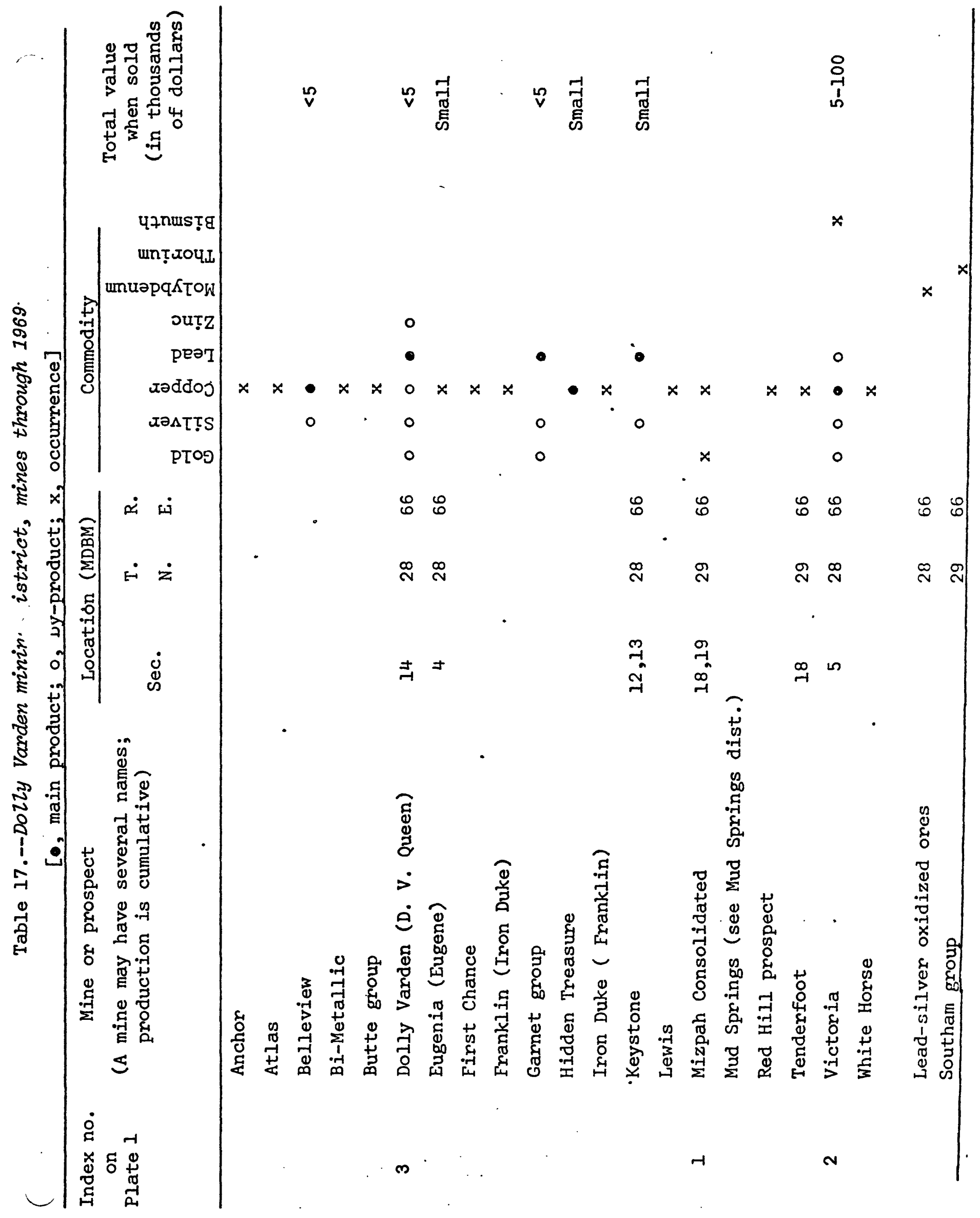


Edgemont district

Location and history

\begin{tabular}{lllll}
\hline $\begin{array}{l}\text { Sections } \\
\text { (Approx.) }\end{array}$ & $\begin{array}{l}\text { T. } \\
\text { N. }\end{array}$ & $\begin{array}{l}\text { E. } \\
\text { ( }\end{array}$ & $\begin{array}{l}\text { Quadrangle name } \\
\text { ( } 7 \frac{1}{2} \text { or } 15 \text { minute) }\end{array}$ & Other district names \\
\hline$W^{\frac{1}{2}}$ & 44 & 52 & Bull Run & Centennial, White Rock \\
NW $\frac{3}{4}$ & 43 & 52 & Bull Run & Bull Run, Centennial \\
\hline
\end{tabular}

The district covers the west slope of the Bull Run (Centennial) Mountains north of Bull Run reservoir. Its east boundary is approximated by a north-south line through the summit of Porter Peak. Site of the early town of White Rock is in the northwest corner of the district, and Edgemont is near the west center. Land office records are listed under "Centennial (Bull Run) district."

Production through 1949 was reported in Granger and others (1957, p. 53). Since 1949, the Echo Canyon, Edgemont, Burns, and Burns tungsten mines' were operated on a small scale (table 18). No production was reported for the years 1965-69.

Geologic setting and ore deposits

Prospect Mountain Quartzite more.than 4,200 ft thick in the southern part of the district is overlain to the north by Cambrian through postDevonian slates, phyllites, and limestones more than 18,000 ft thick, which crop out along the north limb of the Bull Run Basin anticline. These overlying rocks are intruded by the White Rock diorite stock about 6,000 ft across and to its east by five smaller stocks most of which are in the adjoining Aura district. The intrușives are estimated (Decker, 1962 , p. 42) to be Cretaceous in age. Along their contacts the limestones are metamorphosed to tactite, the shales to hornfels.

The sedimentary rocks and the stocks are cut by steep normal faults of a few feet to perhaps 2,000 ft displacement that strike north to northeast. Some of these faults are premineral in age, others postmineral. A steep normal Basin-Range fault, the Owyhee fault of Miocene or later age, borders the west edge of the Bull Run Mountains.

The ore bodies are gold-bearing quartz veins along north- and northeast-trending faults in Prospect Mountain Quartzite, zinc-bearing veins in the White Rock stock, and tungsten-bearing tactite in limestone near one of the smaller stocks. Radioactive anomalies of two or three times background were prospected along the southwest border of the White Rock stock, and along a fault between Prospect Mountain Quartzite and Cambrian limestone near the border, but no radioactive minerals were identified. 


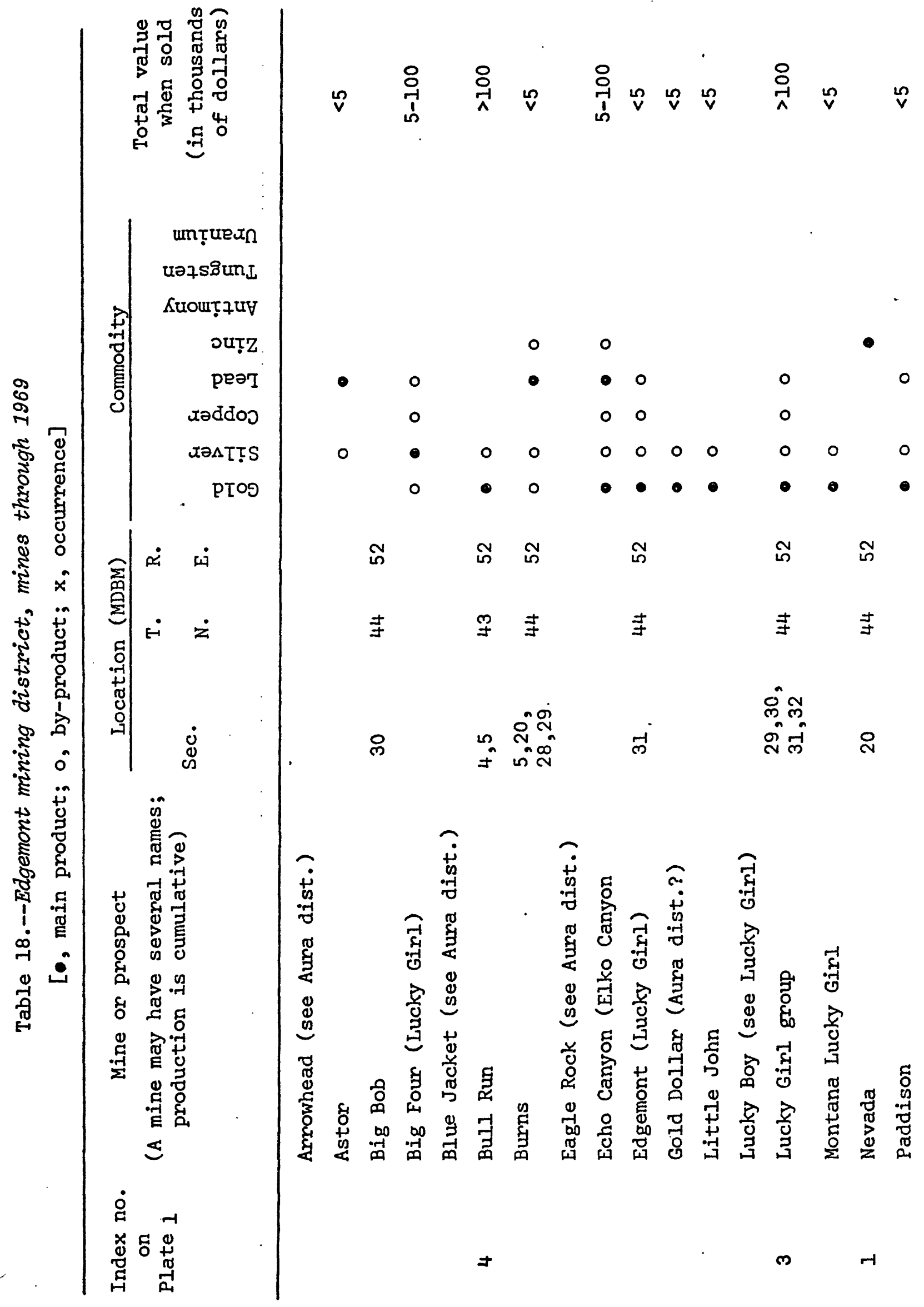




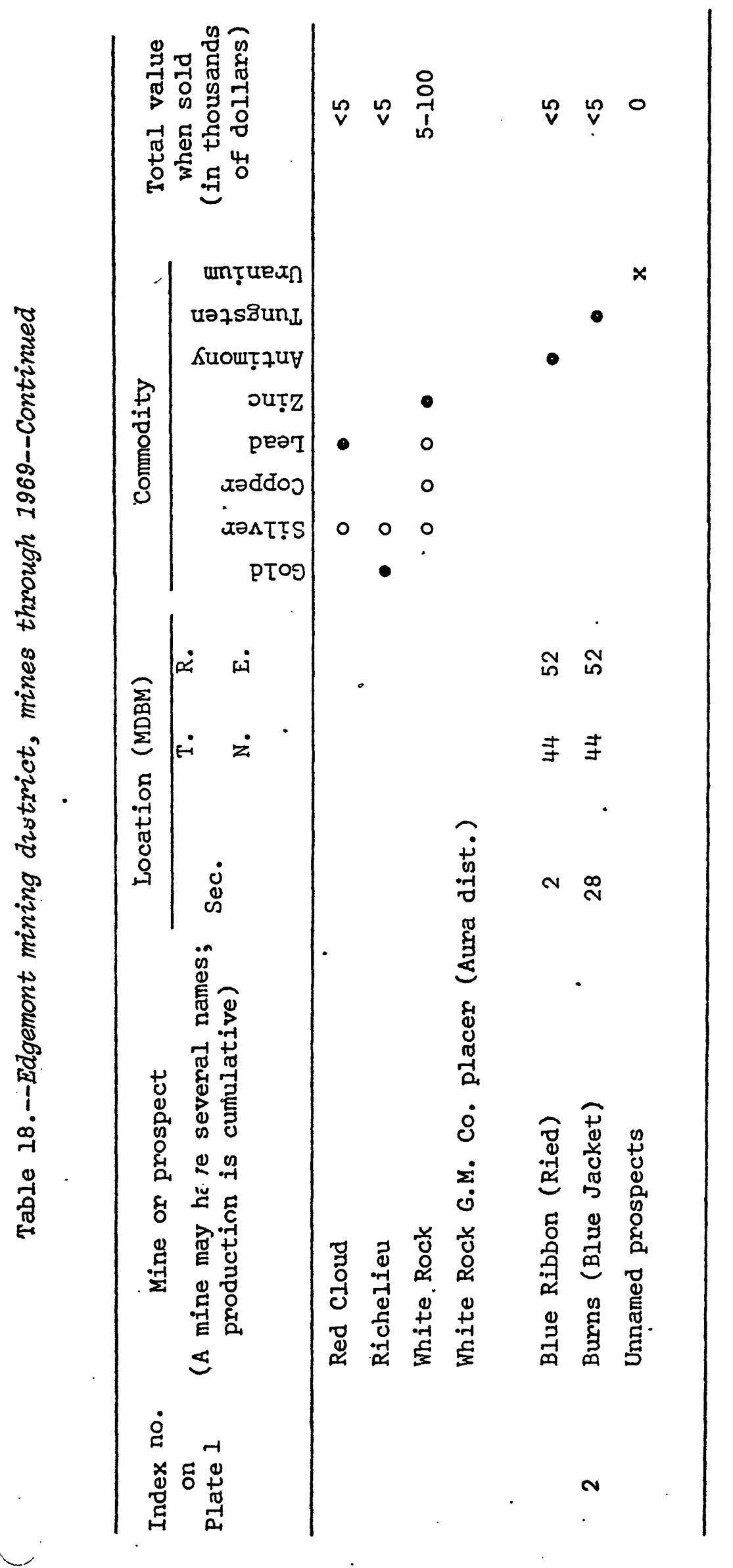


The largest ore bodies mined were in quartz veins in the quartzite. The Bull Run, Lucky Boy, Lucky Girl, and Big Bob quartz veins were developed by about 6 miles of workings for as much as $3,200 \mathrm{ft}$ along the strike and $900 \mathrm{ft}$ down the dip; they ranged from a few inches to about $7 \mathrm{ft}$ in thickness. The veins are offset in several places as much as $60 \mathrm{ft}$ by postmineral normal faults (Emmons, 1910, p. 75-80).

Gold, the main ore mineral, and silver occur with pyrite, galena, arsenopyrite, and rarely chalcopyrite or their oxidation products in ribboned quartz. Near the veins the quartzite wall rock contains a little sericite. Grade of the ores averaged about 0.25 oz gold per ton, but one 7-ton shipment contained $74 \mathrm{oz}$.

Elk Mountain district ${ }^{*}$

Location and history

\begin{tabular}{|c|c|c|c|}
\hline $\begin{array}{l}\text { Sections } \\
\text { (Approx.) }\end{array}$ & $\begin{array}{l}\text { T. R. } \\
\text { N. E. }\end{array}$ & $\begin{array}{l}\text { Quadrangle name } \\
\text { ( } 7 \frac{1}{2} \text { or } 15 \text { minute) }\end{array}$ & Remarks \\
\hline$S^{\frac{1}{2}}$ & 4761 & Elk Mountain & \\
\hline $\mathrm{N}^{\frac{1}{2}}$ & 4661 & Elk Mountain & Southwest end of Elk Mountains \\
\hline
\end{tabular}

According to Schrader (1912, p. 154), copper minerals were found in the district at least as early as 1890. At the time of his visit in 1910, all the prospects listed in table 19 were known. Since then, little work has been done, and no production is recorded for the district through 1969.

\section{Geologic setting and ore deposits}

Quartzites overlain(?) by shales and limestones all of Cambrian age have been domed and intruded by a stock of granodiorite of Cretaceous(?) age about 2 miles in diameter. Near their contacts with the granodiorite the limestones are locally metamorphosed to tactite. The sedimentary rocks, the tactite, and the granodiorite are cut by mineralized veins and veinlets of quartz or calcite. This entire assemblage is partly covered by older and younger rhyolite flows and tuffs(?) of Tertiary age all of which has been subsequently cut by faults that strike northeast and offset by later faults that strike northwest. Most of the stock is exposed by erosion.

The ore bodies are veins along faults in the granodiorite, limestone, and quartzite, and contact metamorphic deposits in tactite. Quartz veins as much as $6 \mathrm{ft}$ wide contain pyrite, irọn oxide, oxide copper minerals, native copper, stibnite, argentite, and gold. Assays of 3 percent copper and 0.35 oz gold per ton have been reported.

The langest tactite body is 1,500 ft long and at least $50 \mathrm{ft}$ wide. Contact metamorphic mineral deposits as much as $14 \frac{1}{2} \mathrm{ft}$ wide contain malachite, azurite, chrysocolla, chalcopyrite, bornite, and a little molybdenite, scheelite, gold, and silver in a gangue of silicated or garnetized limestone, or in quartz veinlets in the tactite. Assays as high as 16 percent copper 


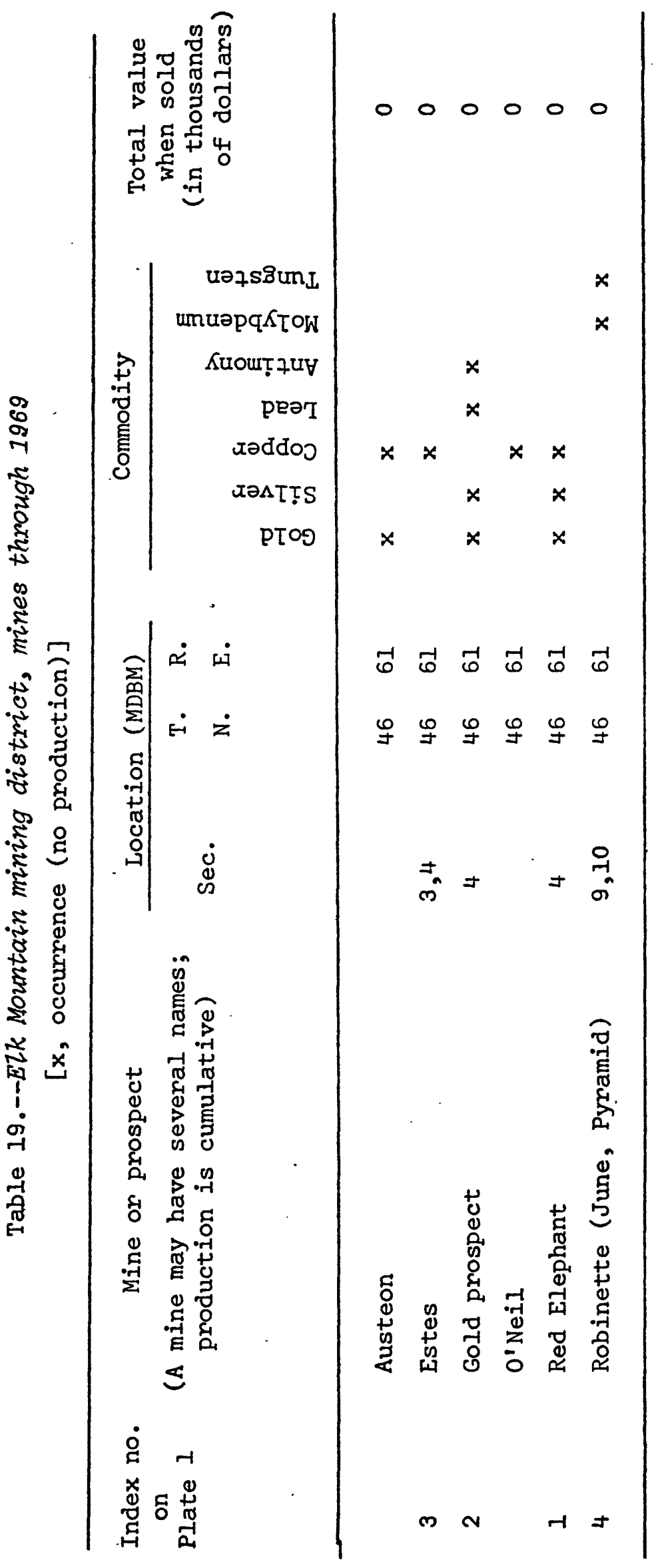


were reported (Schrader, 1912, p. 156). At the Robinette prospect (pl. 1), particles of scheelite and molybdenite are scattered throughout the tactite, but only small portions contain as much as 0.25 percent $\mathrm{WO}_{3}$ and 0.2 percent $\mathrm{MoS}_{2}$ (D. M. Lemmon, written commun., 1948).

\section{Elko district}

Location and history

\begin{tabular}{|c|c|c|c|c|}
\hline $\begin{array}{l}\text { Sections } \\
\text { (Approx.) }\end{array}$ & $\begin{array}{l}\text { T. } \\
\text { N. }\end{array}$ & $\begin{array}{l}\text { R. } \\
\text { E. }\end{array}$ & $\begin{array}{l}\text { Quadrangle name } \\
\text { ( } 7 \frac{1}{2} \text { or } 15 \text { minute) }\end{array}$ & Remarks \\
\hline All & 34 & 54 & Hunter, Elko West & Phosphorite, oil shale \\
\hline AlI & 34 & 55 & Elko West, Elko East & Oil shale, stone \\
\hline$W^{\frac{1}{2}}$ & 34 & 56 & Elko East & Oil shale \\
\hline
\end{tabular}

The Elko district includes the south ends of the Adobe Range and of the Elko Hills (Elko Mountains, pl. 1).

Oil shale and interbedded lignite were discovered in the Elko Hills about 1870 and were explored by the Central Pacific Railroad Co., Southern Pacific $C_{0}$, and others until about 1920. The oil shales were developed through inclined shafts and several thousand feet of drifts. Several types of distillation plants were tried during the years 1914 to 1920. Shale oil valued at $\$ 1,920$ was produced during 1917 and 1918, and about 15,000 gal was produced in an experimental plant in 1919 (Bulwulda, 1923, p. 101). Lignite was prospected in numerous pits and shafts in hope of obtaining good fuel for locomotive and domestic use but without success.

Conglomerate was quarried in the Elko Hills $2 \frac{1}{2}$ miles south of Elko from the Diamond Peak Formation for use as building stone prior to 1923 (Winchester, 1923, p. 93).

A copper prospect about 5 miles north of Elko was explored by trenching during 1957.

Phosphorite deposits were noted (Ketner, 1970, p. B108) in the southern Adobe Range.

\section{Geologic setting and ore deposits}

The oldest rock formation exposed in the Elko district is the Diamond Peak Formation comprising sandstone, conglomerate, and shale of Mississippian age, which crops out in the Elko Hills and in the southern Adobe Range.

In the Elko Hills the Diamond Peak Formation is overlain unconformably by the predominantly shaly Elko Formation of Eocene-Oligocene age which covers an area of about 30 square miles southeast of the Humboldt River. Small patches of rhyolite tuff and andesite tuff of the Indian Wells Formation of Oligocene age overlie the shales (Smith and Ketner, 1975). Northwest of the river in the vicinity of Elko the shales crop out in a few places, 
but part of the formation is covered by rhyolite. The shale beds range in thickness from a few feet to a few tens of feet and are interbedded with sandstone strata as much as $30 \mathrm{ft}$ thick, conglomerates up to $25 \mathrm{ft}$ thick, numerous limestone beds less than $8 \mathrm{ft}$, rhyolite tuffs and sills(?) generally less than $2 \mathrm{ft}$, and several lignite beds a few inches thick.

The Elko Formation south of the Humboldt River is tilted gently ts steeply eastward, averaging about $30^{\circ}$, and is cut by two sets of normal faults, one that strikes about north and another that strikes northeas $\tau$. Displacements along most of the faults could not be determined, but the shale beds are offset several hundred feet in some places.

Oil shale occurs in numerous beds throughout the Elko Formation. A bed in the upper part of the formation (Bumer Basin) is 6-10 ft thick but of low oil content ( $13 \mathrm{gal} / \mathrm{ton})$. The best occurrences are in the lower part of the formation where five stratigraphic zones a few feet to about 60 ft thick each contain several beds of oil shale. These zones, labeled (Btwalda, 1923, p1. 14) from oldest to youngest A through F, strike northward and dip about $30^{\circ}$ eastward in an area about 2 miles square. The greatest thickness of good oil shale in a single bed is a little more than $6 \mathrm{ft}$. Two beds of that thickness were mined, one in zone $A$ at the Catlin incline and the other in zone $C$ at the Norton incline. Other beds of rich oil shale are from 1 to $3 \mathrm{ft}$ thick and are separated by barren shale too thick to warrant mining two or more of them together.

Oil content of the shale beds is as high as 86.8 gallons or more per short ton, but shale yielding over 70 gallons per ton commonly occurs in beds less than a foot thick. The shale that was mined contained about 50 to 70 gallons per ton. The ultimate reserves of the region were estimated (Buwalda, 1923, p. 97) to be about 7,219,000 tons of shale that will yield more than 15 gallons per ton of paraffin-base oil having a specific gravity of about $28^{\circ}-36^{\circ}$ Baumé.

Lignite beds not more than a few inches thick occur at several horizons in the Elko Formation. The lignite is light brown and has the appearance of slightly compressed plant remains: It is markedly laminated and can be crushed in the hands.

In the southern Adobe Range the Diamond Peak Formation is overlain by limestone, sandy Iimestone, and conglomerate about 1,200 ft thick of Pennsylvanian-Permian age which in tum is overlain by siltstone, limestone, chert, shale, and conglomerate of Permian age. Nearly all beds in the upper half of the Permian sequence contain phosphorite, which resembles that of the Phosphoria Formation. The richest beds do not crop out but are indicated by loose pieces scattered on the surface. Selected samples contained as much as 13 percent $\mathrm{P}_{2} \mathrm{O}_{5}$ (Ketner, 1970). The general geology of phosphorite deposits is described under Pequop phosphate area.

The only known Geothermal Resource Area. (KGRA) in Elko County as of October 1974 is Elko Hot Springs. An area of about 8,960 acres includes secs. 14-17, 20-23, 26-29, 33, and 34, T. 34 N., R. 55 E., and is so classified by the U.S. Geological Survey in accordance with the Geothermal Steam Act of 1970. Nine other areas in the county are classified as having prospective value for geothermal resources (fig. 3 ). 


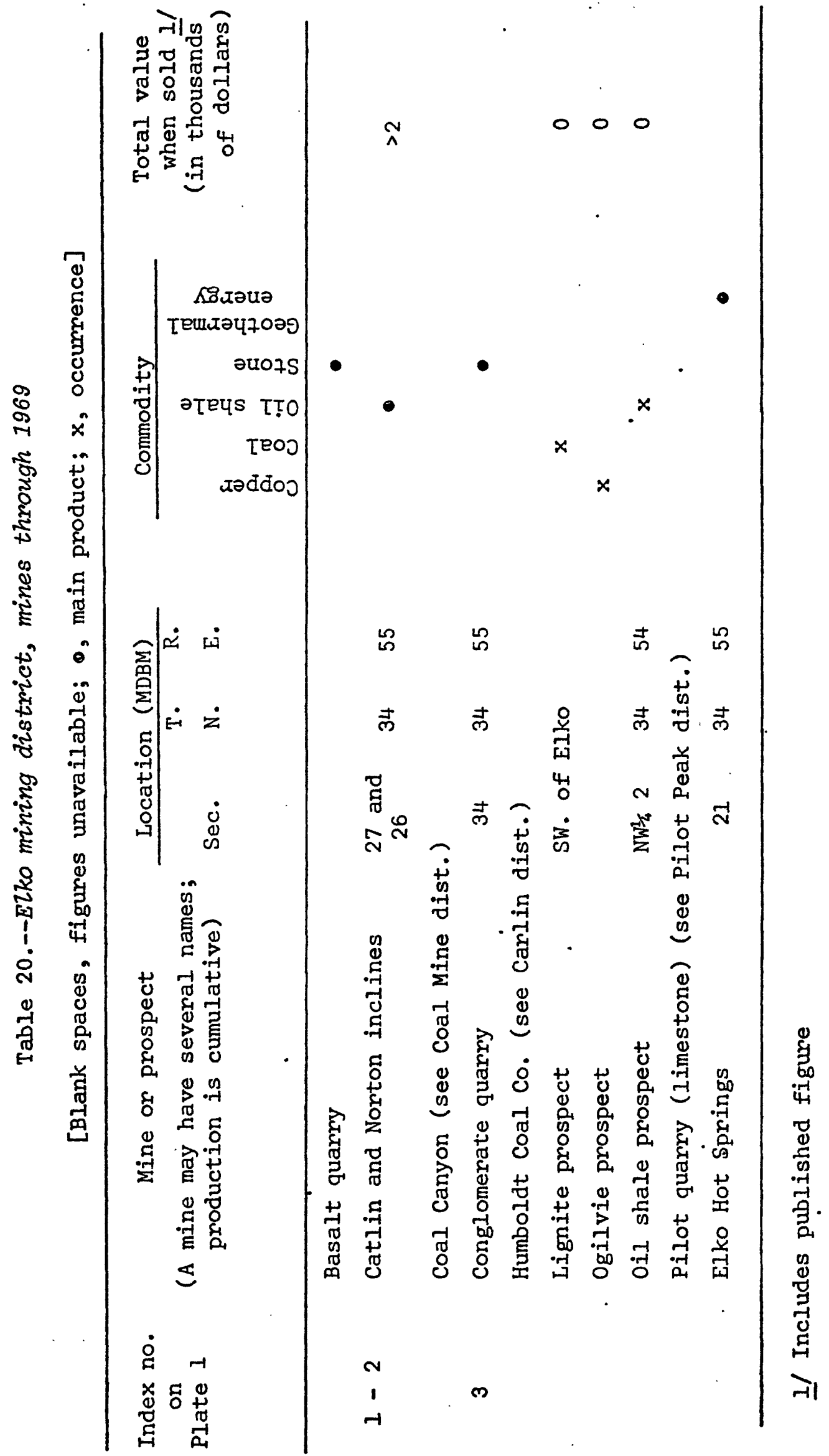


Elko Hot Springs has been used for bathing. Surface temperatures range from $150^{\circ}$ to $192^{\circ} \mathrm{F}\left(66^{\circ}-89^{\circ} \mathrm{C}\right)$. Subsurface temperatures can be determined only by drilling, but estimates can be made from the chemical composition of the water. Estimates by four different methods (table 3 ) range from $113^{\circ}$ to $380^{\circ} \mathrm{C}$ (Hose and Taylor, 1974).

Ferber district

Location and history

\begin{tabular}{llll}
\hline $\begin{array}{l}\text { Sections } \\
\text { (Approx.) }\end{array}$ & $\begin{array}{l}\text { T. } \\
\text { N. }\end{array}$ & $\begin{array}{l}\text { R. } \\
\text { E. }\end{array}$ & Quadrangle name \\
\hline $34-36$ & 28 & 69 & Elko $2^{\circ}$ \\
$31-34$ & 28 & 70 & Elko $2^{\circ}$ \\
$N E \frac{1}{4}$ & 27 & 69 & Elko $2^{\circ}$ \\
$N \frac{3}{2}$ & 27 & 70 & Elko $2^{\circ}$ \\
\hline
\end{tabular}

The Ferber district covers parts of Ferber and Whitehorse flats and extends eastward into Utah. The mining properties are on both sides of a low pass.

Copper-lead deposits were discovered in the Big Chief quartz vein by the Ferber brothers about 1880, and relocated by others about 1890. Thereafter less than 100 carloads of ore was shipped before 1914 (Hill, 1916, p. 99). Production was recorded for the years 1910-17, 1940-42, 1947, 1950, and 1957. Total recorded production through 1969 is 1,498 tons (table 5), most of it from the Martha Washington claims. The possibility of a porphyry copper deposit is suggest"ed by recent analyses of jasperoid samples which reveal anomalously high values for silver, arsenic, bismuth, copper, lead, $t$ in, and zinc similar to geochemical anomalies in the Bingham and Robinson (Ely) districts (T. G. Lovering, written commun., 1972).

Geologic setting and ore deposits

Limestones of Pennsylvania-Permian age are tilted generally westward and intruded by a stock about a mile long from east to west and a quarter of a mile wide of quartz monzonite that is locally porphyritic; and by gabbro dikes. The limestones are domed around the stock and recrystallized or metamorphosed to skarn or tactite near and parallel with the contact.

The sedimentary rocks and the intrusives are cut by steep faults most of which strike either northward and dip west or eastward and dip south, but a few trend northeast or northwest.

The ore bodies are lodes along the steep faults. Most of them are in the contact metamorphic rocks, but one quartz vein, the Big Chief, is along a nearly vertical fault that strikes east in the quartz monzonite about $100 \mathrm{ft}$ south of its north edge. The ore bodies at the Regent mine are along a shear zone which strikes N. $62^{\circ}$ W. and dips $70^{\circ} \mathrm{SW}$. in gabbro. 


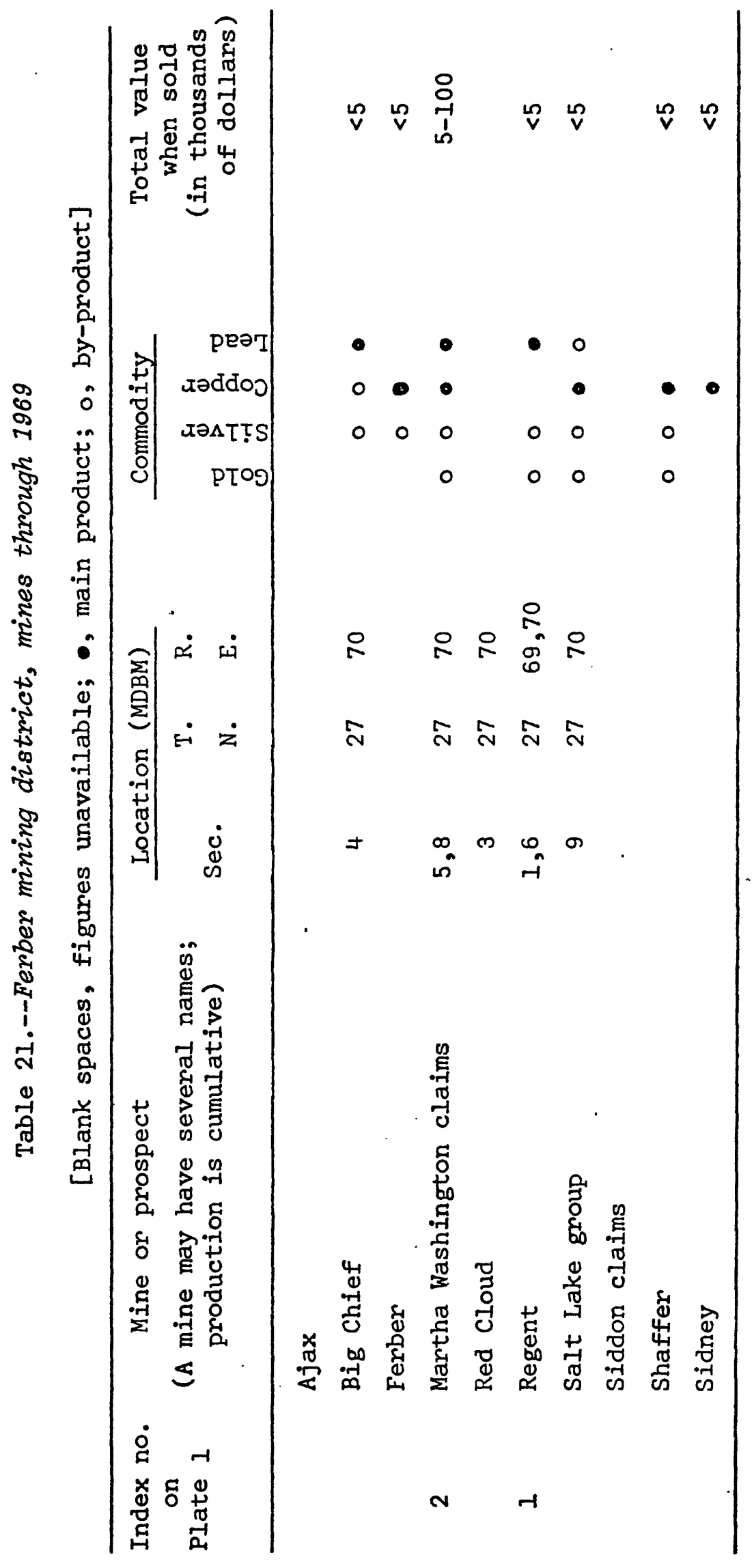


The ore shoots in the metamorphic rocks are as much as $10 \mathrm{ft}$ wide but are lenslike and rather short. They have been mined to depths of $150 \mathrm{ft}$ or more. The Big Chief vein is 2-8 ft wide, and the deepest shaft is about $75 \mathrm{ft}$ deep; the Regent shear zone is $20 \mathrm{ft}$ wide and was mined to the 300 -foot level. These depths refer to development in 1916; the extent of mining in the 1940's and 1950's is not known.

The ore minerals are mainly copper and lead carbonates containing a little silver and very little gold. Chrysocolla and copper pitch are common at the surface, chalcocite and native copper at depths of about $40 \mathrm{ft}$, and a little residual chalcopyrite, bomite, and galena at greater depths. Plumbojarosite was also reported ( $\mathrm{Hill}, 1916$, p. 102). Lime silicate minerals, quartz, and iron oxides are the main gangue minerals.

Grade of the ore from the Martha Washington mine, which was the most productive (table 2l), was said to average 12 percent copper in the early days, but the total recorded production averaged about 16 percent lead, 6 percent copper, and $14 \mathrm{oz}$ silver per ton.

Ferguson Spring district

Location and history

\begin{tabular}{|c|c|c|c|c|}
\hline $\begin{array}{l}\text { Sections } \\
\text { (Approx.) }\end{array}$ & $\begin{array}{l}\text { T. } \\
\text { N. }\end{array}$ & $\begin{array}{l}\text { R. } \\
\text { E. }\end{array}$ & $\begin{array}{l}\text { Quadrangle } \\
\text { ( } 7 \frac{1}{2} \text { or } 15 \text { minute) }\end{array}$ & Other district names \\
\hline All & 30 & 69 & Ferguson Spring & Alleghany \\
\hline$N-1 / 6$ & 29 & 69 & Ferguson Spring & Alleghany \\
\hline
\end{tabular}

The district.covers Ferguson Mountain, altitude 7,695 ft, an isolated peak east of the Goshute Mountains (Toano Range) and part of Ferguson Flat south of the peak.

According to Hill (1916, p. 97), the copper-silver deposits were said to have been known in the late 1880's. Claims staked in 1910 and 1912 were recorded under the Allegheny 1 district; land office patents are recorded under Alleghany district.

Production was recorded for the years 1935, 1937, 1939, 1949, and 1953, a small part of which may have been credited to the Pilot. Peak district.

\section{Geologic setting and ore deposits}

Limestone and subordinate interbedded cherty limestone, shale, and quartzite strata of the eastem assemblage ranging in age from Devonian to Triassic are folded or tilted and displaced by many steep faults that strike either northward or eastward, and by at least one low-angle fault. No intrusive rocks are shown on geologic maps, but Heyl and Bozion (in U.S. Geol. Survey, 1972) reported two small stocks of quartz monzonite northwest of

1/Named for George Washington Mardis, an early Indian scout and prospector called "Old Allegheny." 


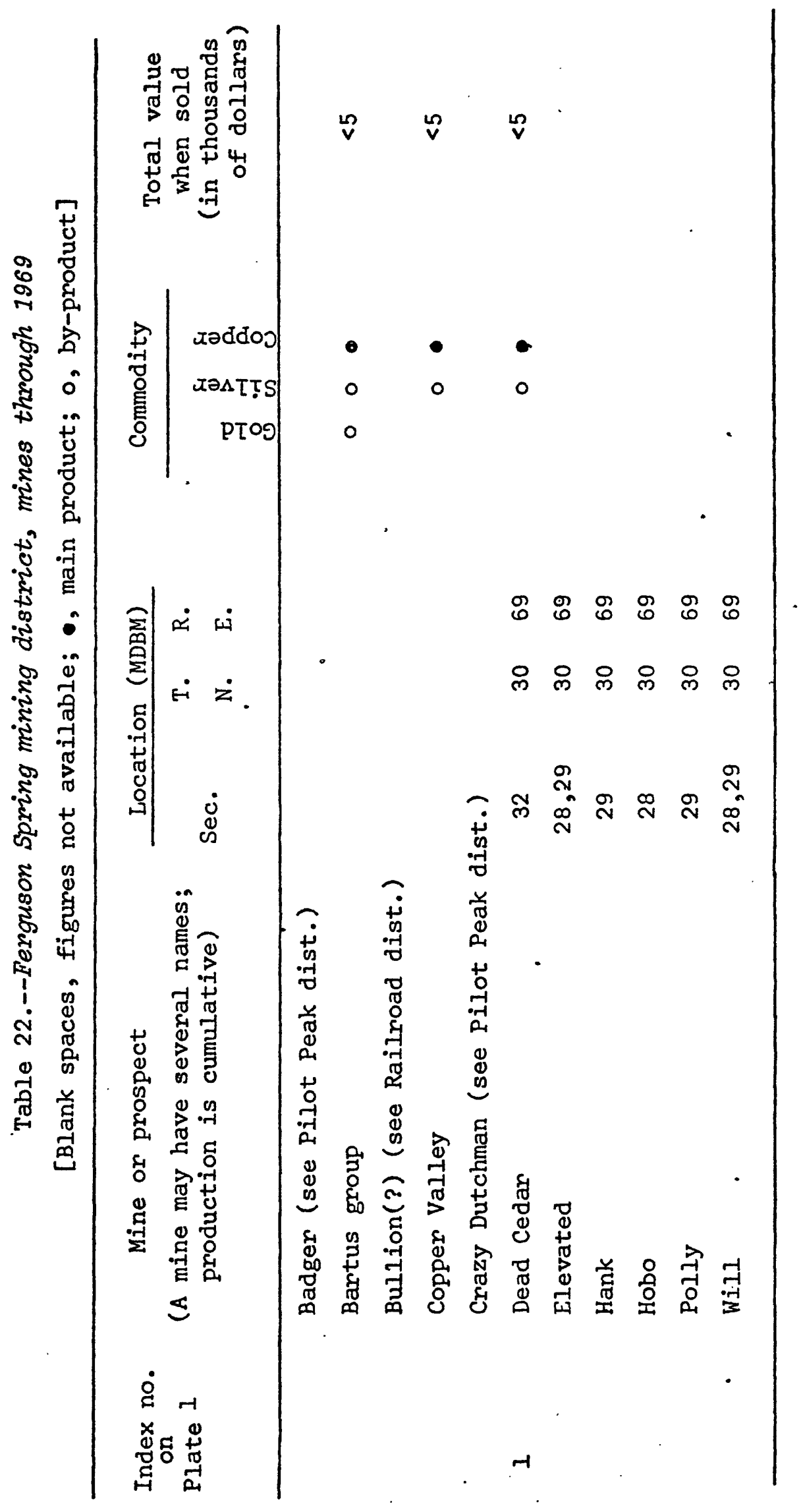


Ferguson. Zones of hydrothermally altered limestone, shale, and sandstone surround the stocks. Volcanic rock of Tertiary age covers some of the limestones on the east side of the district.

The mineralized bodies replace some of the limestone beds along and near two or more of the east-striking faults. The largest gossan is about $300 \mathrm{ft}$ long and $30 \mathrm{ft}$ wide; the deepest workings are about $50 \mathrm{ft}$ below the outcrop. All of the ore mined was oxidized. Copper carbonates with a litțle silver occur in a gangue of limonite, barite, and quartz. Average grade of the ore shipped was about 6 percent copper and $1 \mathrm{oz}$ of silver per ton.

Gilbert Canyon area

Location and history

\begin{tabular}{|c|c|c|c|c|}
\hline $\begin{array}{l}\text { Sections } \\
\text { (Approx.) }\end{array}$ & $\begin{array}{l}\text { T. } \\
\text { N. }\end{array}$ & $\begin{array}{l}\text { R. } \\
\text { E. }\end{array}$ & $\begin{array}{l}\text { Quadrangle name } \\
\text { ( } 7 \frac{1}{2} \text { or } 15 \text { minute) }\end{array}$ & Remarks \\
\hline$N^{1} / 2$ & 29 & 57 & Jiggs & Pegmatite area \\
\hline
\end{tabular}

The Gilbert Canyon pegmatite area on the west slope of the Ruby Mountains east of Jiggs includes Gilbert and McCutcheon Creeks between Green Mountain, altitude 10,680 ft, and Mound Valley, altitude about 5,500 ft.

Two of several pegmatite dikes, one near each creek, were explored for beryl by small pits and trenches prior to 1942. One in Gilbert Canyon (SE $\frac{1}{4}$ sec. 9) about $18 \mathrm{ft}$ wide contains a very few scattered beryl crystals 2-3 inches across, and a little columbite-tantalite and uraninite. A finegrained pegmatite on the north side of McCutcheon Creek (center sec. 4) contains a few green beryl crystals and a little columbite-tantalite. One sample of specific gravity 6.1 indicates about 30 percent $\mathrm{Ta}_{2} \mathrm{O}_{5}$ (Olson and Hinrichs, 1960, p. 171). No production has been reported from the area through 1969.

The area covers the north end of the Harrison Pass stock in the westcentral part of the intrusive complex described under valley view district.

Gold Basin district

Location and history

\begin{tabular}{|c|c|c|c|c|}
\hline $\begin{array}{l}\text { Sections } \\
\text { (Approx.) }\end{array}$ & $\begin{array}{l}\text { T. } \\
\text { N. }\end{array}$ & $\begin{array}{l}\text { R. } \\
\text { E. }\end{array}$ & $\begin{array}{l}\text { Quadrangle name } \\
\text { ( } 7 \frac{1}{2} \text { or } 15 \text { minute) }\end{array}$ & Other district names \\
\hline$S \frac{1}{2}$ & 47 & 56 & Rowland & Rowland \\
\hline $\mathrm{SW}^{3} \frac{1}{4}$ & 47 & 57 & Rowland & - \\
\hline
\end{tabular}

The Gold Basin district includes the Bruneau River canyon north of Mink Ranch to the confluence of McDonald Creek and also the mountainous area east of the canyon to Bearpaw Mountain. 


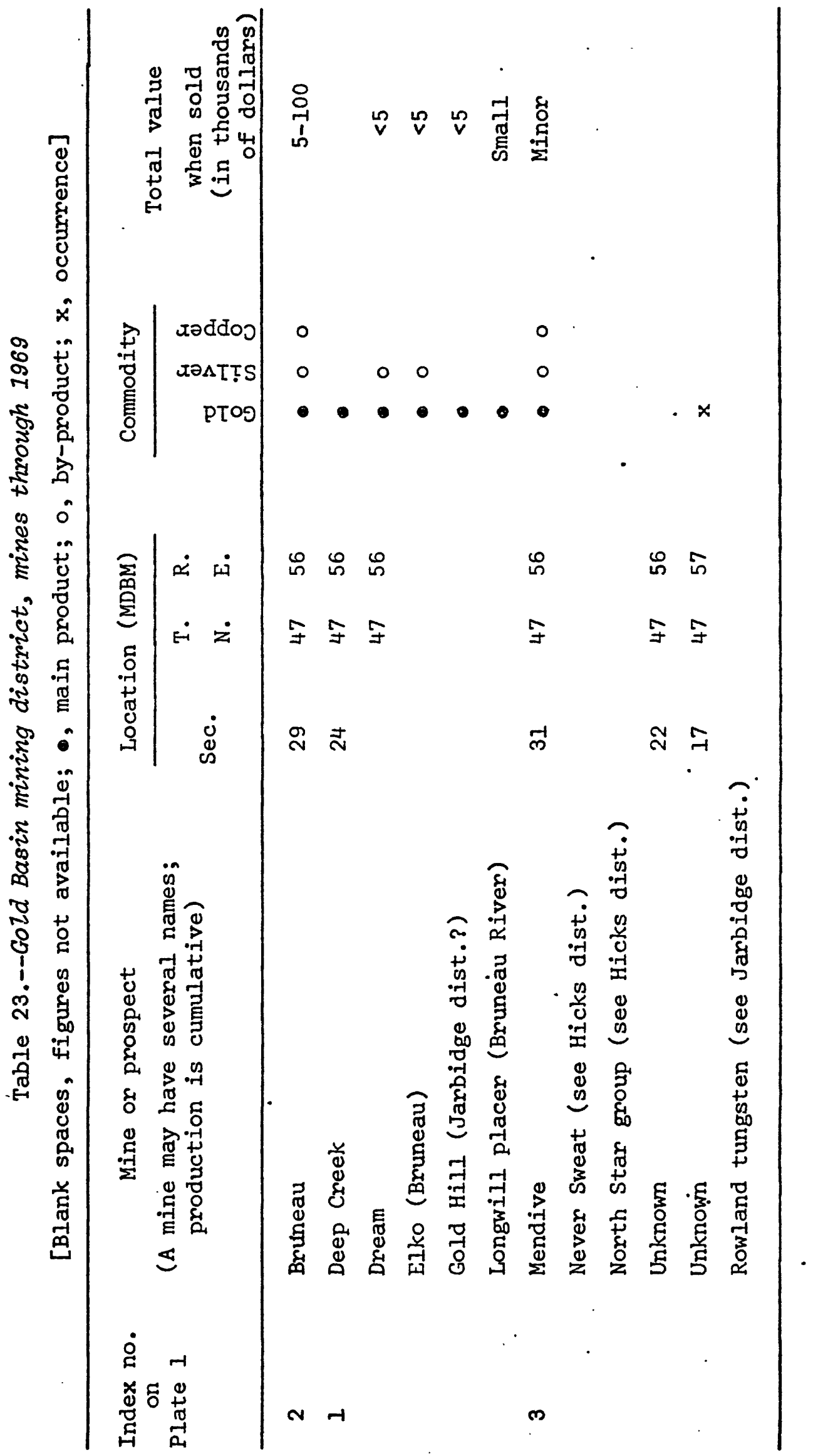


Placer gold was discovered along the Bruneau River in 1869, but no. production was recorded during the $1800^{\prime} \mathrm{s}$. Vanderburg (1936, p. 72) reported that "small-scale placer operations have been carried on intermittently for a number of years" prior to and during 1931, and that the gravel yielded less than $\$ 1$ per cubic yard.

Lode deposits were mined from 1930 through 1941 (table 23); part of the production may have been credited to the Island Mountain district. At the Bruneau (Elko) mine, two tunnels were driven along fissure veins, a mill was built, and a small amount of gold-silver-copper ore was produced from 1930 through 1940. No production is reported from the district since 1941.

Geologic setting and ore deposits

Paleozoic limestones, schist, argillites, and phyllites about a mile thick are exposed along the canyon walls of the Bruneau River and Taylor Creek and on the slopes of Bearpaw Mountain. South of Bearpaw Mountain they are intruded by the Deep Creek quartz monzonite stock about 3 miles wide north to south and 7 miles long of Cretaceous age. In the rest of the district they are covered by Bieroth andesite flows or later Idavada rhyolite tuffs and flows of Tertiary age (Bushnell, "1967, pl. 1).

The Paleozoic rocks are tilted to nearly vertical and cut by numerous - faults that strike northwest, northeast, or east. Quartz veins along some of the faults in limestone near the north side of the stock yielded a little gold (Bushnell, 1967, p. 34). The Bruneau and Mendive quartz veins near Rowland are nearly 3 miles west of the stock and contained, in addition to gold, a little silver and copper. One of the veins was 18 inches wide. Average grade of all reported lode production was $0.30 \mathrm{oz}$ gold and $0.68 \mathrm{oz}$ silver per ton.

Gold Circle district

Location and history

\begin{tabular}{lllll}
\hline $\begin{array}{l}\text { Sections } \\
\text { (Approx.) }\end{array}$ & $\begin{array}{l}\text { T. } \\
\text { N. }\end{array}$ & $\begin{array}{l}\text { E. } \\
\text { All }\end{array}$ & $\begin{array}{l}\text { Quadrangle name } \\
\left(7 \frac{1}{2} \text { or } 15 \text { minute }\right)\end{array}$ & Other district names \\
\hline W-1/3 & 46 & $\begin{array}{c}\text { Midas, Squaw Valley } \\
\text { Ranch }\end{array}$ & Midas, Summit \\
\hline
\end{tabular}

The Gold Circle district covers the east end of the Owyhee Bluffs between Midas and Fraziers Creeks. The Eastern Star mine may be in R. $46 \mathrm{E}$. (sec. 13) or in R. $47 \mathrm{E}$.

Lode gold was discovered in several veins during the summer of 1907 , and a gold rush occurred the same year. A town, first called Rosebud, then Gold Circle because the mines encircled it, and finally Midas because the postal department refused to name another office beginning with the word "gold," soon reached a population of 1,500 . The excitement quickly 
subsided when the ores were found to require milling, so that by the end of 1908 only about 250 persons remained. Production reached a peak in 1916 (24,000 tons at 0.9 oz per ton), ceased in 1921 when the last of six or more mills burned, revived in 1928-29 (cyanide plant), again in 1939 (29,000 tons at 0.23 oz per ton), and ceased in 1942. From 1950 through 1965, intermittent prospecting and cleanup at millsites yielded 187 tons of ore containing $242 \mathrm{oz}$ gold, 4,484 oz silver, $100 \mathrm{Ib}$ copper, and $200 \mathrm{lb}$ zinc. No further production is reported through 1969.

\section{Geologic setting and ore deposits}

Within the district only Tertiary volcanic rocks are exposed. The oldest are rhyolite flows and tuffs which are overlain conformably by andesite flows interlayered with basalt and diabase flows. The andesite is overlain conformably by postandesite rhyolite which is partly eroded and unconformably overlain by Cougar Point Welded Tuff of Pliocene age several hundred feet thick.

The volcanic rocks below the welded tuffs are cut by three sets of premineral faults. One set that strikes eastward and dips steeply south is in places intruded by dikes of rhyolite or andesite as much as $100 \mathrm{ft}$ wide and $600 \mathrm{ft}$ long but is not itself mineralized. A second set strikes N. $30^{\circ}-60^{\circ} \mathrm{W}$. and dips steeply northeast or southwest. Some faults of this set are occupied by andesite dikes, others by quartz veins. A third set is represented only by the Reco No. 2 vein (Rott, 1931, pl. 1) which strikes N. $10^{\circ} \mathrm{W}$. and dips steeply east.

A lamprophyre dike $1-3 \mathrm{ft}$ wide is intruded along one of the veins, the Missing Link, and is younger than the vein. All three sets of faults have gouge and slickensides along them resulting from postmineral movement.

Postmineral faults offset the mineralized faults a few inches to several feet in a few localities, but the largest postmineral displacements are along or parallel with the veins and are marked by slickensides and gouge. Where a postmineral fault follows a vein, the gouge contains crushed ore identifiable by panning. Where the fault diverges from or is parallel with a vein, the gouge is barren.

Hydrothermal alteration is pronounced in the mineralized areas. Rhyolite is leached and bleached to a chalky white rock containg calcite, chlorite, sericite, adularia, and streaks of limonite stain. The basic rocks are altered to serpentine, calcite, quartz, chalcecony, and kaolin.

The ore bodies are quartz veins deposited in open fissures, sheeted zones, and breccia zones along the northwest- and northeast-striking premineral faults in rhyolite or along the contact of Elko Prince rhyolite with andesite. Age of the mineralization is about $15.0 \mathrm{~m} . \mathrm{y}$. or middle Miocene (Roberts and others, 1971, p. 30). The fissure veins and sheeted zones range in width from a few inches to 3 or $4 \mathrm{ft}$, breccia veins from a few inches to $25 \mathrm{ft}$. Six main veins, Elko Prince, Gold Crown, Missing Link (Banner-St. Paul), Reco, Grant-Jackson, and Esmeralda (Gibson) have been traced by discontinuous outcrops for 2,800-5,000 ft along their strikes (Rott, 1931, pl. 1). The Elko Prince and Grant-Jackson veins terminate at their intersections with east-striking faults. 


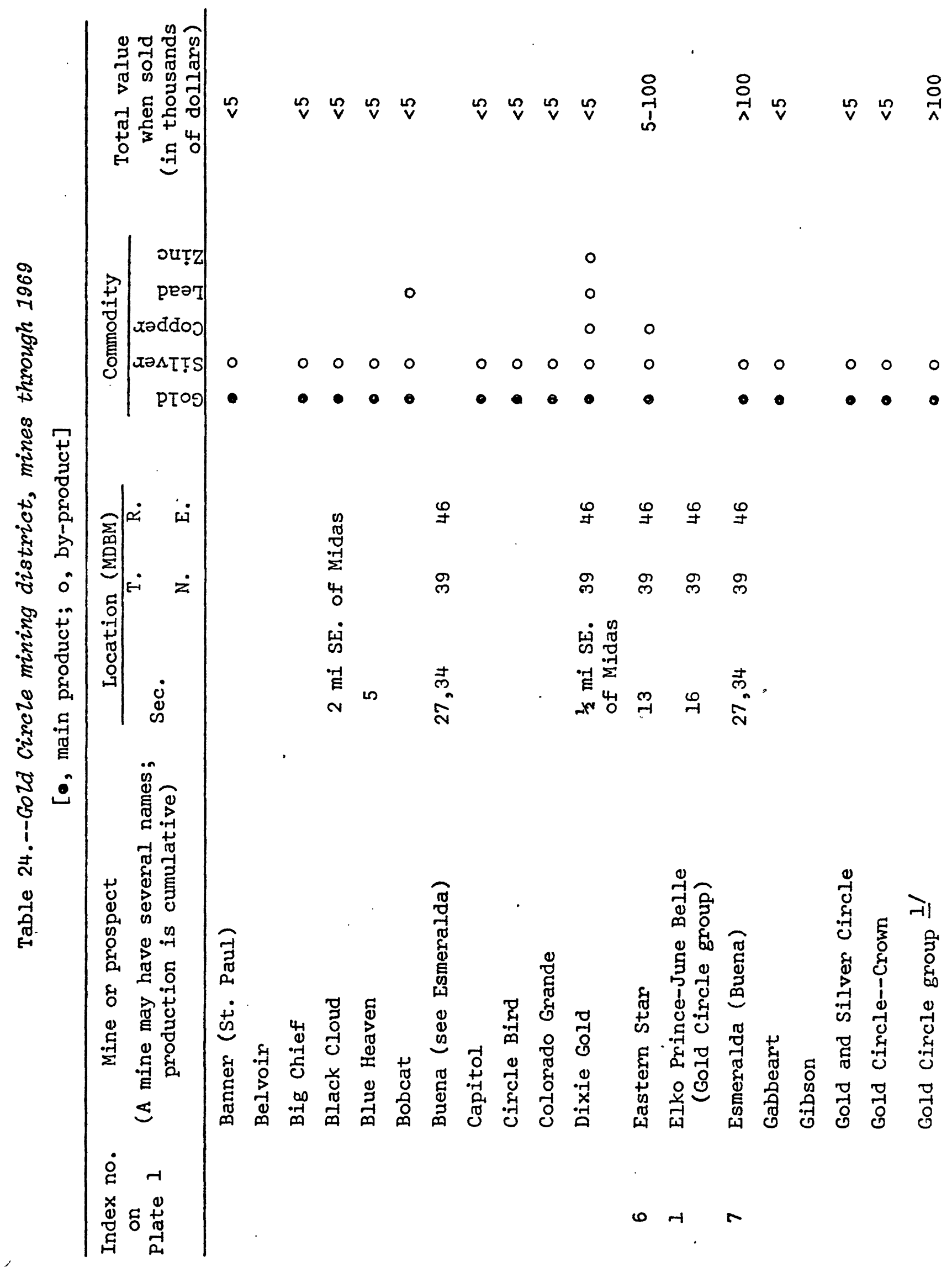




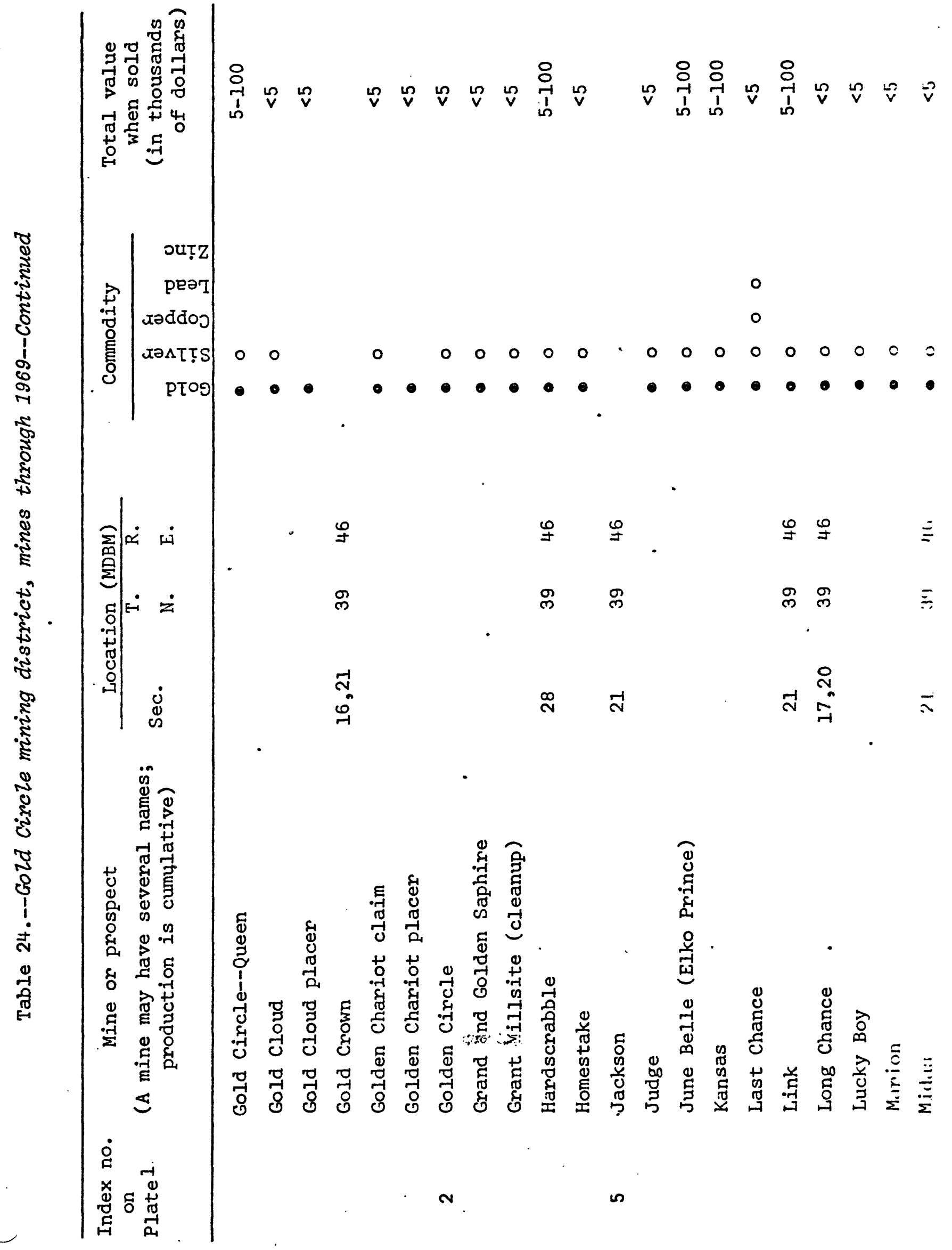




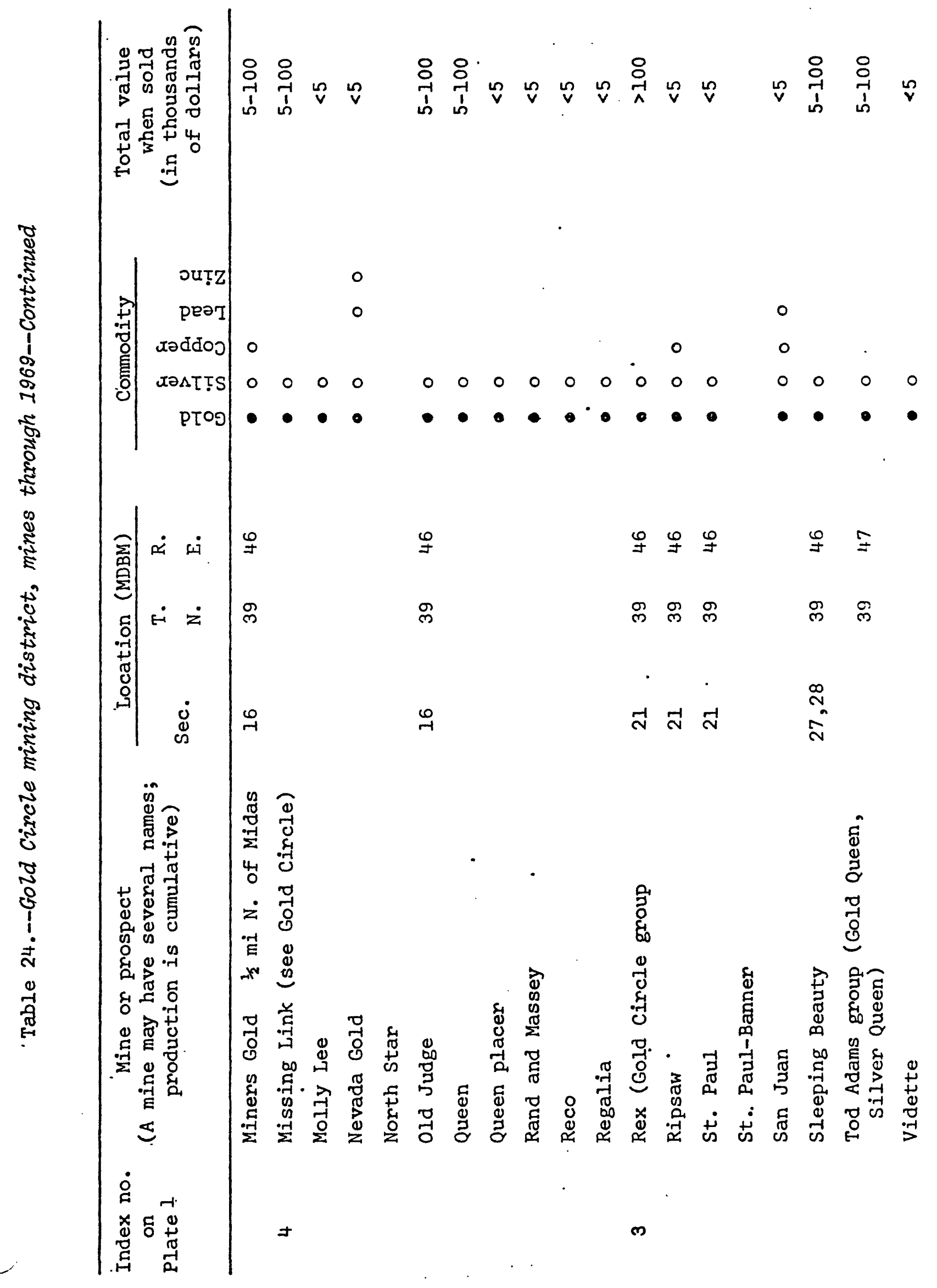




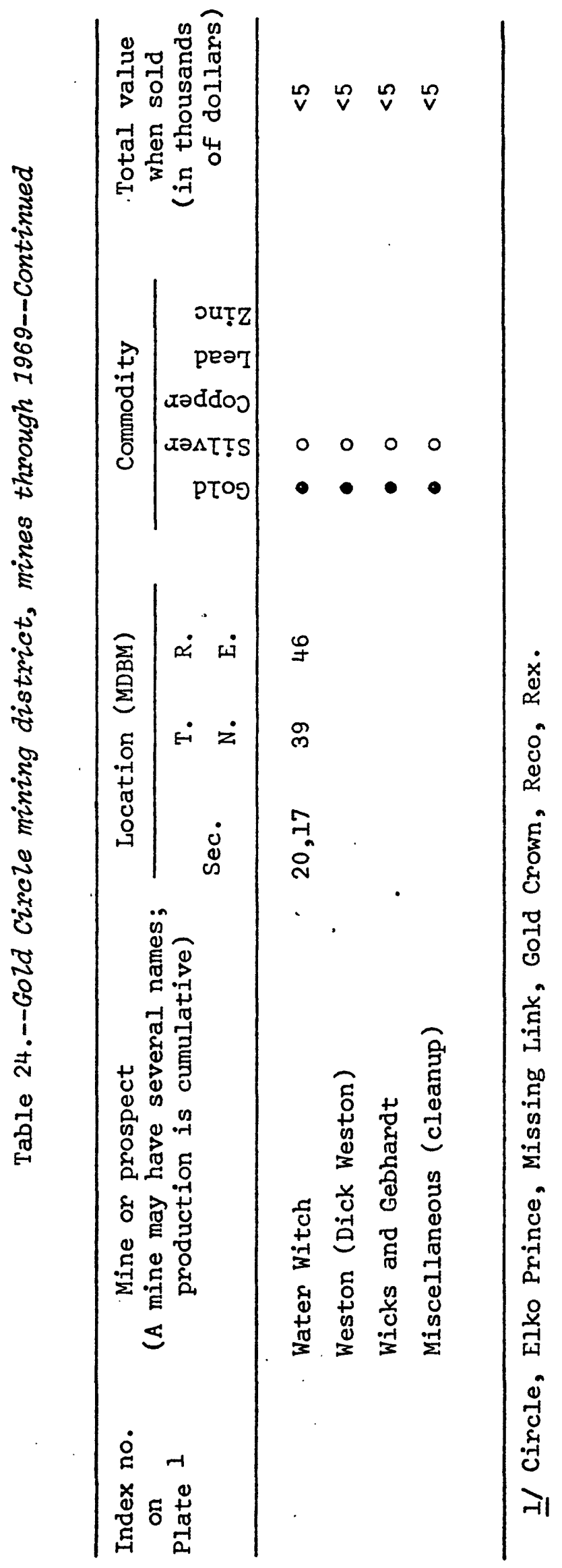


Ore shoots are localized along portions of the veins. The main ore shoot in the Elko Prince vein was 630-810 ft long, averaged 15-30 inches wide, and was mined from above the 270-foot level to below the 750-foot level. Other ore shoots in the district ranged from a high-grade seam 2 or 3 inches wide along the Gold Crown vein to low-grade mill ore as much as $25 \mathrm{ft}$ wide, also in the Gold Crown.

The ore minerals are free gold and locally stromeyerite, cerargyrite, and native silver in the upper portions of the ore shoots, and gold, tetrahedrite, proustite, argentite, sphalerite, and chalcopyrite in the deeper levels. Sulfides occur within a foot or two of the surface in some places, but partial oxidation extends to depths of 70-150 ft.

Gangue minerals are mainly quartz, chalcedony, and pyrite with small amounts of calcite, chlorite, and adularia. In the oxide zone, iron and manganese oxides are common.

Grade of the ore mined ranged from several thousand dollars a ton for the narrow seam in the Gold Crown vein to about $\$ 5$ a ton for mill ore during the later years of mining. Average grade of all production recorded through 1969 was $\$ 10.18$ a ton for 401,659 tons containing 0.317 oz gold and 4.1 oz silver per ton. The gold-silver ratio ranged from predominantly gold in the leached upper portions of the ore shoots to predominantly silver in the primary sulfides at depth and averaged about 1:13. Small amounts of lead, copper, and zinc were recovered only from shipments in later years.

Good Hope district

Location and history

\begin{tabular}{|c|c|c|c|c|}
\hline $\begin{array}{l}\text { Sections } \\
\text { (Approx.) }\end{array}$ & $\begin{array}{l}\text { T. } \\
\text { N. }\end{array}$ & $\begin{array}{l}\text { R. } \\
\text { E. }\end{array}$ & $\begin{array}{l}\text { Quadrangle name } \\
\text { ( } 7 \frac{1}{2} \text { or } 15 \text { minute) }\end{array}$ & Other district names \\
\hline 11 & 41 & 49 & Mount Blitzen & Aurora, Amazon \\
\hline
\end{tabular}

Two former districts, the Amazon and the Aurora, are now included in the Good Hope district. The Amazon district in the northeast corner of the township included the Amazon and Silver Brick mines where silver ore was discovered in 1873. The Aurora district in the west half of the township was organized in 1875, and included the Buckeye and Ohio, Snyder, and Page and Kelley mines. The area was renamed Good Hope, probably in 1878 .

The Good Hope district "is said to have produced over $\$ 100,000$ in silver" (Emmons, 1910, p. 65), most of it from the Buckeye and Ohio during 1882-84. Very little mining has been done since 1903. A shipment of silver ore was made in 1921, and several thousand pounds of antimony was produced from the Buckeye and Ohio mine in 1950 (credited to the Good Hope mine). No further production was reported from the district through 1969. 


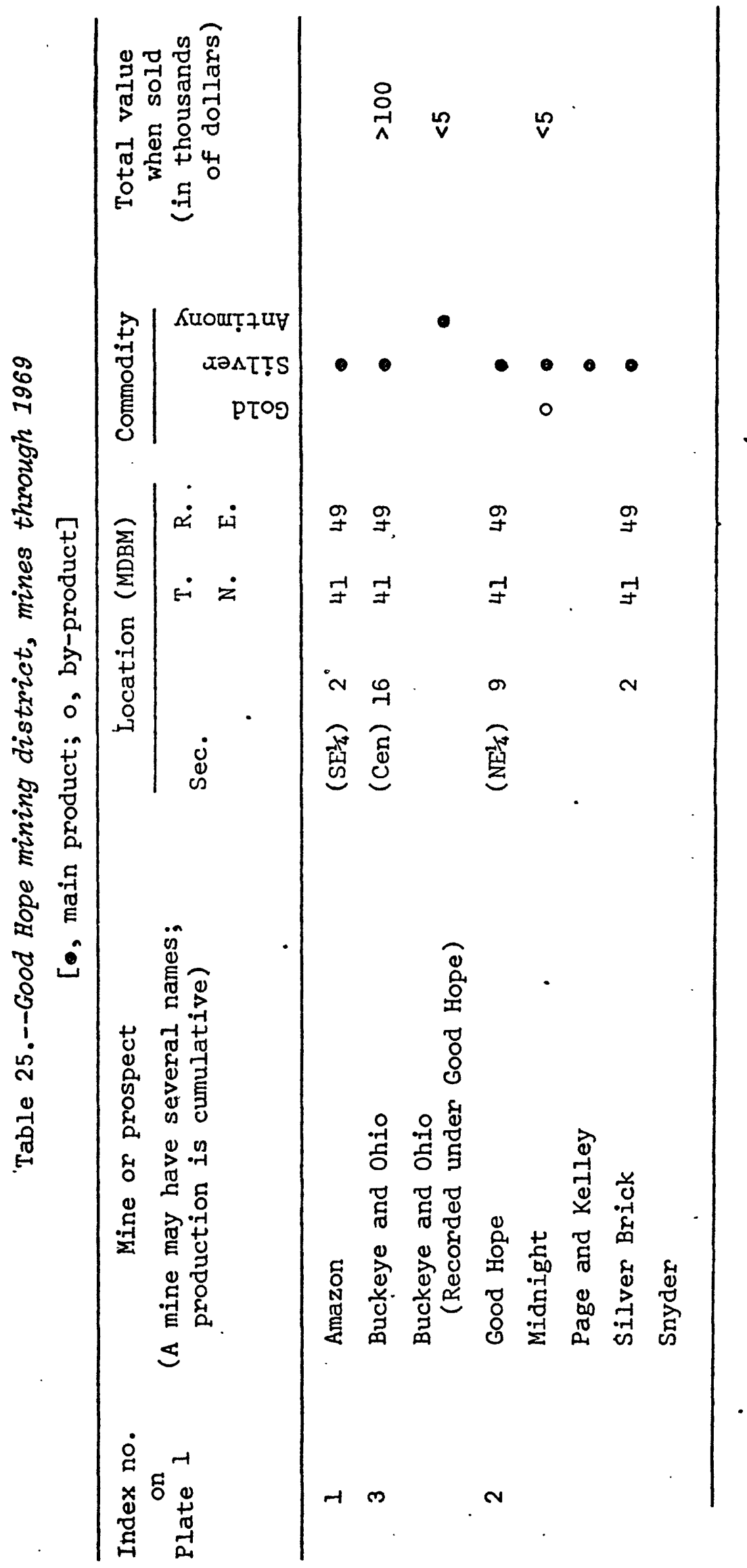


Geologic setting and ore deposits

The oldest rock unit exposed in the district is quartzite of the Valmy Formation of Ordovician age. It is overlain unconformably by rhyolitic welded tuffs and andesite flows, dikes, and sills of Eocene(?) age. These older volcanics are unconformably overlain by erosion remants of fresh-water limestone and by rhyolitic welded tuffs and flows of Miocene(?) age. The older volcanics are locally mineralized (Knox, 1970, p. 1-24).

The ore bodies are narrow quartz veins along faults that strike northward or northeastward and dip steeply in the older volcanics. The largest ore shoots mined were in the Buckeye and ohio mine where two intersecting quartz veins as much as $5 \mathrm{ft}$ wide contained pyrite, arsenopyrite, freibergite, stibnite, and dark ruby silver. A sample (Lawrence, 1963, p. 61) across 36 inches of vein material assayed 7.6 oz silver, 14.1 percent antimony, and a trace of gold. The depth mined is not known but probably did not exceed $100 \mathrm{ft}$.

Goose Creek district

Location and history

\begin{tabular}{|c|c|c|c|c|}
\hline $\begin{array}{l}\text { Sections } \\
\text { (Approx) }\end{array}$ & $\begin{array}{l}\mathrm{T} \text {. } \\
\text { N. }\end{array}$ & $\begin{array}{l}\text { R. } \\
\text { E. }\end{array}$ & $\begin{array}{l}\text { Quadrangle name } \\
\text { ( } 7 \frac{1}{2} \text { or } 15 \text { minute) }\end{array}$ & \\
\hline Al1 & 47 & 69 & Goose Creek & $=$ \\
\hline AII & 47 & 70 & Goose Creek & \\
\hline
\end{tabular}

Most of the Goose Creek district is in Idaho, but the mineralized formations extend southward in the Goose Creek drainage area into Utan and into the northeast comer of Elko County, Nev. A Goose Creek mining district mentioned by Whitehill (1875, p. 33) 25 miles north of Tecoma and 10 miles from the Utah line is evidently the Delano district.

There has been no production from the part of the district in Elko County. Lignite and building stone have been produced for local use from the part in Idaho, and bentonite has been prospected in Utah.

\section{Geologic setting and ore deposits}

Limestone, marble, quartzite, and shale of Carboniferous age and older are exposed in the mountains on the west and northeast edges of the district. They are in places overlain by a large body of rhyolite of Tertiary(?) age exposed in the mountains bordering the district on the southeast. Unconformably overlying the rhyolite and the older rocks are two formations of Miocene-Pliocene ages that are exposed throughout most of the district. They include greenish-gray shale and white volcanic ash of the Payette(?) Formation at least $900 \mathrm{ft}$ thick, overlain by volcanic ash and welded rhyolitic tuff of the Salt Lake Formation which is at least 2,300 ft thick. Both formations contain thin beds of carbonaceous 
shale and lignite, and numerous beds of sandstone and conglomerate. The formations are tilted generally eastward about $3^{\circ}$ throughout most of the district, but in Elko County the prevailing dip is westward. The strata are locally displaced a few feet to as much as $900 \mathrm{ft}$ along normal faults, most of which trend northward or northeastward (Maple and Hail, 1959, p. 217).

Lignite occurs in both the Payette and Salt Lake Formations. Two main beds have been mined, a lower bed of better quality 3-5 ft thick and an upper bed 14 inches to $9 \mathrm{ft}$ thick (Bowen, 1913, p. 257).

Building stone was quarried from the quartzite and marble beds in the older formations and from welded tuff and volcanic ash beds in the Salt Lake Formation (Maple and Hail, 1959, p. 253).

Bentonite (montmorillonite) in lenticular beds up to $20 \mathrm{ft}$ thick and several hundred yards or more long in the Payette and Salt Lake Fornations crops out in Idaho, Utah, and in Elko County (Maple and Hail, 1959, p. 253).

Uranium in concentrations of as much as 0.1 percent uranium occurs locally in lignite and carbonaceous shales in the lower part of the Salt Lake Formation (Maple and Hail, 1959, p. 217).

Vanadium with a trace of selenium occurs in black shale in the Salt Lake Formation; a single sample from Goose Creek Valley in Elko County assayed 0.2 percent vanadium (Davidson and Lakin, 1962).

Halleck district

Location and history

$\begin{array}{lllll}\text { Sections } & \text { T. } & \text { R. } & \text { Quadrangle name } & \text { Remarks }\end{array}$

\begin{tabular}{llll}
\hline 35,36 & 35 & 59 & Hawthorn placer \\
$1,2,3(?)$ & 34 & 59 & Secret Creek area
\end{tabular}

The original reference to the Halleck district is by Whitehill (1875, p. 31). It is reproduced in full as follows:

"The district is situated on the northwestern slope of the Ruby range of mountains, about six miles from Fort Halleck. Several locations have been made here by the officers and soldiers from the Fort. But little work has yet been done. The district was organized during the summer of eighteen hundred and seventy-three, and a recorder was elected. Wood is scarce, but water is abundant. Gold is found in most of the veins, which also show silver from two dollars and fifty cents to sixty dollars per ton. The railroad is eighteen miles distant, from which there is a good road to the mines. Lamoile, one of the finest agricultral valleys. in the state, is in the immediate vicinity."

The Hawthom placer is the only patented claim in the district. Production, if any, from the district has not been recorded. 
Harrison Pass district

Location and history

\begin{tabular}{lllll}
\hline $\begin{array}{l}\text { Sections } \\
\text { (Approx.) }\end{array}$ & T. & R. & $\begin{array}{l}\text { Quadrangle name } \\
\text { ( } \frac{1}{1} \frac{1}{2} \text { or } 15 \text { minute) }\end{array}$ & Other district names \\
\hline$W^{\frac{1}{2}}$ & 28 & 58 & Franklin Lake SW & Ruby Valley \\
\hline
\end{tabular}

The Harrison Pass district is on the east slope of the Ruby Mountains and includes mines from Road Canyon southward to Lime Kiln Canyon. The Star tungsten mine near Harrison Pass Creek is near the center of the district.

Scheelite was discovered in 1916 and mined during the years 1941-44 and 1952-53. Five separate tactite bodies at the Star mine yielded most of the tungsten produced from the district--about 8,000 units of $\mathrm{WO}_{3}$.

Geologic setting and ore deposits

Limestones and shales of the Pogonip Formation of Ordovician age crop out along the lower east slope of the Ruby Mountains in a belt about a mile wide and 6 miles long. They are intruded by the Harrison Pass granodiorite-quartz monzonite stock of Tertiary age which is about 7 miles wide and 10 miles long and forms the summit and west slopes of the range. The district covers the southeastern part of the stock (see also Valley View district).

Near the irmegular east edge of the stock in a north-trending zone about 1,500 ft wide, the limestone is metamorphosed to marble and the shale to hornfels. Along the contact of the intrusive with both the marble and the hornfels, tactite bodies as much as $20 \mathrm{ft}$ wide and $300 \mathrm{ft}$ long crop out at intervals for a distance of about 4,000 ft. Scheelite and a little powellite occur in the tactite. Ore shoots range in width from 1 to $20 \mathrm{ft}$, in length from a few feet to about $100 \mathrm{ft}$, and were mined to depths of a little more than $65 \mathrm{ft}$. They tend to rake along the bedding; some are wider and higher grade opposite beds of hornfels, others opposite marble. The ore shoots are displaced 1-10 ft along many small faults.

Grade of the ore mined ranged from about 0.5 percent to 2.0 percent $\mathrm{WO}_{3}$ and averaged. about 1 percent.

Beryl occurs in the tactite bodies, in the granitic rock immediately adjacent to them, and in the pegmatites in and near the stock, indicating that emanations from the Harrison Pass stock were abnormally rich in beryllium. Of 18 samples (Olson and Hinrichs, $1960, \mathrm{P} .173$ ), the highest grade was 0.056 percent $\mathrm{BeO}$. 


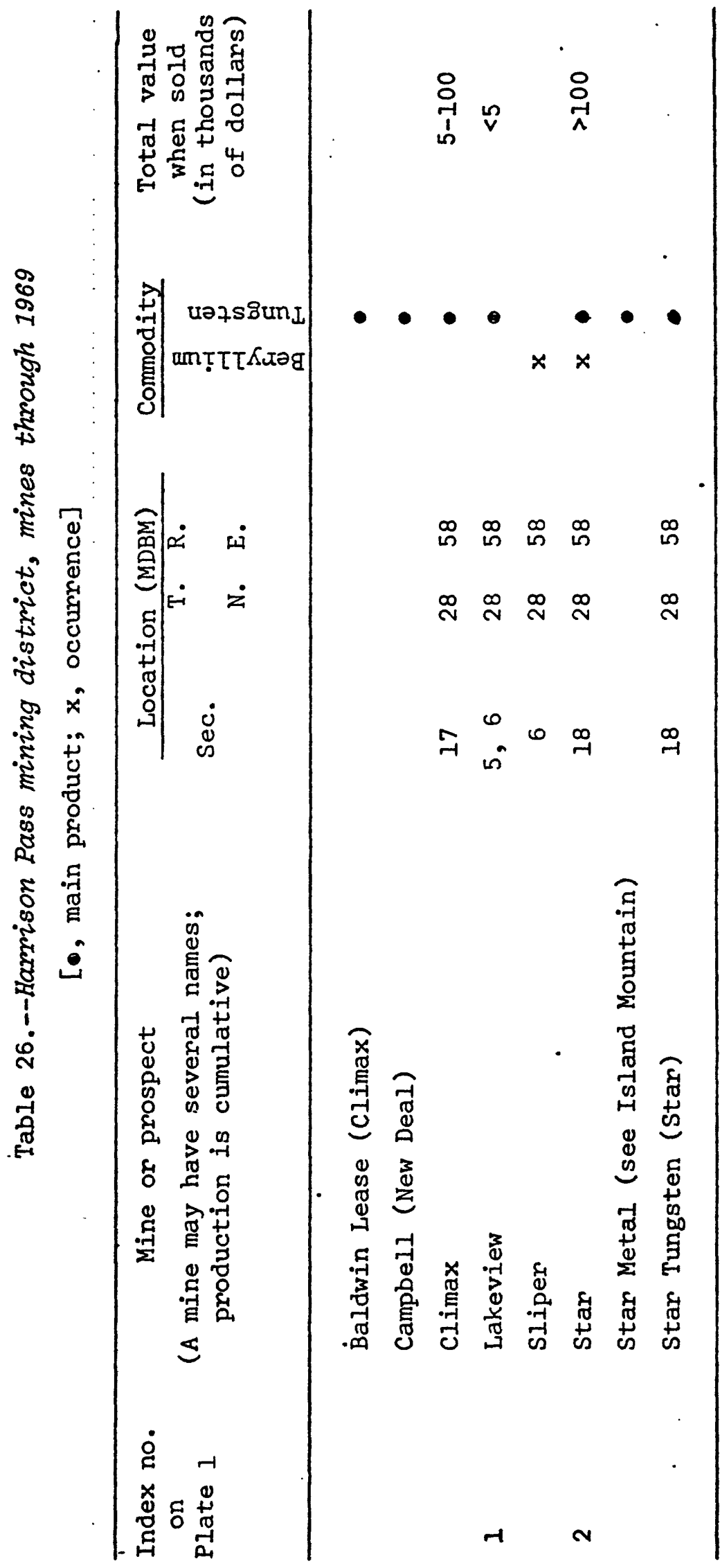


Hicks district

Location and history

\begin{tabular}{|c|c|c|c|}
\hline $\begin{array}{l}\text { Sections } \\
\text { (Approx.) }\end{array}$ & $\begin{array}{l}\mathrm{T} . \\
\mathrm{N} .\end{array}$ & $\begin{array}{l}\text { R. } \\
\text { E. }\end{array}$ & $\begin{array}{l}\text { Quadrangle name } \\
\text { ( } 7 \frac{1}{2} \text { or } 15 \text { minute) }\end{array}$ \\
\hline$S \frac{1}{2}$ & 47 & $54 \frac{1}{2}$ & Mountain City \\
\hline$S \frac{1}{2}$ & 47 & 55 & Mountain City, Rowland \\
\hline$N \frac{1}{2}$ & 46 & $54 \frac{1}{2}$ & Mountain City \\
\hline$N^{\frac{1}{2}}$ & 46 & 55 & Mountain City, Rowland \\
\hline
\end{tabular}

The Hicks district originally included only the Hicks and McDonnell mines, both near McDonald Creek. The exact location is indefinite, but the McDonnell lode and millsite claims (patent survey 37 ) in the Hicks district may be the McDonald mine in sec. 8, T. 46 N., R. 55 E. The townships listed above include Hicks Mountain, Hicks Creek, and Enright Hill, which in some reports may be included in the Mountain City district, and in others under Gold Basin or Alder. Land Office records are listed under Hicks district.

\section{Hot Creek district}

Location and history

\begin{tabular}{llll}
\hline $\begin{array}{l}\text { Sections } \\
\text { (Approx.) }\end{array}$ & $\begin{array}{l}\text { T. } \\
\text { N. }\end{array}$ & E. & $\begin{array}{l}\text { Quadrangle name } \\
\left(7 \frac{1}{2} \text { or } 15 \text { minute }\right)\end{array}$ \\
\hline All & 39 & 59 & Hot Springs Creek, Twin Buttes \\
\hline
\end{tabular}

A Hot Creek mining district in the above township is mentioned in a list of thermal springs by Waring (1965, p. 33), who cites Gilbert (1875, p. 152); Gilbert included the district in a list but did not specify its location. He may have been referring to the Hot Creek (Tybo) district at the town of Hot Creek in the Hot Creek Range in Nye County. There are no mines in the above township in Elko County, but a group of warm springs discharge into Hot Springs Creek.

Huntington Creek district

Location and history

\begin{tabular}{lllll}
\hline $\begin{array}{l}\text { Sections } \\
\text { (Approx.) }\end{array}$ & $\begin{array}{l}\text { T. } \\
\text { N. }\end{array}$ & $\begin{array}{l}\text { R. } \\
\text { E. }\end{array}$ & $\begin{array}{l}\text { Quardangle name } \\
\left(7 \frac{1}{2} \text { or } 15 \text { minute }\right)\end{array}$ & Remarks \\
\hline SW $\frac{1}{4} 18$ & 31 & 56 & Lee & Mineral Soap mine \\
\hline
\end{tabular}




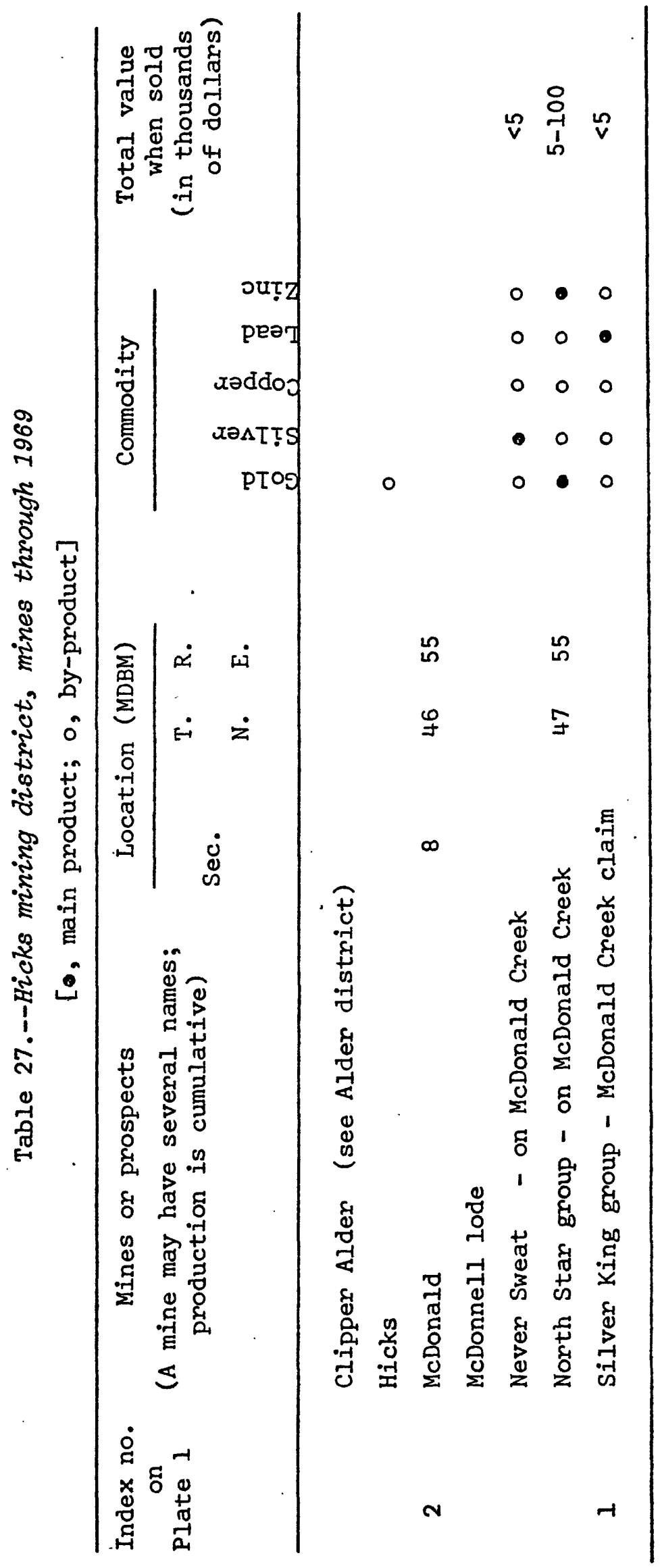


There is only one mine in this area, the Huntington Creek clay mine, which is 4 miles south of Twin Bridges along the lower slope of the ridge $150 \mathrm{ft}$ high that borders the east side of Huntington Creek and is about $20 \mathrm{ft}$ above the nearly level valley floor.

The clay deposit was discovered in 1875 (Thompson and West, 1881, p. 396) and was operated as the Mineral Soap mine until about 1900 (Patterson, 1964, p. 57). A few carloads were shipped to the west coast in 1927, and some additional testing may have been done in 1940 (Papke, 1970, p. 19).

The mine consists of two parallel adits $25 \mathrm{ft}$ apart driven southeastward about $50 \mathrm{ft}$ and connected underground by a horizontal stope extending to the end of the adits. A 75-foot prospect adit $100 \mathrm{ft}$ south and another short adit $300 \mathrm{ft}$ north were apparently not productive.

\section{Geologic setting and ore deposits}

The clay deposit is a discontinuous bed of swelling bentonite as much as $2 \mathrm{ft}$ thick interbedded with 4-8 ft of sandy clay in a conglomerate stratum $50 \mathrm{ft}$ thick of the Humboldt Formation of Miocene age. The beds dip southward at low angles or are locally horizontal. The bentonite is composed largely of montmorillonite but contains variable small amounts of feldspar, quartz, calcite, and mica. Selected samples have good plastic viscosity and swelling characteristics.

Island Mountain district

Location and history

\begin{tabular}{|c|c|c|c|c|}
\hline $\begin{array}{l}\text { Sections } \\
\text { (Approx.) }\end{array}$ & $\begin{array}{l}\mathrm{T} . \\
\mathrm{N} .\end{array}$ & $\begin{array}{l}\text { R. } \\
\text { E. }\end{array}$ & $\begin{array}{l}\text { Quadrangle name } \\
\left(7 \frac{1}{2} \text { or } 15 \text { minute }\right)\end{array}$ & Other district names \\
\hline 36 & 45 & 55 & Rowland & \\
\hline $14,15,16$ & 45 & 56 & Rowland & \\
\hline$S^{\frac{1}{2}}$ & 45 & 56 & Rowland & Wyoming \\
\hline All & 44 & 55 & Wild Horse, Mt. Velma & Gold Creek, Penrod \\
\hline$W-2 / 3$ & 44 & 56 & Mt. Velma & Gold Creek, Penrod \\
\hline
\end{tabular}

The Island Mountain district extends northeast and southwest from Island Mountain (Mt. Velma quadrangle) to include most of the drainage basin of Penrod Creek. Its northem border with the Alder district, however, is an east-west line through the summit of Tennessee Mountain except on the southwest slope where the Gamet Tungsten mine is considered to be in the Alder district (pl. 1). Its eastern border with the Charleston district is the drainage divide from Haystack Mountain through Cornwall Mountain, except on the northeast slope of Cornwall Mountain where the St. Elmo mine is in the Island Mountain district. 
Silver-, copper-, and antimony-bearing quartz veins were found in 1869 on the southwest slope of Silver (Rosebud)Mountain whereupon the Mardis claim, now the Diamond Jim mine, was located, and the Wyoming district was organized. A brief silver rush followed; the city of Bruno near sec. 28 , T. 45 N., R. 56 E. on Crystal (Martin) Creek was established and hundreds of lots were sold; the Mardis mill was built on the west bank of the creek in 1875, but by 1880 the population of Bruno had dwindled to 20 persons (F. W. Lewis, written commun., 1973).

The Island Mountain district was organized in 1873 to include placer deposits along Gold Creek and two of its tributaries, Hammond and Coleman Canyons. Placer claims were located also along Penrod, Big Bend, Poorman, Mill, and Martin Creeks. The placer mining camp of Penrod on the east side of Gold Creek (sec. 7, T. 44 N., R. 56 E.) flourished until about 1878, then declined to only a few buildings. "In 1896 the Gold Creek Mining Company--a New York stock corporation--was organized, the new town of Gold Creek [sec. 18, T. 44 N., R. 56 E.] surveyed and platted on the other side of the ridge from the Penrod home, and a mad mining boom was under way* **" (Murbarger, 1957, p. 18). The Sunflower reservoir was built to impound the waters of Gold Creek for hydraulicking, but the ditch to the placers was never completed, and the boom fizzled out early in 1898.

Production of placer gold from its discovery in 1873 through 1901 is estimated to be about $40,000 \mathrm{oz}$ (Johnson, 1973, p. 97). From 1902 through 1958 recorded production is $740 \mathrm{oz}$ of gold and $252 \mathrm{oz}$ of silver. No placer production was reported during 1959-69. The most productive lode deposits, the Rosebud and Diamond Jim group, were not mined intensively until 1950 and 1954. Lode production of gold, silver, copper, lead, and zinc was first recorded in 1934; about 95 percent of the total was from the Diamond $\mathrm{Jim}$ and Rosebud mines (table 28) during 1954-69. Antimony was shipped during 1941-51 from the Star Metal (Gribble Antimony) mine. A 35-foot shaft has since been covered by bulldozing.

\section{Geologic setting and ore deposits}

The oldest rock in the district is Prospect Mountain(?) Quartzite of Lower Cambrian age. It is overlain by conglomerates, sandstones, limestones, and shales of younger Paleozoic and Permian ages. All of these formations are intruded by a large stock of quartz monzonite (Coffee Pot stock) of Cretaceous(?) age, most of which crops out north of the district (see Alder district).

Between Hammond and Coleman Canyons, limestones and siltstones of the Hammond Canyon Formation (Permian) are intruded by a smaller stock about a mile across, also of quartz monzonite (Coash, 1967, pl. 1). Near the stocks they are also intruded by dikes of aplite and alaskite; the limestone is metamorphosed to marble or tactite and the shales to phyllite or argillite. Locally these formations are successively overlain by erosion remnants of the Bieroth Andesite, Jarbidge Rhyolite, and the Young American Gravel of Miocene age, and by the Idavada Volcanics of late Miocene age (Bushnell, 1967). 


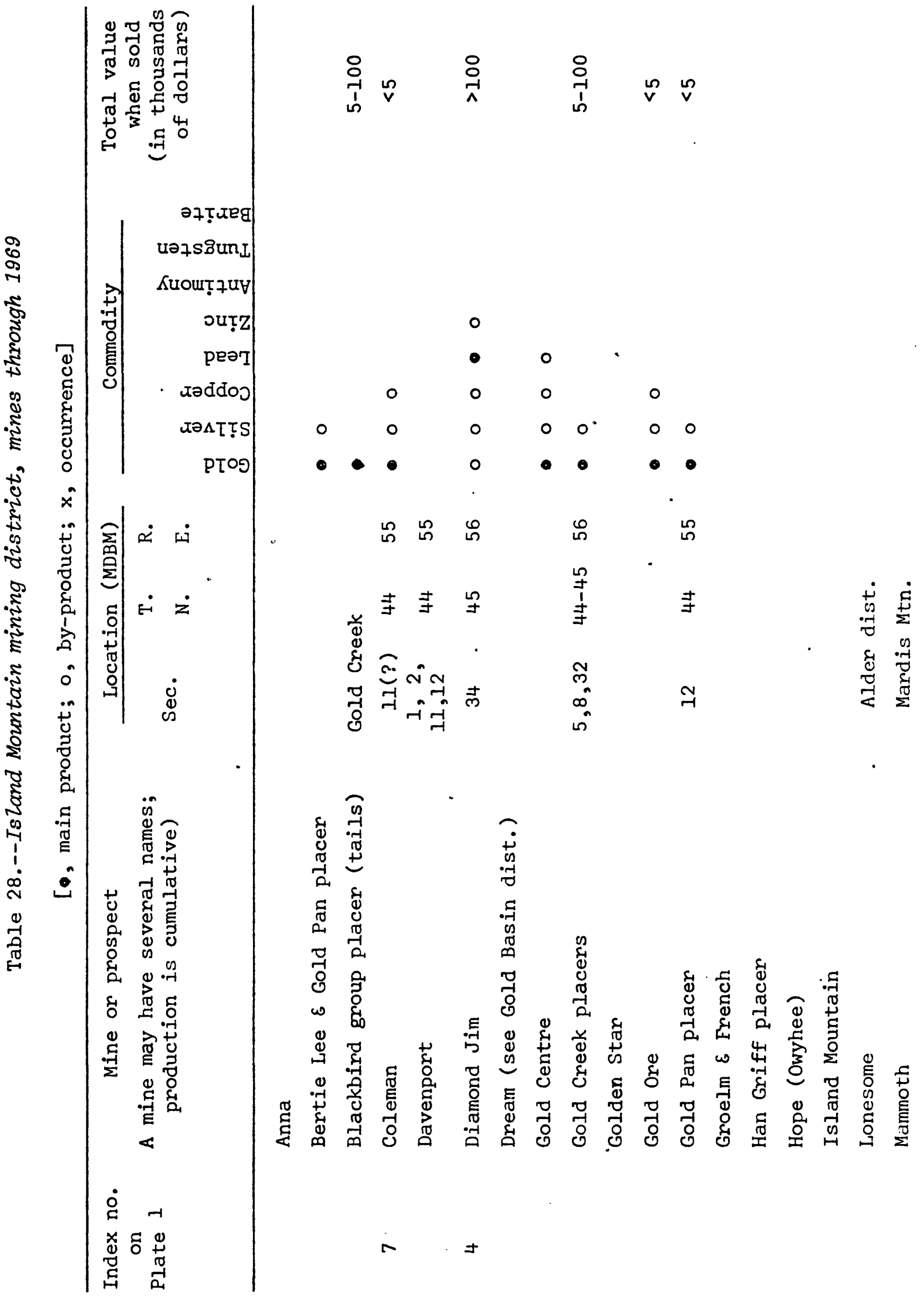




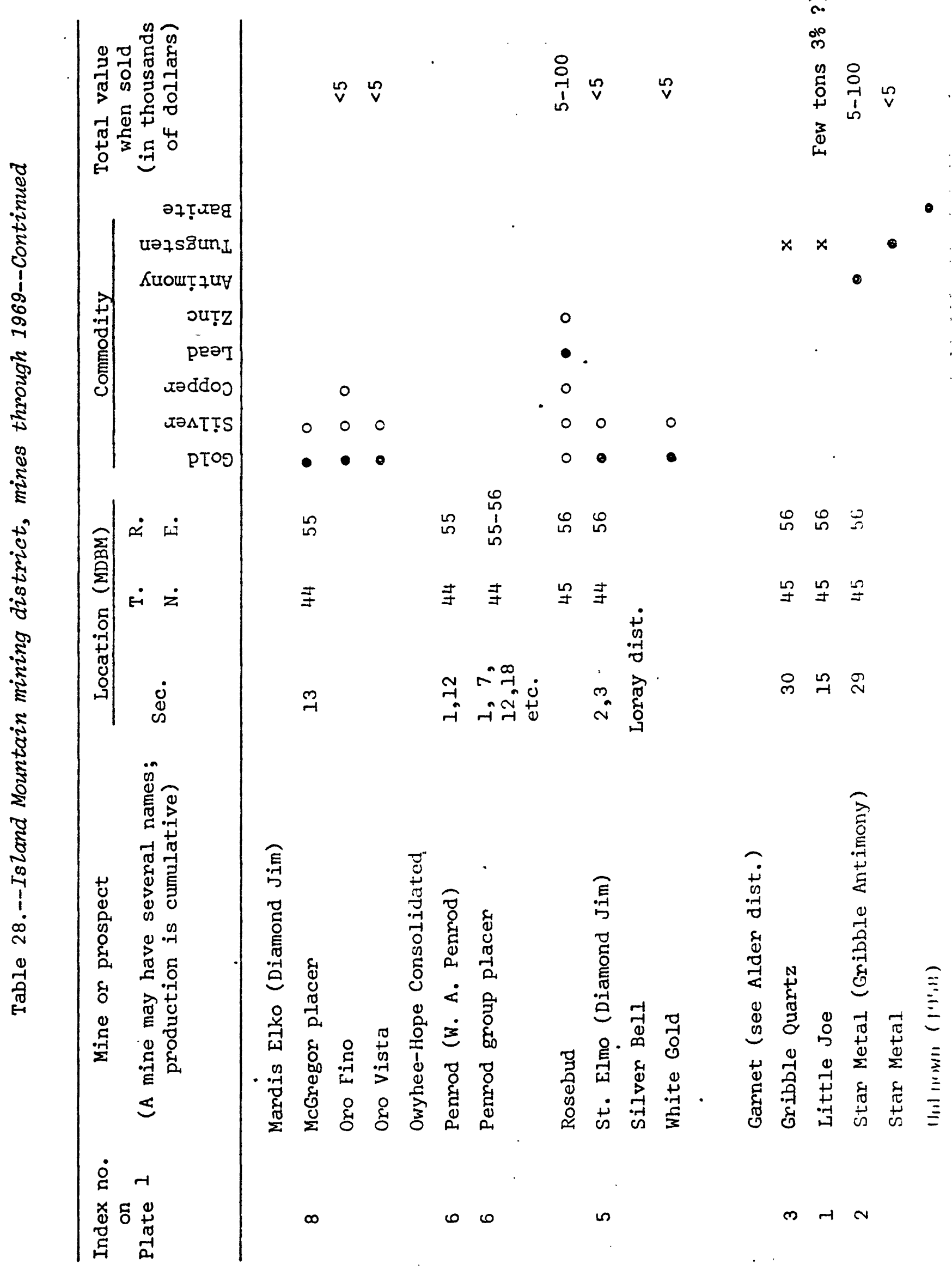


The pre-Tertiary rocks are folded and together with the older volcanics are displaced along two sets of steeply dipping faults. One set strikes northeast, the other northwest. Mineralized quartz veins occupy some of both sets of faults but only in the pre-Tertiary rocks.

The ore deposits are quartz veins along fault, tactite bodies near the intrusives, and placers in gravels of two different ages.

The most productive quartz vein is along a northwest-striking fault contact which dips $45^{\circ} \mathrm{SW}$. between a hanging wall of phyllite and a footwall of Prospect Mountain(?) Quartzite (Diamond Jim mine). "The ore consists of silver and lead sulphides in a quartz gangue which occurs as cavity fillings and minor replacements in small pockets, veins, stringers, and lenses, in a zone about 9 feet thick ***" (Bushnell, 1967, p. 34).

At the Star Metal mine, a stibnite-bearing quartz vein up to 4 inches wide was exposed in the shaft but could not be traced laterally. Small lenses of stibnite rarely more than 2 inches thick occur in the walls for $2 \mathrm{ft}$ or more on each side of the vein. The vein is in a breccia zone 6-18 inches, wide along a bedding-plane fault in a wide, steeply northdipping shear zone in thin-bedded limestone and phyllitic shale of the Tennessee Mountain Formation of Pennsylvanian age. Three other faults in the same shear zone contain stringers of calcite and scheelite. The scheelite is white to tan grains completely surrounded by stibnite. One 1 - by 2 - by 6 -inch pod contained almost 85 percent scheelite; closely spaced pods form ore shoots several feet long. Near the surface, white and yellow antimony oxides stain the stibnite-bearing stringers, and small amounts of the red oxysulfide are present. Fifteen tons of ore shipped in 1941-42 contained 41 percent Sb (Lawrence; 1963, p. 52).

Contact metamorphic deposits of tactite contain pyrite, chalcopyrite, scheelite, and molybdenite. They are similar to those in the Alder district but of lower grade.

Placer deposits are of two different ages, Miocene and Holocene. Most of the older placer deposits, including all of the largest ones, are in the Young American Gravel as much as half a mile from and $50 \mathrm{ft}$ higher than the present streams. They contain well-rounded quartz boulders $3 \mathrm{ft}$ or more in diameter--too large to have been deposited by the intermittent streams in Hammond and Coleman Canyons, or by Gold Creek--and they cover areas several miles long and more than a hundred feet across--too extensive to have been deposited by those streams. The older gravels contain gold where they are relatively close to the Coffee Pot stock. Holocene placers are in and along the small modern streams. The gold was derived in part from the older placers and to a lesser extent from quartz veins in and near the stock. 
Ivanhoe district

Location and history

\begin{tabular}{lllll}
\hline $\begin{array}{l}\text { Sections } \\
\text { (Approx.) }\end{array}$ & $\begin{array}{l}\text { T. R. } \\
\text { N. E. }\end{array}$ & $\begin{array}{l}\text { Quadrangle name } \\
\text { ( } 7 \frac{1}{2} \text { or } 15 \text { minute) }\end{array}$ & Other district names \\
\hline All & 38 & 47 & Squaw Valley Ranch & Battle Mountain \\
All & 38 & 48 & Willow Creek Reservoir & Battle Mountain \\
All & 37 & 47 & Rock Creek Ranch & Battle Mountain \\
All & 37 & 48 & Willow Creek Reservoir SE & Battle Mountain \\
\hline
\end{tabular}

The Ivanhoe district includes the drainage basins of Ivanhoe and Little Antelope Creeks in the Butte Creek Range about $45 \mathrm{miles}$ by road north and a little east of Battle Mountain.

Mercury ore was discovered in the district in 1915, and 20 flasks of mercury was, produced from the Ivanhoe mine in 1916-17. The next recorded production was from the Sheep Camp mine in 1928. Thereafter some mercury was recovered in nearly every year through 1947, more than a third of it in 1943 from the Silver cloud mine. A few flasks were produced each year from 1957 through 1962 and a few in 1966.

\section{Geologic setting and ore deposits}

The oldest rocks in the district--exposed near the Hatter and Redboy mines--are gray, thin-bedded to massive quartzite and chert (western assemblage) of the Valmy Formation of Ordovician age. They are unconformably covered throughout most of the district by volcanic rocks of oligocene to Pliocene ages that are divided into two groups. The older group consists of platy rhyolites, basalt, rhyolitic ash, tuff, and fanglomerate, ranging in total thickness from a few feet to about 1,500 ft. The younger group, lying unconformably on the older, is composed of quartz-rich rhyolite, tuff, and ash about 1,000 ft thick (Bailey and Phoenix, 1944, p. 55-63).

The quartzites are tilted steeply, the older volcanics dip $10^{\circ}-30^{\circ} \mathrm{E}$., and the younger volcanics are nearly flat. All three formations are cut by normal faults, two sets of which are prominent. In one set the faults trend northward and dip west, in the other they trend eastward and dip either north or south. Displacements along the north-trending faults are as much as $300 \mathrm{ft}$. Near the faults the volcanic strata are folded, in some places quite sharply. Near some of the faults the tuff and ash beds of the older volcanics are opalitized and locally mineralized with cinnabar.

The mineralized bodies are veins along steep north-trending faults and disseminated deposits in opalitized rhyolitic ash and tuff beds near the faults. The ore shoots that have been mined are relatively flat blanket deposits of cinnabar-bearing opalite in and along folds in the volcanic strata. They range in thickness from 2 to $15 \mathrm{ft}$ and are as much as $800 \mathrm{ft}$ wide and $1,500 \mathrm{ft}$ long. 


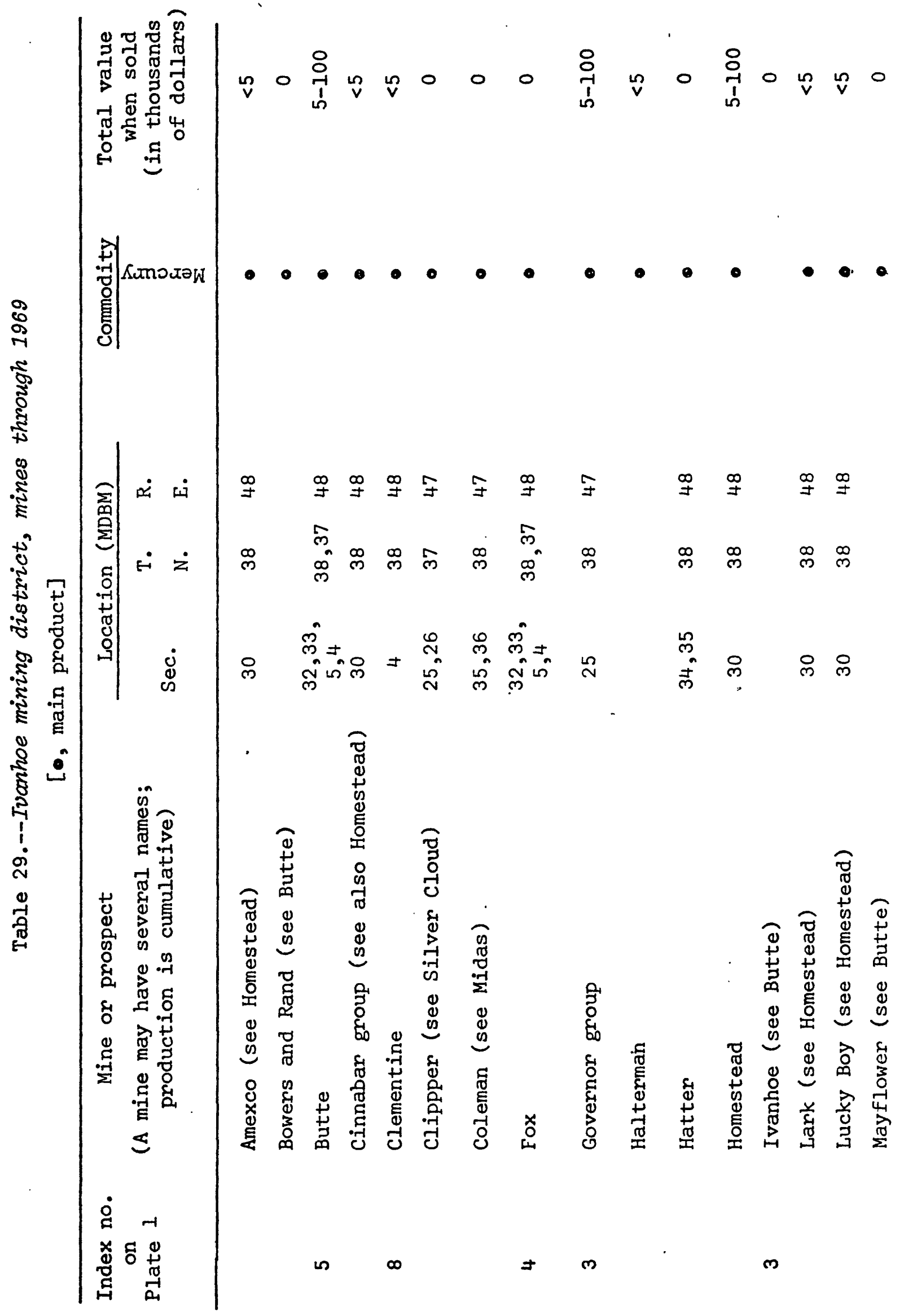




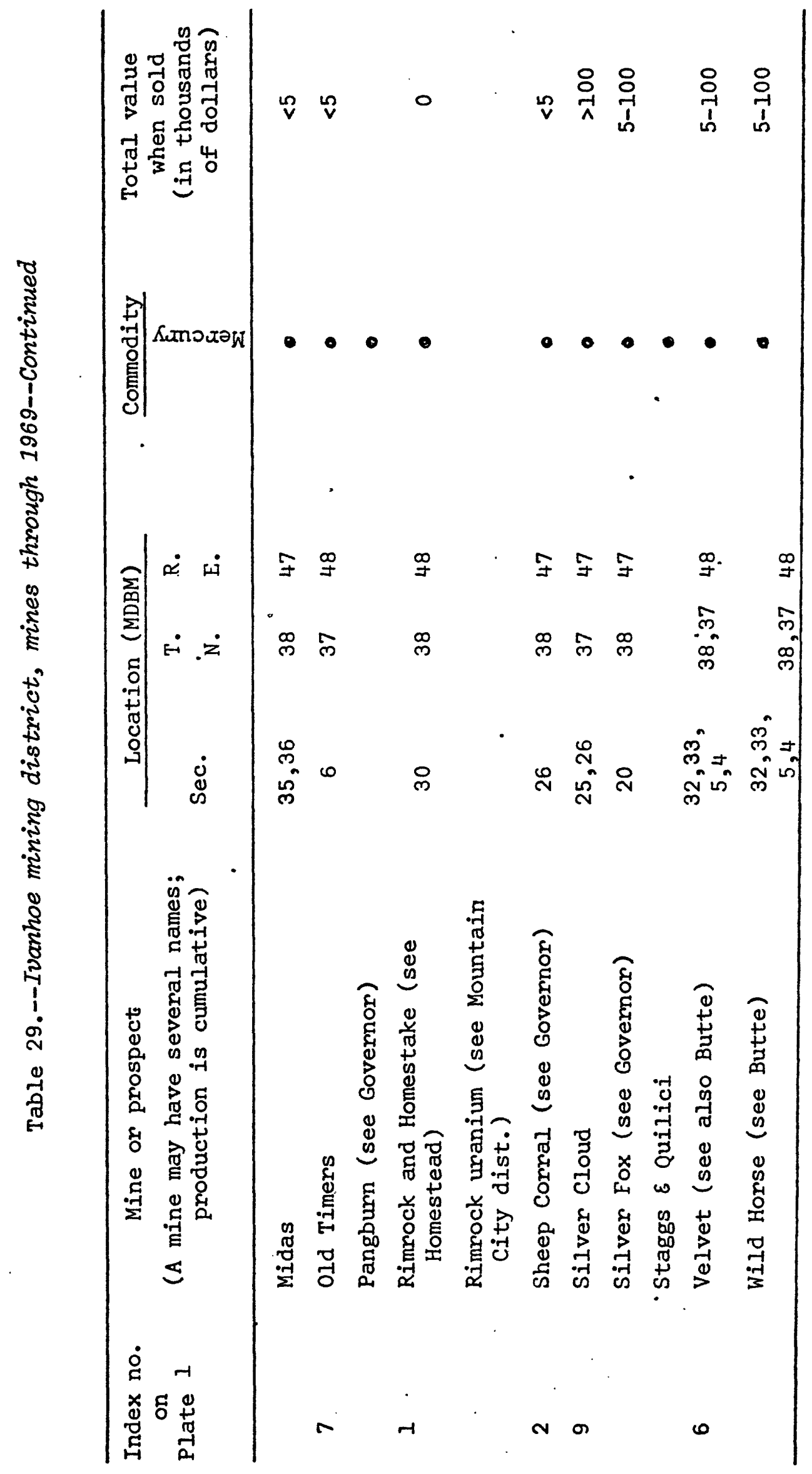


The main ore mineral in the district is cinnabar; calomel and native mercury have been found in small amounts. The cinnabar occurs finely disseminated in opalite or coating the walls of pore spaces and fractures. Other gangue minerals are chalcedony, alumite, montmorillonite, and rarely sulfur, barite, and quartz.

Grade of the deposit at the Silver Cloud mine ranged from a trace to $20 \mathrm{Ib}$ of mercury per ton and averaged about $5 \mathrm{lb}$ (H. K. Stager, written commun., 1969 ).

Jarbidge district

Location and history

\begin{tabular}{|c|c|c|c|c|}
\hline $\begin{array}{l}\text { Sections } \\
\text { (Approx.) }\end{array}$ & $\begin{array}{l}\text { T. } \\
\text { N. }\end{array}$ & $\begin{array}{l}\text { R. } \\
\text { E. }\end{array}$ & $\begin{array}{l}\text { Quadrangle name } \\
\text { ( } 7 \frac{1}{2} \text { or } 15 \text { minute) }\end{array}$ & Remarks \\
\hline$E^{1} \frac{1}{2}$ & 46 & 57 & Rowland, Jarbidge & \\
\hline All & .46 & 58 & Jarbidge & Original discoveries \\
\hline A11 & 46 & 59 & Jarbidge & \\
\hline $\mathrm{NE}-3 / 4$ & 45 & 58 & Jarbidge & \\
\hline All & 45 & 59 & Jarbidge & \\
\hline$E-2 / 3$ & 44 & 58 & Marys River Basin NE & \\
\hline AIl & 44 & 59 & & Sun Creek district (sec. 20) \\
\hline
\end{tabular}

Schrader (1923, p. 1) defined the district to be "within an area about 14 miles square, extending a few miles west of the main Jarbidge River and east of the East Fork ***." He concluded, however, that mineral-bearing rocks (older rhyolite) comprise an area about 20 miles square. Mines as far south as the Young America (table 30) have been recorded in the district, which in this report includes the south two-thirds of the Jarbidge quadrangle (except the southwest corner which is in the Charleston district) and north one-third of the Marys River Basin NW. and NE. quadrangles to the south. A small part of the east-central Rowland quadrangle is also included.

A few prospect pits may have been dug in the late 1860 's, and the first specimen of gold-bearing quartž was found in 1904, but minable deposits were first found in 1909 in the Boume, Pavlak, Buster, and Pick and Shovel veins. The Jarbidge gold rush of 1910 resulted from newspaper reports in February of that year that the Bourne mine had over $\$ 27$ million worth of gold in sight. By April a stampede of more than 1,500 people on snowshoes staked over 500 claims covering almost the entire area. It was soon learned (Schrader, 1912, p. 14-19), however, "that the reports of the Bourne property were grossly exaggerated, and accordingly, in May, a great exodus took place, the emigrants criticizing the country as they went out ***." 
The district went on to produce over $\$ 10$ million in gold and silver, most of it from the Long Hike, North Star, Starlight, and $0 . K$. mines (Elkoro Mines Co.) during 1917-32, making it the third most productive district in the county and, in 1919, the largest gold producer in the state. Only about $10 \mathrm{oz}$ of placer gold was produced (Johnson, 1973, p. 97). Since 1949 only the 0.K., Payday, and Starlight gold mines were active. Tungsten ore was shipped from the Rowland mine during 1943; a few hundred units of $\mathrm{WO}_{3}$ was produced from the district between 1943 and 1956. During 1956 and 1957 barite was produced from the Wildcat mine in the Sun Creek part of the district (table 30 ). No production of metals was reported for the district for the years 1962-69.

\section{Geologic setting and ore deposits}

The basement rocks in the Jarbidge quadrangle (Coats, 1964, p. MI) are Precambrian(?) schist, quartzite, and hornfels, Cambrian Prospect Mountain(?) quartzite, Paleozoic(?) Iimestone, silty limestone, chert, phyllite, and quartzite intruded by Cretaceous quartz monzonite of the Coffee Pot stock. Near the stock the argillaceous rocks are metamorphosed to homfel's and the limestones to tactite. These formations are exposed only along the west side of the quadrangle, except for two fault slivers of Prospect Mountain(?) Quartzite $1 \frac{1}{2}$ miles southeast of Jarbidge.

The eroded surface of the basement rocks is overlain by Tertiary tuffs, local conglomerates, and Jarbidge Rhyolite (older rhyolite of Schrader, 1923) which covers most of the south half of the quadrangle and is locally more than 2,000 ft thick. The older rhyolite is overlain unconformably by dacite flows and tuffs, local gravels, and by Cougar Point Welded Tuff (younger rhyolite), which covers most of the north half of the quadrangle and is as much as $1,500 \mathrm{ft}$ thick. The younger rhyolite is locally overlain by basalt flows $105 \mathrm{ft}$ thick or less. In a few places the Tertiary rocks are overlain by Pleistocene glacial deposits and by Holocene landslide, talus, and alluvial deposits.

The basement rocks are displaced along pre-Cretaceous faults, largest of which is the Copper Mountain thrust inferred to underlie much of the westem half of the quadrangle at depths of 1,000-6,000 ft (Coats, 1964, pl. 1). Cambrian and Precambrian rocks are thrust over and rest upon the Paleozoic sedimentary rocks. The early Tertiary volcanics and conglomerates are displaced along normal faults represented by the Copper Creek fault, which dips gently east and places both Precambrian and Tertiary formations on Prospect Mountain(?) Quartzite. The Jarbidge Rhyolite (Miocene) and all older formations are displaced along three sets of faults that dip steeply: one set strikes northward, one northeast, and one northwest. These three sets of faults are locally mineralized. The Cougar Point Welded Tuff (late Miocene) is cut by a relatively few faults which may have resulted from postmineral movements (Pliocene?) along some of the premineral faults. 


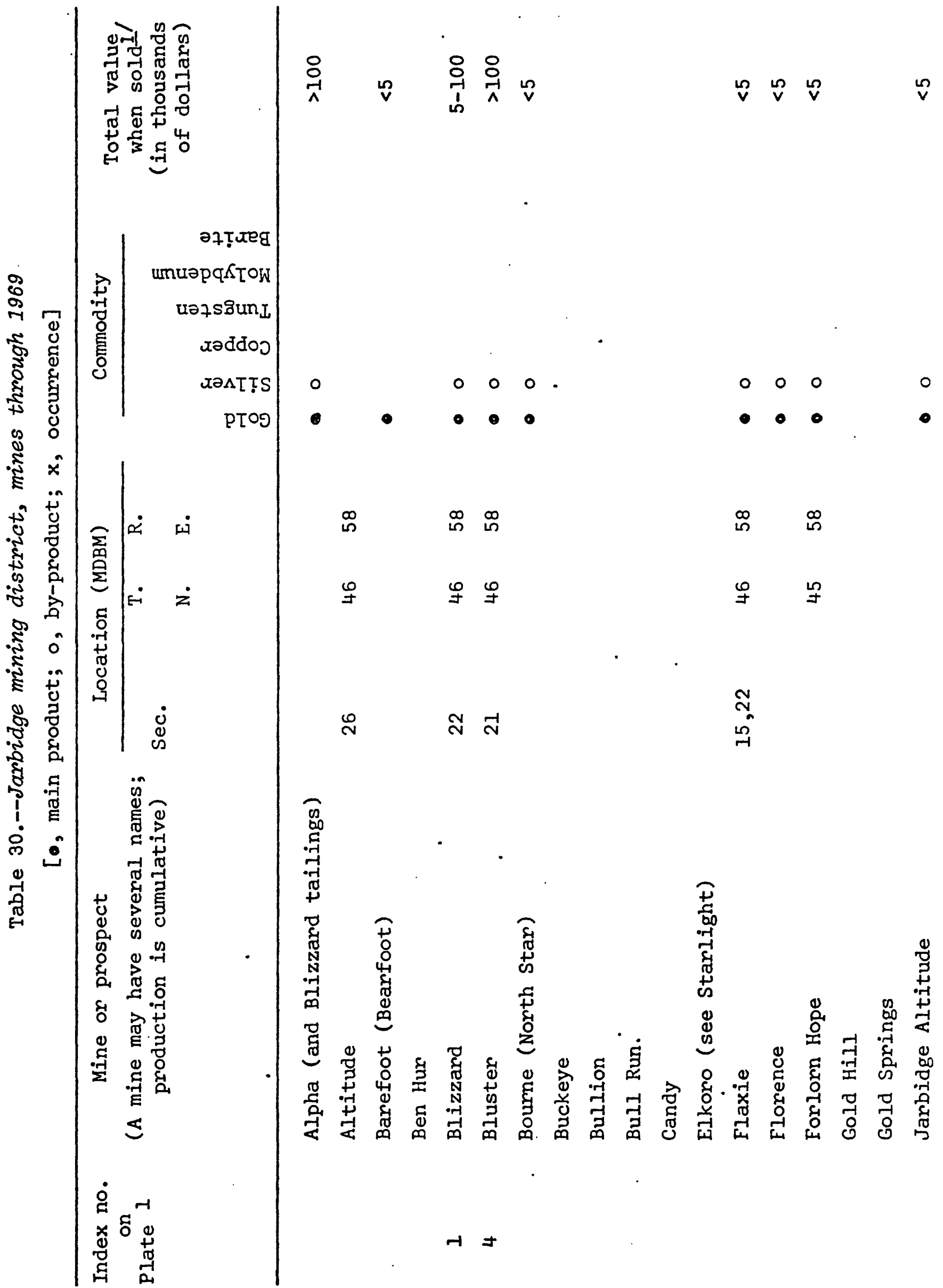




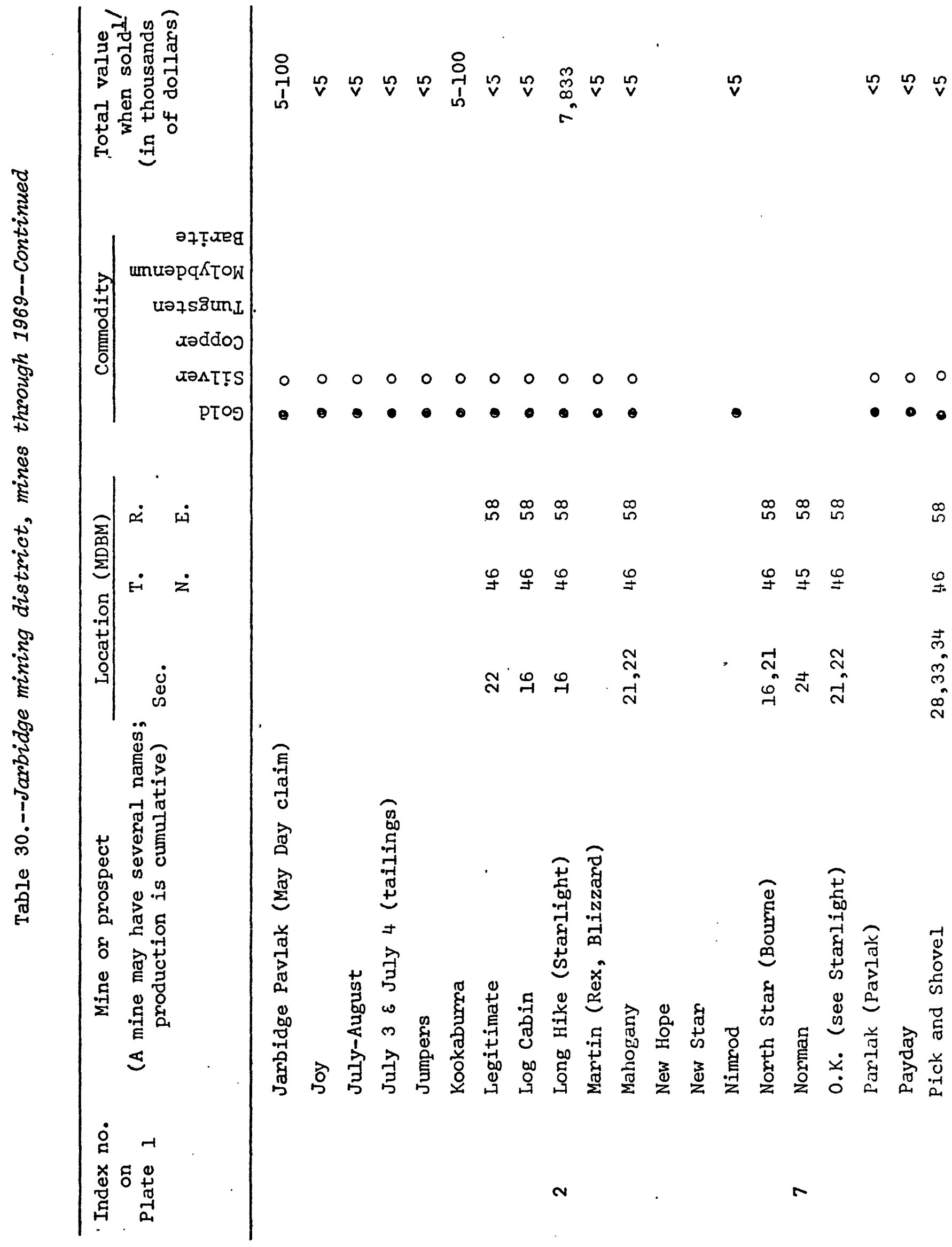




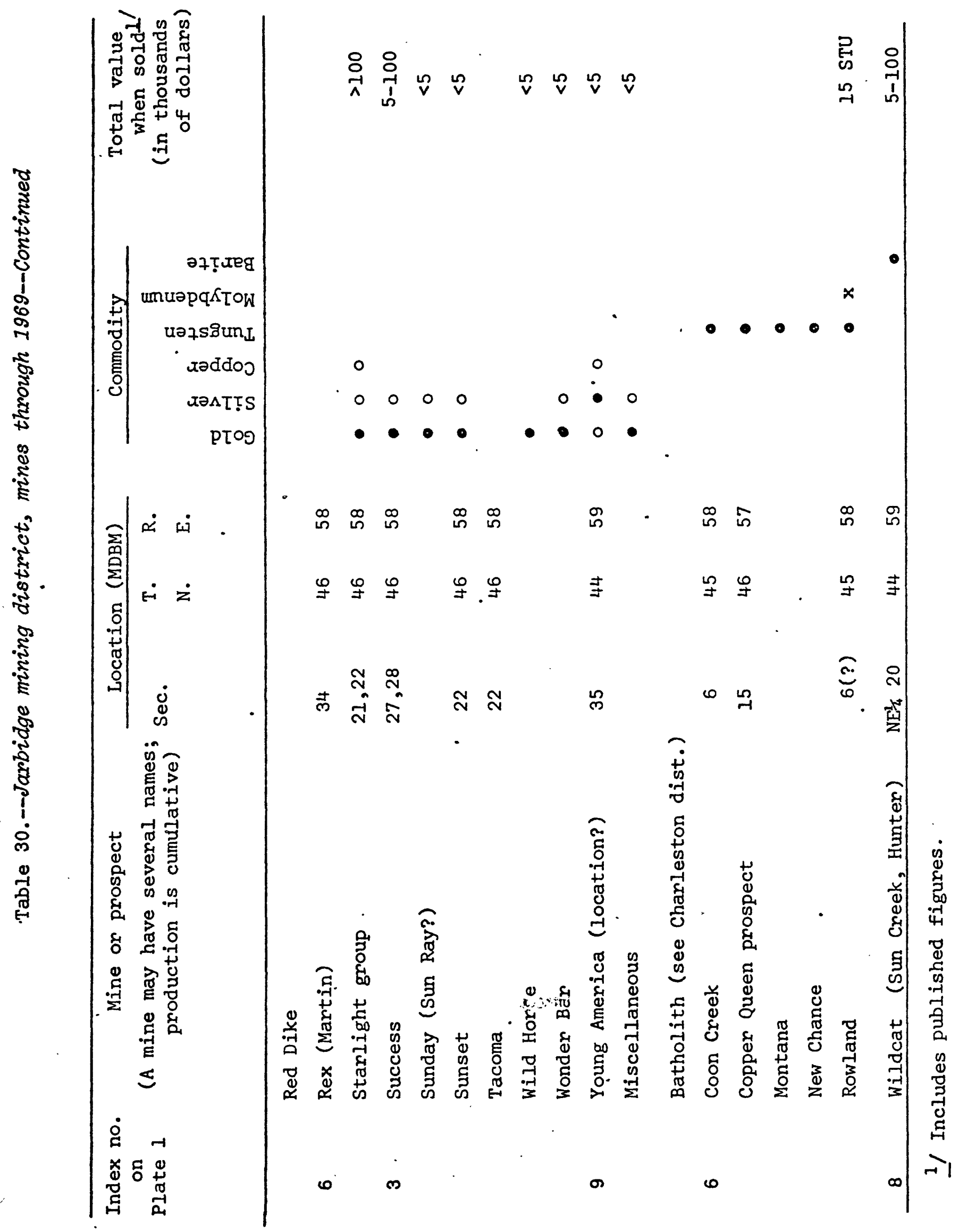


The ore bodies in the Jarbidge district are of three types and ages, contact metamorphic deposits of Cretaceous age, quartz-adularia veins or lodes of Tertiary age, and barite veins of Tertiary age. The contact metamorphic ore bodies are tungsten-molybdenum deposits in tactite zones as much as $100 \mathrm{ft}$ wide near the Coffee Pot stock. About 4.5 tons of sorted tungsten ore consisting of coarse crystals of scheelite accompanied by molybdenite and powellite in garnet tactite contained 3.8 percent $\mathrm{WO}_{3}$ (D. M. Lemmon, written commun., 1948).

Quartz veins along northwest-striking normal faults in the quartzite, limestone, and quartz monzonite are small and have not been extensively worked. The principal gold-silver ore bodies in the district are lodes or reefs, locally called "dikes," along all three sets of steep normal faults in the Jarbidge Rhyolite. The lodes consist of sheared and altered rhyolite in fault zones as much as $40 \mathrm{ft}$ wide which contain stringers and veins generally less than $3 \mathrm{ft}$ wide of calcite partly or wholly replaced by quartz and (or) adularia. The rhyolite is silicified as much as $100 \mathrm{ft}$ on each side of the lodes, but within the shear zones (lodes), alteration is more intense. Postmineral movements resulted in highly sheared lodes accompanied by gouge, which localized some of the secondary silver minerals and also faulted off some of the ore shoots. The ore shoots were a fraction of an inch to about $40 \mathrm{ft}$ wide, as much as $1,000 \mathrm{ft}$ long, and were mined 1,250 ft or less down the dip. Although the entire width of the lodes was mineralized in places, the highest grade ores occurred in pockets or veinlets along or across the lodes. One of the richest veinlets was in the Pavlak Iode where (Schrader, 1912, p. 69) "a more or less persistent streak about half an inch in width $* * *$ was said to range from $\$ 5,000$ to $\$ 10,000$ to the ton."

Gangue minerals are quartz, adularia, chlorite-epidote, halloysite and other clays, and smaller amounts of apatite, barite, calcite, chalcedony, fluorite, hematite, hyalite, kaolin, leverrierite, limonite, psilomelane, pyrolusite, marcasite, muscovite, opaline silica, orthoclase, pyrite, sericite, and talc. As oxidation extends to depths of $800 \mathrm{ft}$ or more, supergene halloysite and other clay minerals are abundant.

Primary ore minerals in the lodes are free gold, electrum, argentite, chalcopyrite, pyrargyrite, and naumannite, but most of the ore mined was oxidized and was valued chiefly for its gold content. The gold particles range in size from microscopic to plates larger than a man's hand and as thick as a knife blade (Schrader, 1923, p. 31). Grade of the ore ranged widely to as much as $50 \mathrm{oz}$ of gold and $90 \mathrm{oz}$ of silver per ton, but the average was about $0.5 \mathrm{oz}$ gold and $1.4 \mathrm{oz}$ silver per ton. In the early days the ore was mined selectively and sorted in an effort to obtain a shipping grade of about $\$ 1,000$ per ton.

Barite was mined in only one locality in the district. At the Wildcat (Sun Creek, Jensen and Steele, Hunter) mine. Coarsely crystalline barite occurs in a vein a few feet to $25 \mathrm{ft}$ wide in silicified argillite (Horton, 1963, p. 6) of Ordovician age. 


\section{Kinsley district}

Location and history

\begin{tabular}{llllll}
\hline Sections & T. & R. & Quadrangle name & Remarks \\
(Approx.) & N. & E. & & \\
\hline$E^{\frac{1}{2}}$ & 26 & 67 & Elko $2^{\circ}$ & Elko and White Pine Counties \\
$W^{\frac{1}{2}}$ & 26 & 68 & Elko $2^{\circ}$ & Elko and White Pine Counties \\
\hline
\end{tabular}

The Kinsley district covers the south half of the Kingsley Mountains, formerly called the Antelope Mountains, the southem end of which is in White Pine County. Silver-bearing lead-copper deposits were first discovered and the Antelope district organized in 1862, but the miners were driven out by the Mormons in 1863 before any ore was produced. The veins were rediscovered about 1865 by George Kingsley and the Kingsley district-known thereafter as the Kinsley district--was organized. Production, mostly from White Pine County was intermittent through 1955. Scheelite was discovered in the Elko part of the district in 1939 and a few tens of units of $\mathrm{WO}_{3}$ was produced between 1942 and 1945. In 1966 a marble deposit high on the southwest slope of the range in Elko County was developed.

\section{Geologic setting and ore deposits}

Most of the southem half of the Kingsley Mountains is composed of dolomitic limestone strata of Cambrian age which dip $5^{\circ}-40^{\circ} \mathrm{E}$. The north end of the range, north of the district, consists mainly of Pogonip limestone of Ordovician age in the upper plate of a thrust fault. The Cambrian limestones at the south end of the range are intruded by a stock about a mile across of quartz monzonite of probable Tertiary age and by radiating dikes of quartz monzonite and aplite. Near the stock the limestones are locally metamorphosed to tactite and at greater distances to lime silicates or marble.

The copper, lead, and silver ore bodies are contact metamorphic deposits in silicated limestone and veins and replacement deposits near the stock along steep north- and east-striking faults and in adjacent gently dipping limestone beds. The largest stope was $50 \mathrm{ft} l o n g$ and $18 \mathrm{ft}$ wide, and the deepest shaft, the Morning Star (table 31), was $275 \mathrm{ft}$ deep, but most of the ore was in small pods. Cerussite, chrysocolla, malachite, azurite, chalcocite, and cerargyrite with a little residual galena and chalcopyrite occur in a gangue of quartz, limestone, tremolite, wollastonite, gamet, limonite, and pyrite.

The tungsten ore bodies are all of contact-metamorphic origin. Largest of these, on the Kerong patented claim at the north edge of the stock, is a tactite body along a granitic dike. The tactite is $5 \mathrm{ft}$ wide, $80 \mathrm{ft}$ long and was mined to a depth of $30 \mathrm{ft}$ or more. Scheelite and a little powellite occur in the tactite. About 7 tons of sorted ore was shipped (D. M. Lemmon, written commun., 1948). 


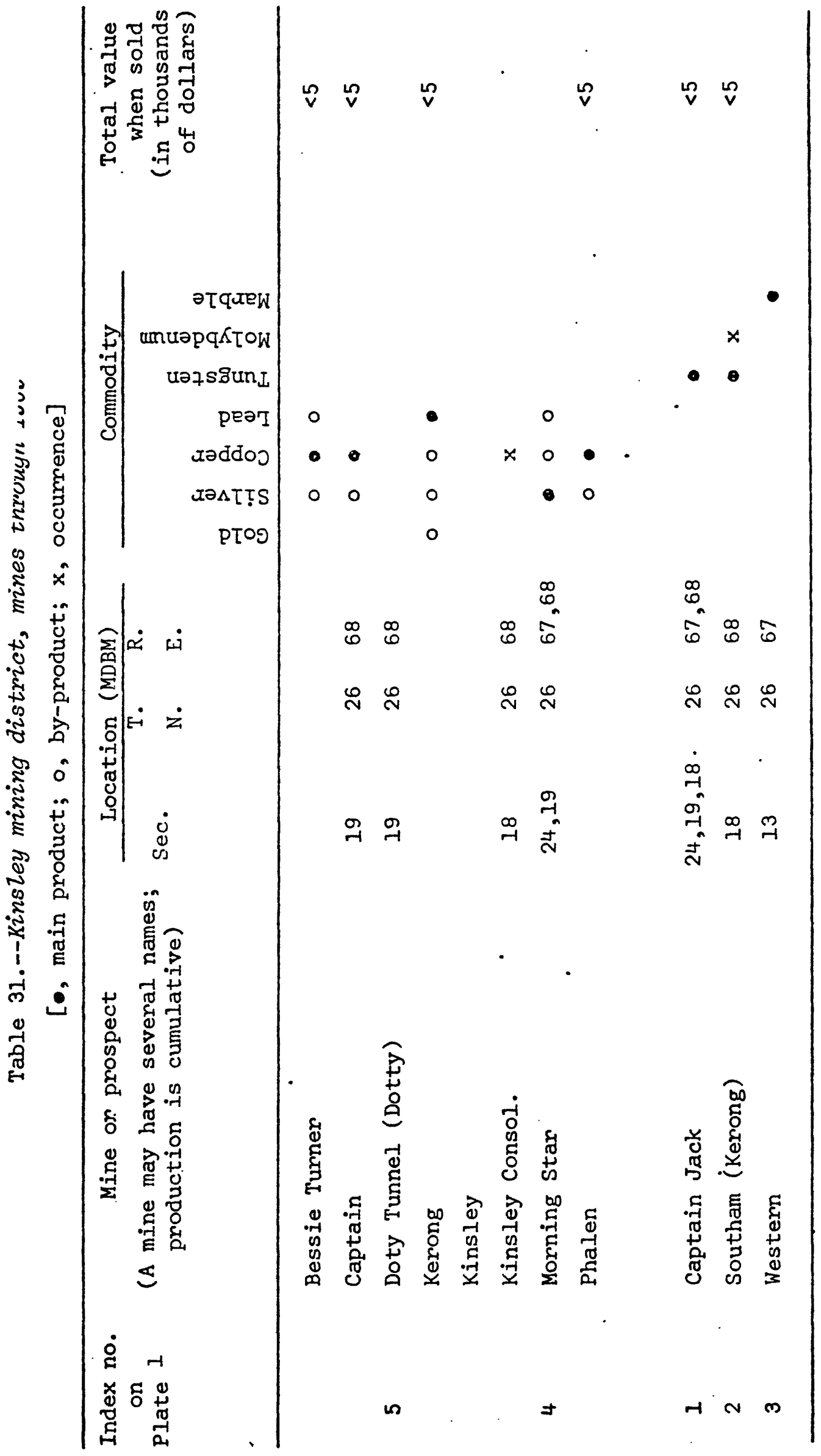


Average grade of all the lead-copper-silver production recorded was about 1.24 oz silver per ton, 3.7 percent copper, and 8.1 percent lead, but the records do not include ore proziced before 1886. About 20 tons of ore produced from the Morning Stam mine dump in 1913 contained $28.7 \mathrm{oz}$ silver per ton, 8.5 percent lead, and 3.42 percent copper (Hill, 1916, p. 92). Grade of the sorted tun $\equiv s: e n$ ores ranged from 0.8 to 30 Eercent $\mathrm{WO}_{3}$.

Lafayette district

Location and history

\begin{tabular}{llll}
\hline $\begin{array}{l}\text { Sections } \\
\text { (Approx.) }\end{array}$ & $\begin{array}{l}\text { T. } \\
\text { N. }\end{array}$ & $\begin{array}{l}\text { R. } \\
\text { Quadrangle name } \\
\left(7 \frac{1}{2} \text { or } 15 \text { minute }\right)\end{array}$ \\
\hline $5,6,7,8$ & 35 & 64 & Snow hater Lake NE \\
\hline
\end{tabular}

The Lafayette district incluies the lower southeast slopes of the Wood Hills about 5 miles northeast of Iobar (Granger and others, 1957, P. 104). There is no record of production from the district.

\section{Geologic setting and ore deposits}

Near the south end of the Wood Hills, marbleized limestones of Cambrian and Ordovician ages overlain by Eureka quartzite (Ordovician) crop out across the full width of the range. Along the southeast slopes they are overlain by dolomitic limestones cf Ordovician, Silurian, and Devonian ages in the upper plate of a thrust fault. The Lafayette district covers part of the upper plate limestones.

The mineral deposits explored in secs. 6 and 7 are narrow veins along faults. In sec. 6 the north shaft $20 \mathrm{ft}$ deep inclined $45^{\circ} \mathrm{NE}$. in limestone exposed a quartz vein as much as $3 \mathrm{ft}$ wide containing malachite, azurite, and limonite. In sec. 7 the 30 -foot shaft inclined $600 \mathrm{iH}$. in liriestone exposes a fault breccia इbout $4 \mathrm{ft}$ wide containing marifosite, calcite, and iron oxides.

Larrabee district

Location and history

\begin{tabular}{lllll}
\hline $\begin{array}{l}\text { Sections } \\
\text { (Approx.) }\end{array}$ & $\begin{array}{l}\text { T. } \\
\text { N. }\end{array}$ & $\begin{array}{l}\text { R. } \\
\text { E. }\end{array}$ & $\begin{array}{l}\text { Quadrangle name } \\
\left(7 \frac{1}{2} \text { or } 15 \text { minute) }\right.\end{array}$ & . \\
\hline All & 28 & 53 & $\begin{array}{c}\text { Pine Valley, Robinson } \\
\text { Mountain }\end{array}$ & $\begin{array}{c}\text { See index map at County } \\
\text { Recorder's office }\end{array}$ \\
\hline
\end{tabular}

The district includes the drainage area of Pony Creek on the west slope of the Sulfur Spring Range north of Coffin Mountain.

A prospect shaft in sec. 16 and an unnamed barite mine at the common corner of secs. 5, 6, 7, and 8 are the only mines in the district. Small shipments of barite were reported (Horton, 1963, p. 8). 
The unnamed district in T. 28 N., R. 55 E., listed by Lotz (1934, p. 18), may be the Larrabee district.

Lee jistrict

Location and history

\begin{tabular}{lllll}
\hline $\begin{array}{l}\text { Sections } \\
\text { (Approx.) }\end{array}$ & $\begin{array}{l}\text { T. } \\
\text { N. }\end{array}$ & $\begin{array}{l}\text { R. } \\
\text { E. }\end{array}$ & $\begin{array}{l}\text { Quadrangle name } \\
\left(7 \frac{1}{2} \text { or } 15 \text { minute) }\right.\end{array}$ & Other district names \\
\hline $31,32,33$ & 31 & 58 & Lamoille & $\begin{array}{l}\text { Ruby Mountain Range } \\
\text { Ruby Range }\end{array}$ \\
\hline
\end{tabular}

The Lee district includes mines in Long Canyon and Segunda Creek Canyon on the west side of the Ruby Mountains about 10 miles southeast of Lee.

The district was discovered in 1869 and ores containing lead, silver, and copper were shipped during 1871 and 1917-19 from the B.B. and American Beauty mines. Subsequent production is credited in official records to the Ruby Mountain Range district (1923-25) and the Ruby Range district (1947-58), much of it from the knob Hill mine. Total production from the Lee district through 1958 is about 1,400 tons of lead ore containing sore zinc, copper, silver, and a little gold. In this report production before 1920 is indicated in table 5 opposite Lee district and for 1923-58 it is included with "undistributed." No production was reported for 1959 through 1969.

The unnamed district in T. 31 N., R. 57 E., listed by Lotz (1934, p. 18), may be the Lee district.

\section{Geologic setting and ore deposits}

The oldest formation exposed in the Lee district is Prospect Mountiin Quartzite. It is overlain by a thick series of limestones, also of Cambrian age. These formations are intruded by dikes, sills, and irreguiar masses of granite and granite pegmatite, and metamorphosed to quartzbiotite schists, recrystallized limestone, and marble (R. G. Reeves, written commun., 1951).

The ore bodies are quartz-calcite veins as much as $5 \mathrm{ft}$ wide that strike northwest and dip southwest. They contain galena, sphalerite, and locally chalcopyrite, with small amounts of silver and a trace of gold. A shipment in 1949 of sorted ore averaged 29 percent lead and about 2 oz silver per ton. 


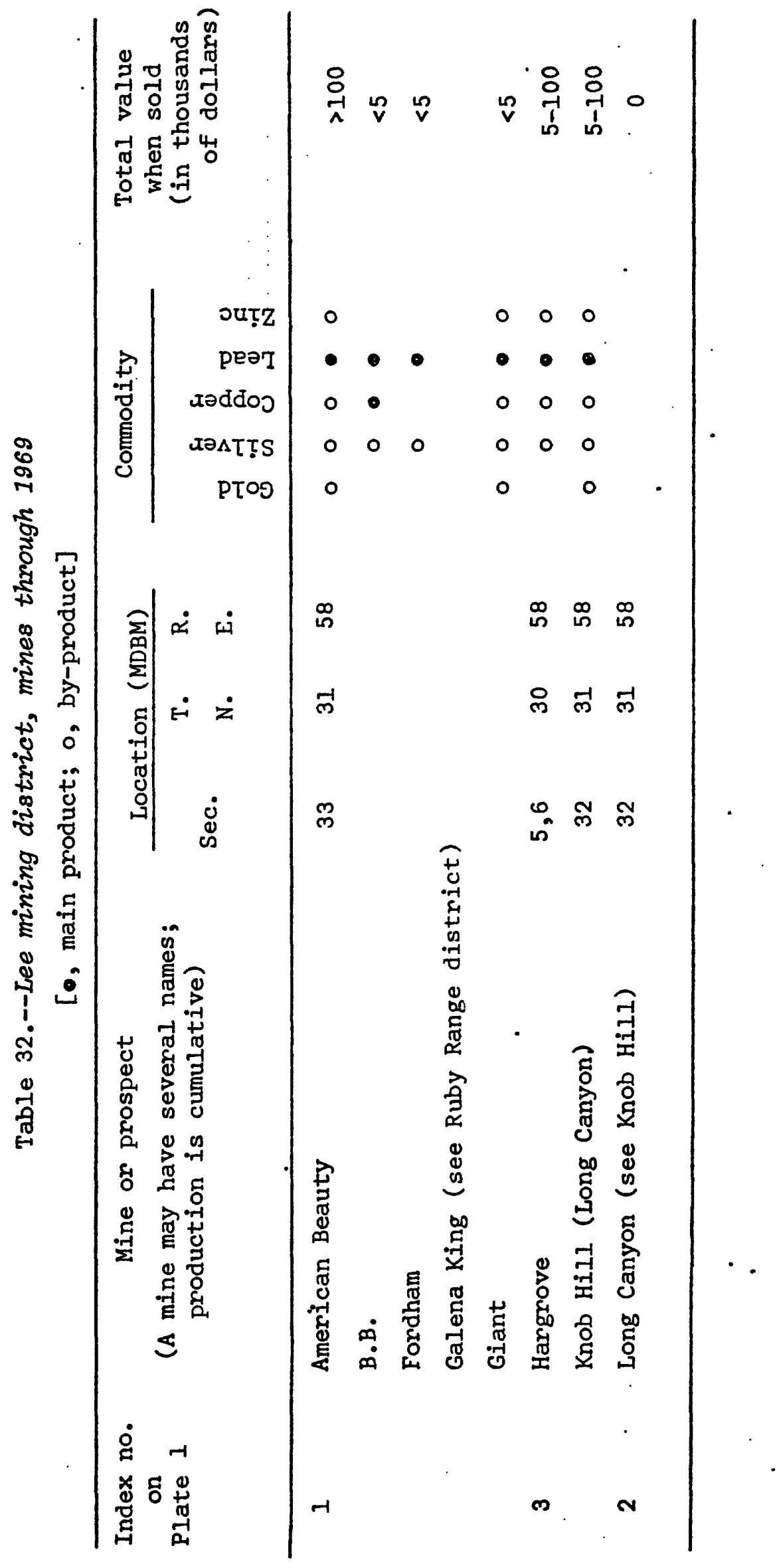


Lime Mountain district

Location and history

\begin{tabular}{lllll}
\hline $\begin{array}{l}\text { Sections } \\
\text { (Approx.) }\end{array}$ & $\begin{array}{l}\text { T. } \\
\text { N. }\end{array}$ & $\begin{array}{l}\text { E. } \\
\text { (7 }\end{array}$ & $\begin{array}{l}\text { Quadrangle name } \\
\text { (15 minute) }\end{array}$ & Other district names \\
\hline 1,12 & 42 & 51 & Bull Run & Independence, Deep Creek \\
6,7 & 42 & 52 & Bull Run & Independence, Deep Creek \\
\hline
\end{tabular}

The Lime Mountain district includes all of Lime Mountain, which extends northward from Deep Creek $1 \frac{1}{2}$ miles and is the southernmost peak of the Bull Run Mountains, formerly named the Centennial Range. The mines and millsite are on the east slope of Lime Mountain.

The district was discovered prior to 1908 (Emmons, 1910, p. 70), but production for the early years, mainly from the Eldorado mine, is not recorded. Intermittent production from 1918 through 1942 exceeds 18,211 tons which contained $8,423 \mathrm{oz}$ of gold, $25,795 \mathrm{oz}$ of silver, 635,156 ib of copper, and 28,319 $1 \mathrm{~b}$ of zinc. About 95 percent of the ore came from the Lime Mountain mine. No production is recorded from the district during the years 1943-69.

\section{Geologic setting and ore deposits}

Lime Mountain consists of sedimentary rocks of the eastern assemblage. Prospect Mountain Quartzite along the lower west slope dips eastward and is overlain by slates and phyllites (Pioche Shale equivalent) about $700 \mathrm{ft}$ thick which are overlain by limestones about 3,200 ft. thick that make up most of the mountain. Immediately to the north these Cambrian strata are concealed, covered by western assemblage cherts and argillites of Carboniferous(?)' age in the upper plate of the Trail Creek thrust fault of Jurassic(?) age. The upper plate--and by inference the underlying concealed lower plate--is intruded by the 2-mile-diameter Wilson plug composed of andesite porphyry of Eocene(?) age; the plug forms the summit and both slopes of the Bull Run Mountains on both sides of Wilson Canyon. East of the range at lower altitudes, both plates are overlain by marl, shale, oil shale, sandstone, conglomerate, chert, and tuff beds about 5,000 ft thick of the Humboldt Formation of Miocene age. On the east side of Lime Mountain, however, lower plate strata are in fault contact with Humboldt beds along a Basin-Range block fault, and on the west side, with Quaternary alluvium along the Owyhee block fault which has a normal dip slip exceeding 4,000 ft (Decker, 1962, pl. 1).

The mines and prospects in the district are on the east slope of Lime Mountain, in Cambrian limestones that are cut by north-trending faults, intruded by dikes of quartz porphyry, andesite, and diabase, and locally metamorphosed to coarse-grained marble. The ore bodies in the Lime Mountain mine are along a fault having postmineral movement. Pyrite, chalcopyrite, bornite, a little silver and gold, and some secondary chalcocite are intergrown with white and black mica, calcite, and quartz (Emmons, 1910, p. 71). 


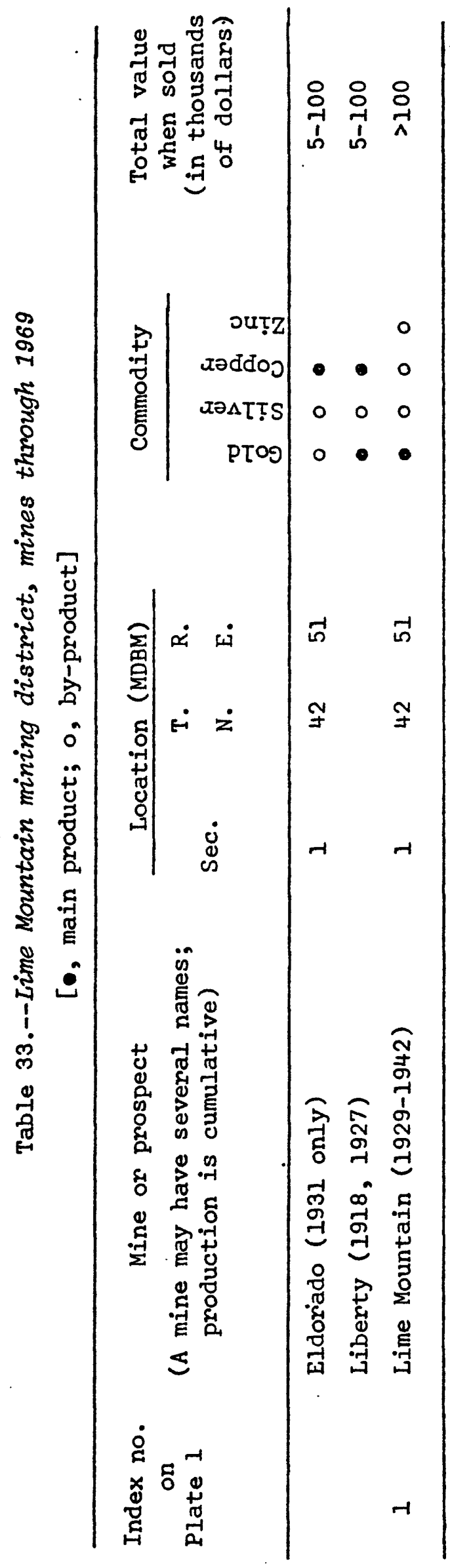


Loray district

Location and history

\begin{tabular}{|c|c|c|c|c|}
\hline $\begin{array}{l}\text { Sections } \\
\text { (Approx.) }\end{array}$ & $\begin{array}{l}\mathrm{T} \\
\mathrm{N}\end{array}$ & $\begin{array}{l}\text { R. } \\
E \text {. }\end{array}$ & $\begin{array}{l}\text { Quadrangle name } \\
\text { ( } 7 \frac{1}{2} \text { or } 15 \text { minute) }\end{array}$ & Other district names, remaris \\
\hline $34,35,36$ & 38 & 67 & Loray & Cobrecite mine \\
\hline$S-1 / 6$ & 38 & 68 & Loray, Pilot Peak NW & Luray, Leroy, Montello, Cobr $\equiv$ \\
\hline $\mathrm{N}^{1} \frac{1}{2}$ & 37 & 68 & $\begin{array}{l}\text { Cobre SE, Pilot } \\
\text { Peak NW }\end{array}$ & $\begin{array}{l}\text { Luray, Leroy, Montello, Cobre, } \\
\text { Castle Park }\end{array}$ \\
\hline
\end{tabular}

The Loray district covers the north end of the Toano Range south of Jora: and east of Cobre, which are stations on the Southern Pacific Railroad $\equiv \equiv \ldots$ miles southwest of Montello, and west of Castle Park well (pl. 1).

Copper-lead deposits of the Silver Star group were known in 1913 (Hill, 1916, p. 96), and intermittent production was reported from seven mines (table 34) for the years 1917-21, 1934-46, and 1954-58. Product: $0:=$ figures in table 5 are less than those reported by Granger and others ( $1 \equiv:$, p. 106) which included production from other districts. Volcanic ash (pumicite) was mined from three open cuts at the Cobrecite mine during ti: 1940 's(?). Foundations of a sizing and bagging(?) plant still remain $3 \equiv \equiv=$-: mine. A few tons may have been produced.

\section{Geologic setting and ore deposits}

The north end of the Toano Range is composed of the normal eastern assemblage of sedimentary strata, mainly limestones, ranging in age frorr. Cambrian through the Pennsylvanian Grandeur Formation. The strata are t: $=: e c$ generally about $30^{\circ}$ W., are intruded by a stock (T. $36 \mathrm{~N} .$, R. 68 E., beti: Loray and Proctor) about 3 miles long of granodiorite of Jurassic age, an: are cut by many faults, most of which strike either northward or eastwer:. On the west side of the range these Paleozoic formations are overlain $y$ y younger sedimentary rocks, mainly tuffaceous sandstone, of Tertiary age. In the area of the Cobrecite mine (pl. 1), a deposit of very light gray, friable pumicite (rhyolite vitric tuff) $100 \mathrm{ft}$ or more thick strikes noritwest and dips about $10^{\circ} \mathrm{NE}$. A stratum about $20 \mathrm{ft}$ thick that was mined consists almost entirely of slightly compacted but uncemented 50- to 325-mesh particles of rhyolite glass.

The metallic ore bodies are white opaline quartz veins along faulis in nearly white crystalline limestone of the Pogonip(?) Formation of Ordovic:an age. Pods and veinlets of chrysocolla and copper pitch, malachite, azur:-e, carbonates of lead and zinc, and residual sulfides occur with limonite in anc along the quartz veins. Grade of the ores shipped ranged from. 0.5 to $900 z$ silver per ton, 0-9 percent copper, 0-9 percent lead, and 0-9 percent zins. 


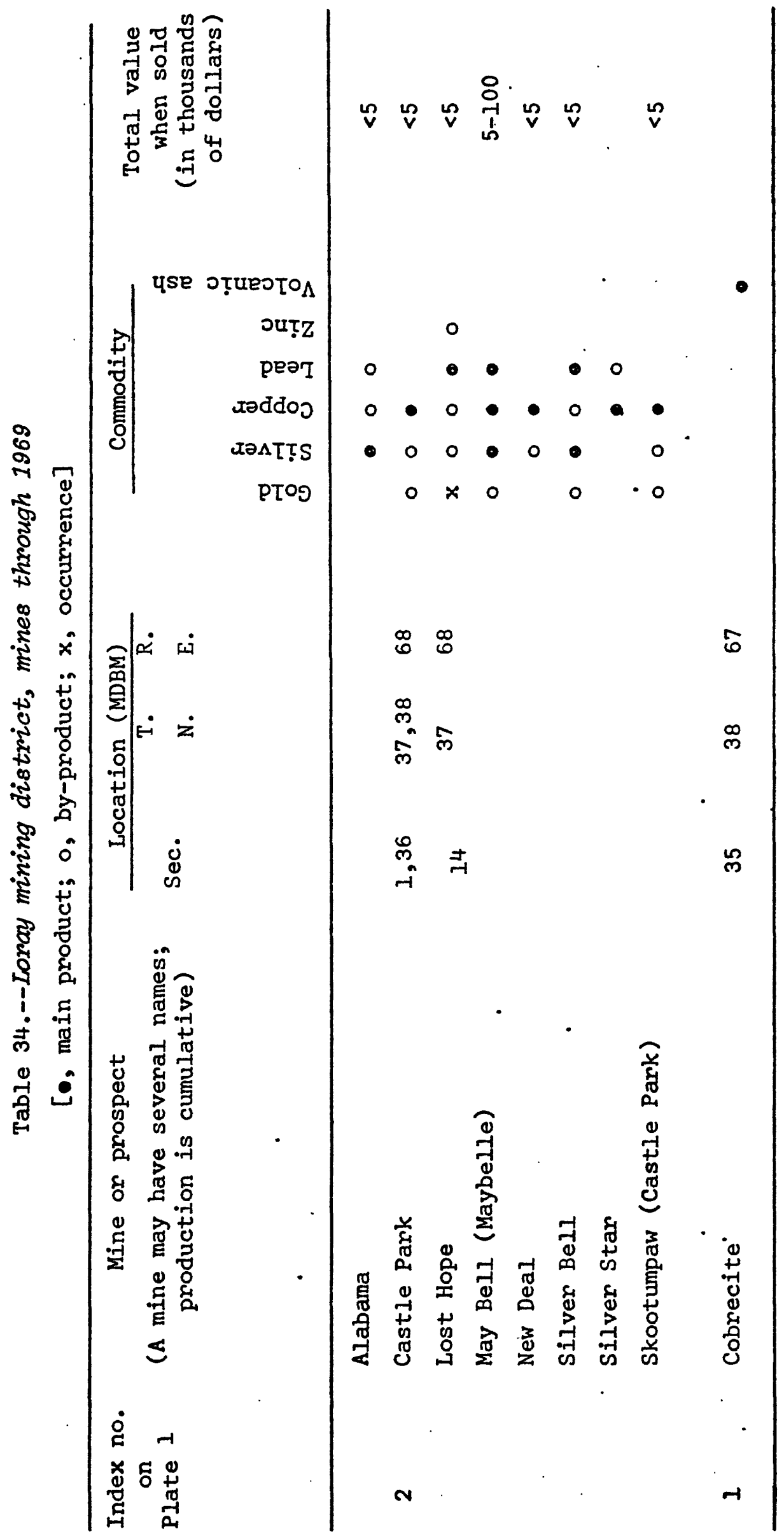


Lucin district

Location and history

\begin{tabular}{|c|c|c|c|c|}
\hline $\begin{array}{l}\text { Sections } \\
\text { (Approx.) }\end{array}$ & $\begin{array}{l}\mathrm{T} \\
\mathrm{N}\end{array}$ & $\begin{array}{l}\text { R. } \\
E \text {. }\end{array}$ & $\begin{array}{l}\text { Quadrangle name } \\
\text { ( } 7 \frac{1}{2} \text { or } 15 \text { minute) }\end{array}$ & Remarks \\
\hline All & 39 & 70 & Tecoma, Patterson Pass & Elko County, Nev. \\
\hline All & $7 *$ & $19 \mathrm{~W} . *$ & Tecoma, Lucin & Box Elder County, Utah \\
\hline All & $6 *$ & $19 \mathrm{W.*}$ & Tecoma, Patterson Pass & Box Elder County, Utah \\
\hline
\end{tabular}

The Lucin or Buell district covers the north end of the Pilot Range south of Tecoma, Nev., and Lucin, Utah, both of which are stations on the Southern Pacific Railroad. Most of the mines are in Utah, either on Copper Mountain near the crest of the range or on Tecoma Hill on the west flank near. the state line. Part of the Tecoma mine property extends westward into Elko County.

Copper ores were discovered on Copper Mountain in 1871 and lead-silver ores on Tecoma Hill shortly thereafter. A 20-tpd lead-smelting furnace was built at Buel City in Elko County in 1871 and was operated until 1875 or 1876. The copper deposits were worked between 1886 and 1894. An aerial tram was built from the Copper Mountain mine to the west base of the range at Tuttle in 1900, where a rail spur constructed in 1906 connected with the main Union Pacific line at Tecoma. Copper- and lead-silver production reached a maximum in 1917, then declined to intermittent shipments of a few tons or a few hundred tons. Limonitic iron ores containing a little copper, lead, and silver were shipped in 1910, 1913, and 1920 for use as smelter flux, and again in 1930-31 to a California paint company. More than 2,000 tons of oxidized zinc ores were mined intermittently since 1917. The aeri玉1 tram and lead smelter were sold for scrap in 1941. About 9,000 tons of limonite ore from Copper Mountain was shipped to the Atomic Energy Commission at Richland, Wash., in 1953.

Total production from the district through 1917 was estimated (Butler and others, 1920, p. 489 ) to be 152,495 tons containing $104 \mathrm{oz}$ gold, 225,136 oz silver, $16,577,321 \mathrm{lb}$ copper, $.4,749,122 \mathrm{lb}$ lead, and $34,680 \mathrm{lb}$ zinc valued at $\$ 3,256,193$. Figures for much of the production since 1917 have not been published, but the district total through 1966 may exceed $\$ 3.5$ million.

Production was credited to the Nevada part of the district (tables 5 and 35) for the years 1874, 1916, 1925, 1935, 1953, 1965, and 1966.

Exploration and development for open-pit zinc mining were reported in 1961 (Southem Pacific Co., 1964, p. 111). 


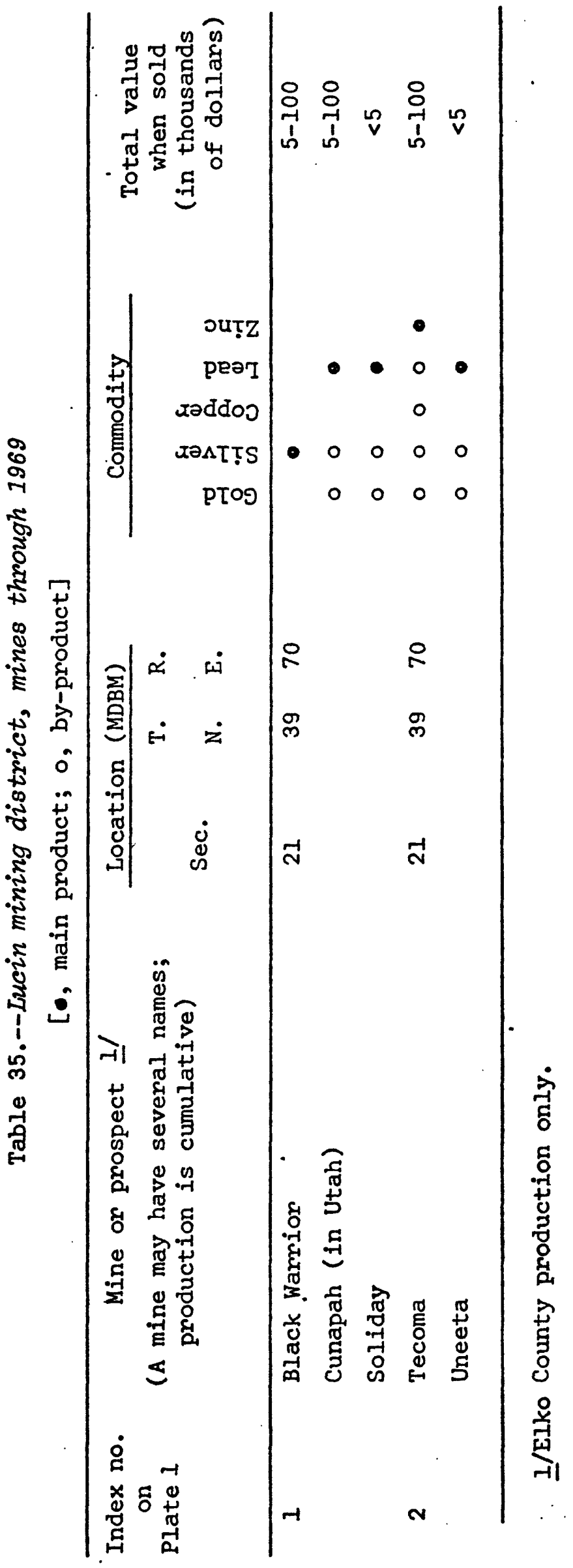


Geologic setting and ore deposits

The geology of the Utah part of the district has been described by V. C. Heikes (Butlen and others, 1920, p. 488-494) and by D. M. Blue (i960). Sedimentary formations of the eastern assemblage from the Eureka Quartzite upward through limestones of the Pequop Formation are tilted about $30^{\circ} \mathrm{E}$., complexly faulted, and intruded by the Patterson Pass monzonite-quartz monzonite (locally porphyritic) stock about 8 miles long north-south and as much as $3 \frac{1}{2}$ miles wide. The sedimentary rocks are intruded also by dikes of aplite and diabase; dikes of quartz diorite intrude both the stock and the sedimentary rocks. Veins of coarse quartz containing sulfides occupy the same fissures as many of the aplite dikes.

On the north side of Tecoma Hill, east of Buell, dolomite and linestone strata are intruded by another small stock of quartz monzonite ajout half a mile across. Along the borders of the stocks the limestones are locally metamorphosed to lime silicate minerals. Contact metamorpic deposits of copper(?) have been prospected but were not mined.

In the Elko County part of the district the only eastern assembiaze rocks that crop out are the Fish Haven, Laketown, and Simonson Dolomites. They are in fault contact with limestones, shales, sandstones, and co:glomerates of the Salt Lake Formation of Miocene-Pliocene age which, at the northern end of the range, form the west foothills.

Most of the copper and iron ores were mined from ore bodies alon north-striking fractures of the Copper Mountain fault zone about 1,002 It wide where it cuts massive limestone strata 850-900 ft thick which f: :the basal member of the Guilmette Formation. The largest copper deposits occur as replacements of favorable limestone beds adjacent to the fractines.

The lead-silver-zinc ores in the area of Tecoma Hill are veins along faults that strike east or northeast and dip steeply southward, irregular replacement bodies in favorable limestone beds adjacent to the veins, and pipelike replacement deposits at their intersections with north-striking fractures. They are restricted to the lower limestone member of the Guilmette Formation and the Laketown and Fish Haven Dolomites.

Ore minerals in the copper and iron deposits on Copper Mountain include malachite, azurite, chrysocolla, cuprite, tenorite, copper-stained clay minerals, native copper, goethite, limonite, and hematite.

Ore minerals in the lead-silver-zinc deposits in the Tecoma Hill area include anglesite, "cerussite, smithsonite, hemimorphite, plumbojarosite, unidentified silver minerals, native silver, and a little native gold, residual galena, sphalerite, and chalcopyrite. Gangue minerals include calcite, clay minerals, and iron oxides. In the lower parts of the ore bodies, wulfenite was abundant.

Hague and Emmons (1877, p. 498) reported: "The molybdate of lead frequently forms so high a percentage of the lead ore as to interfere seriously with its treatment in the ordinary lead furnaces $* * *$. The crystallized wulfenite from the Tecoma mine occurs in large masses, the 
faces of individual crystals having been observed from an inch to $1 \frac{1}{2}$ inches in length." The source of the molybdenum is not known; descriptions

$\therefore$ of the stocks do not mention molybdenite.

Average grade of the copper ores for a few selected years ranged from 5 to 8 percent copper, limonite ores contained about 44 percent iron, some lead-silver ores shipped in the early.years contained 45 percent lead and $35 \mathrm{oz}$ silver per ton, and oxidized zinc ores contained 7-18 percent zinc.

The ores of the Lucin district, especially those on Copper Mountain, were almost completely oxidized. They were also shallow, mostly less than $60 \mathrm{ft}$; explorations below depths of about 200 failed to find ore. This type of occurrence suggests that they may be localized in the upper plate of a thrust fault, although thrust faults have not as yet been positively identified.

Merrimac district

Location and history

\begin{tabular}{|c|c|c|c|c|c|}
\hline $\begin{array}{l}\text { Sections } \\
\text { (Approx.) }\end{array}$ & $\begin{array}{l}\text { T. } \\
\text { N. }\end{array}$ & $\begin{array}{l}\text { R. } \\
\text { E. }\end{array}$ & $\begin{array}{l}\text { Quadrangle name } \\
\text { ( } 7 \frac{1}{2} \text { or } 15 \text { minute) }\end{array}$ & & Other district names \\
\hline$S \frac{1}{2}$ & 38 & 53 & McDermitt, Wells & & Lone Mountain \\
\hline All & 37 & 53 & Blue Basin, Singletree. & Creek & Grand Junction(?) \\
\hline
\end{tabular}

The Merrimac district includes all of Lone Mountain, a conspicuous ridge in the Independence Mountains west of Dinner Station on Nevada Highway 11, 24 miles north of Elko. In reports of the Fortieth Parallel Survey the mountain was called Nannies Peak, and this name is retained for the northernmost peak of the ridge. Land office records listed under Merrimac district include a South Merrimac claim.

$\therefore \quad$ Copper-lead-silver deposits were discovered in 1866, and the Lone Mountain district was organized in 1869 or 1870. About 1,000 tons of ore was produced through 1907. Granite, quarried about 30 miles north of Elko during 1907-13 for use in the town, probably came from this district. Part of the metal production during 1912-18 and all of it since 1924 are recorded under the Merrimac district. Most of the production from 1918 through 1954 was lead-zinc-silver ore from the Rip Van Winkle mine.

A barite deposit was explored prior to 1959. . Molybdenite with pyrite in silicified rock was reported (Schilling 1962a, p. 14) to occur on Fox Creek Ranch near Dinner Station. Tungsten was produced at the Lone Wolf and Open Pit (Lone Mountain) mines prior to 1963 (Schilling, 1963a). Turquoise was reported (Morrissey, 1968, p. 5) from the Carlin Black Matrix mine, but the mine could not be located during a field check in 1965.

No production was recorded from the district for the years 1966 through 1969. 


\section{Geologic setting and ore deposits}

The oldest rocks exposed in the Merrimac district are sandstones, calcareous siltstones, cherts, and shales of Ordovician and Silurian ages (western facies), fault slices of which are in thrust-fault contact with and overlie limestones of Devonian and older Devonian(?) age (eastern facies). The older Devonian(?) Iimestone is invaded by five successive intrusives, each of a different composition and all of Tertiary age. Oldest of these intrusives is a stock $1 !_{2}$ miles long north-south of biotite quartz latite exposed on the lower east flank of Lone Mountain, followed by a stock 2 miles long and a mile wide of diorite higher up the slope. The limestone is intruded by a dikelike body of quartz monzonite porphyny 3 miles long, one-third of a mile wide, dipping $70^{\circ} \mathrm{W}$, called the Nanries Peak intrusive, exposed along the west slope and the ridge top. The limestone and the two older stocks at their south ends are intruded by $a$ third stock of quartz monzonite 1.7 miles long, which is itself intrudei by dikes of quartz porphyry as much as a mile long and 1,000 ft wide tiat trend northward and dip eastward. Small lenses of conglomerate locall; overlie the rocks of the western Eacies and are overlain by welded tuf a few thousand(?) feet thick that mantle the foothills on the north, west, and south sides of Lone Mountain; vitric tuffs and alluvium floor the desert valley on the east side (Lovejoy, 1959).

The ore bodies are veins along faults, replacement deposits in marbleized limestone, and contact metamorphic deposits in garnetized l:-aestone.

Vein deposits at the Rip Van Ninkle mine (Lovering and Stoll, 1943) are localized along a segment of a north-striking reverse fault that dips steeply west in cherty shales and shaly limestones (western assemblage) near their contact with granite porphyry and is bounded by steep eastdipping mineralized normal faults. The vein is more than $4 \mathrm{ft}$ wide in places and was mined or explored for $600 \mathrm{ft}$ along the strike to the 600 level. One of the east-dipping faults was explored to the 700 level (Granger and others, 1957, pl. 12, 13). Branch veins and bedded replacement bodies near the veins were also mined. The veins are stepfaulted a few feet along some of the east-dipping faults.

The primary ore minerals are sphalerite, chalcopyrite, and galena with some silver, and gold, in a gangue of quartz, altered wallrock, and pyrite, but most of the ore mined consisted of their oxidation products. Much of the ore averaged about 2 percent lead, 1.5 percent $z$ inc, 0.1 percent copper, and $7.5 \mathrm{oz}$ silver per ton. Total recorded production of these metals from the district averaged about $\$ 19$ per ton.

Replacement deposits along the bedding in marbleized limestone near the veins contain a higher proportion of zinc than the veins.

Contact metamorphic deposits are localized in the gamet-actinolite zones. They contain pyrite, chalcopyrite, arsenopyrite, and locally scheelite, magnetite, and a little copper carbonate. 


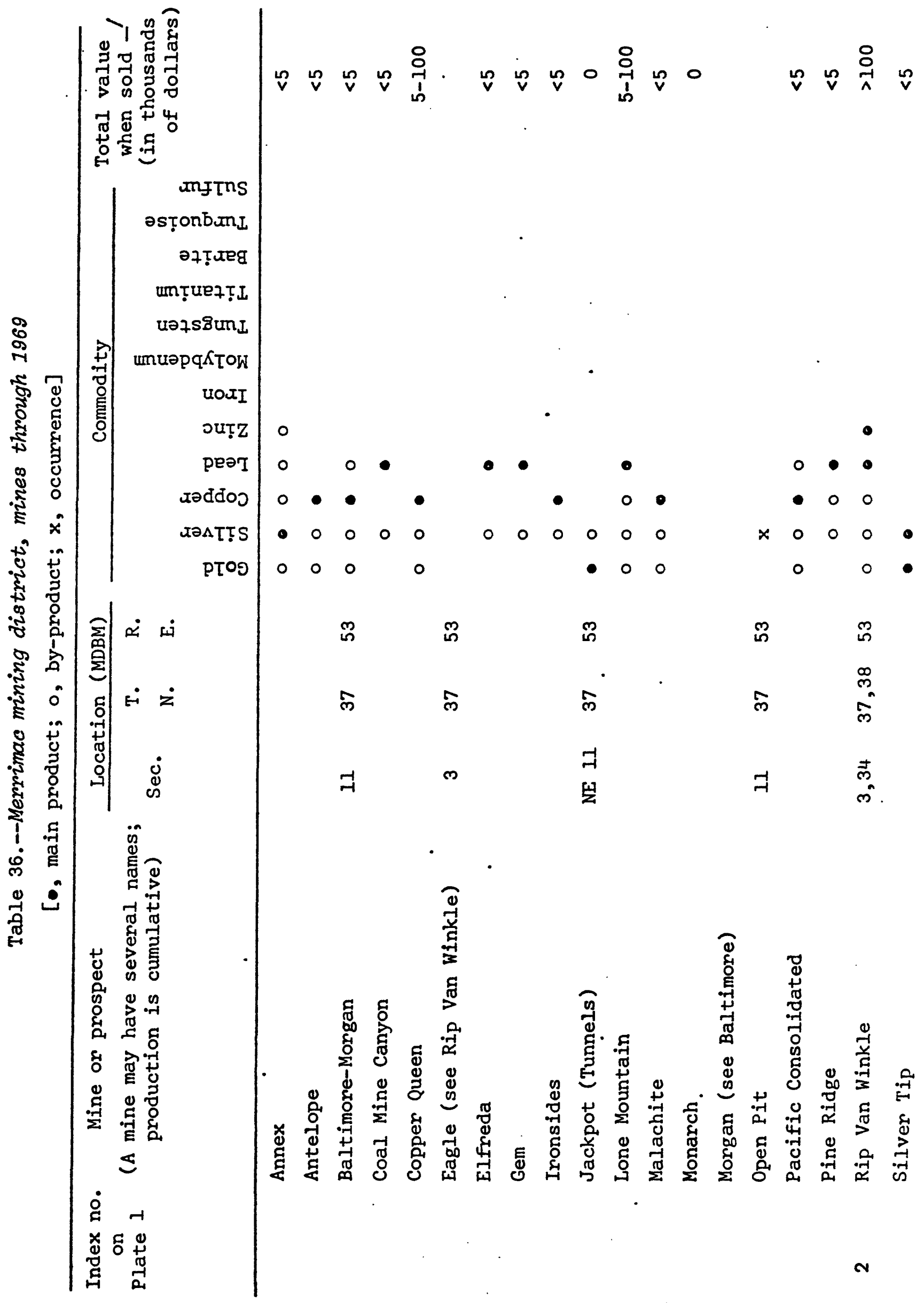




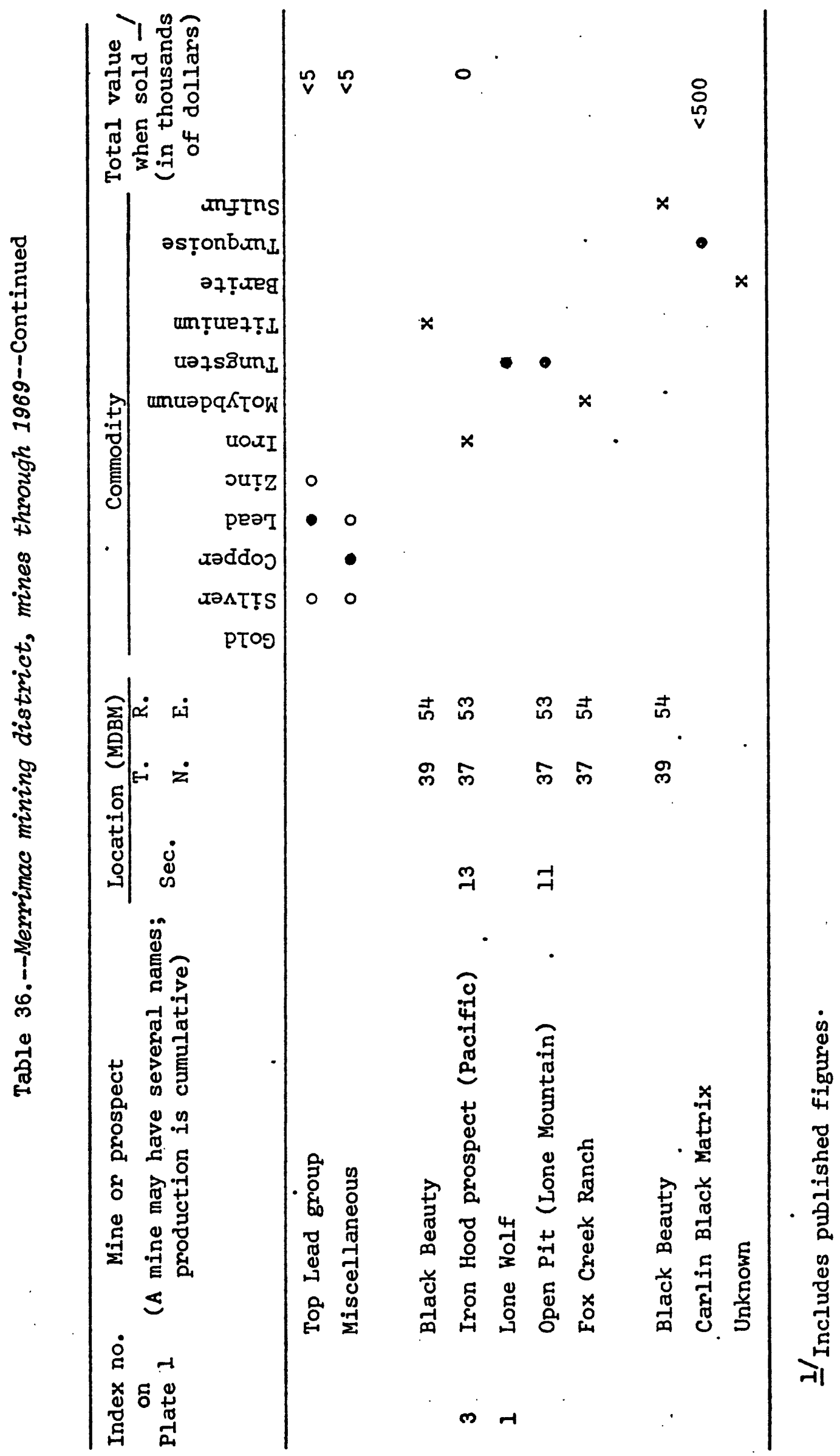


A few miles north of the Merrimac district, sulfur has been reported to occur with minor amounts of pyrite and ilmenite $\left(1-1 \frac{1}{4}\right.$ percent $\left.\mathrm{TiO}_{2}\right)$ in black slates and shale on the west side of Gonce (Ganz?) Creek (Beal, 1963, p. 15). The sulfur is probably a surface alteration product of weathered pyrite.

Montello phosphate area

Location and history

\begin{tabular}{llll}
\hline $\begin{array}{l}\text { Sections } \\
\text { (Approx.) }\end{array}$ & $\begin{array}{l}\text { T. } \\
\text { N. }\end{array}$ & $\begin{array}{l}\text { E. } \\
\text { E. }\end{array}$ & $\begin{array}{l}\text { Quadrangle name } \\
\left(7 \frac{1}{2} \text { or } 15 \text { minute) }\right.\end{array}$ \\
\hline $\mathrm{SE}^{\frac{1}{4}}$ & 39 & 67 & Valley Pass, Loray \\
$\mathrm{SW} \frac{1}{4}$ & 39 & 68 & Loray \\
$1,2,3,4$ & 38 & 67 & Valley Pass, Loray \\
$W^{\frac{1}{2}}$ & 38 & 68 & Loray
\end{tabular}

The Montello phosphate area is along the crest and lower east slopes of Murdock Mountain south of Montello Canyon, north of Loray, and 5-1l miles west of Montello. The southern part of the area overlaps the north side of the Loray mining district.

Prospecting permits 065997, 067058, and 067059 from the Conservation Division, U.S. Geological Survey, were in effect from December 1, 1965 to - August 31, 1972. Exploration by trenching and drilling exposed faulted segments of phospnatic shale in five or more localities. The thickest interval sampled was $14 \mathrm{ft}$ that assayed 15.77 percent $\mathrm{P}_{2} \mathrm{O}_{5}$. The highest grade found was 20.5 percent $\mathrm{P}_{2} \mathrm{O}_{5}$ across $5.5 \mathrm{ft}$. No production has been reported as of mid-1973.

The geologic setting of the Meade Peak Member of the Phosphoria Formation is summarized under Pequop phosphate area.

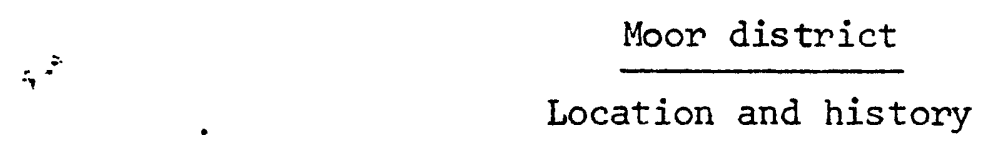

Sections T. R. Quadrangle name

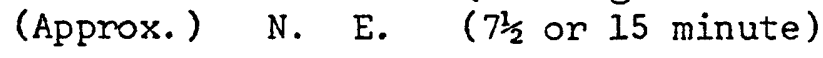

\begin{tabular}{llll}
\hline All & 37 & 63 & Moor Summit \\
All & 37 & 64 & Moor Summit \\
\hline
\end{tabular}

The Moor district covers the north end of the Wood Hills south of Moor Summit and the north end of Independence Valley south of Highway U.S. 40.

A test lot of 500 tons of limestone for use in sugar refining was quarried prior to 1964 from beds $3-8 \mathrm{ft}$ thick in the SW/4 sec. 7, T. $37 \mathrm{~N}$., R. $64 \mathrm{E}$. The 1 imestone analyzed 97.18 percent $\mathrm{CaCO}_{3}, 1.2$ percent $\mathrm{MgCO}_{3}$, 1.35 percent $\mathrm{SiO}_{2}, 0.13$ percent $\mathrm{Fe}_{2} \mathrm{O}_{3}$, and 0.02 percent $\mathrm{Al}_{2} \mathrm{O}_{3}$ (Southern Pacific Co., 1964, p. 128). 
Deposits of decorative marble in secs. 13 and 21, T. 37 N., R. 63 E., deposits of silica in the $S \frac{1}{2}$ of the same township, and a lead prospect in sec. 13 were also reported by the Southern Pacific Co. (1964, p. 129, 137, $\therefore 94)$.

The most recent work, about 1971, in the area was exploratory drilling, presumably of a thrust fault, near the lead prospect a mile southwest of Moor siding.

\section{Geologic setting and ore deposits}

The north end of the Wood Hills consists of sedimentary strata, predominantly dolomites and limestones, ranging in age from Cambrian to Pennsylvanian and Permian(?) that are folded along northeast-trending axes and displaced along thrust faults in two localities, one near Moor Sumit and the other in the west foothills 3-6 miles southeast of Wells. On the lower west slopes these eastern assemblage formations are overlain by sedimentary strata of Tertiary age; one outcrop of bedded chert and argillite is mapped as "western facies(?)."

Dumps at the "Mines" shown on the map of the Moor. Sumit quadrangle near Moor Summit are of shattered limestone cemented by many small calcite veinlets. Some of the dump rock may have been used for aggregate. Near Wadel Spring prospect shafts 5-10 ft deep explored quartz veins as much as a foot wide along the bedding in gently dipping limestone. Malachite, azurite, chalcocite, and iron oxides occur sparsely in the quartz.

The lead prospect in sec. 13, T. 37 N., R. 63 E., was explored for a length of $85 \mathrm{ft}$ and a depth of $30 \mathrm{ft}$. Galena occurs in stringers and pods in an oxidized zone $\frac{1}{2}-3 \frac{1}{2}$ ft wide that strikes N. $70^{\circ} \mathrm{E}$. and dips $30^{\circ}-60^{\circ} \mathrm{S}$. in brecciated limestone.

Iron prospects in sec. $24, \mathrm{~T} .37 \mathrm{~N} ., \mathrm{R} .63 \mathrm{E}$. were explored by several trenches, pits, and adits. Gossans to $6 \mathrm{ft}$ wide strike northeast for several humdred feet and dip steeply in calcareous mylonite (Southern Pacific Co., 1964, p. 93).

$$
\text { . } \frac{\text { Mountain City district }}{\text { Location and history }}
$$

\begin{tabular}{|c|c|c|c|}
\hline $\begin{array}{l}\text { Sections } \\
\text { (Approx.) }\end{array}$ & $\begin{array}{ll}\text { T. } & \text { R. } \\
\text { N. } & \text { E. }\end{array}$ & $\begin{array}{l}\text { Quadrangle name } \\
\left(7 \frac{1}{2} \text { or } 15 \text { minute }\right.\end{array}$ & $\begin{array}{c}\text { Other district names, } \\
\text { remarks }\end{array}$ \\
\hline
\end{tabular}

$25,26,35,36 \quad 4653$ Mountain City Murray(?), Cope, Duck

Valley Indian Reservation

All 4654 Mountain City. Fairweather, Sooner

All 4553 Owyhee, Mountain City Cope, Marseilles (sec. 21), Van Duzer (S. I/3), Rio Tinto

$\begin{array}{lllll}\text { All } & 45 & 54 & \text { Mountain City } & \text { Cope, Van Duzer (secs. 30, 31) } \\ 1,2,3 & 44 & 53 & \text { Wild Horse } & \text { Van Duzer }\end{array}$


The Mountain City district extends from Van Duzer Creek and the Wild Horse Range on the south to Winter Ridge (Pin Mountain?) on the north, and from the headwaters of Mill Creek on the west to Rough Mountain and Merritt Mountain on the east. It includes the following older districts:

Cope - California Creek (lode and placer), Hansen Gulch (placer), Grasshopper Gulch (lode and placer), and Mill Creek (Rio Tinto lode mine)

Murray - $" * * *$ in the northwest comer of the county, Cope joins it on the southeast." (White 1871, p. 61)

Sooner - "*** formerly known as Fairweather *** about ten miles east of Mountain City, in the Bruneau range ***." (Thompson and West, 1881, p. 395)

Marseilles (Mountain Laurel patent) - sec. 21, T. 45 N., R. 53 E.

. Van Duzer - placers on Van Duzer and Cobb Creeks

Land Office records are listed under Cope and Van Duzer districts.

Silver-gold lode deposits were discovered in 1869 in the Cope, Murray, and Fairweather districts. Those in the Cope district led to the founding of Mountain City and to a silver rush in 1870 when the new town grew to a population of about 1,000. Over $\$ 1,000,000$ in silver was produced prior to 1881 (Granger and others, 1957, p. 114). Gold placers discovered in 1893 in the Van Duzer district were worked intermittently (Emmons, 1910, p. 84) -and yielded about $\$ 150,000$.

The district is best known, however, for the Rio Tinto Copper mine and the gratifying story of its discovery.1/ The mine produced $\$ 21$ million,

$1^{\prime}$

"In 1919 he (S. F. Hunt) was attracted to the area by an extensive. gossan outcrop. He located the ground and a short time after succeeded in interesting V. P. Strange, local contractor, in the prospect. In 1922 Mr. Hunt started development of the property on a small scale and the work continued until 1930 when his backers were forced to give up the project. At this time a shaft was down 73 feet.

"His stoic determination and faith in the property was manifested when he continued to seek funds and finally made a deal with Ogden $C$. Chase, local broker, to continue development of the property. Mr. Chase agreed to furnish $\$ 50,000$ for the work, but when the ore was struck only $\$ 7,000$ had been spent.

"The depression worked a hardship upon Mr. Chase and he had difficulty in raising the funds, so he instituted a new and unique method of financing. Mr. Chase gave the stock away with the agreement that stockholders would pay 5 cents per share in assessments. The fifth assessment had been levied when the ore was encountered and the stock has since advanced to around 20 cents a share." (Western Mineral Survey and Utah Statesman, v. 13, no. 30, July 22,1932 .) 
making Mountain City the leading district in the county. From its discovery in 1931 until the mine closed in 1947, the Rio Tinto deposit yielded $1 ; 109,878$ tons of ore averaging 9.7 percent copper, 0.3 oz of silver, and $0.006 \mathrm{oz}$ of gold per ton. Of the $216,326,000 \mathrm{lb}$ of copper produced, $92,460,238$ ib was recovered from 177,043 tons of ore averaging 26.1 percent copper shipped directly to the Garfield (A.S.ER. Co.) and Tooele (I.S. \& R.Co.) smelters in Utah. The remaining 932,835 tons of ore averaging 6.6 percent copper was concentrated at the mine (Coats and Stephens, 1968, p. 1077) and the concentrate shipped to the Tooele smelter. During much of its life the mine yielded the highest grade copper ore produced in the United States.

Manganese ore was produced from the wicker mine in 1943.

Tungsten ores were produced from the Golden Ensign mine during the $1950^{\prime}$ 's(?), but the major production was silver-gold ore.

Uranium was discovered in 1954, and by 1959 eleven or more prospects had been found, three of which resulted in commercial production (table 37 ). As of 1963, the largest uranium producer in the county was the Racetrack mine which yielded nearly 10,000 ib of $\mathrm{U}_{3} \mathrm{O}_{8}$ (Schilling, 1963b). Exploration for uranium in the California Basin area was still in progress in 1971.

During 1970-71, development was in progress to prepare unmined portions of the Rio Tinto deposit for extraction. The mining plan was to partly remove the Footwall ore body to permit block caving and to leach the broken ore in place through drill holes from the surface. Production was expected to be 4.8 million pounds of copper per year.

\section{Geologic setting}

The oldest rocks exposed in the Mountain City area are two members of the Valmy Formation of Ordovician age. A lower siliceous member, possibly more than 10,000 ft thick, consisting of cherts and greenstone with at least two interbedded quartzite units and one phyllite unit, is overlain by an upper argillaceous member more than 1,100 ft thick, composed of black and gray well-bedded phyllite. The phyllite of the upper member, locally termed "Rio Tinto shale," is subdivided into five units based on color which are readily distinguishable underground but not on the surface. The lowest unit, a black phyllite (schistose shale) with chert layers near the base, is more than $100 \mathrm{ft}$ thick; the second is thin altemating layers of gray and black well-bedded phyllite (Footwall shale) 450-710 ft thick; and the middle unit, which is the host rock of the Rio Tinto lode, is a black carbonaceous shale 130-250 ft thick. The fourth unit is a well-bedded black phyllite (Hanging wall black shale) 110-250 ft thick; and the uppermost unit is a limy, gray, well-bedded phyllitic shale more than 370 ft thick.

South of the Mountain City area about 4 miles, bluish-gray limestone with argillaceous members and thin quartzite lenses is in thrust fault contact with and underlies the Valmy Formation. It is part of the "Eastern assemblage" of predominantly carbonate strata. 


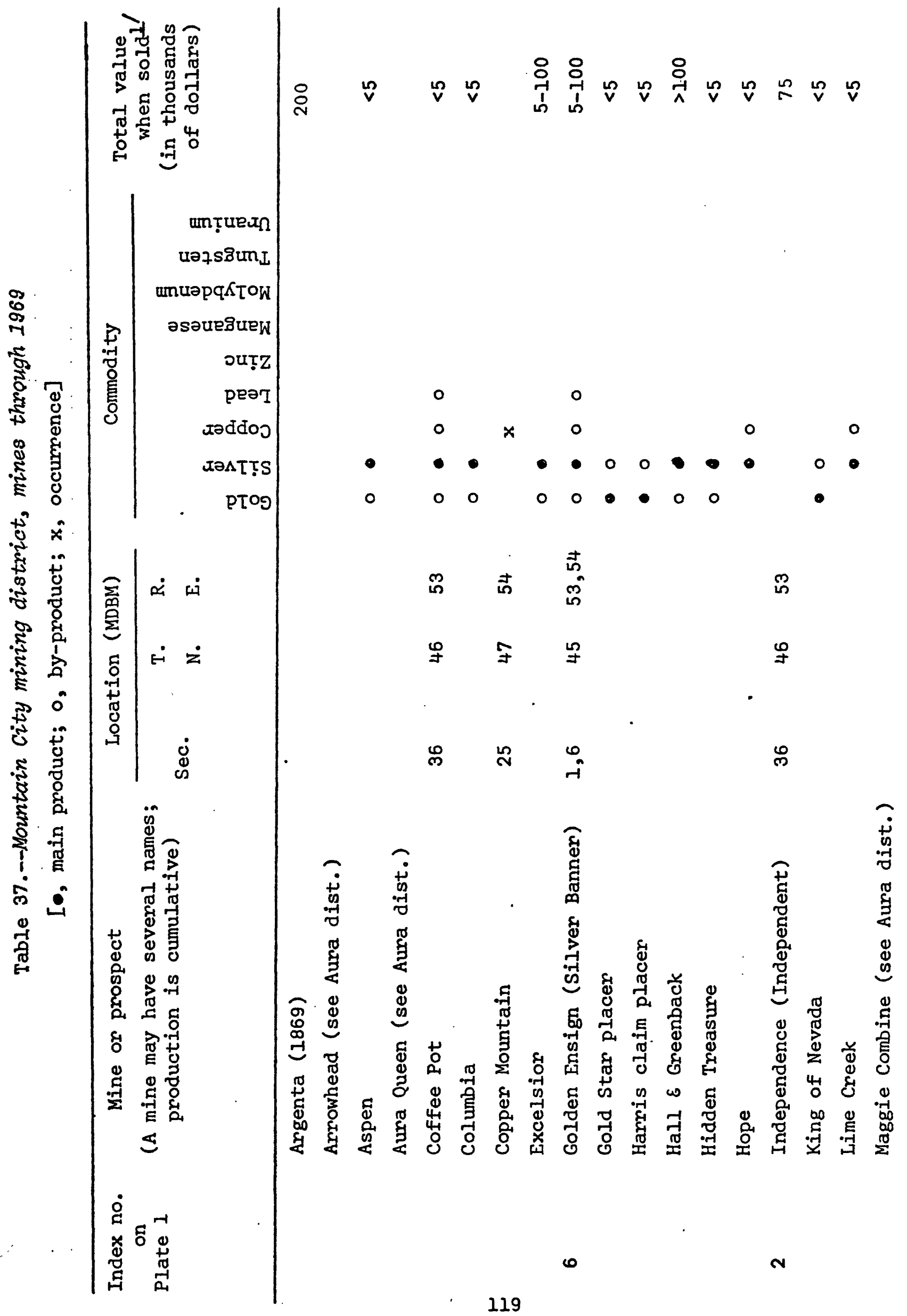




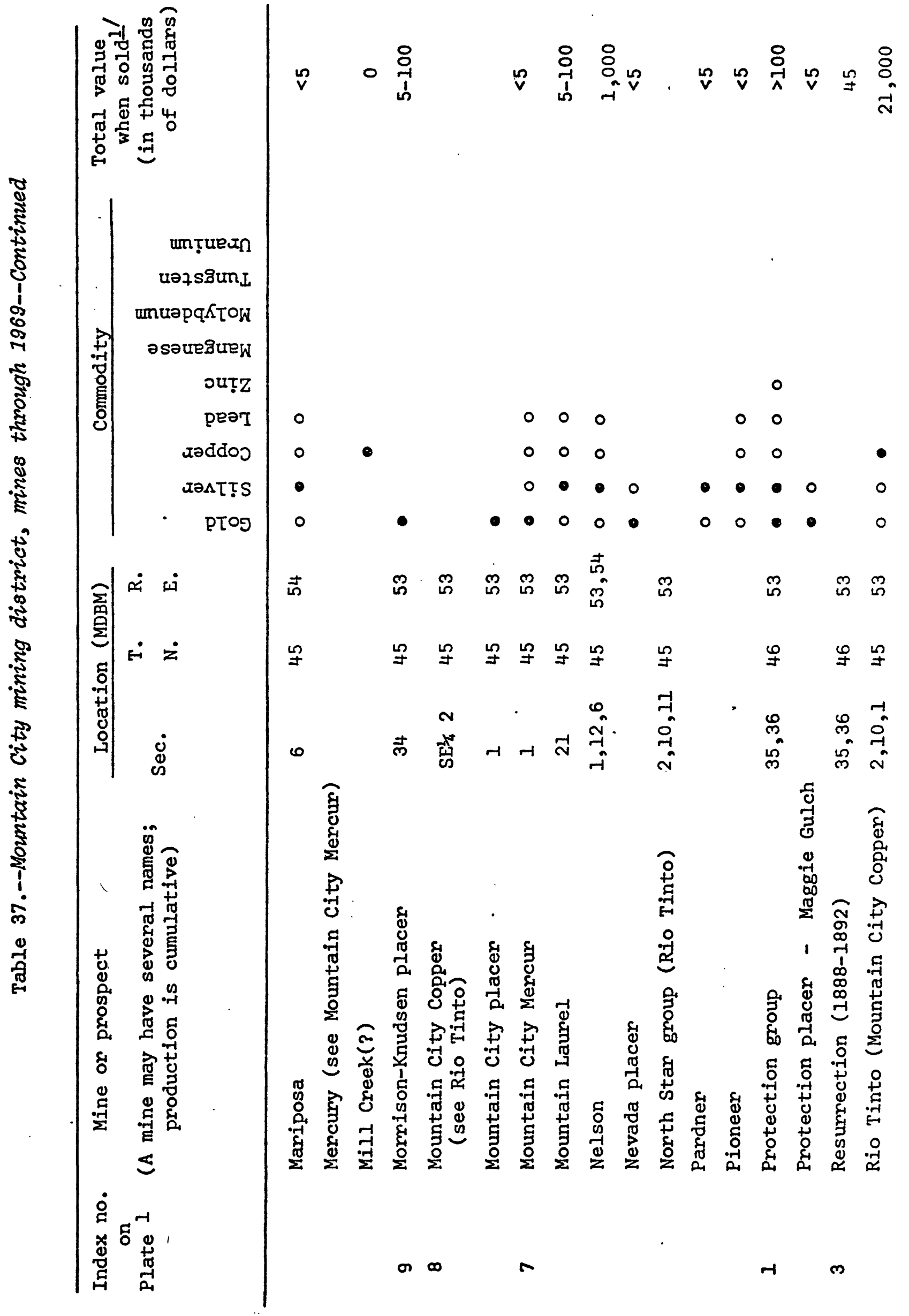




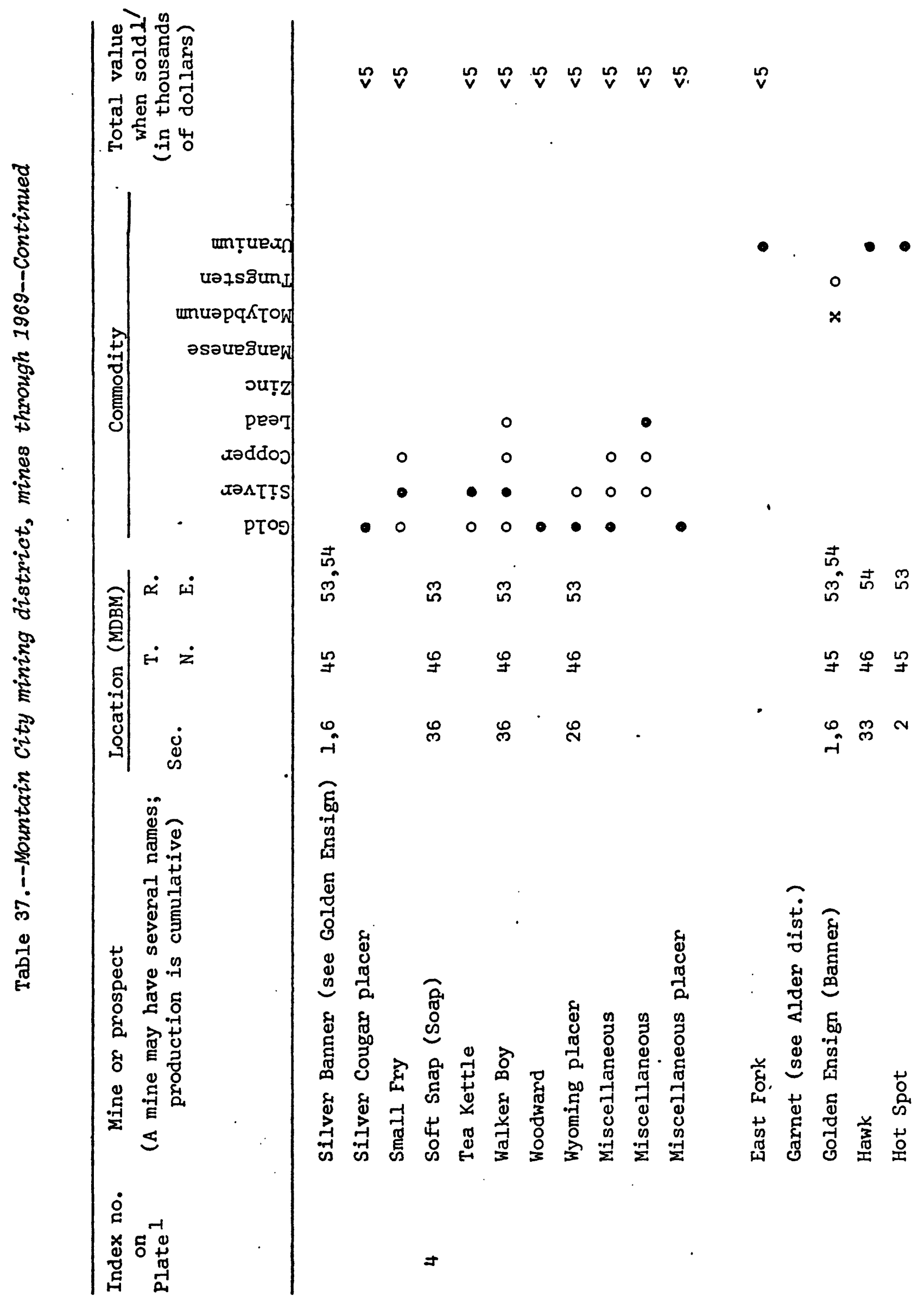




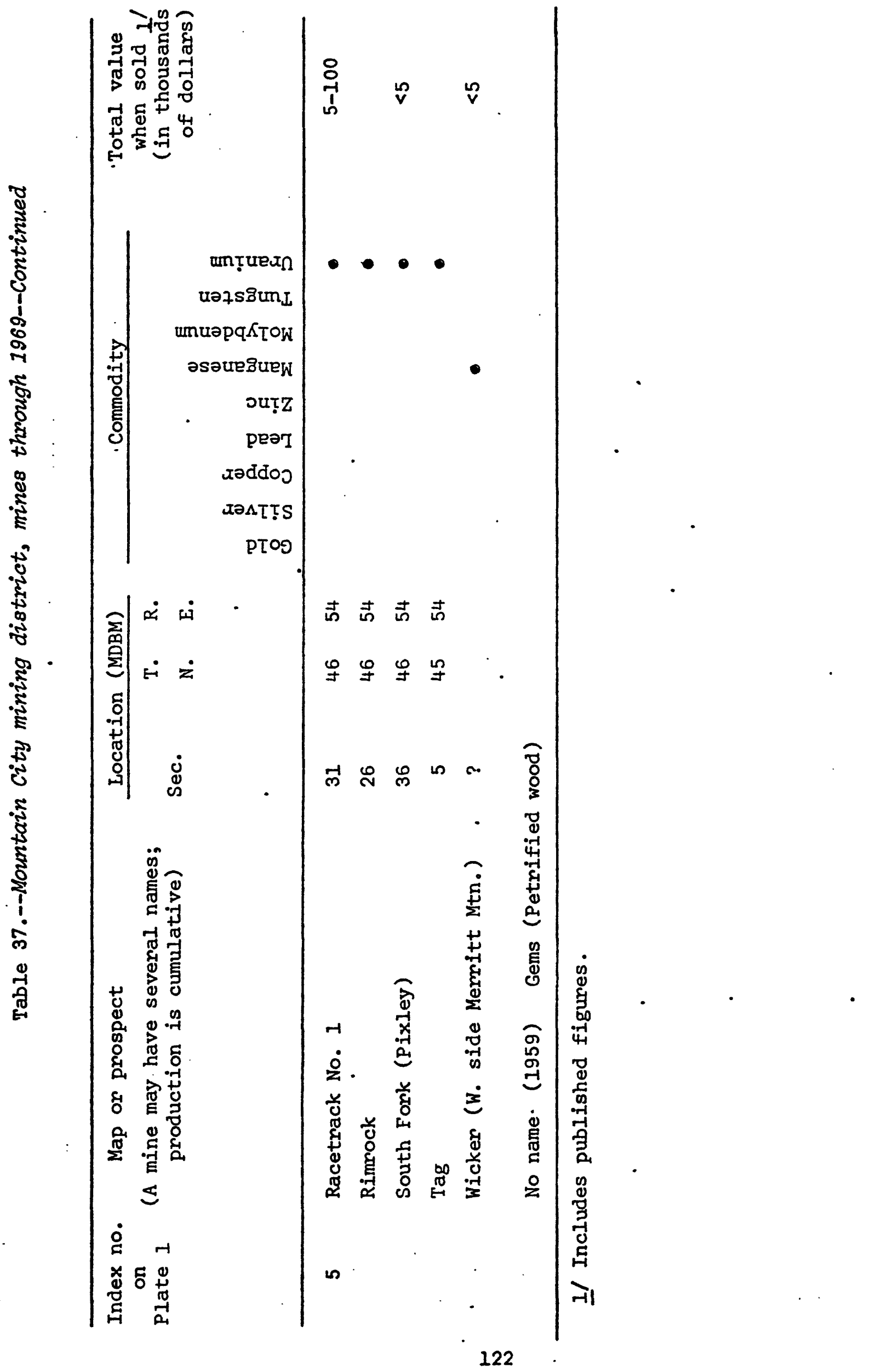


Overlying the Valmy unconformably are five other Paleozoic formations which may total 15,000 ft thick--Grossman conglomerate, Banner limestone, Nelson metavolcanics (amphibolites), Mountain City graphitic phyllite and

$\therefore$ other rocks, and the Reservation Hill siltstone and other rocks.

The Paleozoic formations are intruded by a stock of quartz monzonite, as much as 12 miles across, of late Cretaceous age. Unconformably overlying the stock and the Paleozoic formations are erosional remnants of four mutually unconformable volcanic formations and an interlayered mudflow, all of Tertiary age, which may total about $700 \mathrm{ft}$ thick.

In parts of the Owyhee River valley the Paleozoic rocks are overlain by gold-bearing quartzite gravels of Quaternary age that occupy terraces at three different altitudes. These gravels are noteworthy for their coarseness--boulders as large as $17 \mathrm{ft--and} \mathrm{evidently} \mathrm{were} \mathrm{transported} \mathrm{by}$ the Tertiary mudflow and reworked by the Owyhee River.

The Paleozoic formations are tilted moderately to steeply northward, and are cut by faults of at least three different ages. Many steep normil faults and a few local thrust faults that trend northwest and have relative? $\because$ large horizontal components of displacement are older than the quartz monzonite. They may be.contemporaneous with the Roberts Mountains thrust fault of early Mississippian(?) age which is inferred to underlie the area at a depth of about 5,000 ft. Also older than the stock is an easttrending bedding fault along the middle unit of the Rio Tinto shale.

- Cutting the quartz monzonite and all older rocks are steep normal faults that strike in various directions and have vertical displacements of not more than a few hundred feet. Some of these faults contain silver-goldbearing quartz veins. Later normal faults that trend northward to eastwan: and dip generally northwest displace the Rio Tinto ore body as much as $130 \mathrm{ft}$ horizontally and the Tertiary volcanics $400 \mathrm{ft}$ or more vertically.

\section{Ore deposits}

The mineral deposits are of eight different mineralogic types, manganess, copper, tungsten, molybdenum, gold, silver-gold, uranium, and placer gold. Each type resulted from different combinations of ore controls and range in age from Paleozoic to Holocene. All types except molybdenum have been commercially productive.

Manganese deposits

oldest of the eight types is a bedded deposit of rhodonite, rhodochrosite, and bementite. Several carloads of ore were shipped from the Wicker mine during 1943. The ore shipped contained about 40 percent manganese and was classed as high silica.

\section{Rio Tinto copper deposit}

The Rio Tinto mine contains the only large deposit of high grade, predominantly copper-bearing ore in the district. The geologic setting of the Rio Tinto deposit is also unique. 
The main Rio Tinto deposit is a tabular lode along a bedding-plane shear zone $150 \mathrm{ft}$ wide that strikes eastward and dips $65^{\circ}-85^{\circ} \mathrm{N}$. in black carbonaceous phyllitic shale of the middle unit of the upper member of the

$\therefore$ Valmy Formation. The lode contains both primary and secondary (supergene) copper minerals. The primary minerals are later in age than the Nelson Formation (Upper Mississippian) and apparently earlier than the quartz monzonite (Late Cretaceous). Coats and Stephens (1968, p. 1098) infer from inconclusive evidence that they may be related genetically to late Paleozoic mafic vulcanism, later than the Roberts Mountains thrust fault. Secondary enrichment, however, is or early Tertiary and Holocene ages.

A subsidiary deposit in the footwall of the lode contains only secondary oxide and sulfide copper minerals derived from the weathered portion of the lode.

At the surface (altitude $6,100 \mathrm{ft}$ ) and to a depth of about $200 \mathrm{ft}$, the Rio Tinto lode is represented only by a leached gossan. The surface exposure is about $400 \mathrm{ft}$ long and $100 \mathrm{ft}$ wide, but at the 200 level (altitude 5,880 ft), the gossan is more than 1,000 ft long and 40-80 ft wide. Below the gossan and above the water table at about $230 \mathrm{ft}$ a thin discontinuous layer of oxide copper minerals was locally minable. Below the water table massive high-grade secondary copper sulfides in the chalcocite zone extend downward to a depth of $330 \mathrm{ft}$ interlayered with increasing thicknesses of massive primary ore. Below the massive secondary ore, various mixtures of secondary and primary sulfides were found in irregular

- ground-water channels to depths of $430 \mathrm{ft}$, below which only primary sulfides occur.

The lode is displaced by postmineral faults both along and across its strike. Breccia and gouge of those along the strike obscure the channel ways through which the ore-forming solutions were introduced. Northwestdipping normal faults across the strike offset the ore body, cutting it into four main segments and several minor ones that rake down to the west. The greatest horizontal displacement is $130 \mathrm{ft}$ along the easternmost (No. 1) fault which separates the lode into two ore bodies, one above and the other below the fault. This fault also helped to localize the subsidiary supergene. ore body in the footwall of the lode.

Three principal ore bodies yielded nearly all of the ore mined. Two of them, the 200 and the 600, named for the mine levels where they were discovered, comprise two series of faulted segments of the main lode separated by the No. I fault. The third or Footwall ore body is the secondary deposit in the footwall of the lode mentioned above.

The 200 ore body yielded over half the ore. It was about 1,200 ft long, as much as $92 \mathrm{ft}$ wide, and extended $300 \mathrm{ft}$ down the dip from the 200 level to the No. I fault. Four nearly contiguous segments were stoped to assay walls for I, $060 \mathrm{ft}$ along the strike and as much as $80 \mathrm{ft}$ wide between the 200 and 500 levels. The largest segment was unbroken for $500 \mathrm{ft}$ along the 200 level. The 200 ore body contained both primary and secondary (supergene) ore minerals. 
The primary minerals in the ore are predominantly quartz, pyrite, and chalcopyrite. A little galena was found in one locality and sphalerite occurs sparsely throughout. Grade of the primary ore rarely exceeded 10 percent copper and is estimated to have averaged between 6 and 7 percent before being enriched by secondary sulfides.

Oxide copper minerals are concentrated at the top of the 200 ore body in a blanket layer 6 inches to $20 \mathrm{ft}$ thick immediately above the water table where malachite, azurite, cuprite, native copper, and residual chalcopyrite constituted shipping ore in only one place. From this layer to the surface the oxide zone, including the surface gossan, is almost completely leached of copper minerals, and contains a porous mass of quartz, iron oxides, and seams of yellow-brown mud with only occasional specks of malachite, azurite, and cuprite. Below the oxide zone a little native copper was found as deep as the 400 level.

Secondary ore in the 200 ore body was in part massive and high grade, especially at the east end along and near its hanging wall. Much of the ore was bluish black in color, without metallic luster, and contained about 35 percent chalcocite, 35 percent chalcopyrite, 5 percent covellite, 1-5 percent oxide copper minerals, and 20-24 percent gangue, most of which was quartz, although gangue minerals were not evident in hand samples (Smith, A. M., 1932b, p. 5). The largest shoot of massive secondary ore was as much as $240 \mathrm{ft}$ long, $75 \mathrm{ft}$ wide, and extended $150 \mathrm{ft}$ down the dip from the 200 level. Other parts of the ore body were interlayered masses - or lenses of pyrite, chalcopyrite, and quartz partly replaced by chalcocite, bornite, and covellite. Grade of the massive secondary ore ranged from 25-55 percent copper.

The 600 ore body was stoped $300 \mathrm{ft}$ along the strike between the 450 and 650 levels. It was explored down the dip to the 1000 level (altitude $5,077 \mathrm{ft}$ ) below which only two small lenses persist. The 600 ore body contained only primary sulfides similar in mineralogy and grade to the primary ore in the 200 ore body.

$\therefore$ Along the mineralized zone below and west of the 600 ore body, quartz, pyrite, and sphalerite persist for $2,500 \mathrm{ft}$ intermittently along the 700 and 1000 lévels.

The third or Footwall ore body is localized in the Footwall shale and the upper part of the underlying schistose shale south of the east end of the lode partly above but mostly below the No. 1 fault. It extends virtually at right angles from the lode southward for $700 \mathrm{ft}$ attaining a width of $300 \mathrm{ft}$ and a thickness of about $230 \mathrm{ft}$ between depths below the surface of 220 and $450 \mathrm{ft}$. It is estimated to contain more than 600,000 tons, less than a third of which was mined. It contains only disseminated secondary copper minerals derived from the leached and eroded portions of the main lode and transported into the footwall. Elsewhere along the main lode, secondary solutions were confined within it by impervious clay alteration and gouge instead of being disseminated into the wallrock. In the upper part of the Footwall ore body, cuprite, native copper, malachite, and azurite predominate, whereas in the lower part chalcocite is more abundant. These secondary copper minerals replace metamorphic pyrite 
which is disseminated throughout the phyllite, or they fill small openings in the rock. Chalcocite occurs also in rods of dark-gray quartz which are common in the Footwall shales.

$\therefore \quad$ Average grade of the Footwall ore body was about 1 percent copper, but the unmined part may be somewhat lower.

Tungsten deposits

Contact metamorphic deposits of scheelite in tactite occur near the quartz monzonite stock. The only recorded production is from the Golden Ensign mine.

Molybdenum deposits

Molybdenite occurs in quartz veinlets and disseminated in parts of the quartz monzonite. Traces of this mineral are found at the surface in many localities in the Granite Ridge area. Molybdenite also occurs with silver-gold ores of the Golden Ensign mine, and with pyrite in quartz veins or disseminated in quartz monzonite at Huber Hill (Schilling, 1962a, p. 13). There has been no production of molybdenite from the district.

Gold-quartz veins

Gold-bearing pyritic quartz veins are found in the Paleozoic formations and in the quartz monzonite. They are considered to be of Cretaceous age (Roberts and others, 1971, p. 29). These veins are narrow and low grade, and have not been extensively mined or prospected, although they may have contributed gold to the placer deposits.

\section{Silver-gold quartz veins}

Silver-gold-bearing quartz veins occupy faults that cut only the quartz monzonite and older rocks. Rhyolitic tuffs of Tertiary age, however, are hydrothermally altered near some of these veins, suggesting that the mineralization may be any age less than middle Oligocene (Roberts and others, 1971, p. 29). These veins strike in various directions, the most common being northwest. They are brecciated, and many of them are cut off by normal faults both along and across their strikes. In a historical account of the silver mines, Smith (1932a, p. 7) reported: "All the stories end the same way--the vein terminated against a fault $* * *$ at depths of less than 200 feet." Ore shoots in these veins are as much as $5 \mathrm{ft}$ wide, $100 \mathrm{ft}$ long, and subsequently have been mined as deep as about $600 \mathrm{ft}$. The primary ore contains pyrite, galena, sphalerite, tetrahedrite, arsenopynite, chalcopyrite, argentite, and free gold. Nearly all the production, however, has come from oxidized ores which contain cerargyrite, pyromorphite, lead and copper carbonates, chrysocolla, native gold and silver, pyrargyrite, and stephanite. These deposits were the first to be discovered and yielded virtually all the production before 1931. The largest are the Golden Ensign (Silver Banner), Protection, Resurrection, Nelson, and Mountain City. One of them, the Protection deposit, was reopened in 1946 and in a 3-year period produced 2,000 tons averaging about $40 \mathrm{oz}$ of silver and $0.75 \mathrm{oz}$ of gold per ton (Roberts and others, 1971, p. 29). 
Uranium deposits

Uranium deposits occur in Tertiary conglomerates and tuffs only

$\therefore$ where these rocks overlie the eroded surface of the quartz monzonite, which has a background radioactivity count above average, particularly where it is intruded by aplite dikes. The conglomerates are a few inches to several feet thick distributed erratically on the quartz monzonite. The tuffs overlie the conglomerates or rest directly on the quartz monzonite and are a few feet to several hundred feet thick. The uranium deposits are localized along porous or permeable layers generally within the basal 30 feet of the host rocks, although a few lenses are as much as $100 \mathrm{ft}$ above the quartz monzonite. In at least one prospect, uranium minerals are disseminated in weathered quartz monzonite, and in another they are in an aplite dike.

The ore bodies are lenses a few inches to $25 \mathrm{ft}$ thick and as much as $100 \mathrm{ft}$ wide and $200 \mathrm{ft}$ Iong. Lenses of ore grade $\left(0.3\right.$ percent $\mathrm{U}_{3} \mathrm{O}_{8}$ ) as large as 1,400 tons were found during the 1950's.

Ore minerals occur as fillings in cracks and pore spaces in the rocks, or they partly replace fragments of lignitized or opalized wood. The most common ore mineral is autunite, but locally metatyuyamunite, uranophane, or torbernite may predominate. Grade of the deposits is commonly less than 0.25 percent $\mathrm{U}_{3} \mathrm{O}_{8}$ (chemical assay), but a few exceeded 0.3 percent. One mineralized $\mathrm{log}$ assayed 0.5 percent $\mathrm{U}_{3} \mathrm{O}_{8}$.

Placer gold deposits

Small-scale placer mining operations have been carried on intermittently along the Owyhee River, Grasshopper Gulch, and Hansen Gulch; a dredge was operated on Van Duzer Creek and a dragline on Cobb Creek. Placer deposits were worked on both sides of the Owyhee River for several miles north of Mountain City; Grasshopper Gulch was profitably mined for about half a mile; Van Duzer Creek was mined by hydraulic monitor and dredge above the ranch lands for 2 miles; and Cobb Creek, a tributary of Vàn Duzer Creek, was mined for about $1 \frac{1}{2}$ miles starting a mile above Van Duzer Creek.

Largest of the placer deposits was along Van Duzer Creek where the gold-bearing gravel channel was 50-200 ft wide and as much as $15 \mathrm{ft}$ deep. The gold may have been derived in part from the Quaternary terrace gravels and in part directly from quartz veins.

Gold particles range in size from fine dust to nuggets weighing 5 or $6 \mathrm{oz}$ (Emmons, 1910, p. 84). The gold content of gravels worked in 1948 and 1949 was $33 \xi$ and $70 \xi$ per cubic yard. (Johnson, 1973, p. 21). 
Mud Springs district

Location and history

$\therefore$

\begin{tabular}{lllll}
$\begin{array}{l}\text { Sections } \\
\text { (Approx.) }\end{array}$ & $\begin{array}{l}\text { T. } \\
\text { N. }\end{array}$ & $\begin{array}{l}\text { R. } \\
\text { E. }\end{array}$ & Quadrangle name & Other district names \\
\hline All & 28 & 60 & Elko $2^{\circ}$ & $\begin{array}{c}\text { Medicine Springs, Dead Horse, } \\
\text { Butte Valley }\end{array}$
\end{tabular}

The district covers the north end of the Medicine Range in southcentral Elko County between Ruby Valley and Butte Valley. The range is about 12 miles long from north to south, 7 miles wide, and rises steeply from 6,000 ft to the three 9,000-foot High Bald Peaks.

Lead-silver ore was discovered in 1910 and the first shipments were to the United States Smelting and Refining Company smelter at Salt Lake City in 1915. A 100-ton flotation plant was installed in 1929, but only a small tonnage was treated and the plant was dismantled. A 60-ton wet concentrating plant (four tables) was installed in 1950 at Medicine Springs and about 1,300 tons from the Silver Butte mine was milled in 1950 and 1951. A few tons were produced from the Rainbow group in 1953 and the Johnnie 1 and 2 claims in 1956. No further production is recorded through 1969.

The Silver Butte mine, which yielded most of the ore from the district, is developed by a 600-foot vertical shaft and six levels, from the 150- to the 400-foot level that total about 4,000 ft of workings (Granger, 1957, p. 124).

\section{Geologic setting and ore deposits}

The Medicine Range consists mainly of limestones, siltstones, dolomites, and cherts about 6,000 ft thick of Permian age, oldest of which is calcareous siltstone of the Riepetown Formation exposed only on the west side of the range. It is overlain successively by Pequop limestones, Loray silitstones, and the Park City Group (Kaibab limestone, Plympton chertdolomite, Gerster siltstone-limestone-chert). Unconformably overlying these Permian formations in the northern part of the range are interbedded sandstones, chert conglomerates, limestones, and calcareous siltstones of the Thaynes Formation of Triassic age. Thin lake beds of siltstone, sandstone, and limestone, flows of rhyolite ash, and remnants of basalt crop out locally in the Tertiary pediment surrounding the range (Collinson, 1968).

The sedimentary formations are cut by many normal faults that strike north to northeast and dip steeply west or are vertical. Apparent displacement is more than 4,000 ft along the southwest front of the range, but at the north end of the range some major faults barely separate thin Triassic strata. The fault pattern in the Medicine Range resembles that of the upper plate of the Golconda thrust on Battle Mountain in Lander County (Collinson, 1968, p. 39). Between the faults the beds are tilted moderately east forming north-trending ridges capped by beds that resist erosion. 


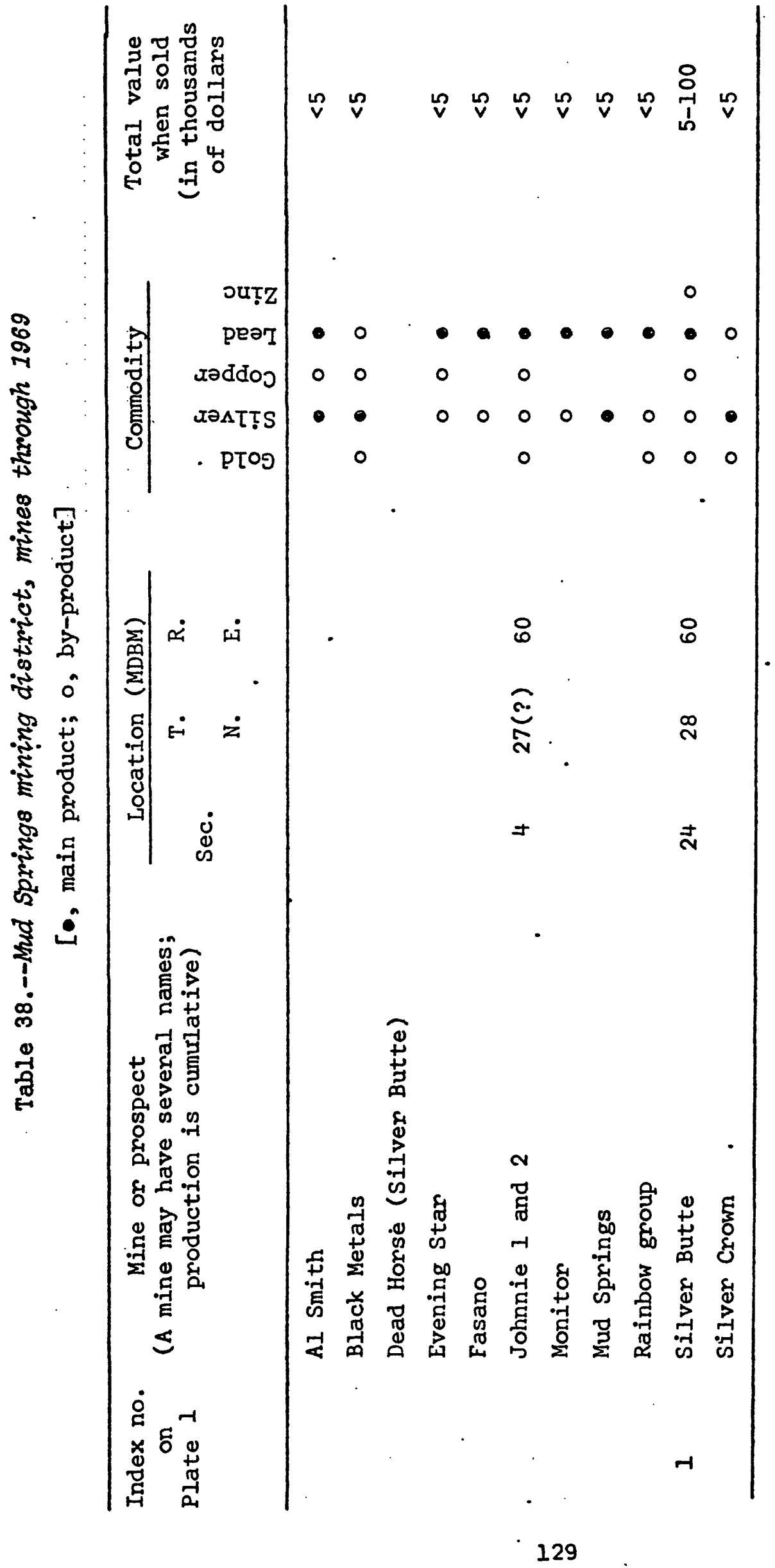


Quartz diorite porphry crops out along or near some of the faults, and fragments of dacite are found on the dump of the Silver Butte mine. The ore deposits are along faults in limestones of the Gerster and Thaynes Formations.

The ore bodies are narrow veins along shear zones as much as $50 \mathrm{ft}$ wide and 2,000 ft long made up of many individual interlacing fault strands. The ore shoots are discontinuous overlapping lenses of vein material as much as $3 \mathrm{ft}$ wide, $60 \mathrm{ft}$ long, and were mined to depths of $400 \mathrm{ft}$ in the Silver Butte mine, where they are localized at intersections of major strands of a fault zone, although not all intersections contain ore.

Gangue minerals are barite with some quartz and calcite. Jasperoid crops out along some of the faults. The main ore mineral is argentiferous galena in veinlets up to 6 inches wide and in isolated pods in the barite. Cerussite, anglesite, and smithsonite with variable amounts of silver occur with the galena on the upper levels (Hill, 1916, p. 65).

Grade of the ore mined averaged about 4.3 percent lead and 4 oz of silver per, ton, but locally the silver content was as high as 40 oz per ton. Concentrates averaged about 55 percent lead and 19 oz silver per ton.

Pequop phosphate area

Location and history

\begin{tabular}{|c|c|c|c|c|}
\hline $\begin{array}{l}\text { Sections } \\
\text { (Approx.) }\end{array}$ & $\begin{array}{l}\text { T. } \\
\text { N. }\end{array}$ & $\begin{array}{l}\text { R. } \\
\text { E. }\end{array}$ & $\begin{array}{l}\text { Quadrangle name } \\
\text { ( } 7 \frac{1}{2} \text { or } 15 \text { minute) }\end{array}$ & Remarks \\
\hline$E^{\frac{1}{2}}$ & 31 & 64 & Spruce Mountain 4 & $\begin{array}{l}\text { Boone Spring, southern } \\
\text { Pequop Mountains }\end{array}$ \\
\hline $\begin{array}{r}\text { A1I } \\
\therefore\end{array}$ & 31 & 65 & Spruce Mountain 4 & $\begin{array}{l}\text { Boone Spring, southern } \\
\text { Pequop Mountains }\end{array}$ \\
\hline$N E \frac{1}{4}$ & 30 & 64 & $\begin{array}{l}\text { Spruce Mountain 4, } \\
\text { Elko } 2^{\circ}\end{array}$ & $\begin{array}{l}\text { Boone Spring, southern } \\
\text { Pequop Mountains }\end{array}$ \\
\hline $\mathrm{NW}^{\frac{1}{4}}$ & 30 & 65 & $\begin{array}{l}\text { Spruce Mountain } 4, \\
\text { Elko } 2^{\circ}\end{array}$ & $\begin{array}{l}\text { Boone Spring, southern } \\
\text { Pequop Mountains }\end{array}$ \\
\hline
\end{tabular}

The Pequop phosphate area includes the south end of the southern Pequop Mountains, east of and adjoining the Spruce Mountain mining district. Phosphorite is exposed in two elongate roughly parallel outcrops about 2 miles apart, one extending about 10 miles along the summit of the range and the other along the lower east slope.

Prospecting permits 064931, 064932, 066342, 067054, 067055, and 067056 from the Conservation Division, U.S. Geological Survey, were in effect from January 1, 1965 to August 31, 1972. Exploration, mostly along the summit of the range, by nine trenches and several drill holes further exposed phosphorite in 15 or more localities. No production has been reported as of mid-1973. 


\section{Geologic setting and ore deposits}

The phosphate deposits in eastern Elko County (see also Montello area, Elko and Coal Mine districts) are in the western fringe of the western phosphate field of Idaho, Montana, Wyoming, and Utah, consisting of interbedded locally phosphatic shale, mudstone, sandstone, chert, and carbonate rock deposited in an ocean basin 1 during the Permian period. Phosphorite occurs in all these strata but is more abundant in the shales. Phosphorite ${ }^{2}$ is not a very distinctive rock. Most phosphorites consist of dark-colored sand-sized phosphatic pellets and nodules up to about $1 \frac{1}{2}$ inches across in a matrix of shale, chert, sandstone, or limy rock. Organic matter, including petroleum, is so common that many deposits are black. Highgrade phosphorite is fairly heavy, and may have a bluish-gray coating (phosphate bloom) on weathered surfaces. The average phosphorite is about 80 percent carbonate-fluor-apatite, 10 percent quartz, 5 percent muscoviteillite, 2 percent organic matter, 1 percent dolomite calcite, 1 percent iron oxide, and I percent other components (Gulbrandsen, 1966, p. 769).

The phosphate mineral in the pellets and nodules is of variable composition. It is basically a carbonate-fluor-apatite of which 3-4 percent is fluorine, and in which uranium, thorium, vanadium, and other metals or nonmetals may substitute for calcium or phosphorus. All phosphorites contain uranium (0.005-0.05 percent), usually in amounts high enough to be detected by gamma-ray well logging and even by airborne radiation counters. Fluorine and vanadium have been produced as by-products; uranium, nickel, molybdenum, and chromium are potential by-products; and about 20 other metals commonly occur in trace amounts (Gulbrandsen, 1966, table 1).

In the western phosphate field, phosphorite occurs in three different Permian formations, Phosphoria, Park City, and Shedhorn Formations; a little occurs in some underlying Mississippian strata. The three Permian formations are of different compositions which interfinger or grade laterally into one another. The Phosphoria cherts and shales and the Park City cherts, shales, carbonate rocks, and sandstones comprise the main part of the field, but: the Shedhom sandstone is found only in Montana and Wyoming.

The Phosphoria Formation in and near its type locality at Phosphoria Gulch, Bear lake County, Idaho, is 250-450 ft thick; the formation thickens to about $1,300 \mathrm{ft}$ in south-central Idaho. It consists of four members

\section{I'Ocean water is constantly moving, even on the bottom. Where deep,} cold ocean currents impinge on a continental shelf, or on each other, they may be diverted upward to the surface where the water is warmed. Since the ocean is nearly saturated with phosphate, which is 30 times more soluble in cold than in warm water, the upwelling water becomes supersaturated and phosphate is precipitated in shallower water as pellets that accumulate with silt, chert, Iimestone, and organic material to form phosphorite.

2/ The terms "phosphorite" and "phosphate rock" both apply to any rock containing commercial amounts of phosphorus, but "phosphorite" is usually restricted to deposits of marine origin. 
underlain by siliceous dolomite of the Grandeur Formation (Permian) and overlain by limy shale of the Dinwoody Formation (Triassic). In one measured section the thickness of the oldest member, the Meade Peak $\therefore \quad$ Phosphatic Shale, is $200 \mathrm{ft}$; it is overlain successively by Rex Chert (156 ft), Cherty Shale (67 ft), and the Retort Phosphatic Shale Member (30 ft).

The Park City Formation near its type locality in Big Cottonwood Canyon near Salt Lake City, Utah, is about $800 \mathrm{ft}$ thick. It consists of three members underlain by a thin limestone bed at the top of the Weber Quartzite (Pennsylvanian) and overlain by red shales of the Woodside Formation (Triassic). The oldest member, the Grandeur Dolomite, is $278 \mathrm{ft}$ thick; it is overlain successively by Meade Peak Phosphatic Shale ( $300 \mathrm{ft}$ ) and Franson dolomite-sandstone-chert $235 \mathrm{ft}$ thick (McKelvey and others, 1959).

The Meade Peak Member is the main source of phosphorite in the southern part of the western phosphate field; the Retort Member is mined in Montana. In some places the shales contain beds a few inches to $22 \mathrm{ft}$ thick of nearly pure phosphatic material containing as much as 39 percent $\mathrm{P}_{2} \mathrm{O}_{5}$. High-grade phosphorite contains over 31 percent $\mathrm{P}_{2} \mathrm{O}_{5}$ and is commonly mined from beds 2-7 ft thick. Low- or furnace-grade rock averaging 24 percent $\mathrm{P}_{2} \mathrm{O}_{5}$ or more is mined from beds as much as $40 \mathrm{ft}$ thick. Most phosphorite is mined fyom open pits, and production of a million tons or ore a year is common. 1

In Nevada, the Phosphoria extends as far west as the Adobe Range in Elko County and reaches a maximum thickness of about 4,000 ft in northeastem Elko County, but the thickness of the Meade Peak Member is only 25-100 ft. The Retort Member grades laterally into the Cherty Shale Member or into bioclastic Iimestone which, in Elko County, are not phosphatic. The Park City Formation grades laterally westward into, or intertongues with, the Park City Group of three formations, the Kaibab Limestone (oldest), the Plympton dolomite-chert-mudstone-limestone-sandstone, and the Gerster Limestone (youngest). They extend as far south as the Schell Creek Range in White Pine County and in southeastem Elko County they total about 1,700 ft thick. The Plympton Formation is the partial equivalent of the Meade Peak Member of the Park City Formation. In contrast to the Kaibab and Gerster it is nonfossiliferous and locally contains thin beds of phosphatic black chert and carbonate rock.

In the southern Pequop Mountains, the Plympton Formation (equivalent to the Meade Peak Member of the Park City Formation) is about 1,100 ft thick. It contains thin beds of phosphorite in the lower $200 \mathrm{ft}$, which is predominantly cherty, and also in the middle $300 \mathrm{ft}$ and upper $200 \mathrm{ft}$,

1 'Prices for most phosphate rock are based on the percent BPL (bone phosphate of lime), which is tricalcium phosphate, $\mathrm{Ca}_{3}\left(\mathrm{PO}_{4}\right)_{2}$. In the Western States analyses are usually reported in percent $\mathrm{P}_{2} \mathrm{O}_{5}$ $\left(\% \mathrm{P}_{2} \mathrm{O}_{5} \times 2.184=\% \mathrm{BPL}\right)$. "Spot" and contract prices are negotiated and are not quoted in trade journals, but averages for various grades are shown in Minerals Yearbook (U.S. Bur. Mines, 1925-73). 
which are mostly dolomitic (Yochelson and Fraser, 1973, p. 22). In the localities explored, the phosphorite beds are nearly vertical and extend for about 10 miles northeastward along the summit and also along the lower east flank of the range. The greatest thickness sampled was $36.2 \mathrm{ft}$ that assayed 10.5 percent $\mathrm{P}_{2} \mathrm{O}_{5}$; the highest grade was 20.2 percent $\mathrm{P}_{2} \mathrm{O}_{5}$ across $6 \mathrm{ft}$.

\section{Pilot Peak district}

Location and history

\begin{tabular}{llll}
\hline Sections & T. R. & Quadrangle name & Remarks \\
(Approx.) & N. E. & ( $7 \frac{1}{2}$ or 15 minute) & .
\end{tabular}

$\begin{aligned} & \text { All } 3670 \quad \text { Pilot Peak, Shafter } 1 \text { NE. Pilots Peak district } \\ & \text { Pilot Mountain district }\end{aligned}$

The district covers the south end of the Pilot Range south of Pilot Peak, altitude 10,704 ft. Gold and silver mines and prospects are at altitudes of $6,000-6,200 \mathrm{ft}$ on the lower southeast slopes.

A few tons of silver-copper-gold ore was produced in 1936 and a little gold-silver ore in 1936 and 1938.

\section{Geologic setting}

Pilot Peak is composed mainly of sedimentary rocks, the oldest $c$ : which are argillites and conglomeratic quartzites of Precambrian age exposed at the west base of the peak. They are overlain by Prospect Mountain Quartzite of Cambrian age that extends to the summit. The lower south and east slopes are mainly east-dipping limestones of Cambrian. through Pennsylvanian ages. These sedimentary formations are displaced a few feet to several thousand feet along normal faults that strike generally northward or eastward. Small outcrops of Tertiary intrusive rocks occur along the east side of the range, and fragments of diorite and granodiorite were found on the limestone dump of the crosscut adit in sec. 20.

Proctor district

Location and history

\begin{tabular}{|c|c|c|c|c|}
\hline $\begin{array}{l}\text { Sections } \\
\text { (Approx.) }\end{array}$ & $\begin{array}{l}\text { T. } \\
\text { N. }\end{array}$ & $\begin{array}{l}\text { R. } \\
\text { E. }\end{array}$ & $\begin{array}{l}\text { Quadrangle name } \\
\text { ( } 7 \frac{1}{2} \text { or } 15 \text { minute) }\end{array}$ & Remarks \\
\hline All & 35 & 68 & - Shafter(?) & Silver Zone district \\
\hline All & 34 & 68 & & Limestone \\
\hline (?) & 34 & 69 & & Placer claims \\
\hline
\end{tabular}

The district includes Silver Zone Pass in the Toano Range. Silvercopper deposits are about a mile north of Proctor, a station on the Westem Pacific Railroad; the railroad crosses a productive tungsten deposit about a quarter of a mile northeast of Silver Zone Pass. 


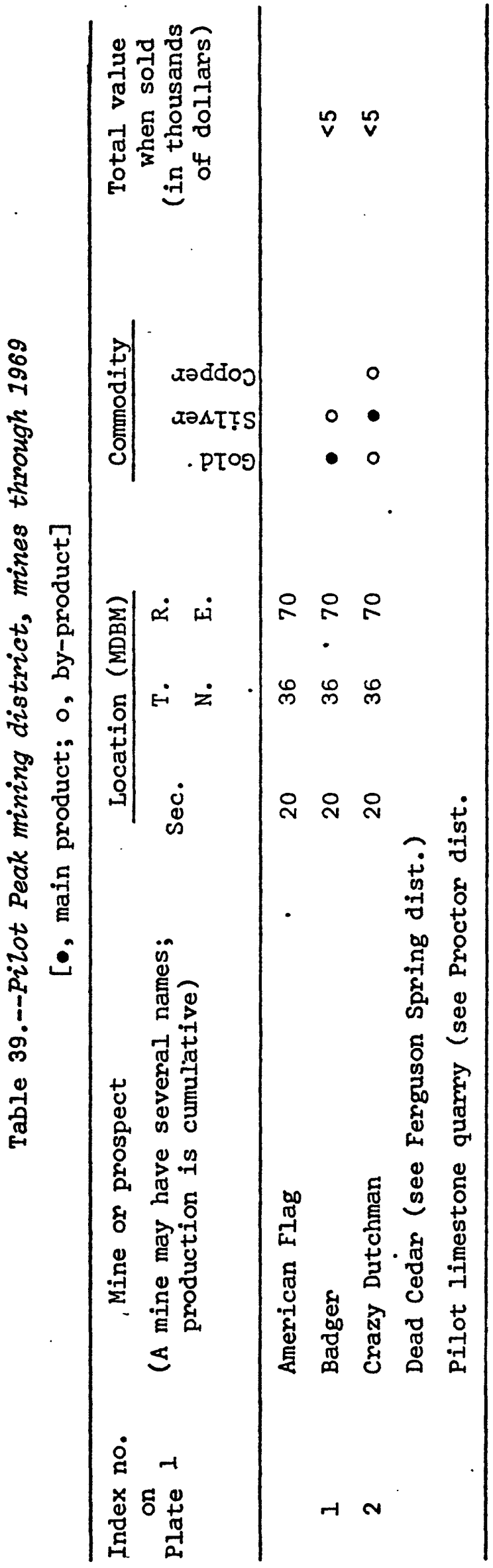


Production of silver and silver-copper ores was reported for the year 1917 and of tungsten ore for 1942. Limestone was mined from the Pilot quarry half a mile west of Pilot siding by Utah Construction and

$\therefore$ Mining Co. during 1960; a sample shipment was made to an out-of-state lime plant. Land Office records are filed under "Unknown mining district." They include patent surveys of three placer claims listed in table 40.

Geologic setting and ore deposits

Limestones and hornfels of Cambrian and Ordovician ages that dip about $35^{\circ}$ eastward are intruded by a Jurassic granodiorite stock about 2 miles across which is exposed on both slopes of the Toano Range both north and south of the pass. The granodiorite is cut by steep faults that strike north, northeast, and northwest; a few of the north- and northeaststriking faults contain quartz veins as much as $10 \mathrm{ft}$ wide. Some of the veins contain a little pyrite and argentiferous galena, and a few small lenses of scheelite ore, but over most of their lengths they are barren.

The tungsten deposits are scheelite-bearing quartz veins, four of them about a quarter of a mile northeast of Silver Zone Pass near and north of the railroad, and four others on the west side of the pass. Only one of the middle veins on the east side has been mined. It is a vertical north-striking vein $3-4 \mathrm{ft}$ wide exposed for $650 \mathrm{ft}$ north of the railroad and again for $50 \mathrm{ft}$ about $150 \mathrm{ft}$ south of the tracks. The vein is displaced as much as $40 \mathrm{ft}$ by four transverse faults.

The ore shoot that was mined was about $300 \mathrm{ft}$ north of the railroad. It contained scheelite crystals one-fourth of an inch across in a mineralized layer as much as 18 inches thick along the east wall of the vein for a length of $40 \mathrm{ft}$ and a depth of $35 \mathrm{ft}$. It averaged about $1 \frac{1}{2}$ percent $\mathrm{WO}_{3}$; one shipment of 27 tons of sorted ore contained 8.5 percent $\mathrm{WO}_{3}$ (M. R. Klepper, written commun., 1942).

\section{Railroad district}

$\because \quad$ Location and history

\begin{tabular}{lllll}
\hline $\begin{array}{l}\text { Sections } \\
\text { (Approx.) }\end{array}$ & $\begin{array}{l}\text { T. } \\
\text { N. }\end{array}$ & $\begin{array}{l}\text { R. } \\
\text { E. }\end{array}$ & $\begin{array}{l}\text { Quadrangle name } \\
\left(7 \frac{1}{2} \text { or } 15 \text { minute }\right)\end{array}$ & $\begin{array}{c}\text { Other district names, } \\
\text { remarks }\end{array}$ \\
\hline $\mathrm{SE}^{\frac{1}{4}}$ & 31 & 52 & Carlin & Barite mines \\
$\mathrm{S}^{\frac{1}{2}}$ & 31 & 53 & Carlin, Dixie Flats & Bullion \\
$\mathrm{NE}^{\frac{1}{4}}$ & 30 & 52 & Carlin, Pine Valley & \\
$\mathrm{N}^{\frac{1}{2}}$ & 30 & 53 & $\begin{array}{l}\text { Carlin, Dixie Flats, } \\
\text { Pine Valley, } \\
\text { Robinson Mountain }\end{array}$ & Bullion \\
\hline
\end{tabular}




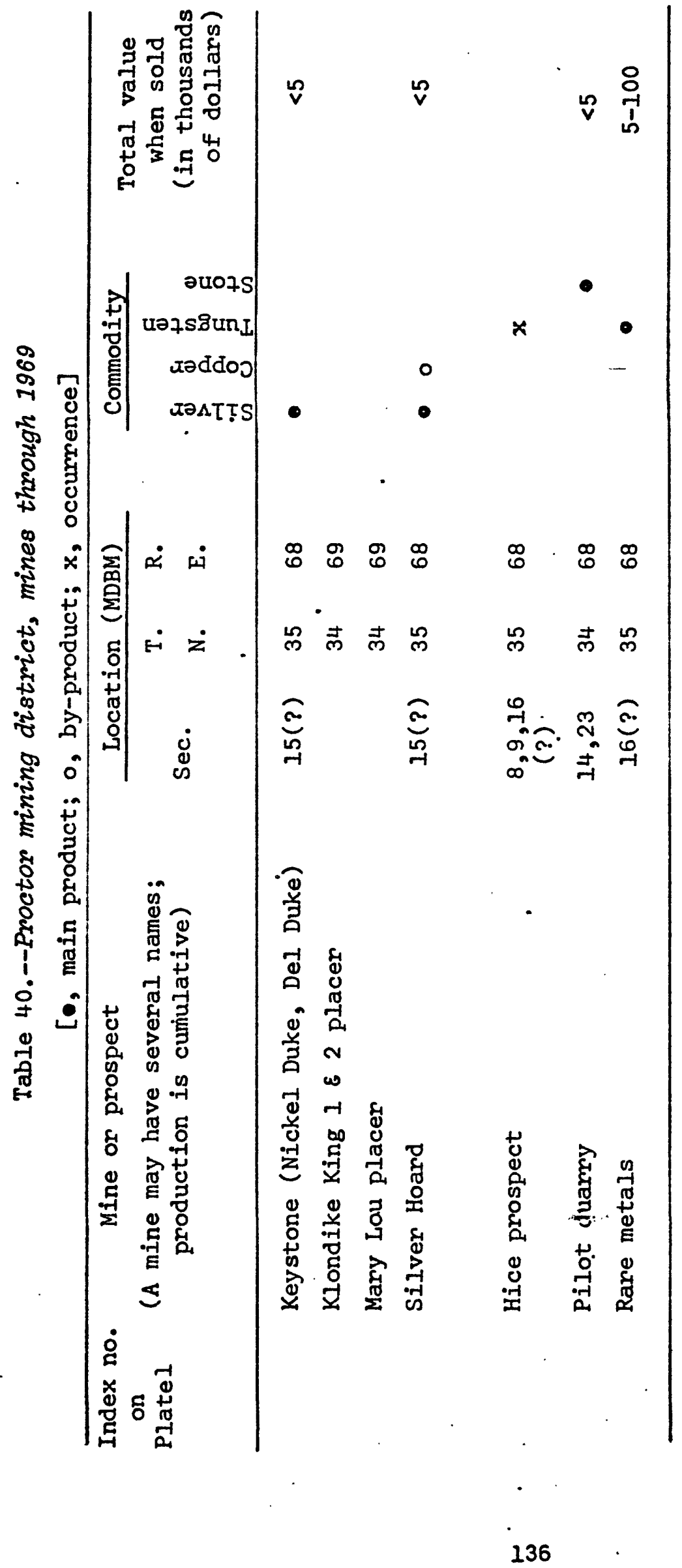


The Railroad district, probably so named because it was only 12 miles from the Central Pacific (now Southem Pacific) Railroad at Palisade, has also been called the Bullion district, but the latter name is discouraged since there is a Bullion district in Lander County. Organized in 1869, the Railroad district included the silver-lead-copper mines and the nearby camp of Highland, all high on the slopes of Bullion (Bunker) Hill, a north-trending spur of Ravens Nest which is the highest peak (altitude $8,710 \mathrm{ft}$ ) in the Pinon (Pinyon) Range.

During the early 1870's the district was called the Empire City district after the name of a mining company which erected a fumace of local sandstone having a smelting capacity of 15 tons of ore per day. The "Empire City district, J. M. Hussey, superintendent," was listed by Whitehill (1875, p. 164 ) in a table showing the net proceeds $(\$ 17,470.50)$ of the mine for the year 1873.

By 1873 , two smelters were in operation at Bullion City (Old Bullion) treating ores from the Standing Elk and seven smaller mines (Emmons, 1910, p. 89-95). Production continued through 1887, then ceased entirely until 1905 (Granger and others, 1957, p. 127) when the properties were consolidated and two low-level adits were started at the new camp of Bullion between Highland and Bullion City. The longer Davis Tunnel was driven to explore the projected downward continuation of the Standing Elk ore bodies $1,000 \mathrm{ft}$ below the 600 level and $6,040 \mathrm{ft}$ from the portal. (The target area was finally reached in 1959, but no ore was found.) The Webfoot Tunnel, sharing the same portal area and dump, has a 900-foot drift and several hundred feet of crosscuts below the Webfoot workings. Since 1910 most of the intermittent production is credited to the Aladdin mine which includes the Standing Elk group with more than $10,000 \mathrm{ft}$ of underground workings. Of the total estimated production through 1968 valued at $\$ 4,715,189$ (table 5), only about $\$ 1,734,000$ is recorded (Ketner and Smith, 1963, p. Bl7).

Since about 1930, the district has included barite deposits on Dixie Creek and on the west slopes of Pine Mountain. The Dixie (Snow White) minie produced a few hundred tons of. barite in 1955.

\section{Geologic setting}

The Piñon Range in the area of Ravens Nest consists of sedimentary rocks (Ordovician-Mississippian) about a mile thick, which have been folded, faulted, intruded by a granitic stock and by rhyolite porphyry dikes, and metamorphosed, hydrothermally altered, and mineralized near the stock. Most of the ore mined was along intersections of dikes and faults.

The sedimentary rocks along the crest of the range in a belt about a mile wide are predominantly dolomite and limestone about 2,300 ft thick of the Lone Mountain, Nevada, and Devils Gate Formations. Along the west slopes of the range they are overlain by argillite and quartzite units and by black siliceous argillite about 3,000 ft thick of Mississippian age. The east slopes are covered by Tertiary volcanic rocks a few hundred feet thick (Ketner and Smith, 1963, pl. 1). 
The sedimentary rocks are folded and locally overturned along the Pinon Range anticline, but in general the beds on the east side of the range dip east and those on the west side dip west. Along the west side of the anticline black siliceous argillite overlies the argillite-quartzite units, probably along a bedding-plane thrust fault younger(?) than the Roberts Mountains thrust of Late Devonian to Early Mississippian age. In the central part of the anticline the strata are complexly displaced along reverse and normal faults of all attitudes having displacements of a few inches to a thousand feet or more. Elsewhere in the Piñon Range, concealed faulted segments of Roberts Mountains thrust breccia are inferred between the Nevada limestone and the overlying siliceous formations.

A stock of quartz diorite-granodiorite-monzonite 4,000 ft across intrudes the limestone-dolomite-argillite strata near the axis of the anticline. Along the intrusive contact on the east side of the scock the limestone is metamorphosed to tactite in a zone 3,000 ft long and 100-400 ft wide, and at distances up to about 1,000 beyond the limestorse is marbleized. The stock has a core 2,500 ft across of rhyolite (auantz) porphyry and dikes of similar rhyolite porphyry cut the rim of the stock, the tactite, and the surrounding strata within a mile of the stock. Tis largest of these dikes, 4,000 ft long and as much as $700 \mathrm{ft}$ wide, tren $\vdots$ s northward about 4,500 ft east of the stock. Most of the ore deposits are between this dike and the stock.

\section{Ore deposits}

Three types of deposits have been mined: replacement and conzactmetamorphic deposits of copper, lead, silver, and zinc in the Bunker Hill area, and barite veins on the west side of Pine Mountain. Four other types, gold-bearing quartz veins, disseminated copper-molybienum, scheelite-bearing tactite, and halloysite alteration deposits, are too low grade or too small to be commercial as of 1971 .

Most of the ore mined was from replacement deposits in the Standing Elk (Aladdin) mine. Here the ore bodies are pipelike replacement bodies in marbleized limestone along the Bunker Hill and other rhyolite porphyry dikes at their intersections with faults. The largest ore body was about $50 \mathrm{ft}$ in diameter, extended through a vertical range of about $400 \mathrm{ft}$, and yielded more than 50,000 tons of oxidized ore containing 18.2 percent lead, 5.4 percent copper, and 19 oz of silver per ton. Oxidation is nearly complete to depths of about $500 \mathrm{ft}$. The ore minerals are cerussite, cerargyrite, copper pitch, duftite, malachite, azurite, chrysocolla, cuprite, and chalcocite, with some residual argentiferous galena, chalcopyrite, bornite, and sphalerite. The most abundant gangue minerals are quartz, calcite, kaolinite, iron and manganese oxides, halloysite, barite, and residual pyrite and pyrrhotite.

Contact metamorphic deposits of copper and iron sulfides in tactite were mined in the Sweepstakes (Delmas) mine. In some parts of the tactite, pyrite, pyrrhotite, chalcopyrite, bornite, galena, and sphalerite are intergrown with gamet, diopside, and other skam minerals. Locally the sulfides are partly oxidized to copper carbonates and iron oxides or 
coated with chalcocite, but oxidation is not complete, even at the surface. Some shipments before 1908 averaged $70 \mathrm{oz}$ silver per ton, 10.4 percent copper, and 2.8 percent lead (Emmons, 1910, p. 95).

Barite deposits were discovered on the west slopes of Pine Mountain about 1930 and nearly 2,500 tons was mined in 1931, 1956, and 1957. The deposits are veins in limestone of the Nevada Formation.

Deposits of the following commodities occur in the same or other types of deposits but are not of commercial size and (or) grade.

Beryllonite occurs in small quantities with duftite in the oxidized replacement deposits.

Gold occurs in quartz veins that cut the granitic stock. The largest vein, which is near the Delmas mine, is exposed here and there for $500 \mathrm{ft}$ along the stike, is $2-4 \mathrm{ft}$ wide, and was said to carry about $0.07 \mathrm{oz}$ gold per ton (Emmons, 1910, p. 93).

Hematite occurs in replacement deposits in limestone near an intrusive contact on the Silver King and Sun claims (table 41). The exposures are 3-60 ft wide and a few feet to $200 \mathrm{ft}$ long. Small lenses are of ore grade, but most of the material is estimated to contain less than 40 percent $\mathrm{Fe}$ (Shawe and others, 1962).

Ilmenite derived from volcanic rocks occurs with magnetite in placer deposits in the Dixie Creek area (T. 31 N., R. 54 E.). A placer sample contained 5.9 percent ilmenite and 44 percent magnetite. Surface samples contained a maximum of 0.3 percent $\mathrm{TiO}_{2}$ (Beal, 1963, p. 15).

Magnetite and some intergrown hematite occur with garnet and diopside in the contact metamorphic deposits.

Halloysite is abundant on the 500 level of the Standing Elk mine and in many of the mine dumps, but none was found on the Davis Tunne? level.

$\therefore$ Molybdenite occurs with chalcopyrite disseminated in the rhyolite porphyry. Exploratory drill holes from the surface indicate increasing amounts with depth. Samples from one of the holes assayed 0.01-0.3 percent copper and 0.01-0.09 percent Mo (H. K. Stager, written commun., 1970).

oil shale occurs in sedimentary rocks of Tertiary age along the east side of the Piñon Range (Ketner, 1970, p. B108).

Scheelite-bearing tactite 2-3 ft wide is exposed for $30 \mathrm{ft}$ in the Davis Tunnel about $3,000 \mathrm{ft}$ from the portal. Assays ranged from 0.3 to 4.3 percent $\mathrm{WO}_{3}$. Tactite is also exposed in the Tripoli mine and on the surface 1,000 ft above the Davis Tunnel. A beryllium-rich mineral occurs in tactite at an unidentified location.

Wollastonite is abundant in large zones of intensely silicated limestone on the Davis Tunnel level. 


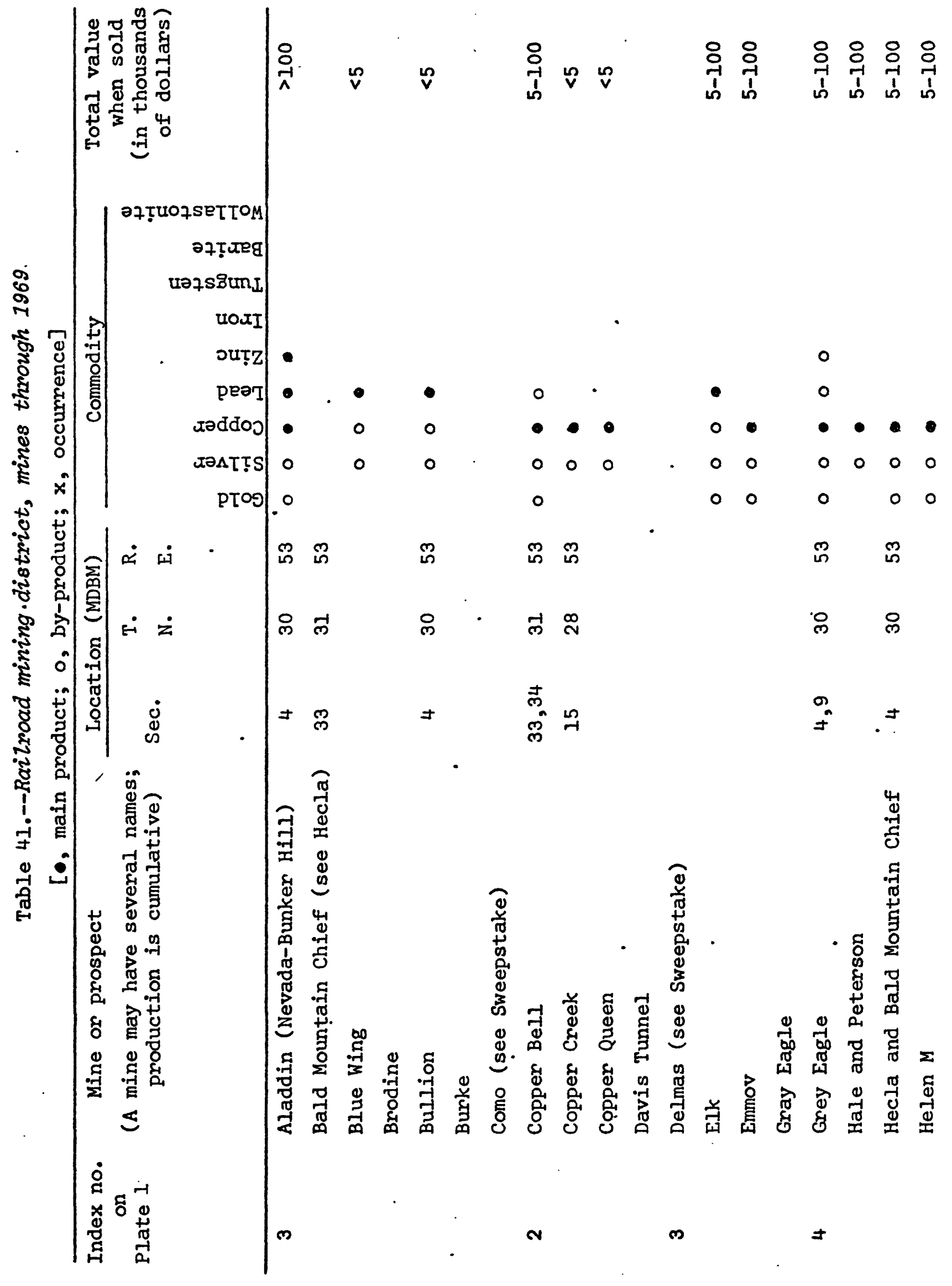




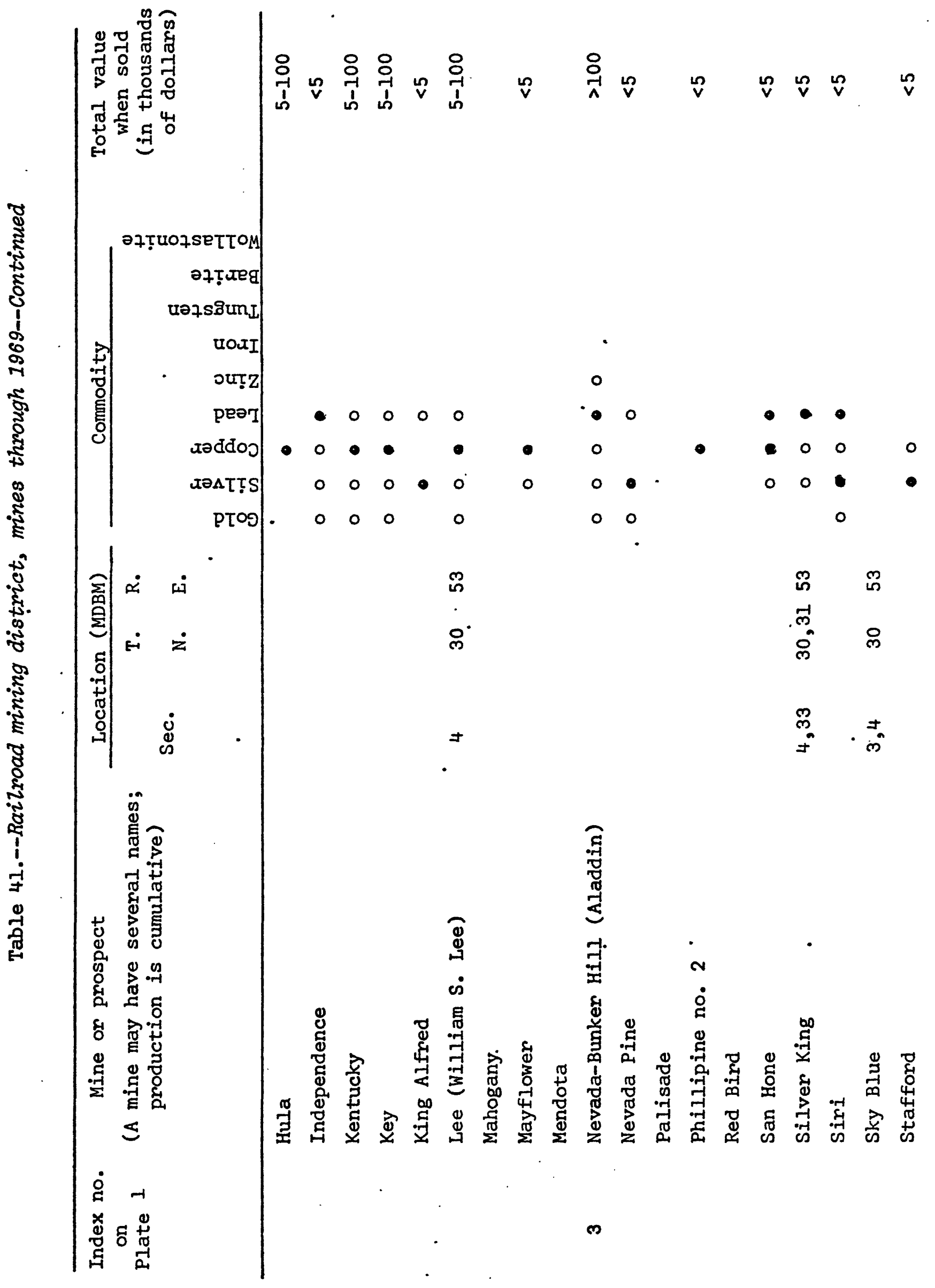




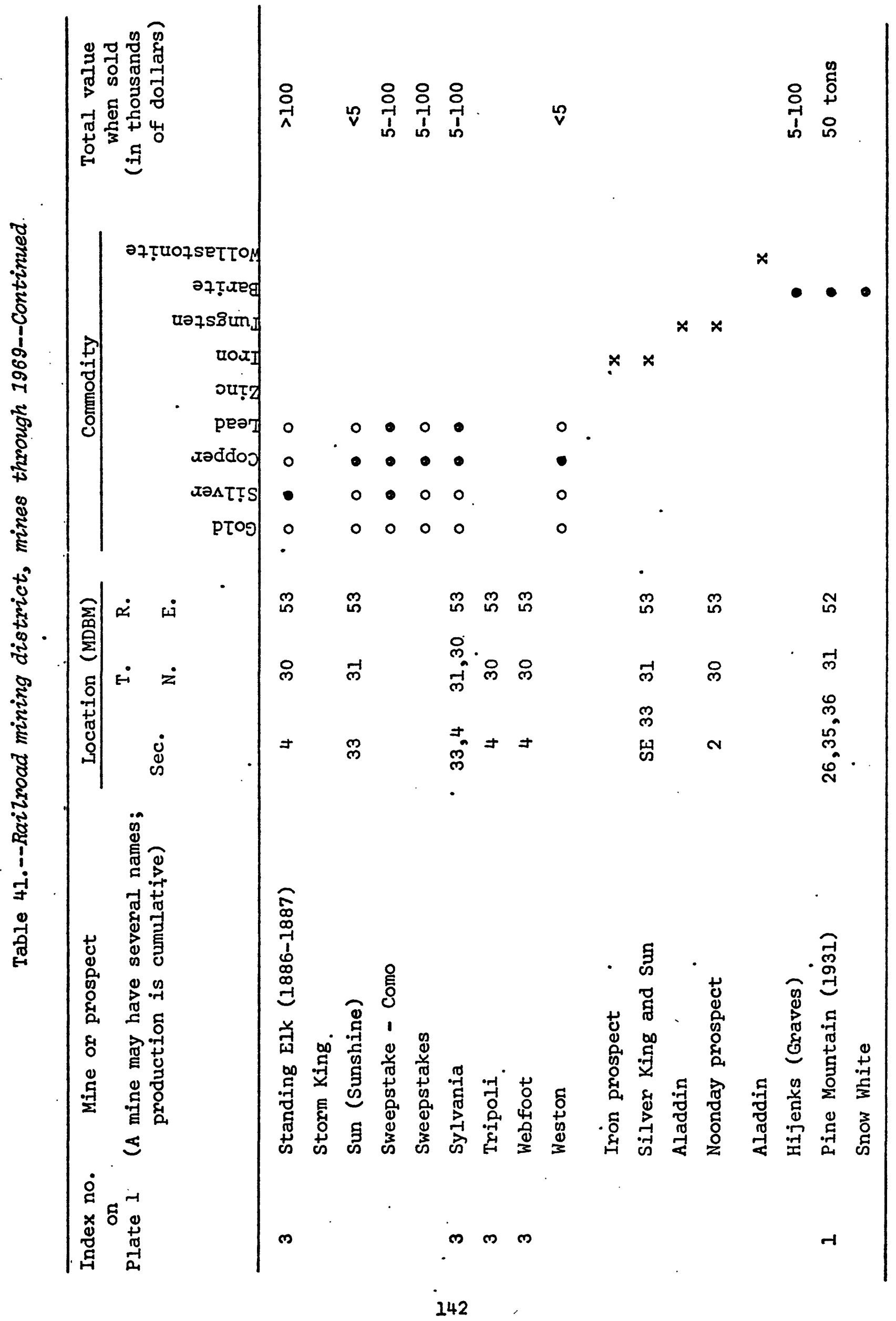


Robinson Mountain district

Location and history

\begin{tabular}{|c|c|c|c|c|}
\hline $\begin{array}{l}\text { Sections } \\
\text { (Approx.) }\end{array}$ & $\begin{array}{l}\text { T. } \\
\text { N. }\end{array}$ & $\begin{array}{l}\text { R. } \\
\text { E. }\end{array}$ & $\begin{array}{l}\text { Quadrangle name } \\
\text { ( } 7 \frac{1}{2} \text { or } 15 \text { minute) }\end{array}$ & Other district names, remarks \\
\hline$N E^{1 / 4}$ & 29 & 52 & Pine Valley & Asphaltite \\
\hline $\mathrm{N} \frac{1}{2}$ & 29 & 53 & $\begin{array}{l}\text { Robinson Mountain, } \\
\text { Pine Valley }\end{array}$ & Barite \\
\hline$S \frac{1}{2}(?)$ & 29 & 53 & $\begin{array}{l}\text { Robinson Mountain, } \\
\text { Pine Valley }\end{array}$ & $\begin{array}{c}\text { Copper Canyon(?) } \\
\text {. }\end{array}$ \\
\hline
\end{tabular}

The Robinson Mountain area includes both. slopes of the Sulfur Spring Range for about 3 miles north and south of Robinson Mountain. The par: of the east slope of Robinson Mountain, in the drainage area of Robinson Creek, is also known as the Copper Canyon mining district (county reconis), but the name Robinson Mountain is preferred because there are two Copter Canyons in Lander County.

Small shipments of barite from an unnamed prospect in sec. 2, I. 2@ I. , R. $53 \mathrm{E}$. , is the only production reported from the district (Horton, $13: 3$, p. 8).

A 9-inch bed of grahamite and other bitumens in a sandstone stratin in conglomerate is reported by Southem Pacific Co. (1964, p. 126) in the $\mathbb{N}_{2} \mathrm{~N}_{2}^{\frac{1}{2}}$ sec. $1, \mathrm{~T} .29 \mathrm{~N}$, R. $52 \mathrm{E}$. The deposit contains over 0.1 percent vanadium (Schilling, 1962d, map 10), and some uranium (Schilling, 19633, map 19).

Rock Creek district

Location and history

\begin{tabular}{|c|c|c|c|c|}
\hline $\begin{array}{l}\text { Sextions } \\
\text { (Approx.) }\end{array}$ & $\begin{array}{l}\mathrm{T} \\
\mathrm{N}\end{array}$ & $\begin{array}{l}\text { R. } \\
\text { E. }\end{array}$ & Quadrangle name & - Other district names \\
\hline$E^{1 / 2}$ & 40 & 48 & McDermitt $2^{\circ}$ & Falcon \\
\hline AlI & 40 & 49 & Mt. Blitzen $15^{\prime}$ & \\
\hline
\end{tabular}

The Rock Creek district is in mountainous terrain in the Rock Creek drainage area west of the main Tuscarora Mountains, between 10 and 20 miles west of the town of Tuscarora.

Silver ore was discovered in 1876, and the Falcon mine was worked from 1879 to 1881. The Ruby king mine produced 3 tons in 1922; the April Fool group, 34 tons in 1928 and 14 tons in 1.950; and the Silver Globe, 7 tons in 1938. Cinnabar was discovered in the district as early as 1929; the Teapot and Horse Mountain $1 \& 2$ mines produced 81 tons of ore containing 23 flasks of mercury during 1954-57. 


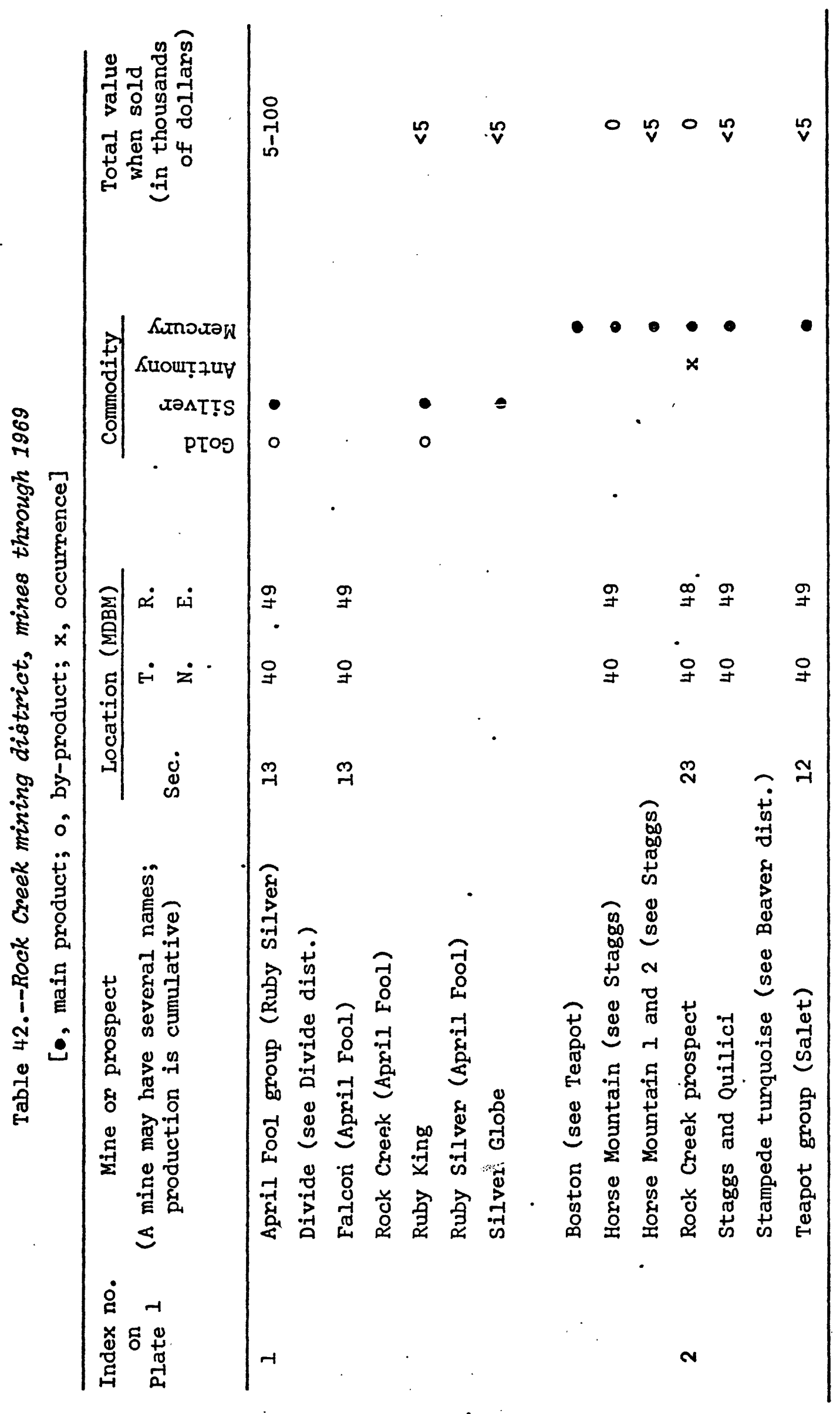


In 1964, an area along Rock Creek below the Teapot mine was explored by the Cordero Mining Co. with 116 vertical churn drill holes ranging in depth from 6 to $96 \mathrm{ft}$. Traces of cinnabar were found in 38 holes and

$\therefore$ mineralized rock of ore grade in six holes. The best assay was $9.7 \mathrm{lb}$ of mercury per ton for a width of $12 \mathrm{ft}$ (Ed Hager, oral commun., 1973).

Geologic setting and ore deposits

Sedimentary rocks of the Valmy Formation (Ordovician) and the Havallah sequence (Mississippian-Permian) are overlain by andesite and rhyolite flows and silicic tuffs of Eocene age. These formations are intruded by the Mount Neva granitic stock just east of the district and by two rhyolitic stocks, each about a mile across, just north of the district. The stocks are all of Tertiary age. Erosion remnants of rhyolite and tuffaceous sedimentary rocks of Miocene age overlie the intruded rocks. Silver deposits are in the eastem part of the district about 2 miles from the Mount Neva stock. Mercury deposits are in the westem part of the district 4-5 miles from the rhyolite stocks.

At the Falcon mine, andesite is cut by a north-trending vertical fault along which a quartz vein $2-5$ Et wide was mined for ruby silver. There is no record of the amount mined under that name, but later prosuczion under the name of the April Fool gnoup averaged about $0.35 \mathrm{oz}$ gold and 428 oz silver per ton.

At the Teapot mine and at the Rock Creek prospect(?) andesite is Cu: by north-trending faults that dip steeply east. Along the faults, cinnajar occurs with pyrite in quartz veinlets and disseminated in altered andesite. Some stibnite is said to accompany the cinnabar at the Rock Creek prospect (Bailey and Phoenix, 1944, p. 63). Average grade of the recorded production was $21.6 \mathrm{lb}$ of mercury per ton of ore treated.

\section{Ruby Mountain Range district (1915-29)}

$$
\text { Ruby Range district (1949-58) }
$$

$\because$ These omnibus names have been used in official records since 1915 for about 20 mines in unknown or unnamed districts in the Ruby Mountains and East Humboldt Range. In this report the mines are distributed either to a named district or to Unknown districts (table 54) as indicated in tables 43 and 44 .

Production credited to Ruby Mountain Range and Ruby Range is 5,662 tons of lead-zinc ores containing some copper and a little silver and gold valued at about $\$ 201,000$. This production is included with the figures for Undistributed production in table 5 . 


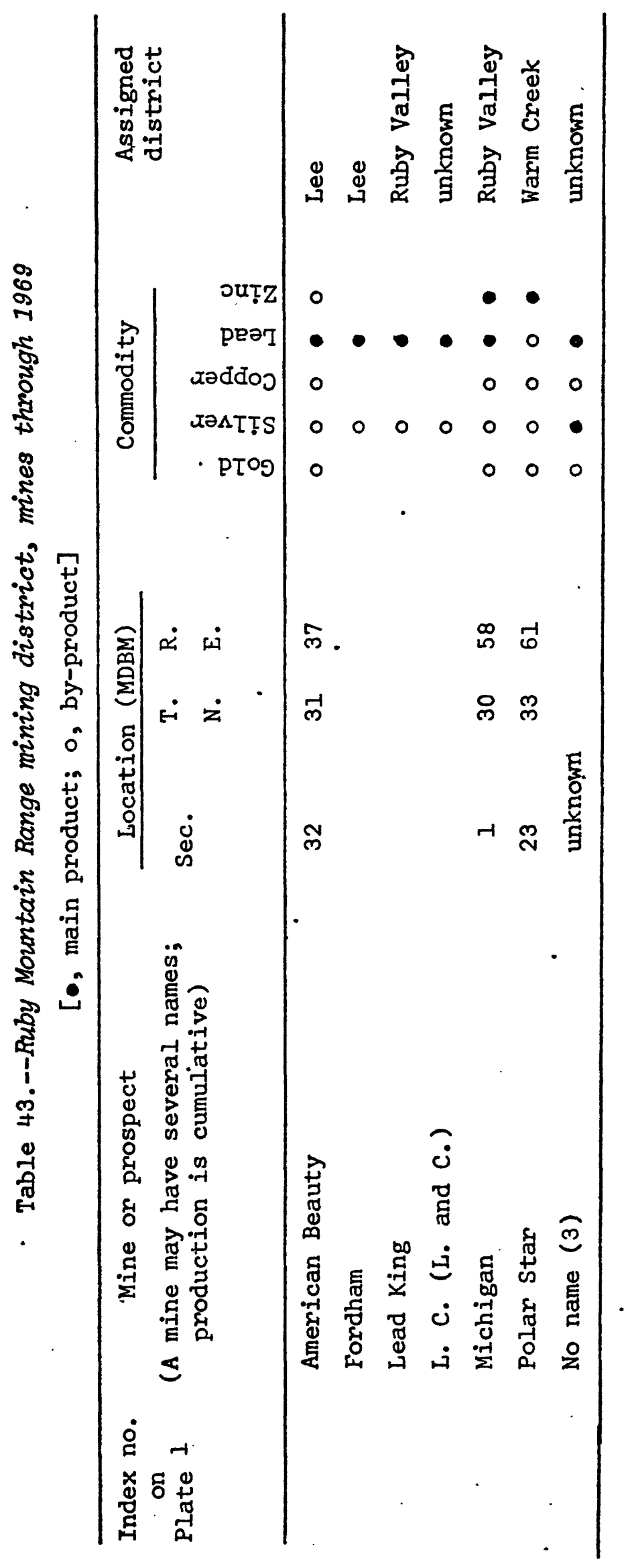




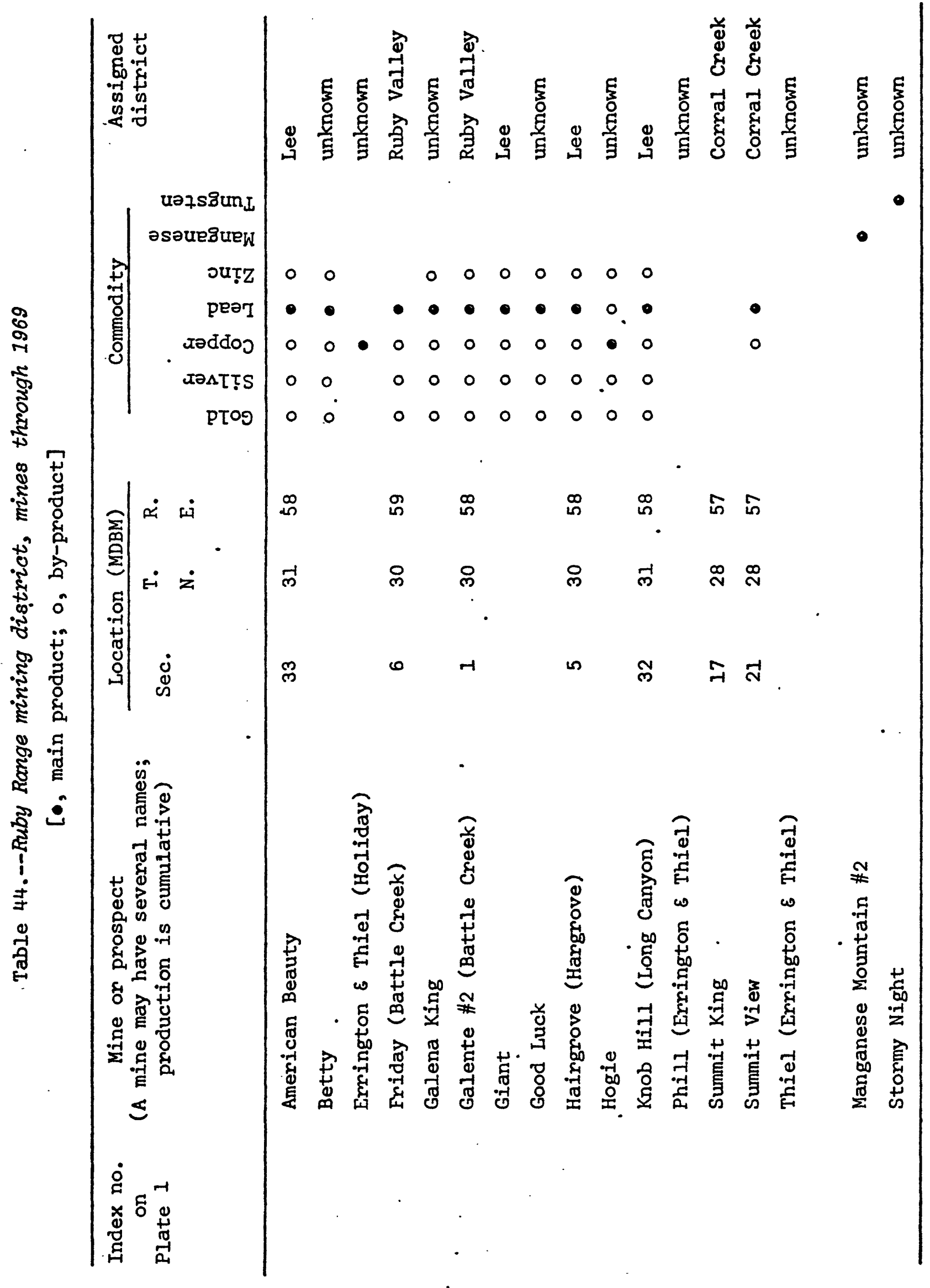


Ruby Valley district

Location and history

Sections T. R. Quadrangle name

(Approx.) N. E. (71/2 or 15 minute)

Other district names

NE 3058 Lamoille, Franklin ' Smith Creek, Ruby Range

$6,7,18 \quad 30 \quad 59$ Lamoille, Franklin

Lake NE

The Ruby Valley district covers the drainage areas of Battle Creek and Meyers Creek, including Smith Gulch, on the east slope of the Ruby Mountains opposite the north enc of Franklin Lake. Smith Creek is on the opposite side of the range.

Lead-zinc-silver ore was discovered and the Short group of claims was staked in 1903. Production From the Friday (Battle Creek) group is recorded for intermittent yeans Enom 1908 through 1955 and from the district through 1967. Scheelite $\because \equiv s$ mined at the Battle Creek mine during $1944-46$.

The unnamed district in T. 32 N., R. 59 E., listed by Lotz (1934, p. 18), contains a Smith Creek and may be the Ruby Valley district.

Geologic serting and ore deposits

The Ruby Valley district czrers areas of Prospect Mountain Quartzite and marbleized Iimestones of Cambrian age intruded by granites of Jurassic and Cretaceous ages. These aress include the northeastern part of the intrusive complex summarized under Valley View district.

In the Ruby Valley district the mines are in a narrow belt of white crystalline limestone of Camirian age which strikes about $\mathrm{N} .60^{\circ} \mathrm{E}$. and dips $45^{\circ}-60^{\circ} \mathrm{N}$. The limestone has been intruded by biotite granite of Jurassic(?) age. Near or along the intricate contact the limestone is metamorphosed in places to lenses of lime silicate rock commonly parallel with the bedding. Some of these contact metamorphic lenses contain lead, zinc, and copper sulfides, their oxidation products, a little silver, and a trace of gold. In most of the ore bodies galena was the main ore mineral, but in others sphalerite predominated (Hill, 1916, p. 60).

Highest yearly average grades for ores shipped since 1949 were 55 percent lead and 14.2 percent zinc from the Battle Ćreek group, 2.7 percent copper from the Copper King mine, and 1.3 oz silver per ton from the Noonday mine.

At the Battle Creek tungsten mine scheelite accompanied by a little quartz and pyrite occurs in two lenses of chlorite schist surrounded by granite and pegmatite. The largest lens has a maximum width of $10 \mathrm{ft}$ and is $100 \mathrm{ft}$ long. About 900 units of $\mathrm{WO}_{3}$ was produced from ore that averaged 1.5 percent $\mathrm{WO}_{3}$. A similar defosit, the Fawn Creek prospect south of Meyers Creek, was estimated to contain 0.5 percent $W_{3}$ but has not been productive (D. M. Lemmon, written commun., 1948). 


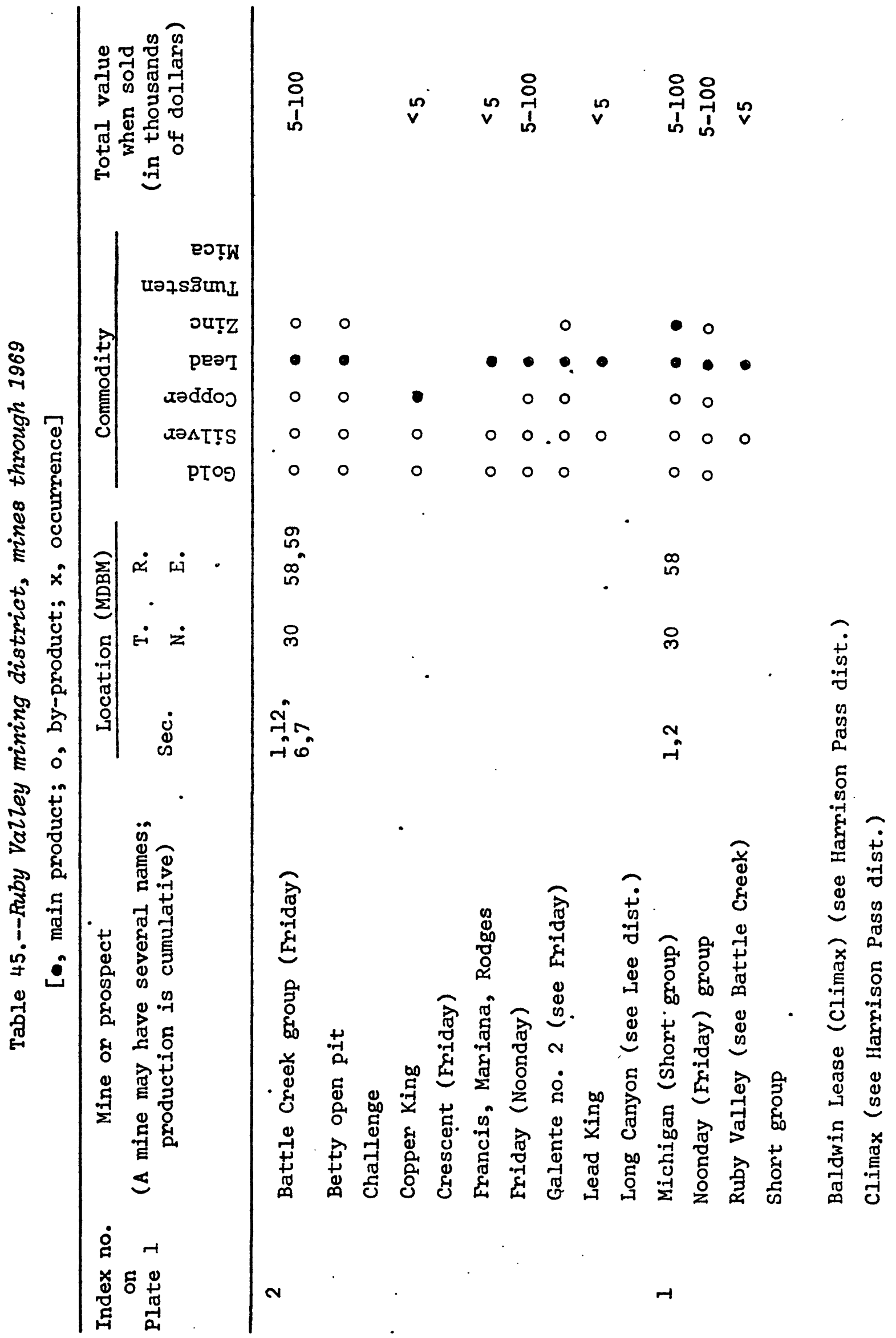




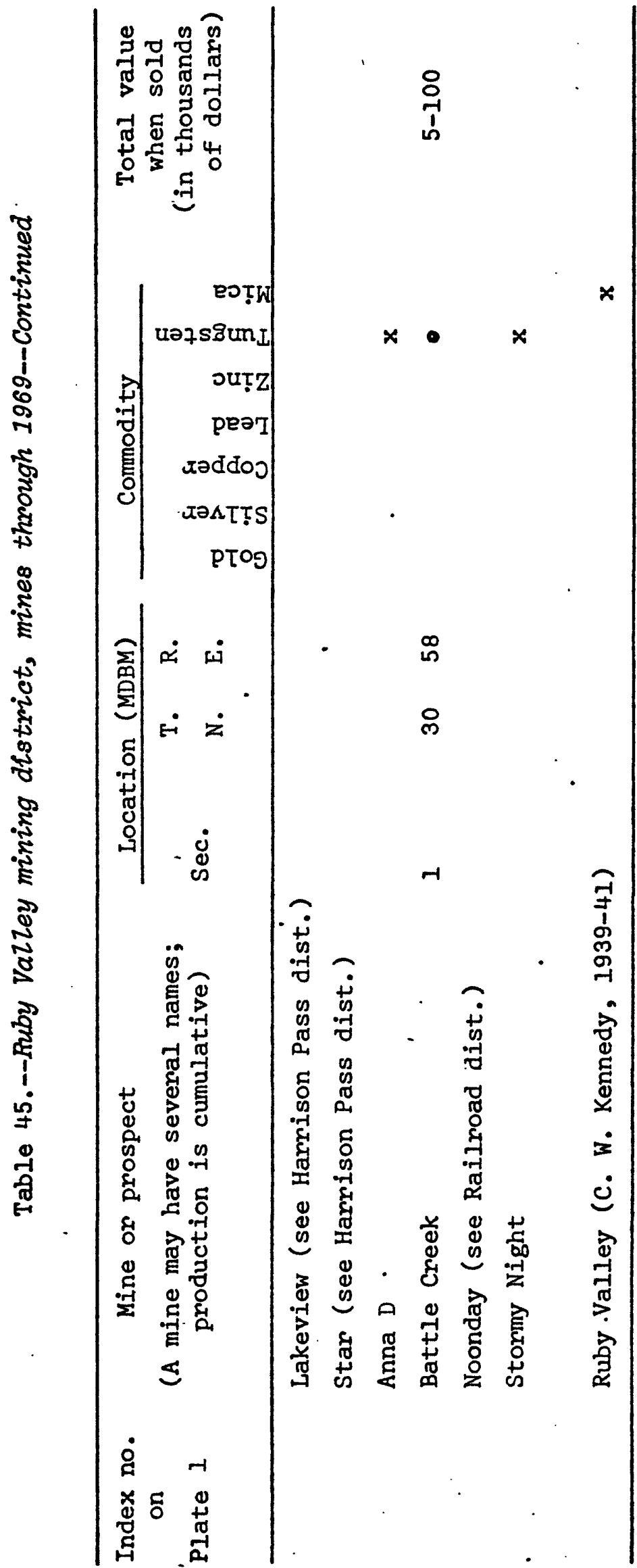


Spruce Mountain district

Location and history

\begin{tabular}{lllll}
\hline $\begin{array}{l}\text { Sections } \\
\text { (Approx.) }\end{array}$ & $\begin{array}{l}\text { T. } \\
\text { N. }\end{array}$ & $\begin{array}{l}\text { R. } \\
\text { E. }\end{array}$ & $\begin{array}{l}\text { Quadrangle name } \\
\left(7 \frac{1}{2} \text { or } 15 \text { minute) }\right.\end{array}$ & Remarks \\
\hline E-2/3 & 32 & 63 & Spruce Mountain & Many prospects \\
All & 31 & 63 & Spruce Mountain & Main part of district \\
W $\frac{1}{2}$ & 31 & 64 & Spruce Mountain & Mines and prospects \\
\hline
\end{tabular}

The Spruce Mountain district includes Spruce Mountain (altitude $10,262 \mathrm{ft})$, a somewhat isolated peak west of the axis of the Pequop Mountains, and Spruce Mountain Ridge which extends northward from the peak.

Lead-silver ores were discovered at the Latham (Killie) mine in 1569, and at the Juniper, Fourth of July, and Black Forest mines shortly afterwards. Three original districts, the Latham, Johnson, and Steptoe, were combined to form the Spruce Mountain district in 1871. The principal settlements were Sprucemont, on the lower west slope of the mountain, and Black Forest, on the upper east slope.

Two smelters, one of 35-tons-per-day capacity at Sprucemont and another of 50 tons in Independence Valley, treated the ores produced in the early days. After about 1903-06 most of the ores were shipped to newly built custom smelters in Salt Lake Valley, Utah; transportation charges on the ore amounted to about half its value. Another 50-ton smelter was built in 1917 to treat ores from the Bullshead and Black Forest mines, but only a trial run was made.

Production from the district has been intermittent, most of it during the years 1869-73. 1885-87, 1899-1909, and 1915-49. The most productive year was $1920(\$ 388,160)($ Lincoln, 1923, p. 56). No production was reported between 1961 and 1970 . $^{\circ}$

The mines are developed by several miles of underground workings including a 7,000-foot tunnel between the two deepest mines, the Black Forest $(400 \mathrm{ft})$ and the Monarch $(600 \mathrm{ft})$, which are on opposite sides of the mountain. The tunnel has a maximum depth of $800 \mathrm{ft}$. An aerial tram 6,800 ft long conveyed ore from the Killie and Black Forest mines to a truck-loading station. Pipelines more than 2 miles long from springs supplied water to Sprucemont and the Monarch mine camp.

All the largest mines are on Spruce Mountain, but several small mines and many prospects are located along the west foothills of Spruce Mountain Ridge. The Atlantic tungsten prospect was discovered in 1954 near the Keystone lead-silver mine, and the Devaney and White Boy barite deposits, prospected in 1956, are near Sprucemont. 


\section{Geologic setting}

The oldest rock exposed in the district is blue limestone of the Pogonip Formation of Ordovician age which crops out on the summit and

$\therefore$ west slope of Spruce Mountain, generally in beds $1-4 \mathrm{ft}$ thick. It is overlain or is in fault contact with limestones, dolomites, shales, and quartzites of Silurian through Permian ages (Hope, 1972). The sedimentary rocks are tilted gently to moderately eastward, displaced along the Spruce Mountain thrust fault, and cut by steep north-, northwest-, and east-trending normal faults. A dike of granite porphyry $500 \mathrm{ft}$ wide extends northeastward completely across the ridge, and three or more small irregular stocks of granite porphyry and diorite are intruded along and near the crest (Hill, 1916, p. 69). A lamprophyre dike was noted in the upper tunnel of the Black Forest mine (Schrader, 1931, p. 8).

Within $500 \mathrm{ft}$ of the intrusives, but generally less than $30 \mathrm{ft}$, the limestones are metamorphosed to a skarn of quantz, calcite, diopside, gamet, fluorite, actinolite, and other pyroxenes (Granger and others, 1957, p. 139). The largest metamorphic zone is on the west side of the range; it is $500 \mathrm{ft}$ wide and half a mile long at the west end and north of the main dike. Between them there are two prominent knoblike outcrops of iron-stained quartz breccia called "blowouts," the larger of wich is $500 \mathrm{ft}$ in diameter. On the east side of the range the northeastiard continuation of the zone of intrusives is marked by outcrops of jasperoic.

\section{Ore deposits}

Two kinds of metalliferous ore bodies were mined, bedded replacement deposits in limestone and fissure deposits along all three sets of normal faults in limestone, skam, quartz breccia, and granite porphyry. In addition to the metal mines two vein-type(?) deposits of barite and one contact deposit of scheelite have been prospected.

The bedded replacement ore shoots are commonly a few feet thick, as much as 100(?) ft long, and extend $100 \mathrm{ft}$ or less from the fissures into the limestone. Bedded replacement deposits yielded most of the early pröduction.

Vein ore shoots are as much as $15 \mathrm{ft}$ wide and $360 \mathrm{ft}$ long, but one fissure zone in the Spruce Standard mine is $20 \mathrm{ft}$ wide. In this zone of closely spaced mineralized fissures, sphalerite is the principal ore mineral (Schrader, 1931, fig. 7). In the Black Forest mine some ore shoots at fault intersections were pipelike or globular bodies $3 \mathrm{ft}$ or more in diameter, and at the Ada $\mathrm{H}$ mine a stockwork at intersecting fissures is $1,800 \mathrm{ft}$ or more in extent. In the Killie lode, ore was localized at intersections of the lode with many fissures or slips which strike in various directions. In 1930 the lode had a known extent of $450 \mathrm{ft}$ down a $28^{\circ}$ dip, a width of $100 \mathrm{ft}$, and a thickness of $40 \mathrm{ft}$ or more, and was estimated to contain 50,000 tons containing about. 10 percent lead, 10 percent zinc, 3 oz silver per ton, and a little gold (Schrader, 1931, p. 17). The deepest ore shoot in the district was mined to the 520-foot level in the Monarch mine. 
Different ore bodies contained different proportions of lead, silver, copper, and zinc, but most ore bodies were valued mainly for lead and silver. Ore bodies in which copper predominates occur along and near the $\therefore \quad$ intrusives, but zinc decreases with nearness to the granite porphyry in the Nevada Lead mine (table 46).

Oxidation extends irregularly to depths of $200 \mathrm{ft}$ or more, and most of the production was from carbonate ores, although sulfide ores were mined in the deeper parts of the Black Forest, Nevada Lead, and Spruce Standard mines.

The primary ore minerals are argentiferous galena, chalcopyrite, bornite, and sphalerite. Oxide ore minerals are mainly cerussite, anglesite, malachite, chrysocolla, and lesser amounts of wulfenite, calamine, smithsonite, chalcocite, melaconite, and a yellow oxidized lead or antimony mineral. The silver content of the oxide ore is much higher than of the sulfides. Gangue minerals are quartz, calcite, and either pyrite, arsenopyrite, or limonite and manganese oxides.

The average grade of all the ore mined was about 11 percent lead, $12 \mathrm{oz}$ silver, and $0.01 \mathrm{oz}$ gold per ton, but some shipments of lead-silver ore contained 22 percent lead and $24 \mathrm{oz}$ silver per ton, and others about 40 percent lead and $15 \mathrm{oz}$ silver. Residual nodules of galena a few inches in diameter in the oxidized ore contain about 65 percent lead and a little silver. Copper ores averaged as much as 45 percent copper and $20 \mathrm{oz}$ silver per ton (Fourth of July mine). Zinc was recovered from ores containing 22 percent lead, 13 percent zinc, 5 percent manganese, 5 pencent iron, $4 \mathrm{oz}$ silver, and $0.005 \mathrm{oz}$ gold per ton (Granger and others, 1957, p. 143).

Scheelite occurs on the Atlantic claim disseminated in tactite and as pods or stringers in a granitic dike $80 \mathrm{ft}$ wide near its contact with the tactite for a distance of $160 \mathrm{ft}$. Samples assayed 0.5-2.0 percerit $\mathrm{WO}_{3}$ (A. C. Johnson and W. T. Benson, written commun., 1963).

Swales Mountain district

Location and history

\begin{tabular}{|c|c|c|c|c|c|}
\hline $\begin{array}{l}\text { Sections } \\
\text { (Approx.) }\end{array}$ & T. & $\begin{array}{l}\text { R. } \\
\text { E. }\end{array}$ & $\begin{array}{l}\text { Quadrangle name } \\
\text { ( } 7 \frac{1}{2} \text { or } 15 \text { minute) }\end{array}$ & . & • \\
\hline $\mathrm{S}_{\frac{1}{2}}^{1}$ & 36 & 52 & $\begin{array}{l}\text { Swales Mountain, } \\
\text { Swales Mountain NW }\end{array}$ & & \\
\hline $\mathrm{SW}^{\frac{1}{4}}$ & 36 & 53 & Swales Mountain & & \\
\hline $\mathrm{N}^{\frac{1}{2}}$ & 35 & 52 & $\begin{array}{l}\text { Swales Mountain NW, } \\
\text { Swales Mountain }\end{array}$ & & \\
\hline $\mathrm{NE}^{\frac{1}{4}}$ & 35 & 53 & Swales Mountain & & \\
\hline
\end{tabular}




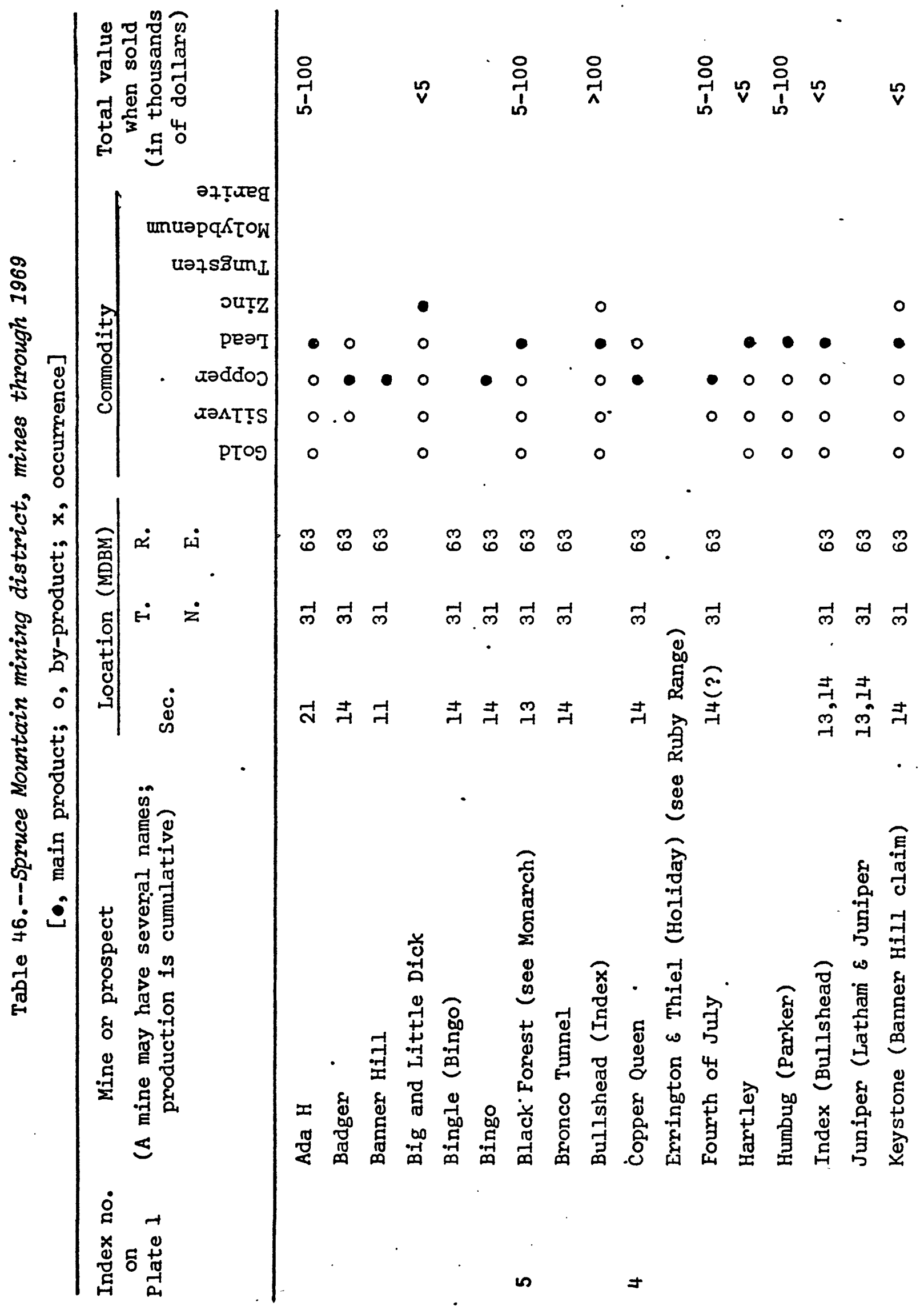




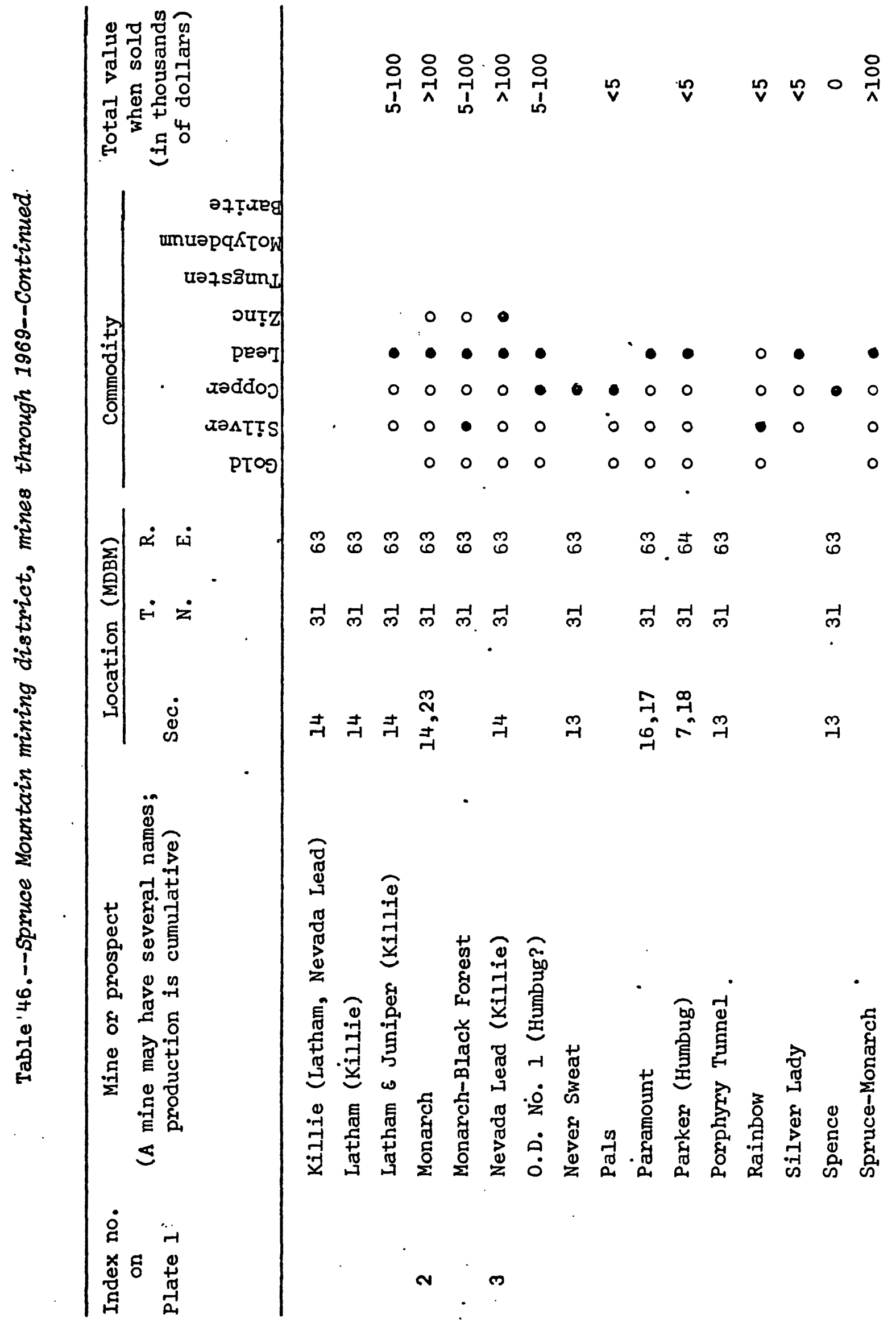




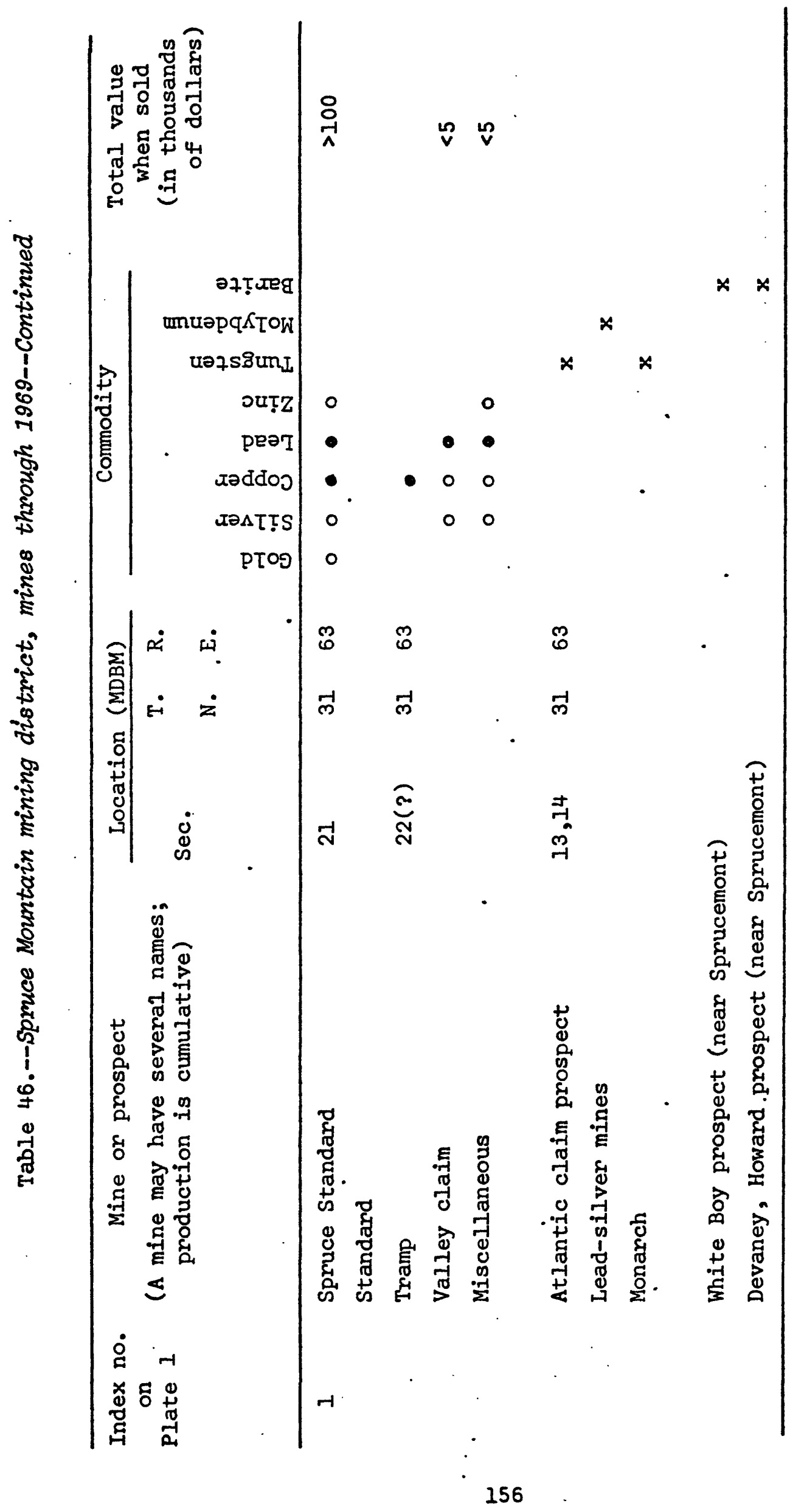


The Swales Mountain district includes Fish Creek Mountain and Swales Mountain at the south end of the Independence Mountains about 15 miles north of Carlin. Numerous gold and barite deposits have been explored, $\therefore$ but no production was recorded through 1969.

\section{Geologic setting and ore deposits}

Chert and shale strata about 4,700 ft thick of the Vinini Formation (western assemblage) of Ordovician age in the upper plate of three thrust faults of Mississippian or younger age overlie younger limestones (eastern assemblage) of Silurian (Roberts Mountains Formation), Devonian, and Mississippian ages which total more than 3,400 ft thick. The lower plate limestones are exposed only on the east slope of Swales Mountain in a fault window 2 miles long from north to south and about a mile wide. Both plates are intruded by irregular stocks, dikes, and sills of quartz porphyry, all of which are intruded by a stock and dikes of monzonite porphyry of Eocene to Oligocene age exposed within and outside the window. Large areas around Swales Mountain are covered by latite flows of EoceneOligocene age or by sandstones of Miocene-Pliocene age. Pleistocene fanglomerates and one Holocene landslide nearly a mile long are exposed along the east flank of the mountain (Evans and Ketner, 1971).

Numerous prospects, presumably of gold, in and near the window are nearly all in limestones of the lower plate near their contact with the monzonite porphyry, but a few are in the upper plate near thrust faults and at least one is in the intrusive.' Numerous pits and several shafts and adits were driven on narrow seams of iron oxides and residual pyrite.

- Three vertical holes core drilled in 1967 by the U.S. Geological Survey found only weakly anomalous zones of silver, lead, gold, molybdenum, mercury, and barite. Two of the holes were in limestones of the lower. plate, the other was collared in the upper plate, cut the Roberts Mountains(?) thrust, and bottomed in the lower plate (Ketner and others, 1968 , p. 5).

$\because$ Both plates, and the thrust fault that separates them, have been folded into a north-trending anticline which may have been caused by forcible emplacement of the intrusive rocks. Mineralized rock is exposed mainly along contacts of porphyry with upper plate chert and of monzonite with lower plate limestone. This geologic setting is similar to those of the gold deposits at the Carlin, Cortez, and Gold Acres mines (Ketner and others, 1968, p. 13).

Barite deposits of two genetic types, vein and replacement, on the west side of Swales Mountain in T. 35 N., R. 52 E., have been explored (Horton, 1963, p. 7, 8). At the Big Three (Chaliebois or Big Four?) prospect in sec. 2, veins of barite a few inches wide along a network of faults in shale and chert of the Vinini Formation were explored by numerous bulldozer cuts. At the Heavy Spar prospect in sec. 10, dark-gray sugary barite replacing silicified shale and chert of the Vinini Formation in an area $10 \mathrm{ft}$ wide and $330 \mathrm{ft}$ long was explored by four shallow bulldozer cuts. 
Tecoma district

Location and history

\begin{tabular}{llll}
\hline $\begin{array}{l}\text { Sections } \\
\text { (Approx.) }\end{array}$ & T. & $\begin{array}{l}\text { R. } \\
\text { N. }\end{array}$ & $\begin{array}{l}\text { Quadrangle name } \\
\left(7 \frac{1}{2} \text { or } 15 \text { minute }\right)\end{array}$ \\
\hline $1,12,13$ & 41 & 69 & Jackson Spring \\
$N-2 / 3$ & 41 & 70 & Jackson Spring \\
\hline
\end{tabular}

The Tecoma district includes an area about 4 miles square on the southern edge of the Goose Creek iills at an altitude of about 5,600 ft. Tecoma siding on the Southern Pacific Railroad is 9 miles south in Tecoma Valley.

The Jackson mine was discovered in 1906 (Hill, 1916, p. 104) and was a small, fairly steady producer during the years 1907-22 and 1948-55. Small shipments were made from the Star mine in 1932, the Desert Rat in 1937, and the Big Joe in 1941 (table 47). .

\section{Geologic setting and ore deposits}

In the Tecoma district, limestones, dolomites, shales, and quartzites ranging in age from Devonian to Permian are tilted $20^{\circ}-40^{\circ} \mathrm{NE}$, complexiy faulted, and intruded by small bodies of a porphyritic igneous rock of Early Pliocene(?) age exposed in surface pits and mine workings. Most of the faults strike north and dip either east or west; a few strike east and dip south. In the area of the Jackson mine, blue and gray limestore of Devonian age is silicified to jasperoid along two north-striking faults about 1,000 ft apart. The eastern jasperoid zone is about $200 \mathrm{ft}$ wide and several thousand feet long, the western zone is about $40 \mathrm{ft}$ wide, 500 ft long, and dips $45^{\circ} \mathrm{W}$. The ore bodies of the Jackson mine are in the westem zone of silicified limestone and do not extend into fresh limestöne, dolomite, or shale.

The ore bodies are veins along fractures that strike north and dip either east or west; most of the ore mined was from west-dipping fractures. The ore shoots range from 20 to 50 feet in length, 1 to $10 \mathrm{ft}$ in width, and have been mined to depths of $250 \mathrm{ft}$. Exploration at a depth of $365 \mathrm{ft}$ in 1953 was unsuccessful.

The ore minerals are mainly argentiferous cerussite and a few small pods of residual galena. Museum specimens of wulfenite on calcite were found in the upper workings of the Jackson(?) mine (Schilling, 1962a, p. 13). Gangue minerals include calcite, clay, iron oxides, quartz, and locally barite and halloysite. Oxidation is estimated to extend to a depth of about $500 \mathrm{ft}$. Average grade of shipments of screened ore during the $1950^{\prime} \mathrm{s}$ was about 17 percent lead, $4.2 \mathrm{oz}$ silver, and $0.01 \mathrm{oz}$ gold per ton, and 0.14 percent copper; some shipments also contained 0.85 percent $z i n c$. Some shipments of sorted, oxidized ore from the Queen of the West mine, which may be partly in Utah, contained 80 oz of silver per ton and as much as 18 percent zinc (Hill, 1916, p. 105). 


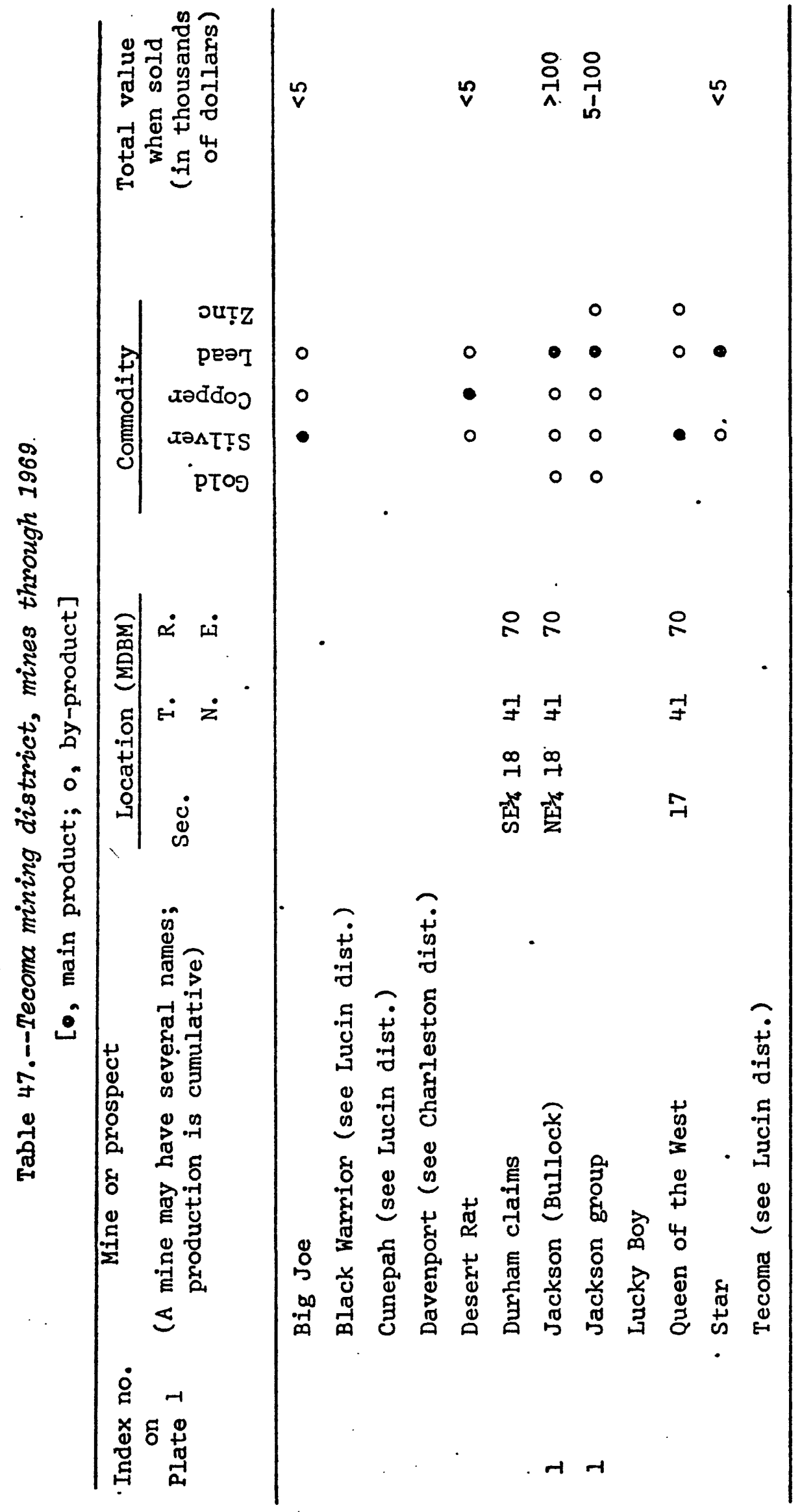


Tuscarora district

Location and history

$\therefore$

\begin{tabular}{|c|c|c|c|c|}
\hline $\begin{array}{l}\text { Sections } \\
\text { (Approx.) }\end{array}$ & $\begin{array}{l}\text { T. } \\
\text { N. }\end{array}$ & $\begin{array}{l}\text { R. } \\
\text { E. }\end{array}$ & $\begin{array}{l}\text { Quadrangle name } \\
\text { ( } 7 \frac{1}{2} \text { or } 15 \text { minute) }\end{array}$ & Remarks \\
\hline $\mathrm{SE}_{\frac{1}{4}}$ & 40 & 50 & Mount Blitzen & Prospects \\
\hline$S \frac{1}{2}$ & 40 & 51 & Mount Blitzen, Tuscarora & Principal silver mines \\
\hline 3 & 39 & 50 & Mount Blitzen & Berry Creek mercury mine \\
\hline$N-1 / 3$ & 39 & 51 & Mount Blitzen, Tuscarora & Original placer discoveries \\
\hline
\end{tabular}

The Tuscarora district was first organized to include only placer and lode gold deposits along and near McCann Creek, then enlarged to include the silver-gold mines in and north of the present town of Tuscarora, and now is considered to include also the mercury mine and prospects in the drainage areas of Berry and McCann Creeks.

Placer gold along McCann Creek and gold-bearing ledges nearby were discovered in 1867 (Browne, 1868, p. 429), but only the placers were worked until 1871 when the Young America claim was staked on a silver prospect in what is now the center of Tuscarora. The first shipments of silver ore were made in 1875, and although they averaged less than $\$ 30$ a ton, they stimulated prospecting which led to the discovery of bonanza silver ore at the Grand Prize mine in 1876 and to the Tuscarora Silver Rush of 1877.

- Production from the 15 largest mines and several smaller ones exceeded $\$ 1$ million in only 2 years, 1878 and 1879 , and declined to less than $\$ 152,000$ in 1881 (Nolan, 1936, p. 12). The Navajo mine accounted Eor a revival of production in 1884, the Commonwealth in 1890, and the Dexter from 1897 to 1904 , but most of the declining production since 1905 was from the Dexter dumps and tailings. No production of silver has been reported since 1963.

Placer production in the early days probably did not exceed 36,000 oz (Johnson, 1973, p. 97) and total production of all metals--silver, gold, lead, copper, and mercury--through 1969 was $\$ 10,715,651$.

Production figures for the district (table 5) include 12 tons of mercury ore which yielded two flasks of mercury valued at $\$ 519$ from the Berry Creek and Silverado mines during the 1950's. No production of metals was reported from the district from 1964 through 1969.

\section{Geologic setting}

The oldest rock unit exposed in the district is quartzite and black chert of the Valmy Formation of Ordovician age. It is poorly exposed about $200 \mathrm{ft}$ north of the northwest comer of the Found Treasure No. 2 claim (Nolan, 1936, p. 17), and well exposed north of the district. The quartzite-chert unit is overlain by bedded andesite breccias and tuffs with interbedded andesite lava flows which are all light colored and total about 5,000 ft thick. These light-colored rocks are intruded by a large stock northwest of the district and by many irregular bodies 
of dark-greenish andesite of Oligocene(?) age. The intrusive andesite bodies are as much as half a mile wide and a mile long. They trend generally northward and are of indeterminate dip, although one chilled $\therefore$ border dips $65^{\circ} \mathrm{W}$. (Nolan, 1936, p. 20). Overlying the igneous rocks along the lower southeast slopes of Mount Blitzen, alluvial gravels of Quaternary age as much as $30 \mathrm{ft}$ thick cap erosion surfaces of the andesites.

The bedded andesites are regionally tilted $15^{\circ}-50^{\circ} \mathrm{E}$. or SE., are steeply domed around the intrusive plug, and are cut by shear zones which trend east or northeast and dip steeply. They are also locally fracturec or jointed along zones that trend eastward and dip northward at low angles. Both the shear zones and the fracture zones are locally mineralized.

The intrusive andesites are cut by three sets of faults; one set strikes a few degrees west of north and dips west, another set strikes nearly east and dips northward, and the third set strikes northeast and dips northwest. Faults of the first two sets are locally mineralized and those of the third are postmineral normal faults of small displacement.

\section{Ore deposits}

Ore deposits of four different kinds have been mined in the distri=:: gold-bearing stockworks in the bedded andesites, silver-rich lodes mosi: $\because$ in the intrusive andesites, mercury deposits in the bedded andesites, $a=\dot{.}$ gold placers in the gravel capping. Rutile and other titanium minerals are primary constituents universally present in the bedded andesites in noncommercial amounts. One specimen contained 0.4 percent $\mathrm{TiO}_{2}$.

Most of the silver ore contains gold, and in some of the silver losies there are separate gold ore shoots. Similarly, the gold deposits conta: by weight more silver than gold. These relationships suggest that the composition of the mineralizing solutions changed progressively with tirne, and that during the mineralizing process different channelways were open at different times.

Alteration is a notable feature of the district. Both the bedded and the intrusive andesites exhibit two types of alteration, an earlier chloritization (propylitization) and later adularization (Nolan, 1936, p. 24 ). Chloritization is peripheral to the adularia alteration. In the chlorizized areas the original minerals of the andesite are replaced by chlorite, albite, calcite, pyrite, and sericite. Adularization is most intense near the centers of mineralization; silicification and bleaching of the beddec andesites is so widespread by the addition of quartz, adularia, and clay minerals that the rock has been classed as rhyolite (Emmons, 1910, p. 59). Smaller amounts of apatite and sericite are common:. In the bedded andesites, which are more permeable, both kinds of alteration are intense and widespread; in the more dense intrusive andesites, alteration is restricted to sporadic adularization of the wallrocks in the immediate vicinity of the lodes. Adularization has been dated at $38 \mathrm{~m} . \mathrm{y}$. (M. L. Silberman and E. H. Mckee, written commun., 1974). 


\section{Gold deposits}

The gold deposits are stockworks along fracture zones that trend

$\therefore$ eastward and dip northward at low angles in adularized bedded andesite extending from the southern edge of Tuscarora southwestward to Beard Hill.

The largest gold deposit was at the Dexter mine just south of Tuscarora where a highly fractured or jointed zone 1,400 ft long and $200 \mathrm{ft}$ wide was mined to a depth of $300 \mathrm{ft}$. The fractures strike in all directions and contain many closely spaced veinlets of quartz and adularia. Free gold is deposited in drusy cavities in the veinlets and also replaces altered andesite. Small pockets of rich ore containing as much as $\$ 300$ a ton in gold occur in a few places, but the average grade was about \$3.50 a ton in gold and silver. The weight-ratio of gold to silver in the products recovered was about $I: 1$ for bullion and $1: 12$ for cyanide precipitates (Nolan, 1936, p. 33). The silver content of the gold deposits evidently was so dispersed that very little secondary enrichment occurred.

\section{Silver-rich deposits}

The silver-rich ore bodies are veins along the northwest- and eaststriking faults in the intrusive andesites. Veins along the northweststriking faults comprise a westerly belt that was mined in the liavajo, Belle Isle, North Belle Isle, Commonwealth, and North Commonwealth mines. These veins were the most productive in the district. An easterly belt of mines along the east-striking faults includes the Independence, DeFrees, Grand Prize, and Argerita. In these mines the best ore shoots pitched northward along intersections of fissures. In both belts the ore shoots were a few inches to a few feet wide and had a relatively small vertical range. No figures are available for stope lengths. The deepest shaft, the Grand Prize, was $750 \mathrm{ft}$ deep, but most of the ore came from above the 320-foot level. Except on the Navajo claim the ore shoots did not crop out, and the Grand Prize bonanza was first exposed at a depth of $40 \mathrm{ft}$.

$\because$ Ore minerals in the upper portions of the shoots below the leached zone and above the water table, which was about $100 \mathrm{ft}$ below the surface, consisted largely of secondary cerargyrite and native silver. Emmons (1910, p. 60) reported: "A single block of horn silver from the Commonwealth mine is said to have sold for $\$ 30,000 . "$ Much of the ore mined, however, contained primary argentite, stephanite, proustite, pyrargyrite, enargite, bornite, chalcopyrite, sphalerite, galena, and gold in a gangue of quartz, calcite, pyrite, arsenopyrite, and altered wallrock.

Grade of the silver-rich ore mined in the early years commonly ranged from $\$ 50$ to $\$ 350$ a ton, but in later years ore was milled that averaged as little as $\$ 6.30$ for an entire year. Average value per ton throughout the life of 10 of the principal mines ranged from $\$ 29$ for the Commonwealth to $\$ 107$ for the Navajo. The silver-gold ratio of the silver-rich deposits was about 150:1, although recorded production from many of the mines indicates that the greater value of the ore was in gold (table 48). 


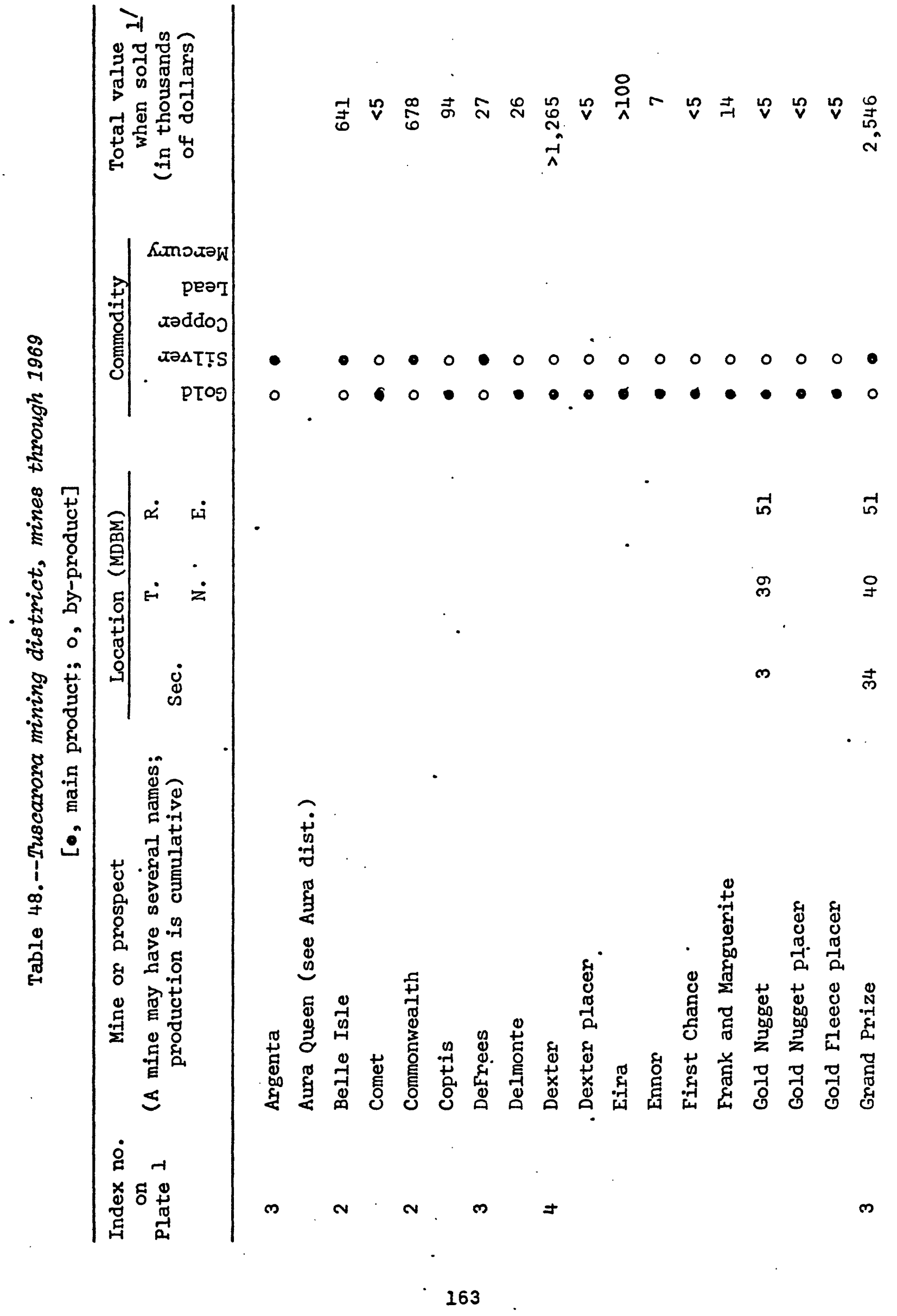




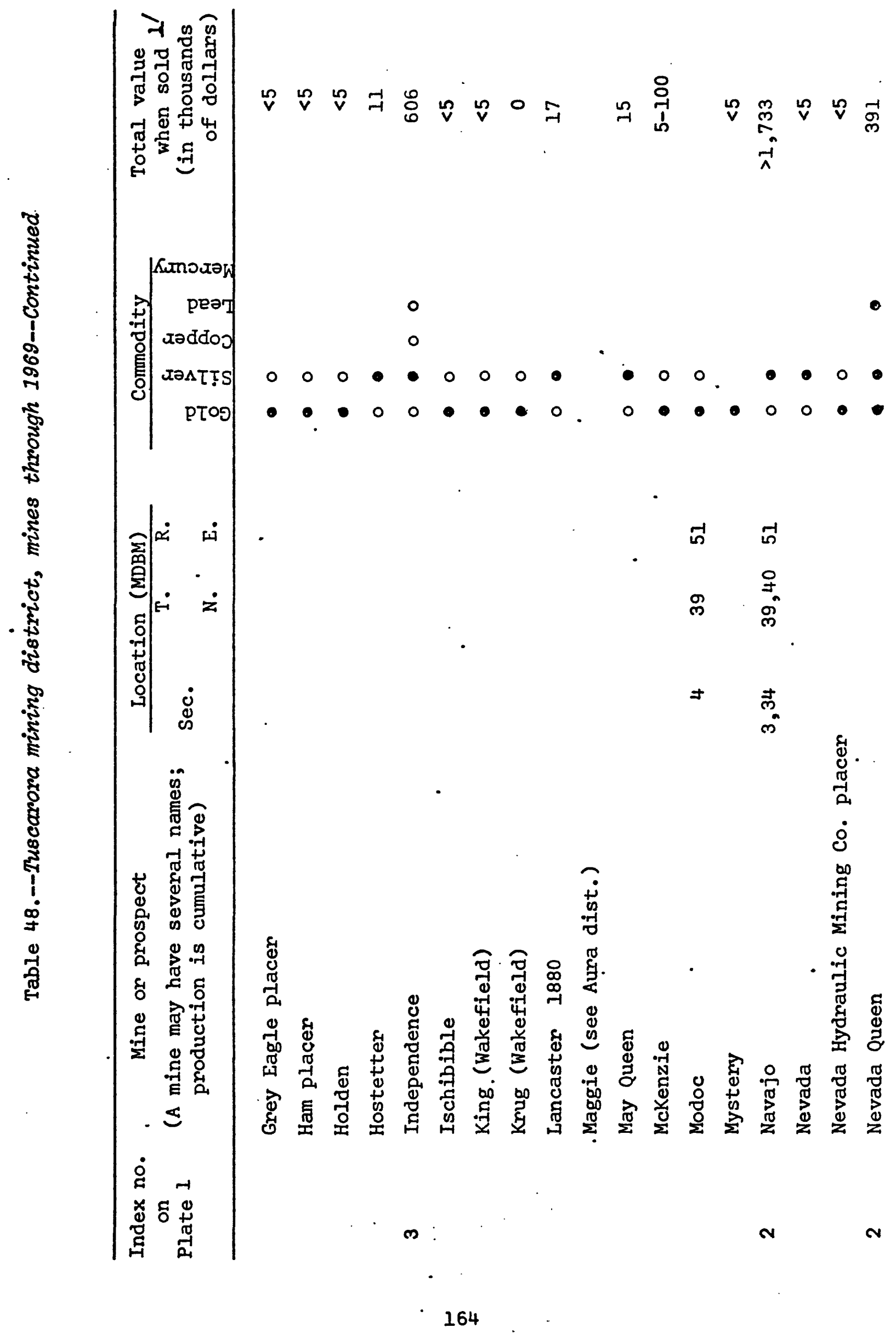




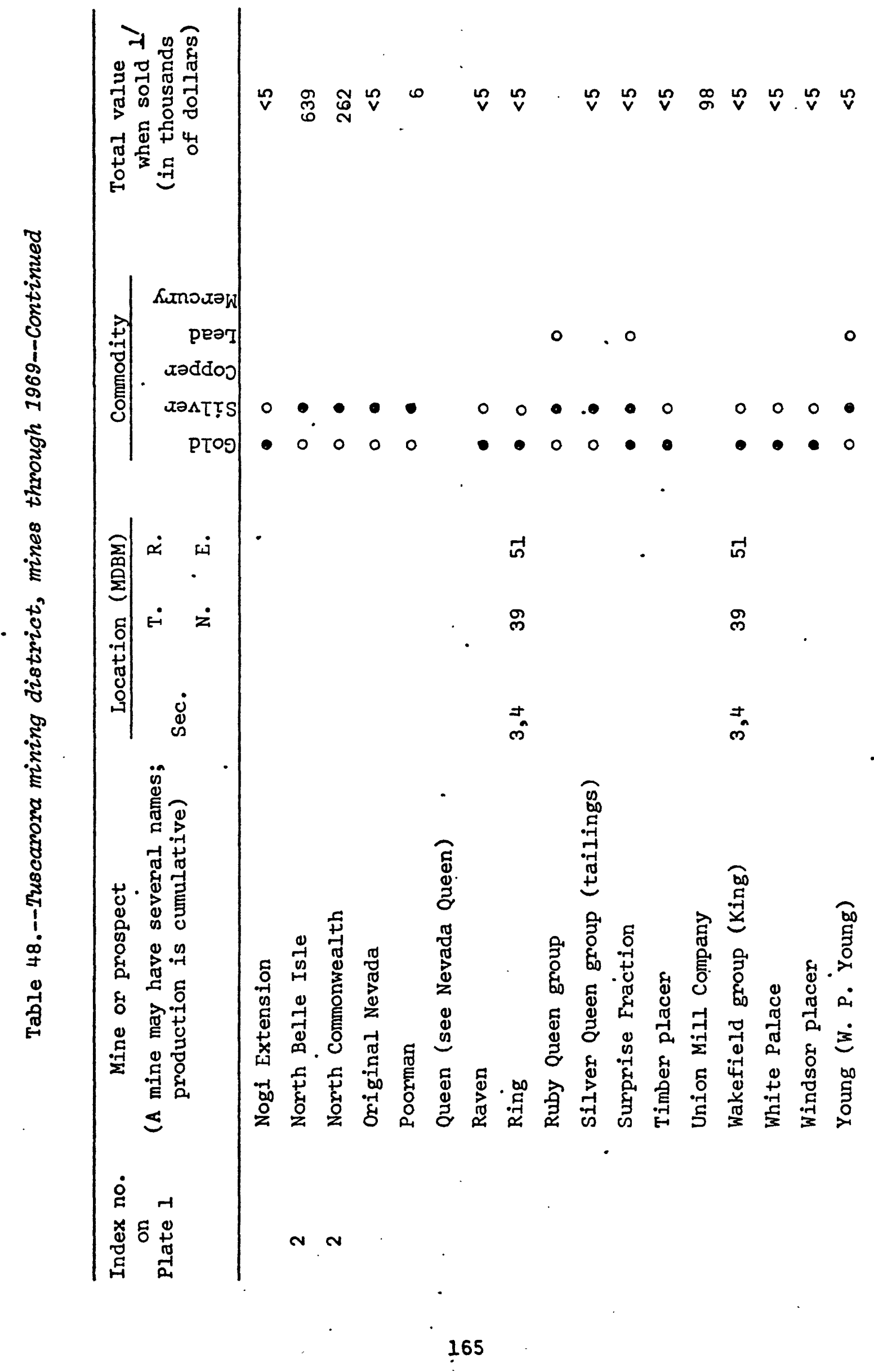




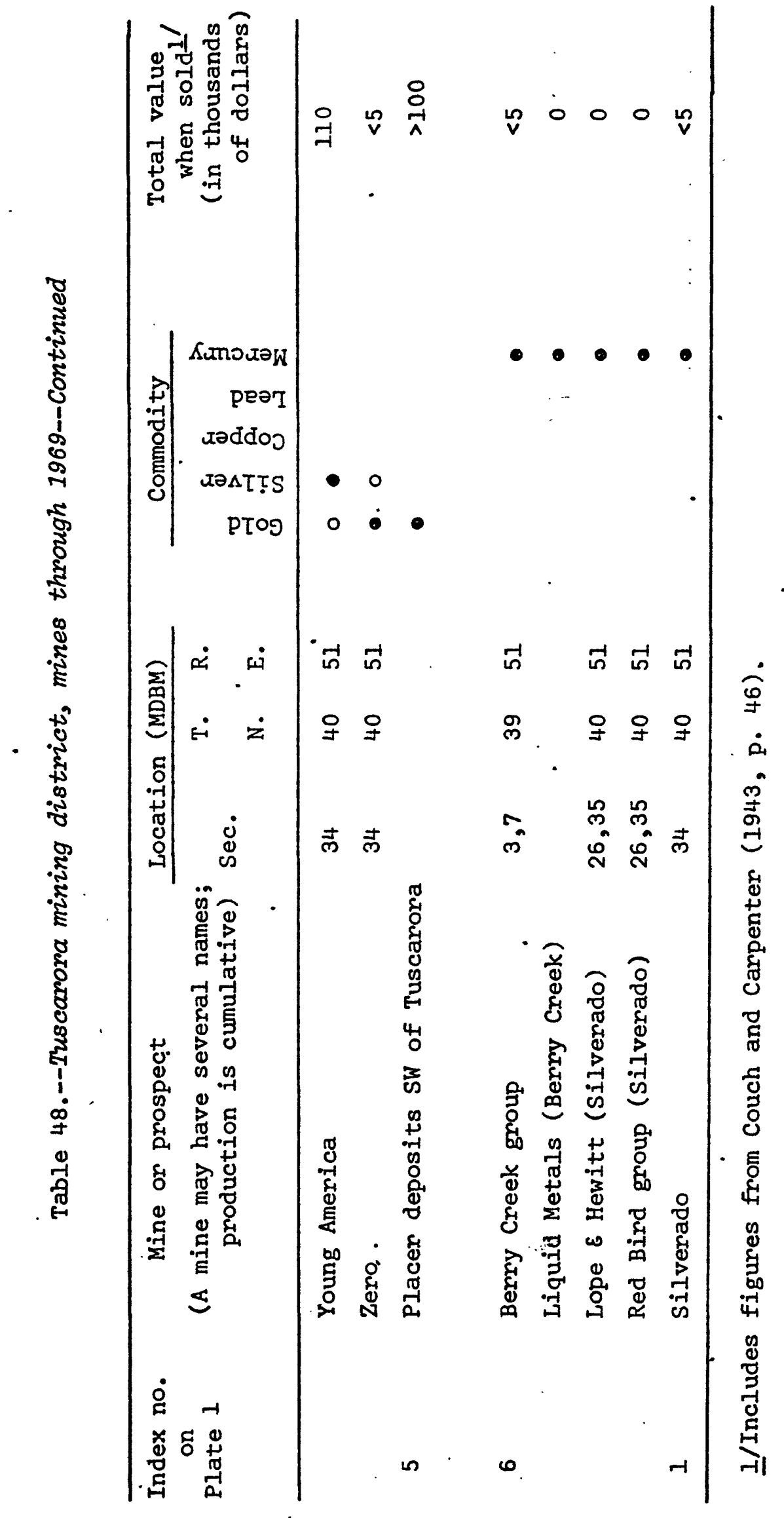


Mercury deposits

The two mercury deposits in the district consist of veinlets and dis-

$\therefore$ seminated crystals of cinnabar along steep fracture zones in altered andesite (Bailey and Phoenix, 1944, p. 64, 65). At the Berry Creek mine a shear zone that strikes northeast and dips $70^{\circ} \mathrm{SE}$. contains cinnabar in veinlets up to an inch thick along the zone, and disseminated crystals and smaller veinlets in the walls. Gangue minerals are chalcedony, quartz, pyrite, and marcasite.

At the Red Bird (Silverado) mine a shear zone along a contact of footwall andesite with hanging wall tuff strikes N. $78^{\circ} \mathrm{W}$. and dips steeply southward. The andesite for a width of about $5 \mathrm{ft}$ contains disseminated cinnabar, native mercury, and pyrite, and also cinnabar and quartz in small veinlets at right angles to the shear.

Grade of the ores is not known, but they were worked only briefly in 1955 and 1958 when the price of mercury was $\$ 290$ and $\$ 230$ a flask.

\section{Gold placers}

Placer golc was found only in the area of the primary gold deposits from Tuscarora to Beard Hill, about 3 miles west, in the alluvial gravels that cover an area of 2 square miles or more to a depth of a few inches to $30 \mathrm{ft}$. Gold was recovered from dry stream beds that cross the area as well as from gravel and soil between the stream beds. The gold particles range in size from dust to nuggets weighing more than an ounce. Emmons (1910, p. 62) reported that a large number of samples from potential - dredging ground in this area averaged about $14 \xi$ per cubic yard (gold at $\$ 20.67$ per troy oz).

Union district

Location and history

\begin{tabular}{lllll}
\hline $\begin{array}{l}\text { Sections } \\
\text { (Approx.) }\end{array}$ & $\begin{array}{l}\text { T. } \\
\text { N. }\end{array}$ & $\begin{array}{l}\text { R. } \\
\text { E. }\end{array}$ & $\begin{array}{l}\text { Quadrangle name } \\
\left(7 \frac{1}{2} \text { or } 15 \text { minute) }\right.\end{array}$ \\
\hline $31,32,33$ & 27 & 53 & Mineral Hill, Railroad Pass Eureka and Elko Counties \\
NW $\frac{1}{4}$ & 26 & 53 & Mineral Hill, Railroad Pass Eureka and Elko Counties \\
\hline
\end{tabular}

Although part of the workings of the Beil lead-silver mine are in Elko County, Land Office and production records are listed under Eureka County. A geologic map and description of the district are in Roberts and others (1967). 
Valley View district

Location and history

\begin{tabular}{lllll}
\hline $\begin{array}{l}\text { Sections } \\
\text { (Approx.) }\end{array}$ & $\begin{array}{l}\text { T. } \\
\text { N. }\end{array}$ & $\begin{array}{l}\text { R. } \\
\text { E. }\end{array}$ & $\begin{array}{l}\text { Quadrangle name } \\
\left(7 \frac{1}{2} \text { or } 15 \text { minute) }\right.\end{array}$ & Other district names, remarks \\
\hline$W_{\frac{1}{2}}$ & 29 & 58 & Franklin Lake NW & $\begin{array}{c}\text { Ruby Range district, Dawley } \\
\text { Canyon and Hankins Canyon areas }\end{array}$ \\
& & & Franklin Lake SW & .
\end{tabular}

The Valley View district includes Mica, Dawley, Hankins Creek, and Road Canyons north of Harrison Pass on the east șlopes of Green Mountain, the southernmost of two peaks by that name along the crest of Ruby Mountains.

Native bismuth and scheelite were discovered in Road Canyon in 1913 (Hill, 1916, p. 62), and later an unsuccessful attempt was made to deveio? the tungsten deposits (Hess and Larsen, 1921, p. 246).

In 1928 the first of about 55 mining claims were staked in secs. 1 $\hat{E}$, $17,20,21,28$, and 29 covering numerous pegmatite dikes containing mic and beryl. Two dikes in Dawley Canyon were explored for mica by a $D: \tau$ $12 \mathrm{ft}$ deep and an adit $30 \mathrm{ft}$ lon 5 . Other dikes were explored primar: $i \mathrm{y}$ for beryl by a few cuts and a siont adit. A little beryl was produce $i$, mainly for specimens and metallungical tests. About 250 lb of trimmec sheet mica was shipped in 1944.

The tungsten deposits were restaked in 1943, and $20^{\circ}$ tons of sorved ore containing 150 units of $\mathrm{WO}_{3}$ was shipped from the Owl claim of the Valley View property. No further production has been reported through 1969.

Geologic setting

The Valley View district covers the east-central part of an intrusive complex in the Harrison Pass area of the Ruby Mountains. Other parts are covered by the Ruby Valley, Gilbert Canyon, Corral Creek, and Harrison Pass districts.

The intrusive complex estends westward 10 miles across the full widtn of the range, and northward 18 miles from Rattlesnake Mountain to Rattlesnake Creek. Its mairgins include Precambrian schists, Cambrian Prospect Mountain quartzite, Cambrian limestones, and Ordovician Pogonip limestones and shales, all of which are intruded by a series of four granitic stocks, by many pegmatite dikes of three different ages, and by aplite dikes related to the youngest stock which is named the Harrison Pass stock.

oldest of the three unnamed intrusives is an irregular stock about 3 miles wide and 10 miles long of biotite-muscovite granite of Jurassic age that forms the summit and much of the east slope of the range opposite Frankl in Lake. A second stock about 5 miles wide and 7 miles long of pegmatitic granite also of Jurassic age forms the west slope. The thind stock about a mile wide of muscovite-biotite granite of Cretaceous age 
age crops out discontinuously for 6 miles along the lower east slope opposite Franklin Lake. The fourth, youngest, and largest pluton is the Harrison Pass stock about 7 miles wide and 10 miles long of granodioritequartz monzonite of Tertiary age that extends almost completely across.

$\therefore$ the range south of the older stocks.

Pegmatite dikes as much as $55 \mathrm{ft}$ wide and 2,200 ft long occupy north-trending fractures that dip steeply east in the granites or along the schistosity or bedding in the metamorphic rocks. The oldest dikes are genetically related to the Jurassic granites, others to the Cretaceous granite, and the youngest--some of which cut the Harrison Pass stock--to the Tertiary intrusive.

Aplite dikes are neither as large nor as abundant as the pegmatites. They are related to the Tertiary (Harrison Pass) stock, and occupy northtrending fractures in the schists, the older granites, and in the pegmatites. Within about $1,500 \mathrm{ft}$ of the stocks, and along the pegmatite dikes, the sedimentary rocks are locally metamorphosed to quartz mica schist, marble, or lime silicate zones.

\section{Ore deposits}

In the Dawley Canyon area of the Valley View district, mica was mined from two pegmatite dikes 6-10 ft wide and $300 \mathrm{ft}$ long. The best showing was in a pit $12 \mathrm{ft}$ deep where sheets and books $3-6$ inches square comparativel: free of blemishes constitute 10-20 percent of the rock, but other dikes contain only about 3 percent muscovite, most of which would be classed as scrap mica (Olson and Hinrichs, 1960, p. 158).

- Beryl was found in nearly a third of the 350 or more pegmatite dikes in the Dawley Canyon area. It occurs as sparse white, green, and azure crystals up to 3 inches in diameter. The dikes are commonly zoned from the walls inward. Coarse-grained pegmatitic zones may contain 0.5 percent beryl; aplitic zones are lower grade. Analyses of 12 samples ranged from 0.001 to 0.10 percent BeO (Olson and Hinrichs, 1960, p. 160). Beryl also occurs in schistose layers of the Cambrian and Precambrian rocks, where graÿ to white crystals up to $1 \frac{1}{2}$ inches long have been found ( $R$. W. Kistler, oral commun., 1973).

In Road Canyon, layers an inch to a foot wide of tactite more or less altered to chlorite are found along the margins of lenticular sills of quartz monzonite as much as $15 \mathrm{ft}$ wide and $75 \mathrm{ft}$ long in white crystalline limestone. At the valley View property, scheelite in crystals up to half an inch across occur in the tactite. On the Owl claim, scheelite ore was mined from a tactite layer $1-6$ inches wide for $48 \mathrm{ft}$ along the strike in an open cut and an adit. The ore was estimated to range in grade from 1 to 5 percent $\mathrm{WO}_{3}$ (M. R. Klepper, written commun., 1943). Bismuthinite and native bismuth occur with small crystals of pyrite in a gangue of quartz, rutile, phlogopite, and pyroxene near the centers of some of the sills (Hill, 1916, p. 63). 


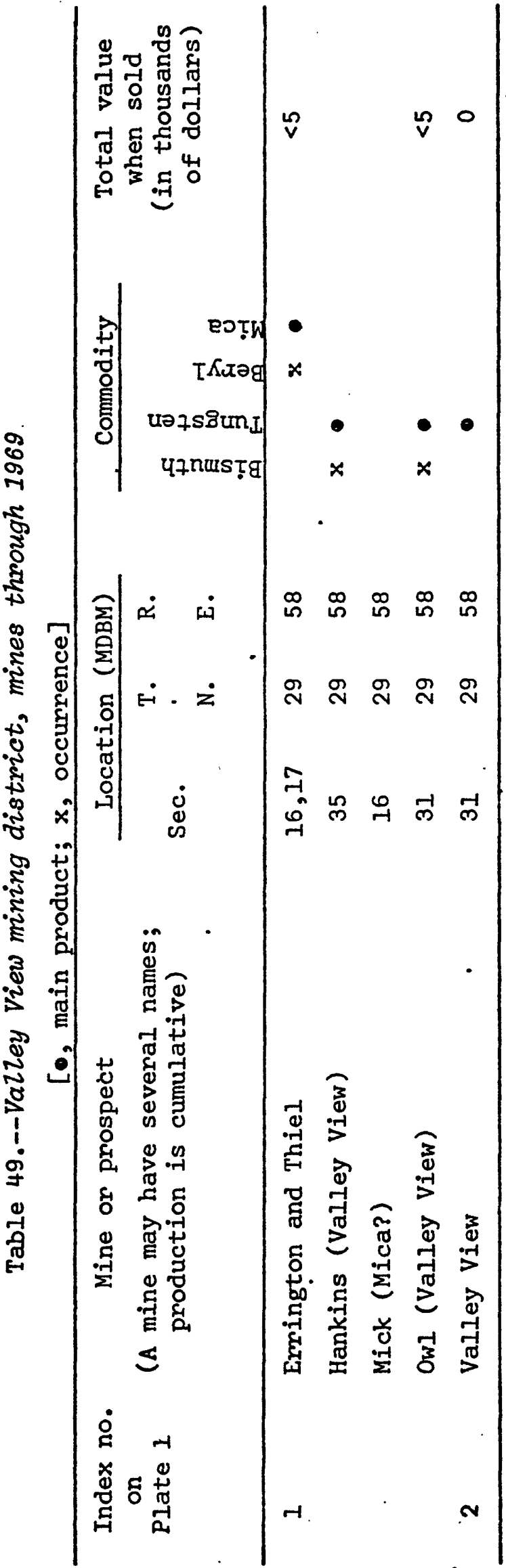


Warm Creek district

\begin{tabular}{lllll}
$\begin{array}{l}\text { Sections } \\
\text { (Approx.) }\end{array}$ & $\begin{array}{l}\text { T. } \\
\text { N. }\end{array}$ & $\begin{array}{l}\text { R. } \\
\text { E. }\end{array}$ & Quadrangle name & Other district names \\
\hline $\begin{array}{lllll}14,15,22, \\
23,26,27\end{array}$ & 33 & 61 & Elko $2^{\circ}$ & Polar Star, Clover Valley
\end{tabular}

The Warm Creek district includes the southeast slopes of Warm Creek Ridge at the south end of the East Humboldt Range, south of Warm Spring Creek and west of Clover Valley. The Polar Star group of claims was staked in 1912 ( $\mathrm{Hill}, 1916$, p. 60), and all of the zinc production from the district (table 5) came from the Polar Star mine during the years

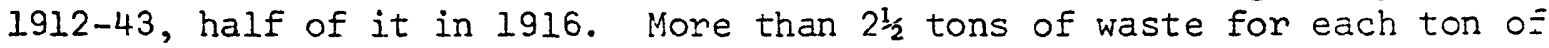
ore was also mined. The Silver Cliff mine yielded 43 tons of lead-silver ore during the period 1927-42. There is no record of production for the years $1944-69$.

U.S. Bureau of Mines records are listed under Spruce Mountain district for the year 1912, under Warm Creek district thereafter. Land Office records are listed under "Unknown-unnamed-unorganized mining districts."

The unnamed district in T. 34 N., R. 61 E., listed by Lotz (1934, p. 18) should probably be included in the Warm Creek district, although the type and location of the implied prospects is not known.

\section{Geologic setting and ore deposits}

Eureka Quartzite and overlying dolomites and limestones of Ordovician and Devonian ages exposed on the east flank of the range are in thrustfault contact with and overlain by limestones, shales, and conglomerates(?) of .Permian and Triassic ages exposed on the summit and west side of the rànge.

The zinc ore bodies at the Polar Star mine are irregular replacenent deposits in brecciated limestones of Paleozoic age. The limestones are shattered, bleached, and recemented for $350 \mathrm{ft}$ or more along three persistent faults that strike east and dip $50^{\circ}-60^{\circ} \mathrm{S}$. in an area $120 \mathrm{ft}$ wide. Pods and stringers of carbonate ore were mined from stopes as large as 20 by 50 by $8 \mathrm{ft}$ to depths of about $60 \mathrm{ft}$ where the water table was encountered. Both lead and zinc were recovered from the early shipments, but from most of the ore, only zinc (23-26 percent) was recovered. Ores from the Silver Cliff mine contained about 18 percent lead, 11 oz silver per ton, 0.9 percent copper, and a trace of gold. 


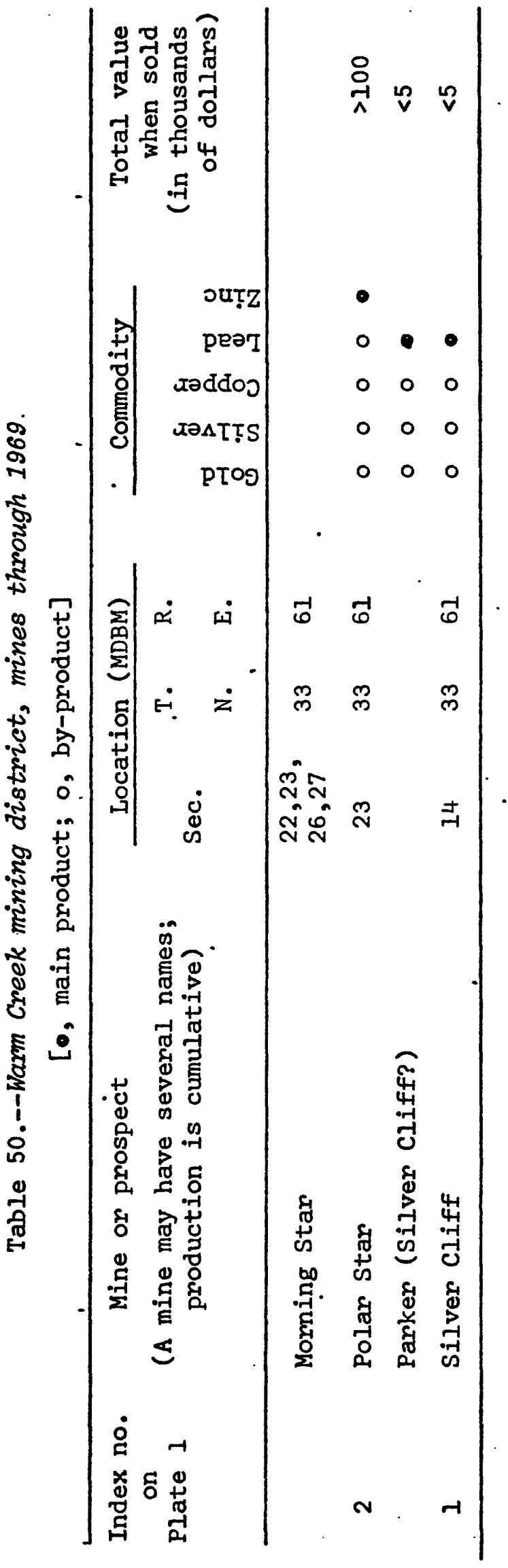


Wells district

Location and history

Other district names

Sections T. R. Quadrangle name

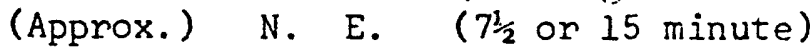

All 3862 Metropolis, Oxley Peak Humboldt Wells

Al1 $37 \quad 62$ Welcome, Wells

The Wells district includes the low hills surrounding Oxley Peak 7 miles north of Wells and others on both sides of Clover Valley about 5 miles south of Wells.

Production of gold was reported for 1916 and 1925 (Couch and Carpenter, 1943, p. 41, 46), of sandstone (Nevada Picture Rock) for later years, and 50 tons of tungsten ore in 1956 (Southern Pacific Co., 1964, p. 128, 114). The tungsten deposits were further explored in 1970 (U.S. Bur. Mines, 1970, p. 1126). Marble, in beds 300-200 ft thick, and deposits of limestone, chert, and quartzite conglomerate (decorative) are also reported by Southern Pacific Co. (1964, p. 127-131).

Geologic setting and ore deposits

The tungsten deposits in sec. 31, T. $37 \mathrm{~N} .$, R. 62 E., are in CambrianOrdovician limestones with thin quartzite and biotite schist interbeds in the upper plate of a thrust fault that emplaced them on Prospect Mountain Quartzite. The limestone sequence is tilted variously southwest to northwest and is cut by a few quartz veinlets along and across the bedding and by bedding-plane faults. At the largest of several tungsten deposits, scheelite occurs in fractures along and across the bedding in limestone and also in quartz veinlets in a zone $15 \mathrm{ft}$ or more thick below a beddingplane fault marked by a few inches of sheared biotite schist and a little quartz. The deposit is explored by a 9-by 15-foot adit about $100 \mathrm{ft}$ long, and"by six or more vertical drill holes from the surface above and beyond the face of the adit. Some areas in the adit appear by ultraviolet light to contain about 1 per cent $\mathrm{WO}_{3}$. A lower adit leading to 20-50-foot drifts exposes scheelite and beryllium minerals in a tactite zone $6 \mathrm{ft}$ thick that dips $30^{\circ}-45^{\circ} \mathrm{SW}$. in calcite mylonite. Production of 50 tons reported by the Southem Pacific Co. (1964, p. 114) averaged 2.11 percent $\mathrm{WO}_{3}$.

Nevada Picture Rock, used locally for facing stone and for carving into bowls and other decorative objects, was mined from numerous pits, quarries, and cuts as much as $50 \mathrm{ft}$ long, $10 \mathrm{ft}$ wide, and $20 \mathrm{ft}$ deep. The rock consists of friable sandstone and porous siltstone of Tertiary age in beds one-fourth of an inch to a foot or more thick that strike northeast and dip $30^{\circ}-40^{\circ} \mathrm{SE}$. They are jointed in all directions; unbroken slabs measuring 3 by $8 \mathrm{ft}$ are about the largest obtainable. The rock contains limonite rings or is uniformly stained rust red, yellow, or purple. 


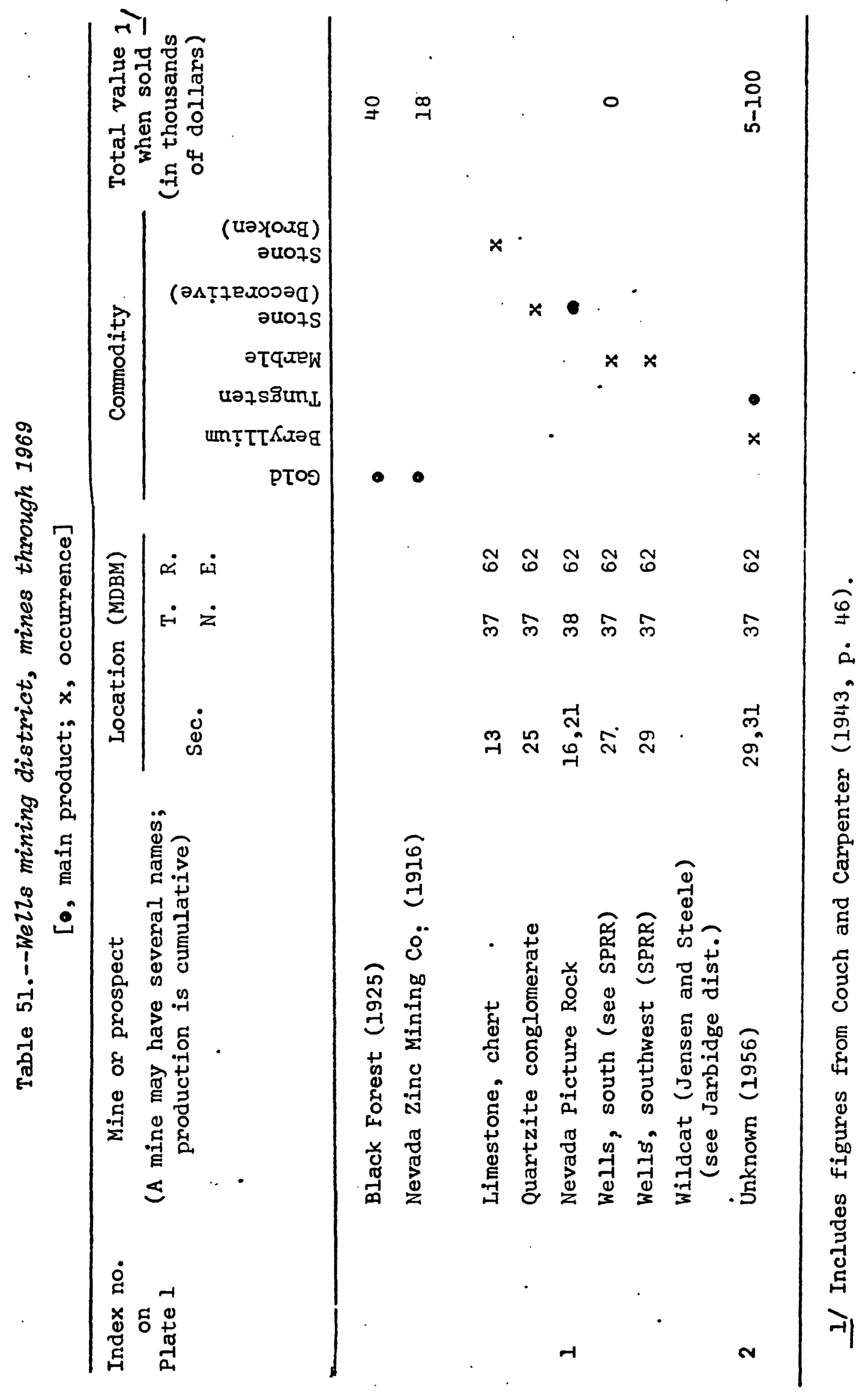


Wendover. district

Location and history

\begin{tabular}{|c|c|c|c|c|}
\hline $\begin{array}{l}\text { Sections } \\
\text { (Approx.) }\end{array}$ & $\begin{array}{l}\text { T. } \\
\text { N. }\end{array}$ & $\begin{array}{l}\text { R. } \\
\text { E. }\end{array}$ & $\begin{array}{l}\text { Quadrangle name } \\
\text { ( } 7 \frac{1}{2} \text { or } 15 \text { minute) }\end{array}$ & Remarks \\
\hline All & 33 & 70 & Shafter 1 SE & Prospects \\
\hline$N \frac{1}{2}$ & 32 & 70 & & Stone quarry \\
\hline
\end{tabular}

The Wendover district includes the south slopes of Leppy Peak, north of Wendover, and hill 5275, 6 miles south of Wendover.

Four lode mining claims on the slopes of Leppy Peak were patented on several prospects in secs. 10 and 15, T. $33 \mathrm{~N} ., \mathrm{R} .70 \mathrm{E}$, , but no production has been recorded.

Decorative stone was quarried on hill 5275 in sec. 18, T. 32 N., R. $70 \mathrm{E}$. The rock was evidently crushed and screened. Production may have been a few hundred tons.

Tungsten ore was mined during 1953 at the Great Western mine (location unknown) and about 7 units of $\mathrm{WO}_{3}$ was recovered from 10 tons of sorted ore.

The adit shown on the quadrangle map in sec. 3, T. 33 N., R. 70 E., is a natural limestone cave about $100 \mathrm{ft}$ below the Lake Bonneville level.

Geologic setting and ore deposits

Leppy Peak consists mainly of limestone and dolomites ranging in age from Devonian to Permian. The sedimentary rocks are tilted westward and cut by a network of faults, most of which strike N. $10^{\circ}-30^{\circ} \mathrm{W}$. Around the foothills of Leppy Peak the sedimentary rocks are overlain by patches of Jarbidge(?) rhyolite of Tertiary age, and by sediments of somewhat younger Tertiary age. In the southern part of the district, hill 5275 is composed of typical coarse-grained Jarbidge rhyolite overlain by a flow of mediumgrained rhyolite. Much of the coarse-grained rhyolite throughout an area of several acres on the lower west side of the hill is attractively stained bright green by ferric iron. The stone quarry is within this area.

White Horse district

Location and history

\begin{tabular}{|c|c|c|c|}
\hline $\begin{array}{l}\text { Sections } \\
\text { (Approx.) }\end{array}$ & $\mathrm{T}$ & $\begin{array}{l}\text { R. } \\
\text { E. }\end{array}$ & $\begin{array}{l}\text { Quadrangle name } \\
\left(7 \frac{1}{2} \text { or } 15 \text { minute) }\right.\end{array}$ \\
\hline All & 28 & 68 & Elko $2^{\circ}$, Ferguson Springs $1 \mathrm{SW}$ \\
\hline$W-1 / 3$ & 28 & 69 & \\
\hline$N-1 / 3$ & 27 & 68 & \\
\hline
\end{tabular}




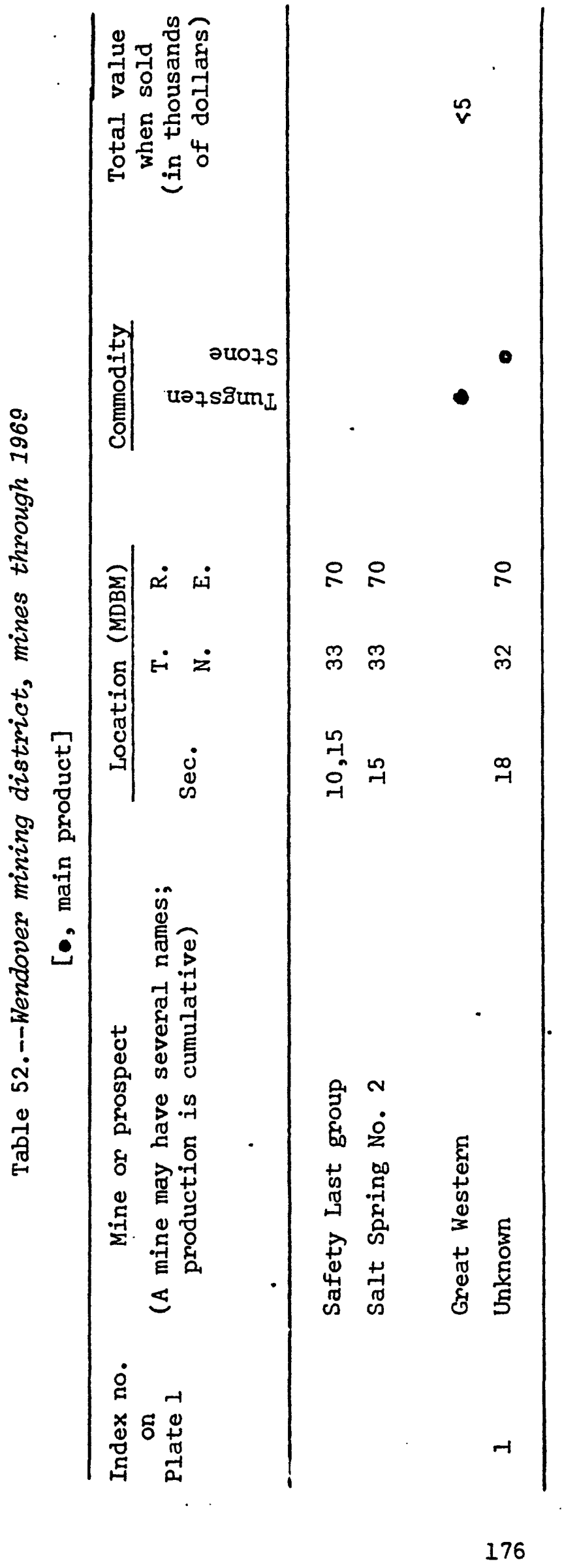


The White Horse district covers White Horse Mountain and Sugar Loaf Peak in the Goshute Mountains--a southward continuation of the Toano Range-south of White Horse Pass (U.S. Highway 50), formerly known as Don Don Pass.

A little copper and lead may have been produced sometime before 1913 (Hill, 1916, p. 98) and 12 tons of tungsten ore containing 28 short-ton units of $\mathrm{WO}_{3}$ was shipped during 1942-43. Lead-silver-zinc production is recorded for the years 1948-49 (table 5).

\section{Geologic setting and ore deposits}

Limestones of the Guilmette and Devils Gate Formations of Devonian age are intruded by a stock of quartz monzonite about 3 miles across. Near the stock the limestones are metamorphosed to tactite. The stock is cut by two sets of nearly vertical joints--a north-striking set and an eastwardstriking set--and by sheeted zones of fractures that dip gently eastward.

Two types of ore bodies were mined, vein deposits and contactmetamorphic deposits. Narrow quartz veins along some of the east-dipping fractures in the quartz monzonite contain copper and lead carbonates, chrysocolla, limonite, and a little residual pyrite and chalcopyrite. The veins were explored to depths of $50 \mathrm{ft}$ (Hill, 1916, p. 98). Lead-silverzinc ore presumably occurs in similar veins. In the contact-metamorphic deposits, scheelite occurs disseminated erratically in extensive bodies of tactite composed of gamet, epidote, and quartz along a contact between limestone and granitic rock. Sorted ore from the only body of commercial grade found contained about 2.3 percent $\mathrm{WO}_{3}$ (D. M. Lemmon, written commun., 1948).

\section{GUIDE TO EXPLORATION}

Prospectors risk their time and money against long odds. Their chance for success, according to a time-honored approximation, is--if they find anything at all--that 1 out of 10 mineral showings will be worth a little work, 1 out of 10 workings yill result in a prospect, and 1 out of 10 prospects will make a mine 1 . The production records of Elko County confirm the last part of that approximation. Of the 531 mines from which production is recorded, 53, or almost exactly 10 percent, produced more than $\$ 100,000$. While there are no records of the number of workings that failed, 358 of the remaining producers yielded less than $\$ 5,000$. No figures are available on the costs of these small producers, but settlement sheets from custom smelters commonly indicate a gross revenue of a few percent more than direct mining cost; the preliminary costs of prospecting, exploring, and developing are lost. For these small producers, it is probable that more money went into the ground than came out. Elko County is not unique in this respect; it applies the world over. Even at the Comstock lode which produced $\$ 400$ million, during its first 6 years and. $\$ 50$ million of production, the "mines as a whole had failed to show a

1/"Mining has been defined as 'the art or practice of operating mines profitably.' Until a mineral deposit may be worked with profit it is merely a prospect." (Hoover, 1933, p. I). 


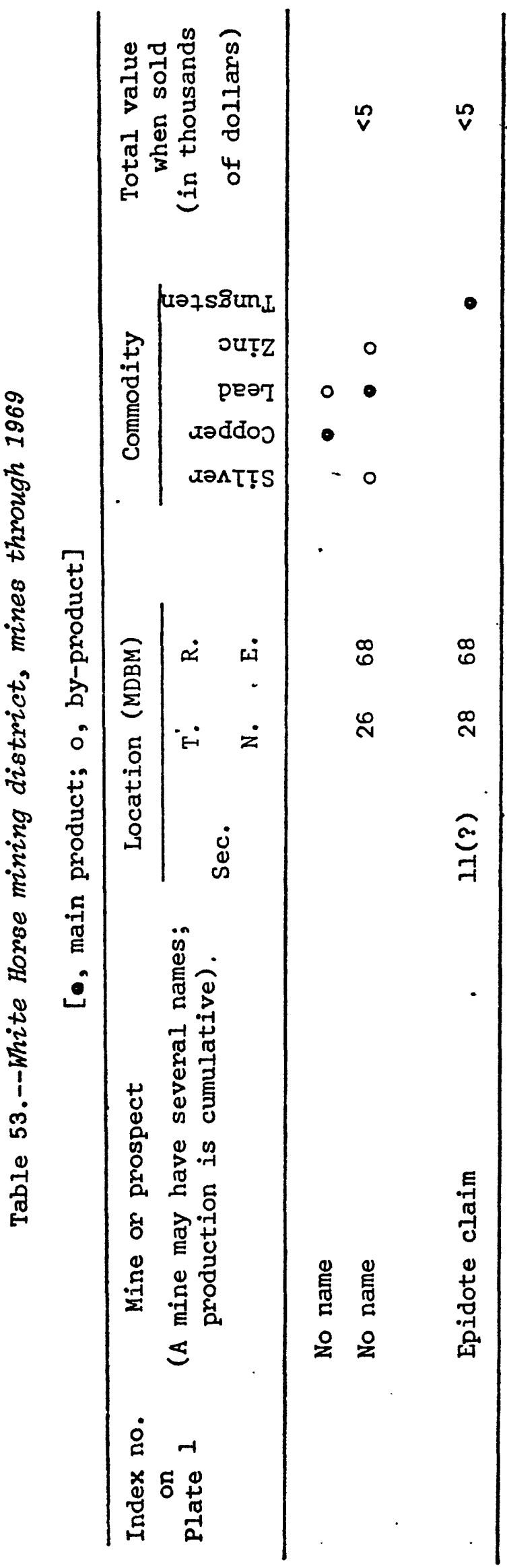




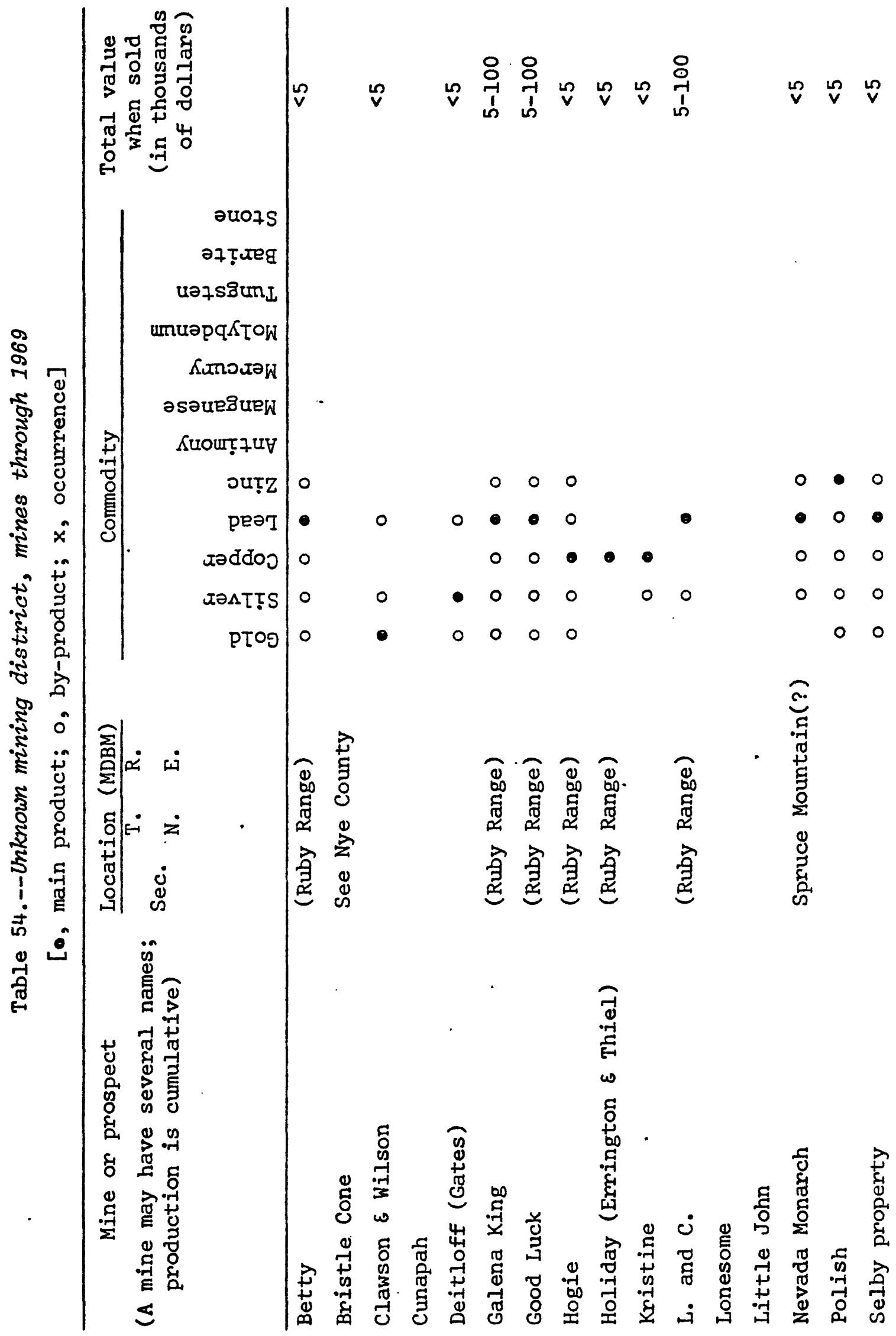




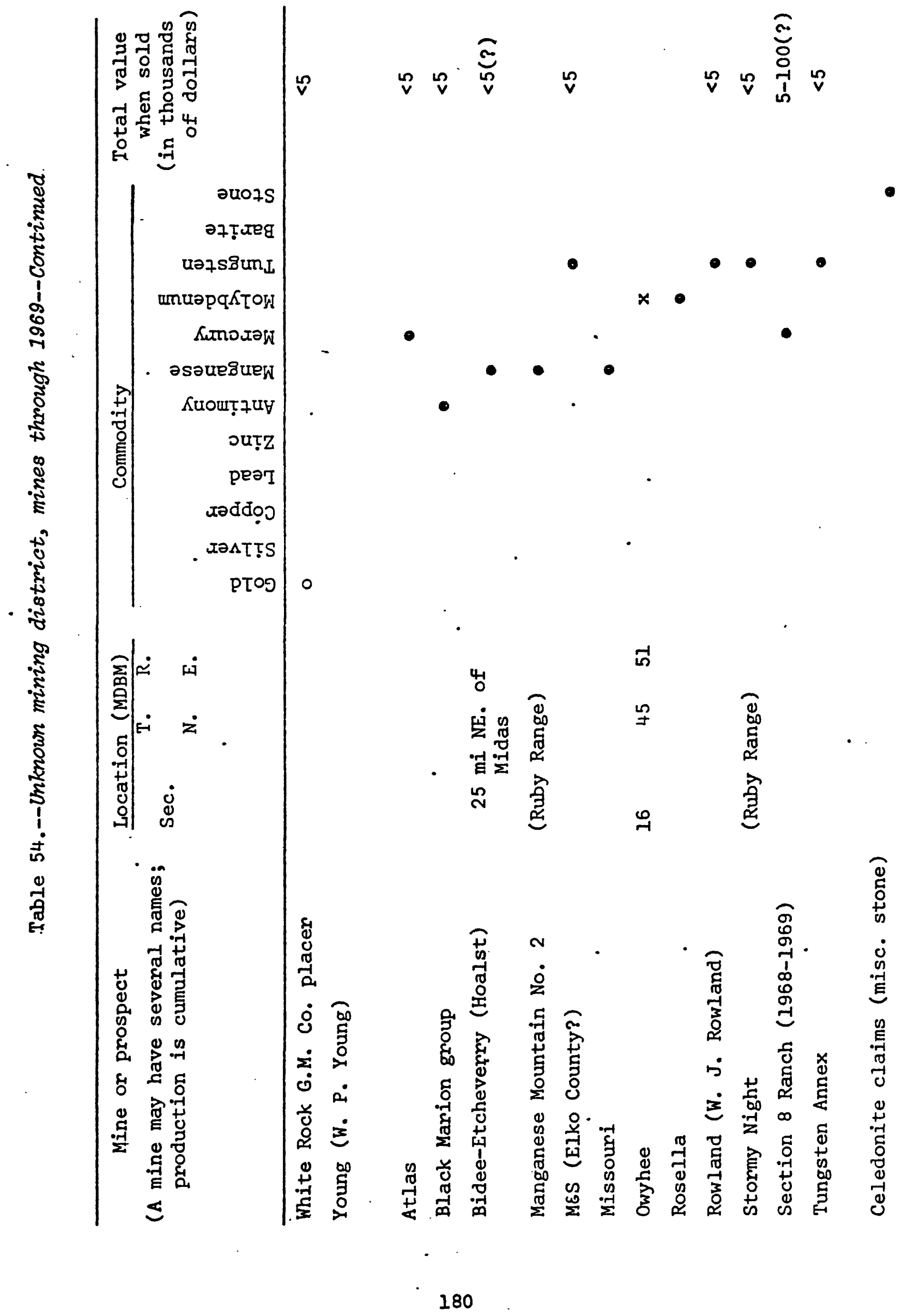




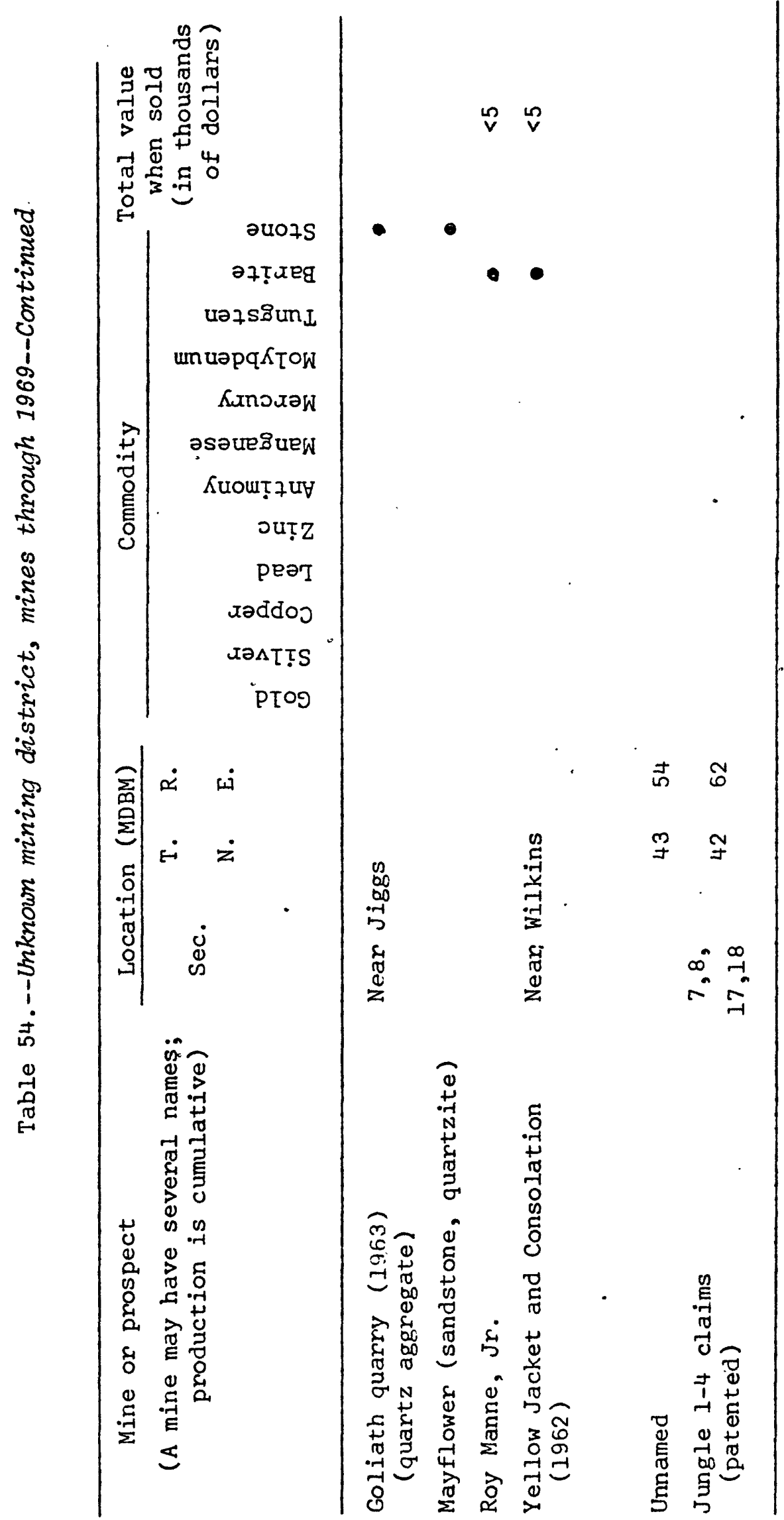


profit--in fact had entailed a loss" (Smith, 1943, p. 58). The miner's loss, however, is the world's gain, for mankind's material standard of living is proportional to his use of minerals. Elko County has contributed 19 different mineral commodities worth over $\$ 90,563,000$.

$\therefore \quad$ The foregoing statistics resulted from prospecting methods of the past, when the old Cornish saying "Every fruit has its blossom" referred to gossans or even to outcrops of ore. Newer and better equipment has now largely replaced the old--ultraviolet lamps, Geiger counters, seismometers, gravity meters, electrical and electromagnetic sensors, mercury "sniffers," and satellite or airborne cameras, magnetometers, and scintillation counters can now detect "blossoms" that were invisible to the old-timers. Some of these devices even "see" into the ground and detect subsurface anomalies. By "seeing" to greater depths, modem equipment appears to have kept the prospector's risk to about the same level as it was in the days of "grassroots" discoveries--one chance in a thousand.

The most used, and possibly still the most useful guide to exploration is "Look for elephants in elephant country." While this guideline does not preclude the search of new areas, its applicability is confirmed by the mere face of mining districts and metallogenic provinces. The reasons for districts and provinces are not fully known, but the following observations and speculations may serve as additional guides.

Metallic ore deposits in most districts in Elko County are in or near granitic stocks; in other districts concealed stocks can logically be inferred. The proximity of most ore deposits to intrusive rocks is assumed to connote a genetic relationship, either direct or indirect. Recent work by Coats, Marvin, and Stern (1965) and by Coats and Mckee (1972) led them to imply that the relationship is indirect. They found that 15 of the plutons in Elko County are of three age groups, Jurassic, Cretaceous, and Tertiary, and that most of them are elongate either east-west or north-south in conformity with the deep-seated grain of the region. They observed that a northerm belt of stocks is sparsely mineralized whereas in other east-west belts gold, silver, copper, lead, zinc, tungsten, or antimony is the dominant metal at stocks of all three ages, although not all of these metals are found in the vicinity of any one pluton. On a countywide basis, ore bodies mined primarily for gold have been found only north of the latitude of Elko, and antimony only north of Tuscarora. They concluded that the factor that determines the dominant metal in the ore seems to be not the age or composition of the pluton but its geographic location.

An apparent exception to this conclusion is the common relationship of disseminated chalcopyrite to quartz monzonite porphyry. Even here, however, the relationship may be one of mutual dependency, the controlling factor not age or composition but location. The quartz monzonite composition, the porphyritic texture, and the copper content may all result from the same fortuitous combination of source area and a depth of emplacement so shallow that copper sulfide crystallizes while most other metals escape to the surrounding wallrock. Nevertheless, in Elko County, stocks composed of quartz monzonite or quartz monzonite porphyry are of Cretaceous or Tertiary age; none is Jurassic. 
The foregoing conclusion suggests that within metallogenic provinces there are metallogenic zones, within which metalliferous deposits are localized wherever a heat source such as a pluton, and a conduit such as a

$\therefore$ fault system, coincide in time. The metals deposits in each zone may depend on a zoned metal content of oceanic sediments or oceanic crust subducted beneath the margins of the continental plate and distilled out only in the locality of a heat source that generates a hydrothermal system (Bailey and others, 1973, p. 411).

In the following localities in Elko County, deposits of various types appear to have unexplored potential:

1. All valleys

Because the plutons and the ore deposits associated with them were emplaced before the present valleys were formed by Basin-Range faulting, the bedrock under the valley fill may contain about the same proportion of plutons and ore bodies as the ranges. If so, then more than half the ore bodies in the county are yet to be found, since more than half the area-about 56 percent--is covered by alluvium, two-thinds of which is less than 1,000 ft thick (Archbold, 1972).

\section{Burner district}

The Mint vein in an andesite flow probably continues downward into sedimentary rocks and may intersect a replaceable limestone stratum.

3. Cornucopia district

Geologic mapping by Coats (1967, p. 2) revealed that the ridge south of the mine shafts ( $W \frac{1}{2}$ sec. 19 ) is postmineral rhyolite on the downdropped side of a fault that separates it from the older mineralized andesite exposed in the mine area. The thickness of the rhyolite is not known, but under it the buried upper surface of the andesite may be only a few scores of feet below the ground surface. The concealed andesite may contain other veins or faulted continuations of the known veins (Coats, 1967, p. 4 ).

4. Delker district

The West Buttes and Delker quartz monzonite stocks are porphyritic in many places. Copper was mined from contact metamorphic deposits in 1 imestone at West Buttes. The east-west alinement with the porphyry copper deposit in the Dolly Varden district suggests a deep-seated zoned relationship.

\section{Elko district}

In the southern Adobe Range (secs. 3,5, 8, and 10, T. 34 N., R. 54 E.), parts of the Diamond Peak Formation are somewhat altered and slightly enriched in copper and silver. Although aeromagnetic Iines give no indication of a concealed intrusive, further geochemical prospecting is advisable (Ketner, 1970, p. B108).

In the Peko Hills some samples of float contained about 20 percent $\mathrm{P}_{2} \mathrm{O}_{5}$. (Low-grade ore contains 24 percent or more.) The phosphatic beds appear from the float to be thin, but their actual thickness and extent could be determined by trenching (Ketner, 1970, p. B108). 


\section{Lime Mountain district}

Copper-zinc-silver deposits along steep faults are in Cambrian lime$\therefore \quad$ stone that overlies slates and phyllites equivalent to the Pioche Shale. If the phyllites contain interbedded limestone equivalent to the Combined Metals Member in the Pioche district, the intersections of the faults with that limestone may contain replacement deposits.

\section{Mountain City district}

Decker (1962, p. 56) observed that placer gold deposits along Trail Creek (T. 44 N., R. 53 E.) in the Aura district and along Van Duzer Creek (T. $45 \mathrm{~N} .$, R. $53 \mathrm{E}$.) in the Mountain City district appear to be spatially related to an exposed surface of the Roberts Mountains thrust fault.

\section{Owyhee Desert area}

In the northwest corner of the county, the Cenozoic formations "may yet yield significant commercial quantities of petroleum" (Decker, 1962, p. 57). The Elko Formation and equivalents throughout the county have numerous porous clastic beds and abundant oil shales in its lower member. In Bull Run Basin (Aura district) a well drilled in 1957 found continuous shows of oil between 1,522 and 2,150 ft. Pre-Cenozoic rocks in Elko County are less favorable; Mississippian, Permian, and Triassic formations contain relatively thin petroleum source beds.

9. Swales Mountain district

The following suggestions are quoted from Ketner and others (1968, p.13):

"The presence of small gold deposits in the upper plate rocks at Swales Mountain suggests the possibility of more extensive deposits in the Roberts Mountains Formation where it lies concealed by upper plate rocks or in the broken rock along subsurface parts of the Roberts Mountains thrust. Exploratory efforts therefore should include drilling through the upper plate in areas immediately surrounding Swales Mountain. Unfortunately there is no way of knowing how deep the thrust zone lies or how far below the thrust the Roberts Mountains Formation lies. Both could be very close to the surface without revealing their presence in any way.

"Lower plate rocks intruded by igneous rocks are concealed beneath alluvium on the east flank. of the mountain (secs. 4, 9). Exploration of these rocks would require drilling through the alluvium east of the area where lower plate rocks are exposed." 


\section{Twin Buttes area}

At the Twin Buttes, 10 miles north of Deeth (Twin Buttes quadrangle), two stocks, one on each butte and each about a quarter of a mile long, are intrusive into an exposure half a mile wide of sedimentary rocks of the Western facies. These are the only stocks that large in the county where St mines or prospects have not been found, but the surrounding area is covered by Tertiary sediments and Quaternary alluvium that may conceal unknown mineral concentrations.

\section{Valley View district}

Beryl crystals up to $1 \frac{1}{2}$ inches long are common in some of the schistose layers of the Cambrian and Precambrian rocks in the igneousmetamorphic complex (R. W. Kistler, oral commun., 1973).

\section{SELECTED REFERENCES}

Archbold, N. L., 1972, Modified geologic map of Nevada: Nevada Bur. Mines and Geology Map 44.

Bailey, E. H., Clark, A. L., and Smith, R. M., 1973, Mercury, in Brobst, D. A., and Pratt, W. P., eds., United States mineral resources: U.S. Geol. Survey Prof. Paper 820, p. 401-414.

Bailey, E. H., and Phoenix, D. A., 1944, Quicksilver deposits in Nevada: Nevada Univ. Bull., v. 38, no. 5, Geology and Mining Ser. 41, 206 D.

Beal, L. H., 1963, Investigations of titanium occurrences in Nevada: Nevada Bur. Mines Rept. 3, 42 p.

Blue, D. M., 1960, Geology and ore deposits of the Lucin mining district, Box Elder County, Utah, and Elko County, Nevada: Utah Univ., Salt Lake City, M.S. thesis.

Bowen, C. F., 1913, Lignite in the Goose Creek district, Cassia County, Idaho: U.S. Geol. Survey Bull. 531, p. 252-262.

Browne, J. R., 1868, Report on the mineral resources of the States and Territories west of the Rocky Mountains: Washington, U.S. Treasury

$\div$ Dept., $674 \mathrm{p}$.

Bushnell, Kent, 1967, Geology of the Rowland quadrangle, Elko County, Nevada: Nevada Bur. Mines Bull. 67, 38 p.

Butler, B. S., Laughlin, F. G., and Heikes, V. C., 1920, Ore deposits of Utah: U.S. Geol. Survey Prof. Paper 11l, 670 p.

Buwalda, J. P., 1923, Nevada, in Winchester, D. E., Oil shale of the Rocky Mountain region: U.S. Geol. Survey Bull. 729, p. 91-102.

Cathcart, J. B., and Gulbrandsen, R. A., 1973, Phosphate deposits, in Brobst, D. A., and Pratt, W. P., eds., United States mineral resources: U.S. Geol. Survejy Prof. Paper 820, p. 515-525.

Coash, J. R., 1967, Geology of the Mount Velma quadrangle, Elko County, Nevada: Nevada Bur. Mines Bull. 68, 20 p. 
Coats, R. R., 1964, Geology of the Jarbidge quadrangle, Nevada-Idaho: U.S. Geol. Survey Bull. 1141-M, 24 p.

1967, Economic significance of revised age relations of rocks in the Comucopia mining district, Elko County, Nevada: U.S. Geol. Survey Circ. 549, 4 p.

Coats, R. R., Marvin, R. F., and Stern, T. W., 1965, Reconnaissance of mineral ages of plutons in Elko County, Nevada, and vicinity, in Geological Survey research 1965: U.S. Geol. Survey Prof. Paper 525-D, p. DII-DI5.

Coats, R. R., and McKee, E. H., 1972, Ages of plutons and types of mineralization, northwestern Elko County, Nevada, in Geological survey research 1972: U.S. Geol. Survey Prof. Paper 800-C, P. C165-C168.

Coats, R. R., and Stephens, E. C., 1968, Mountain City Copper mine, Elko County, Nevada, in Ridge, J. D., ed., Ore deposits of the United States, 1933-1967 (Graton-Sales volume), v. 2: New York, Am. Inst. Mining Metall. Petroleum Engineers, p. 1074-1101.

Collinson, J. W., 1968, Permian and Triassic biostratigraphy of the Medicine Range, northeastern Nevada: Earth Sci. Bull., v. 1, no. 4, p. $25-44$.

Couch, B. F., and Carpenter, J. A., 1943, Nevada's metal and mineral production: Nevada Univ. Bull., v. 37 [38], no. 4, Geology and Mining Ser., $159 \mathrm{p}$.

Crittenden, M. D., Jr., 1963, New data on the isostatic deformation of Lake Bonnevilie: U.S. Geol. Survey Prof. Paper 454-E, P. El-E3l.

Davidson, D. F., and Lakin, H. H., 1962, Metal content of some black shales of the western conterminous United States, in Geological Survey research 1962: U.S. Geol. Survey Prof. Paper 450-C, p. C74.

Davis, H. C., 1954, Summary report of reconnaissance and exploration for uranium deposits in northem Nevada: U.S. Atomic Energy Comm.

$\because \quad$ RME-2013, 23 p.

Decker, R. W., 1962, Geology of the Bull Run qudarangle, Elko County, Nevada: Nevada Bur. Mines Bull. 60, 65 p.

Eakin, T. E., 1960, Ground-water appraisal of Newark Valley, White Pine County, Nevadà: Nevada Dept. Conservation Nat. Resources, Groundwater Resources, Reconn. Ser. Rept. 1, 33 p. 196la, Ground-water appraisal of Long Valley, White Pine and Elko Counties, Nevada, Nevada Dept. Conservation Nat. Resources, Groundwater Resources, Reconn. Ser. Rept. 3, 35 p.

196lb, Ground-water appraisal of Pine Valley, Eureka and Elko Counties, Nevada: Nevada Dept. Conservation Nat. Resources, Ground-water Resources, Reconn. Ser. Rept. 2, 41 p. 
1962a, Ground-water appraisal of Diamond Valley, Eureka and Elko Counties, Nevada: Nevada Dept. Conservation Nat. Resources, Groundwater Resources, Reconn. Ser. Rept. 6, 60 p.

$\therefore \quad$ 1962b, Ground-water appraisal of Independence Valley; western Elko County, Nevada: Nevada Dept. Conservation Nat. Resources, Groundwater Resources, Reconn. Ser. Rept. 8, 31 p.

Eakin, T. E., and others, 1951, Contributions to the hydrology of [Ruby and Railroad Valleys] eastern Nevada: Nevada State Engineer's Office, Water Resources Bull. 12, 171 p.

Eakin, T. E., Hughes, J. L., and Moore, D. 0., 1967, Water-resources appraisal of Steptoe Valley, White Pine and Elko Counties, Nevada: Nevada Dept. Conservation Nat. Resources, Water Resources, Reconn. Ser. Rept. 42,48 p.

Eardley-Wilmot, V. L., 1928, Diatomite, its occurrence, preparation, ard uses: Canada Dept. Mines, Mines Branch Pub. 691, 182 p.

Emmons, W. H., 1910, A reconnaissance of some mining camps in Elko, Lander, and Eureka Counties, Nevada: U.S. Geol. Survey Bull. 408, $130 \mathrm{p}$.

Evans, J. G., and Ketner, K. B., 1971, Geologic map of the Swales Mountain quadrangle and part of the Adobe Summit quadrangle, Elko County, Nevada: U.S. Geol. Survey Misc. Geol. Inv. Map I-667, 1 sheet.

Fournier, R. O., and Truesdell, A. H., 1973, An empirical Na-K-Ca geothermometer for natural waters: Geochim. et Cosmoschim. Acta, v. 37, p. $1255-1275$.

Garside, L. J., 1974, Geothermal exploration and development in Nevada through 1973: Nevada Bur Mines Rept. 21, 12 p.

Gilbert, G. K., 1875, Report upon the geology of portions of Nevada, Utah, California, and Arizona examined in the years 1871 and 1872: U.S. Geog. and Geol. Explor. W. 100th Mer. (Wheeler): U.S. Govt. Printing $\because$ Office 1889, 8a., v.3 Geology, 681 p., pt. 1, p. 21-187.

Glancy, P. A., 1968, Water-resources appraisal of Butte Valley, Elko and White Pine Counties, Nevada: Nevada Dept. Conservation Nat. Resources, Water Resources, Reconn. Ser. Rept. 49, 50 p.

Granger, A. E., Bell, M. M., Simmons, G. C., and Lee, Florence, 1957, Geology and mineral resources of Elko County, Nevada: Nevada Bur. Mines Bull. 54, $190 \mathrm{p}$.

Gulbrandsen; R. A., 1966, Chemical composition of phosphorites of the Phosphoria Formation: Geochim. et Cosmochim. Acta, v. 3, p. 769-778.

Hague, Arnold, and Emmons, S. F., 1877, Descriptive geology: U.S. Geol. Survey 40th Parallel (King), v. 2, $890 \mathrm{p}$. 
Hess, F. L., and Larsen, E. S., 1921, Contact-metamorphic tungsten deposits of the United States: U.S. Geol. Survey Bull. 725-D (1922), p. 245-309.

$\therefore$ Hill, J. M., 1912, The mining districts of the western United States: U.S. Geol. Survey Bull. 507, 309 p. 1916, Notes on some mining districts in eastern Nevada: U.S. Geol. Survey Bull. $648,214 \mathrm{p}$.

Hite, R. J., 1964, Salines, in Mineral and water resources of Utah: Utah Geol. and Mineralog. Survey Bull. 73, p. 206-215.

Hoover, T. J., 1933, The economics of mining: Stanford Univ. Press, Stanford, Calif., $547 \mathrm{p}$.

Hope, R. A., 1972, Geologic map of the Spruce Mountain quadrangle, Elko County, Nevada: U.S. Geol. Survey Geol. Quad. Map GQ-942, scale $1: 62,500$.

Horton, R. C., 1961, An inventory of fluorspar occurrences in Nevada: Nevada Bur. Mines Rept. 1, p. 24-25. 1962a, Fluorspar occurrences in Nevada: Nevada Bur. Mines Map 3. 1962b, Iron ore occurrences in Nevada: Nevada Bur. Mines Map 5. 1963, An inventory of barite occurrences in Nevada: Nevada Bur. Mines Rept. 4, 18 p. 1964a, Barite, in Mineral and water resources of Nevada: Nevada Bur. Mines Bull. 65, p. 177-180. 1964b, Hot springs, sinter deposits, and volcanic cinder cones in Nevada: Nevada Bur. Mines Map 25.

Horton, R. C., Bonham, H. F., and Longwill, W. D., 1962a, Lead occurrences in Nevada by district: Nevada Bur. Mines Map 14. 1962b, Lode gold occurrences in Nevada by district: Nevada Bur. $\because$ Mines Map 11 . 1962c, Silver occurrences in Nevada by district: Nevada Bur. Mines Map 12. 1962d, Zinc occurrences in Nevada by district: Nevada Bur. Mines Map 15.

Hose, R. K., and Taylor, B. E., 1974, Geothermal systems in northern Nevada: U.S. Geol. Survey open-file report, 27 p.

Jennings, J. D., 1953, Danger cave--a progress summary: Archeolog. Soc. New Mexico, El Palacio, v. 60, no. 5, p. 179-213.

Johnson, M. G., 1973, Placer gold deposits of Nevada: U.S. Geol. Survey Bull. 1356, 118 p. 
Ketner, K. B., 1970, Geology and mineral potential of the Adobe Range, Elko Hills, and adjacent areas, Elko County, Nevada, in Geological Survey research 1970: U.S. Geol. Survey Prof. Paper 700-B, $\therefore \quad$ p. B105-B108.

Ketner, K. B., Evans, J. G., and Hessin, T. D., 1968, Geochemical anomalies in the Swales Mountain area, Elko County, Nevada: U.S. Geol. Survey Circ. 588,13 p.

Ketner, K. B., and Smith; J. F., Jr., 1963, Geology of the Railroad mining district, Elko County, Nevada: U.S. Geol. Survey Bull. 1162-B, 27 p.

Knox, R. D., 1970, Geological and geophysical investigations of the Good Hope mining district, Elko County, Nevada: Califomia Univ., Riverside, M.S. thesis, 76 p.

Kral, V. E., 1951, Mineral resources of Nye County, Nevada: Nevada Bur. Mines Bull. 50, 220 p.

Lawrence, E. F., 1963, Antimony deposits in Nevada: Nevada Bur. Mines Bull. $61,248 \mathrm{p}$.

Lincoln, F. C., 1923, Mining districts and mineral resources of Nevada: Reno, Nevada Newsletter Publishing Co., p. 37-59.

Lintz, J. R., 1957, Nevada oil and gas drilling data, 1906-1953: Nevada Bur. Mines Bull. 52, 85 p.

Loeltz, 0. J., and Malmberg, G. T., 1961, The ground-water situation in Nevada, 1960: Nevada Dept. Conservation Nat. Resources, Groundwater Resources, Inf. Ser. Rept. 1, 20 p.

Lotz, T. A., 1934, Biennial report of Surveyor General and State Land Register for July 1, 1932-June 30, 1934: Carson City, Nev., State Printing Office, 72 p.

Lovejoy, D. W., 1959, Overthrust Ordovician and the Nannie's Peak intrusive, $\because \quad L o n e$ Mountain, Elko County, Nevada: Geol. Soc. America Bull., v. 70, no. 5, p. 539-563.

Lovering, T. S., and Stoll, W. M., 1943, Preliminary report on the Rip Van Winkle mine, Elko County, Nevada: U.S. Geol. Survey open-file report, $9 \mathrm{p}$.

Maple, W. J., and Hail, W. J., Jr., 1959, Tertiary geology of the Goose Creek district, Cassia County, Idaho, Box Elder County, Utah, and Elko County, Nevada: U.S. Geol. Survey Bull. 1055-H, p. 217-254.

McKelvey, V. E., and others, 1959, The Phosphoria, Park City, and Shedhorn Formations in the western phosphate field: U.S. Geol. Survey Prof. Paper 313-A, 47 p.

Mcknight, E. T., 1933, Mesothermal silver-lead-zinc deposits, in Ore deposits of the Western States (Lindgren volume): Am. Inst. Mining Metall. Engineers, p. 582-602. 
Morrison, R. B., 1966, Predecessors of the Great Salt Lake, in The Great Salt Lake: Utah Geol. Soc. Guidebook to the geology of Utah, no. 20 , p. 77-104.

* Morrissey, F. R., 1968, Turquoise deposits of Nevada: Nevada Bur. Mines Rept. 17, $30 \mathrm{p}$.

Murbarger, Nell, 1957, Only the sidewalks remain at Gold Creek: Desert, v. 20, no. 2, February, p. 17-22.

Nolan, T. B., 1927, Potash brines of the Great Salt Lake Desert, Utah: U.S. Geol. Survey Bull. 795, p. 25-44. 1936, The Tuscarora mining district, Elko County, Nevada: Nevada Bur. Mines, v. 30 , no. 1, $36 \mathrm{p}$.

Olson, D. R., 1960, Geology and mineralogy of the Delno mining district and vicinity, Elko County, Nevada: Utah Univ., Salt Lake City, $\mathrm{Ph}$. D. thes is, $96 \mathrm{p}$.

Olson, J. C., and Hinrichs, E. N., 1960, Beryl-bearing pegmatites in the Ruby Mountains and other areas in Nevada and northwestern Arizona: U.S. Geol. Survey Bull. 1082-D, P. 135-200.

Papke, K. G., 1970, Montmorillonite, bentonite, and fuller's earth deposits in Nevada: Nevada Bur. Mines Bull. 76, 47 p.

Pardee, J. T., and Jones, E. L., Jr., 1920, Deposits of manganese ore in Nevada: U.S. Geol. Survey Bull. 710-F, p. 209-248.

Patterson, Edna, 1964, Who named it? History of Elko County place names: Elko, Nev., Warren L. and Mary J. Monroe, Publishers, in cooperation with the Elko Independent, $92 \mathrm{p}$.

Raymond, R. W., 1869, Mineral resources of the states and territories west of the Rocky Mountains, Statistics of mines and mining, for 1868: U.S. Treasury Dept., U.S. 40th Cong., 3d sess., 256 p. 1870, Statistics of mines and mining in the states and territories

$\because$ west of the Rocky Mountains, No. 2: U.S. Treasury Dept., 4 lst Cong., $2 \mathrm{~d}$ sess., $805 \mathrm{p}$.

Roberts, R. J., Montgomery, K. M., and Lehner, R. E., 1967, Geology and mineral resources of Eureka County, Nevada: Nevada Bur. Mines Bull. $64,152 \mathrm{p}$.

Roberts, R. J., Radtke, A. S., and Coats, R. R., 1971, Gold-bearing deposits in north-central Nevada and southwestern Idaho: Econ. Geology, v. 66 , no. 1 , p. 14-33.

Rott, E. H., Jr., 1931, Ore deposits of the Gold Circle mining district, Elko County, Nevada: Nevada Univ. Bull., v. 25, no. 5, 30 p.

Rush, F. E., 1968a, Index of hydrographic areas in Nevada: Nevada Dept. Conservation Nat. Resources, Ground-water Resources, Inf. Ser. Rept. 6, 37 p. 1968b, Water-resources appraisal of Thousand Springs Valley, Elko County, Nevada: Nevada Dept. Conservation Nat. Resources, Groundwater Resources, Reconn. Ser. Rept. 47, 61 p. 
Rush, R. E., and Everett, D. E., 1966, Water-resources appraisal of the Huntington Valley area, Elko and White Pire Counties, Nevada: Nevada Dept. Conservation Nat. Resources, Water Resources, Reconn. Ser. Rept. 35, $37 \mathrm{p}$.

Schilling, J. H., 1962a, An inventory of molybdenum occurrences in Nevada: Nevada Bur. Mines Rept. 2, 48 p.

1962b, Manganese deposits in Nevada: Nevada Bur Mines Map 9. $1962 \mathrm{c}$, Molybdenum occurrences in Nevada: Nevada Bur. Mines Map 8. 1962d, Vanadium occurrences in Nevada: Nevada Bur. Mines Map 10. 1963a, Tungsten mines in Nevada: Nevada Bur. Mines Map 18. 1963b, Uranium occurrences in Nevada: Nevada Bur. Mines Map 19.

Sehilling, J. H., and Garside, L. J., 1968, Oil and gas development in Nevada, 1953-1967: Nevada Bur. Mines Rept. 18, 43 p.

Schrader, F. C., 1912, A reconnaissance of the Jarbidge, Contact, and Elk Mountain mining districts, Elko County, Nevada: U.S. Geol. Survey Bull. 497, 162 p. 1923, The Jarbidge mining district, Nevada, with a note on the Charleston district: U.S. Geol. Survey BuIl. 741, 86 p. 1931, Spruce Mountain district, Elko County, and Cherry Creek (Egan (Canyon) district, White Pine County, Nevada: Univ. Nevada Bull., v. 25 , no. $7,39 \mathrm{p}$. 1935, The Contact mining district, Nevada: U.S. Geol. Survey Bull. $847-A$, P. 1-4l.

Shawe, F. R., Reeves, R. G., and Kral, V. E., 1962, Iron ore deposits of Nevada, Part C, Iron ore deposits of northern Nevada: Nevada Bur. Mines Bull. 53, pt. C, p. 79-128.

Slack, J. F., 1972, Structure, petrology, and ore deposits of the Indian Springs (Delano Mountains) region, Elko County, Nevada: Miami Univ., Oxford, Ohio, M.S. thes is, 159 p.

Smith, A. M., 1932a, Mountain City district's mines of copper, gold, and silver: Mining Review, v. 34 (October 25, 1932), p. 6-8. 1932b, The Mountain City mining district of Nevada: Mining Jour. (Arizona), v. 16, no. 12, Nov. 30, 1932, p. 5-6. 1958, Resources report, White Pine County, Nevada: Office of Sen. George W. Malone, U.S. Senate.

Smith, A. M., and Vanderburg, W. O., 1932, Placer mining in Nevada: Nevada Univ. Bull. [18], v. 26, no. 8, 104 p.

Smith, G. H., 1943, The history of the Constock Lode 1850-1920: Nevada Bur. Mines Bull. 37, no. 3, Geology and Mining Ser. 37, 297 p.; 1966, 6th printing, $305 \mathrm{p}$. 
Smith, J. F., Jr., and Ketner, K. B., 1975, Stratigraphy of post-Paleozoic rocks and summary of resources in the Carlin-Pinyon Range area, Nevada, with a section on aeromagnetic surveys by Don R. Mabey: U.S. Geol. Survey Prof. Paper 867-B. [In press]

$\therefore$ Southern Pacific Company, 1964, Minerals for industry, vol. 1: Southern Pacific Company, $188 \mathrm{p}$.

Stretch, R. H., 1867, Annual report of the State Mineralogist of the State of Nevada for 1866: Carson City, Nev., J. E. Eckley, State Printer, $151 \mathrm{p}$.

Thompson, T. H., and West, A. A., 1881, History of Nevada: Reproduced in 1958, Berkeley, Calif., Howell-North Press, 1,000 p.

Trengove, R. R., 1959, Reconnaissance of Nevada manganese deposits: U.S. Bur. Mines Rept. Inv. 5446, 40 p.

U.S. Bureau of Mines, 1925-1932, Mineral resources of the United States, Annual volumes for 1924-1931.

1933-1973, Minerals yearbook, Annual volumes for 1932-1971.

U.S. Geological Survey, 1883-1924, Mineral resources of the United States, Annual volumes for 1882-1923.

1972, Hydrothermal alteration in northeastern Nevada [Resource investigations], in Geological Survey research 1972: U.S. Geol. Survey Prof. Paper 800-A, P. A4.

U.S. Geological Survey in collaboration with Nevada Bureau of Mines, 1964 , Mineral and water resources of Nevada: Washington, U.S. Govt.

Printing Office, 314 p. (U.S. Sen. Doc. 87, 88th Cong., 2d sess.). (Also published as Nevada Bur. Mines Bull. 65).

Vanderburg, W. 0., 1936, Placer mining in Nevada: Nevada Univ. Bull. [27], v. 30 , no. $4,1,78 \mathrm{p}$.

Waring, G. S., 1965, Thermal springs of the United States and other countries of the world: U.S. Geol. Survey Prof. Paper 492, $383 \mathrm{p}$.

Whi.te, A. F., 1869, Report of the State Mineralogist of Nevada for the years 1867 and 1868: Carson City, Nev., H. R. Mighels, State Printer, $96 \mathrm{p}$.

1871, Third biennial report of the State Mineralogist of Nevada for the years 1869 and 1870: Carson City, Nev., 128 p.

Whitehill, H. R., [1873], Biennial report of the State Mineralogist of Nevada for the years 1871 and 1872: [Carson City, Nev.], $191 \mathrm{p}$.

[1875], Biennial report of the State Mineralogist of Nevada for the years 1873 and 1874: [Carson City, Nev.], $191 \mathrm{p}$.

[1877], Biennial report of the State Mineralogist of Nevada for the years 1875 and 1876: [Carson City, Nev.], 226 p.

1879, Biennial report of the State Mineralogist of Nevada for the years 1877 and 1878: San Francisco, Calif., A. L. Bancroft E Co., 212 p. 
Wiese, J. H., 1960, The penetration chart of significant Nevada wildcats, in Guidebook to the geology of east-central Nevada: Intermountain Assoc. Petroleum Geologists 11th Ann. Field Conf., p. 232.

Winchester, D. E., 1923, Oil shale of the Rocky Mountain region: U.S. Geol. Survey Bull. 729, 204 p.

Yochelson, E. L., Fraser, G. D., 1973, Interpretation of depositional environment in the Plympton Formation (Permian), southern Pequop Mountains, Nevada, from physical stratigraphy and a faunule: U.S. Geol. Survey Jour. Research, v. 1, no. I, p. 19-32. 


\section{APPENDIX}

Explanation to Plate 1

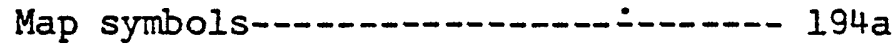

Principal mines by district-------- 194b-e

Mines, alphabetical--_-_-_-_-_--- $194 f$

Exploratory holes drilled for oil--- $194 \mathrm{~g}$ 


\section{EXPLANATION - PLATE 1}

Production

\begin{tabular}{llc}
\hline Over $\$ 100,000$ & $\begin{array}{l}\$ 5,000 \text { to } \\
\$ 100,000\end{array}$ & $\begin{array}{c}\text { Small mine or } \\
\text { prospect }\end{array}$ \\
\hline
\end{tabular}

\section{METALS}

Gold, placer

Gold, lode

Silver

Copper

Lead

Zinc

Groups of mines

Antimony

Iron

Manganese

Mercury

Tungsten

Uranium

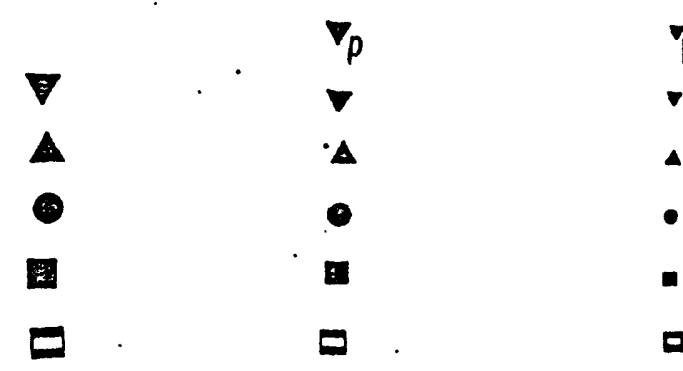

(3)

* . *

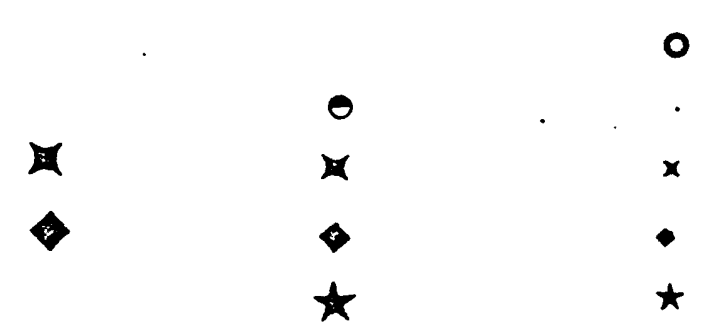

NONMETAIS

Asphaltite

Barite

Bery 1

$x_{\mathrm{Ba}}$

$x_{\mathrm{Ba}} \quad x_{\mathrm{a}}$

Clay

Coal

Diatomite

Gem stones

Gravel pits

Mica

oil shale

Phosphorite

Stone

Volcanic ash

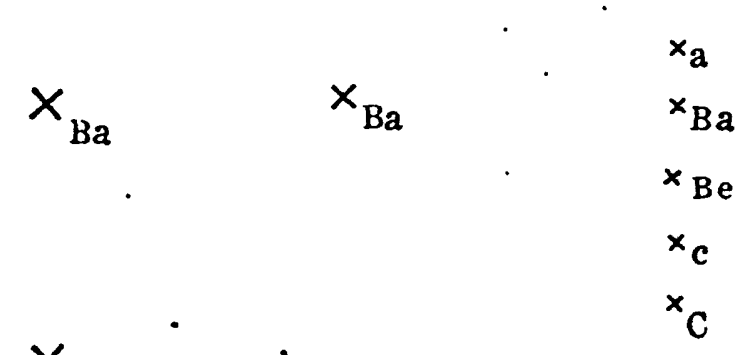

Exploratory hole drilled for oil

Show of gas

$x_{d}$

$x_{\mathrm{g}}$

Show of oil

Show of gas and oil $\Varangle$

Commodity unknown<smiles>C1CCCCC1</smiles>

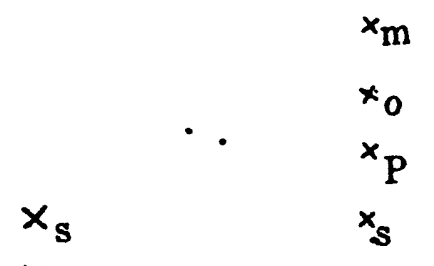


PRINCIPAL MINES BY DISTRICT

Plate 1

(Numbers correspond to those on map)

Districts indexed by Township-Range

Alder (46-56)

1. Lost Gulch placer

2. Pittsburg Silver

3. Mohawk

4. Tennessee placer

5. Knowles Bros.

6. Gamet Tungsten

Aura (44-53)

1. Blue Jacket .

2. California

3. Aura King

4. Golden Eagle

Beaver (37-52)

1. Stampede

2. Marvel (Jones Marvel)

Black Mountain (39-64)

Unnamed prospects

Bootstrap (37-49)

1. Rossi

2. Bootstrap

Burner (41-47)

Mint

Burns Basin (40-53)

1. Burns Basin

Carlin (33-52)

1. Tri-0-Lite

2. Deerhead

3. Black Kettle

Cave Creek (27-57)

Locations unknown

Charleston (44-57)

1. Batholith .

2. Virginia

3. Mcknights placer

Coal Mine (38-56)

1. Coal Canyon
Contact (45-64)

1. Boston

2. Marshall group

3. Bonanza

4. Tunnel

5. Delano

6. Copper Shield, Blanchard

7. Vulcan

8. Hice

9. Silver Star

10. Bell

Cornucopia (42-51)

Comucopia (Leopard)

Corral Creek. (28-57)

1. Summit View

Decoy (32-69)

Darkey, Black Rock

Delano (44-68)

1. Delno

2. Cleveland.

3. Gold Note

4. Mitchell

5. Indian Springs

Delker $\left(29^{\circ}-62\right)$

Delker

Divide (40-50)

Divide

Dolly Varden (28-66)

1. Mizpah

- 2. Victoria

3. Dolly Varden

Edgemont (4:4-52)

1. Nevada

2. Burns

3. Lucky Girl

4.. Bull Run 
- Principal mines by district--Continued

Elk Mountain.(46-61)

1. Red Elephant prospect

2. Gold prospect

3. Estes prospect

4. Robinette prospect

Elko (34-55)

1. Catlin

2. Norton

3. Conglomerate quarry Phosphate prospects

Ferber (2.7-70)

1. Regent

2. Martha Washington

Ferguson Spring (30-69)

1. Dead Cedar

Gilbert Canyon (29-57)

1. Pegmatitè

2. Pegmatite

Gold Basin (47-56)

1. Deep Creek

2. Bruneau

3. Mendive

Gold Circle (39-46)

1. Elko Prince

2. Gold Circle

3. Rex

4. Missing Link

5. Jackson

6. Eastern Star

7. Esmeralda

Good Hope (41-49)

1. Amazon

2. Good Hope

3. Buckeye and Ohio

Goose Creek (47-69).

Lignite, stone-Twin Falls County, Idaho

Halleck (35-59)

Gold-location unknown
Harrison Pass (28-58)

1. Lakeview

2. Star

Hicks (46-55)

1. Silver King

2. McDonald

Hot Creek (39-59)

Unknown

- Huntingtón Creek (31-56)

1. Mineral Soap

Island Mountain (44-55)

1. Little Joe

2. Star Metal

3. Gribble

4. Diamond Jim

5. St. Elmo

6. Penrod

7. Coleman

8. MCGregor

Ivanhoe (38-47)

1. Rimrock

2. Sheep Corral

3. Governor-Ivanhoe

4. Fox

5. Butte

6. Velvet

7. Old Timers

8. Clementine

9. Silver Cloud

Jarbidge (46-58)

1. Blizzard

2. Long Hike

3. Success

4. Bluster

5. Rex

- 6. Coon Creek

7. Norman

8. Wildeat 
Principal mines by district--Continued

Kinsley (26-67)

1. Captain Jack

2. Southam

3. Western

4. Moming Star

5. Doty Tunnel

Lafayette (35-64)

Copper prospects

Larrabee (28-53)

1. Unnamed barite

Lee $(30-58)$

1. American Beauty

2. Long Canyon

3. Hargrove

Lime Mountain (42-51)

1. Lime Mountain

Loray (37-68)

1. Cobrecite

2. Castle Park

Lucin (39-70)

1. Black Warrior

2. Tecoma

Merrimac (37-53)

1. Lone Wolf

2. Rip Van Winkle

3. Iron Hood

Montello (39-68)

Phosphate prospects

Moor (37-68)

1. Limestone

2. Iron prospect

Mountain City (46-54)

1. Protection

2. Independence

3. Resurrection

4. Soft Snap

5. Racetrack

6. Golden Ensign

7. Mountain City Mercur

8. Rio Tinto

9. Morrison-Knudsen
Mud Springs (28-60)

I. Silver Butte

Pequop (31-65)

Phosphate prospects

Pilot Peak (36-70)

1. Badger

2. Crazy Dutchman

Proctor (35-68)

1. Hice prospect

2. Rare Metals

3. Pilot quarry

Railroad (30-53)

1. Pine Mountain

2. Copper Bell

3. Aladdin, Delmas, NevadaBunker Hill, Standing Elk, Sylvania, Tripoli, Webfoot

4. Grey Eagle

Robinson Mountain (29-53)

1. Asphaltite

2. Unnamed barite

Rock Creek (30-49)

1. Falcon

2. Rock Creek

Ruby Valley (30-59)

1. Michigan

2. Battle Creek group

Spruce Mountain (31-63)

1. Spruce Standard

2. Monarch

3. Nevada Lead

4. Copper Queen

5. Black. Forest

Swales Mountain (35-53)

1. Barite prospects

2. Gold prospects

Tecoma (41-70)

1. Jackson 
Principal mines by district--Continued

Tuscarora- (40-51)

1. Silverado

2. Belle Isle, Commonwealth, Navajo, Nevada Queen, $\mathrm{N}$. Belle Isle, N. Commonwealth

3. Argenta, Defrees, Grand Prize, Independence

4. Dexter

5. Placer deposits

6. Berry Creek

Union (26-53)

1. Bell

Valley View (29-58)

1. Errington and Thiel

2. Valley View

Warm Creek (33-61)

1. Silver Cliff

2. Polar Star

Wells $(37-62)$

1. Nevada Picture Rock

2. Unknown tungsten

Wendover $(33-70)$

1. Unnamed stone quarry

White Horse $(28-68)$

1. Epidote claim 
|

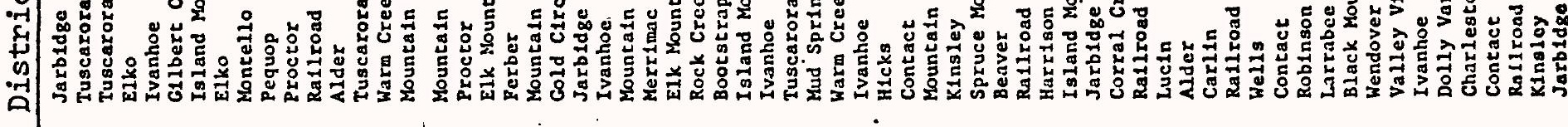

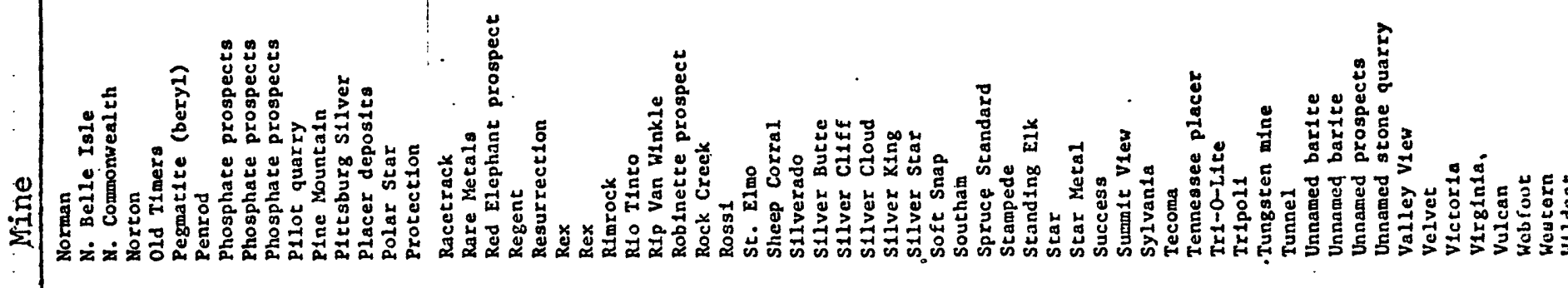
| 密

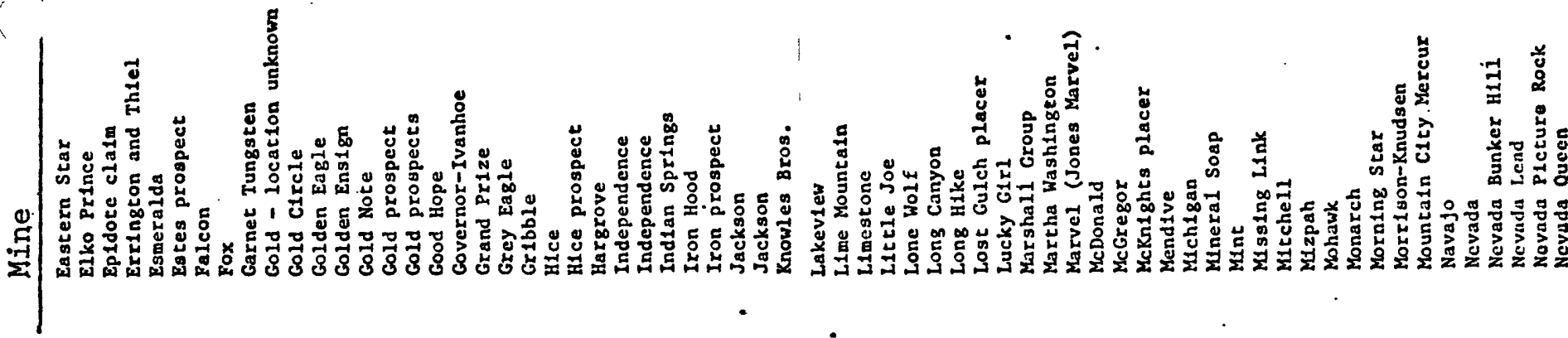

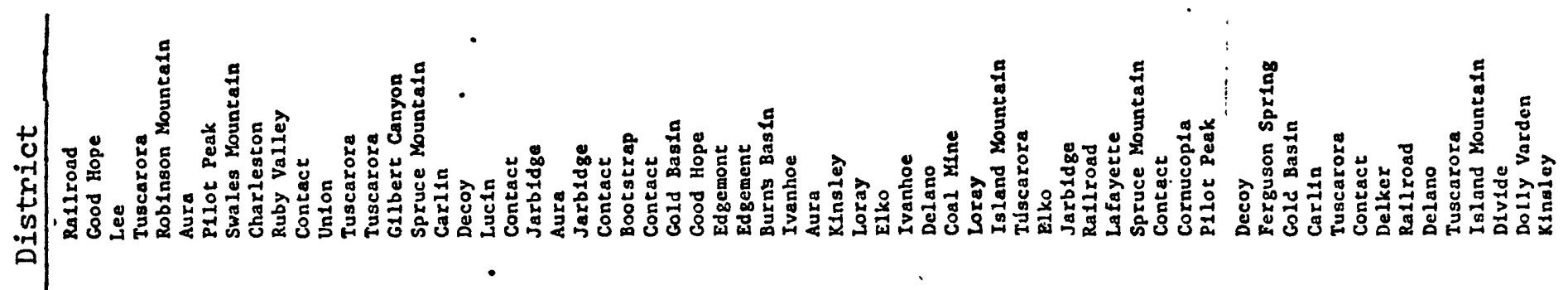

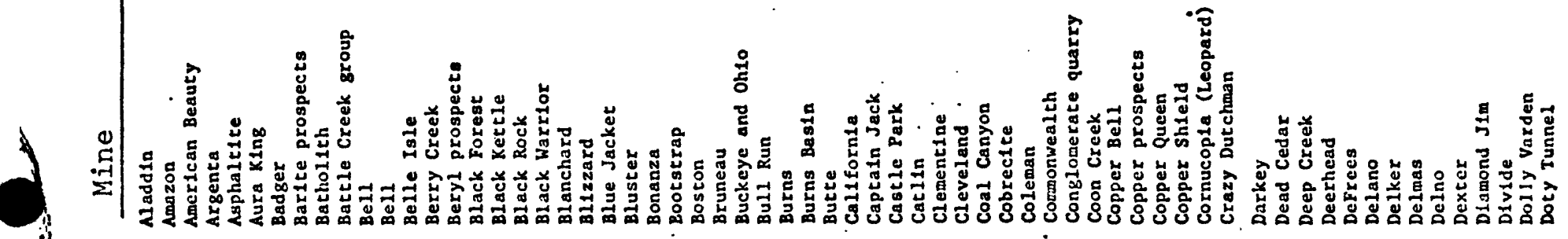


EXPLORATORY HOLES DRILLED FOR OIL

Listed by Township-Range-, MDBM

Index No.

Company, Unit, Hole No.

T. R.

N. E.

Bul1 Run $0: 1$ and Gas Co. No. 1

$43 \quad 52$

Richfield Oil Corp. Scott-Ogilvie No. 1

$43 \quad 52$

Gulf Refining Co. Mary's River Federal No. 1

4160

Gulf Refining Co. Thousand Springs No. 1

$40 \quad 66$

Gulf Refining Co. Wilkins Ranch No. 2

$39 \quad 69$

Gulf Refining Co. Wilkins Ranch No. 1

$38 \quad 61$

Atlantic International Oil Corp. Dalton No. 1

62

Gulf Refining Co. Pete Itcaina No..1

$37 \quad 59$

Inland $0 i 1$ Co. Itcaina No. 1

$36 \quad 58$

Inland 011 Co. Itcaina No. 2

$36 \quad 58$

Inland $0 i l$ Co. Itcaina No. 3

$36 \quad 58$

Merritt Armstrong

$35 \quad 55$

Dr. Eby's Well

$35 \quad 56$

McCarthy 0i1 Co: Rahas No.1

$35 \quad 58$

Elko Oil Development \& Improvement Co. No. 1 (John Brown Wel1)

Richfield Oil Corp. Rabbit Creek No. 1

Gulf Oil Corp. of California Owl Hill Federal No. 1

Diamond Oil Co. Diamond Valley No. 1 